UNIVERSIDADE DE SÃO PAULO

FACULDADE DE FILOSOFIA, LETRAS E CIÊNCIAS HUMANAS DEPARTAMENTO DE ANTROPOLOGIA

PROGRAMA DE PÓS-GRADUAÇÃO EM ANTROPOLOGIA SOCIAL

CECÍLIA DE SANTARÉM AZEVEDO DE OLIVEIRA

Fios e Tramas de Miçangas - Tecendo relações na Guiana Indígena

Versão Corrigida

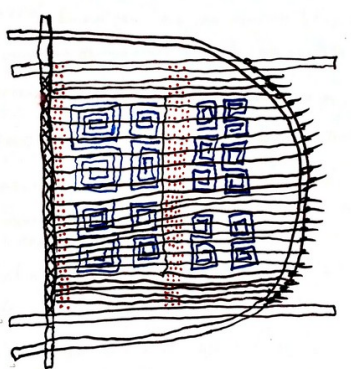

São Paulo

2019 


\author{
Universidade de São Paulo \\ Faculdade de Filosofia, Letras e Ciências Humanas \\ Departamento de Antropologia \\ Programa de Pós-Graduação em Antropologia Social
}

\title{
Fios e Tramas de Miçangas - Tecendo relações na Guiana Indígena
}

\author{
Versão corrigida
}

Cecília de Santarém Azevedo de Oliveira

Dissertação de mestrado apresentada ao Departamento de Antropologia Social do Departamento de Antropologia da Faculdade de Filosofia, Letras e Ciências Humanas da Universidade de São Paulo, para a obtenção do título de mestra em Antropologia Social

Orientadora: Dominique Tilkin Gallois

São Paulo 
Autorizo a reprodução e divulgação total ou parcial deste trabalho, por qualquer meio convencional ou eletrônico, para fins de estudo e pesquisa, desde que citada a fonte.

Catalogação na Publicação

Serviço de Biblioteca e Documentação

Faculdade de Filosofia, Letras e Ciências Humanas da Universidade de São Paulo

$048 f$

Oliveira, Cecília de Santarém Azevedo de

Fios e Tramas de Miçangas - Tecendo relações na

Guiana Indígena / Cecília de Santarém Azevedo de

Oliveira ; orientadora Dominique Tilkin Gallois. -

São Paulo, 2019.

$165 \mathrm{f}$.

Dissertação (Mestrado) - Faculdade de Filosofia, Letras e Ciências Humanas da Universidade de São Paulo. Departamento de Antropologia. Área de concentração: Antropologia Social.

1. CULTURA MATERIAL. 2. CORPORALIDADE. 3. GUIANENSES. 4. TIRIYÓ. I. Gallois, Dominique Tilkin, orient. II. Título. 


\title{
ENTREGA DO EXEMPLAR CORRIGIDO DA DISSERTAÇÃO/TESE
}

Termo de Ciência e Concordância do (a) orientador (a)

\author{
Nome do (a) aluno (a): CECÍLIA DE SANTARÉM AZEVEDo DE OLIVEIRA \\ Data da defesa: 18/DEZ/2019
}

Nome do Prof. (a) orientador (a): DOMINIQUE TILKIN GALLOIS

Nos termos da legislação vigente, declaro ESTAR CIENTE do conteúdo deste EXEMPLAR CORRIGIDO elaborado em atenção às sugestões dos membros da comissão Julgadora na sessão de defesa do trabalho, manifestando-me plenamente favorável ao seu encaminhamento e publicação no Portal Digital de Teses da USP.

São Paulo, 15 de abril de 2020

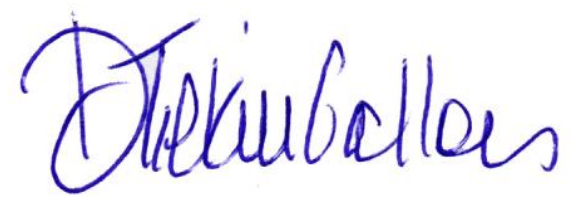


Nome: OLIVEIRA, Cecília de Santarém Azevedo de

Título: Fios e Tramas de Miçangas - Tecendo Relações na Guiana Indígena

Dissertação apresentada à Faculdade de Filosofia, Letras e Ciências Humanas da Universidade de São Paulo para obtenção do título de mestra em ciências.

Aprovada em: 18 de dezembro de 2019

\section{Banca examinadora}

Profa. Dra. Dominique Tilkin Gallois (orientadora)

Instituição: Antropologia/FFLCH/USP

Dra. Ana Marta Tie Yano

Instituição: (Externa)

Julgamento: APROVADA

Dra. Maria Denise Fajardo Pereira

Instituição: (Externa/Iepé)

Julgamento: APROVADA

Profa. Dra. Lúcia Hussak van Velthem

Instituição: Museu Paraense Emilio Goeldi

Julgamento: APROVADA 
A todas as mulheres, que seguem compondo corpos em fios e tramas, apesar das tensões e dos nós

Ao meu pai, Magnólio de Oliveira, com toda alegria e seriedade À minha mãe, Gorda Azevedo, e meus irmãos, Lígia de Gaia e Antônio Felipe 


\title{
Resumo
}

As peças feitas de miçangas estão presentes em muitas descrições etnográficas referentes aos povos indígenas das Guianas. Desde os primeiros relatos de viajantes europeus até os mais recentes projetos de valorização do patrimônio imaterial, confirma-se o enorme interesse desses povos pelas miçangas, que delas fazem múltiplos usos. Atravessando grandes distâncias tanto sob a forma de fios de contas quanto sob a de tramas tecidas com variados padrões iconográficos, as miçangas também são objetos significativos nas mitologias da região. A partir de revisão bibliográfica e de trabalho de campo na TI Parque do Tumucumaque - norte do Pará, esta pesquisa aborda as múltiplas formas de utilização das miçangas bem como as transformações que tanto as contas como os objetos feitos com elas operam.

Palavras-chave: miçangas, corporalidade, redes, Tiriyó, Guianas.

\begin{abstract}
Objects made of beads are present in many Guyanese ethnographic descriptions. From the first reports of European travelers to the latest intangible heritage enhancement projects, the people of this region are frankly interested in glass beads and make multiple uses of them . Crossing great distances in the form of both bead strings and wefts with varying iconographic patterns, beads are also significant objects in the mythologies of the region. This research exposes multiple ways of using beads as well as the transformations that both the beads and the objects made with them take place, based on a review of available literature and fieldwork at TI Parque do Tumucumaque (northern Pará).
\end{abstract}

Key-words: Beads, Bodily Practices, Networks, Tiriyó, Guianas 
Uma conta não faz colar

Duas contas, o que é que dá?

Três já dá pra enfeitar

Quatro, então, faz melhorar

Cinco é mistério a decifrar

Seis, quando junta, fica lindo

Eu e ela e ele

e tu e nós e tudo

(Trecho de Rosário de Contas, de Tita Reis) 


\section{AGRADECIMENTOS}

A todas as pessoas tão queridas que não me fizeram desistir depois de tantas tentativas frustradas de passar na seleção do mestrado. E a todas aquelas que seguiram apoiando, de perto e de longe, esse processo tão intenso. ${ }^{1}$

Ao Carimbó!! Flor de Jambu, Ykamiabas e tantas outras pessoas maravilhosas que trazem tanta energia para vida. Carimbó é tradição e resistência!!

Ao Circo, alegria e seriedade, que nunca nos falte, e que sempre possamos espalhar por onde formos.

Ao Sítio do Sobrado e todas as pessoas que insistem nas possibilidades desse mundo.

À gentil equipe do Iepé, em especial do Programa Tumucumaque.

Às boas surpresas do PPGAS, entre motins e brados de felicidade.

À recepção no Museu Paraense Emílio Goeldi (espero que apenas o ínicio de uma relação).

À minha família, tão querida e tão encorajadora, entre pilhas de caixas de miçangas e outras bagunças - a maior sorte dessa vida é ter nascido aqui.

À Dominique Tilkin Gallois, a quem admiro profundamente em muitos âmbitos dessa vida, agradecimentos enormes pela orientação, pelo apoio, pelo carinho.

À Denise Fajardo, por ser tão difícil imaginar como seria a vida sem ter chegado até o Tumucumaque sendo Denise ipëeto. Como orientadora de iniciação científica, como

1 Ilan Lapyda, Augusto Ventura dos Santos, Gorda, Magnólio, Lígia de Gaia, Felipe Pin, Denise Fajardo, Dominique Gallois, Juliana Rosalen, Priscila Matta, Ana Yano, Nick Ananas Lapointe, Ana Bia Brandão, Maurílio Gorgolione, Julia Affonso, Victoria Porpino, Mari Cris, Maria Clara, Thais Maciota, Bianca Casseb, Noubar Sarkissian Jr., Ruth Takiya, Edu Paiva, Camila de Sá, Gabriel Hernandes, Carol Tucuju, Priscila Tapajora, Luana Tapajós, Gabi Sena, Aline Lola, Danielle Alves de Sousa, Rudá Nóbrega, Giordanna Souza, Anna Pujol, Alice Haibara, Anita Moreira, Carol Penteado, Iara Caldeira do Amaral, Rafael Steban Leão, Frã Donatti, Anita e Elisa Nejme, Marina Rabelo, Aline Aquino, Eduardo Gonçalves, Morgane Avery, André Lopes, Karenina Calarga, Barbara Pereira Pedro, Luiz Storni, Cristina Pietraroia, Maria Ester Massola, Luizan Tamaruteua Pinheiro, Frank Nabeta, Lucas Ramiro, Juciele Borges, Andréia Vaz, Thomas Gallois, Marina Minari, Evandro Bernardi, Renan Reis, Diogo, Jeciane Fonseca, Leonardo Viana Braga, Luísa Girardi, Stelio Marras, José Guilherme Magnani, Aventino Nakai, Lurdes Kaxuyana, Cecília Awaeko, Arawaje Wayana Aparai, Jacilene Parena, Angela Kaxuyana, Soraia Chung, Suane Brazão, Mestre Ivamas dos Santos, Ereu Apalai, Jeanne Sia Wayana Tiriyó, Guadalupe e Peti Tiriyó, Adão Kaxuyana e Gisele Tiriyó, Lupércio Masumasu, Nazaré Tiriyó, Juventino Kaxuyana, Rosa Kawaru, Manuel Moí Tihta, Mário Kaxuyana, Kara Tiriyó, Ivanilce Kaxuyana, Joaquim Almeida Sabão, Paulinha Gonçalves, Caio Mader, Paula Bessa, Eduardo Sierra, Moisés Lameira, Renato Sztutman, Bia Perrone, Leila Lapyda, René Lapyda, Nelise Carbonare, e tantas outras pessoas tão gentis que me deram tanta força e se permitiram encantar pelas miçangas do Tumucumaque. 
coordenadora no Programa Tumucumaque/Iepé, como banca de qualificação e banca de mestrado, como amiga e mulher de muita fibra - os agradecimentos nunca faltarão.

À Lúcia van Velthem, que primeiro conheci por bibliografia, depois tive a honra de conhecer pessoalmente, e contar com importantes contribuições na qualificação e na defesa, além da inesquecível recepção em Belém e no Museu Paraense Emílio Goeldi.

À Ana Yano, desde o primeiro semestre de graduação até a banca do mestrado, amiga pela qual nutro profunda admiração enquanto pessoa e enquanto antropóloga, sempre singela e precisa.

A todas as melhores pessoas que pude conhecer nos rios Paru de Leste, Paru de Oeste, Marapi, Cachorro, Trombetas, Mapuera, Nhamundá, Jatapu e Jatapuzinho. Cada desafio vale a pena para continuar ao lado dos povos indígenas, nas lutas, nos aprendizados, na samura e, é claro, na sakura!

Okê Arô! 


\section{Índice}

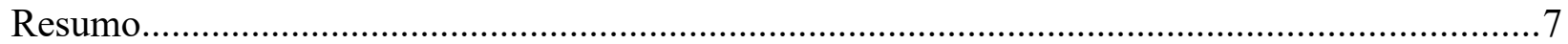

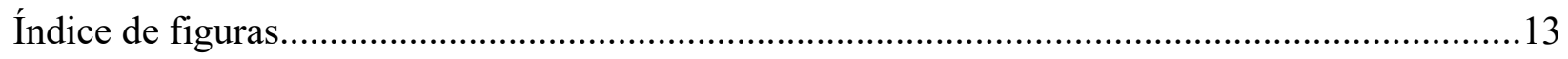

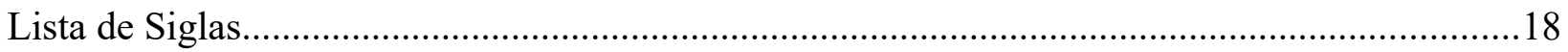

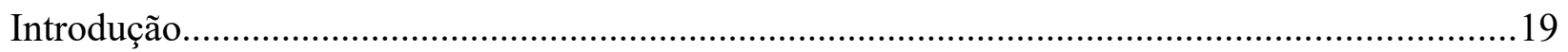

Enlaces iniciais: aproximações ao tema da pesquisa......................................................21

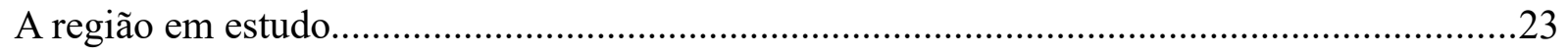

Condições de pesquisa e realização de trabalho de campo..................................................27

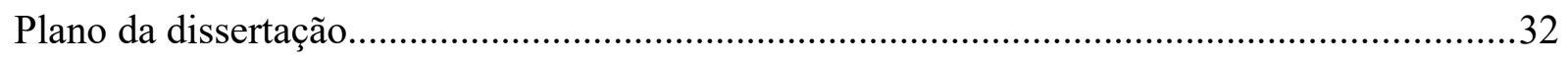

Capítulo 1: De onde vem as miçangas? Apropriações ameríndias............................................35

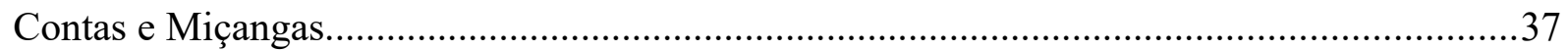

Miçangas e outras contas na América Indígena...........................................................42

América do Norte: wampum e quillwork ...................................................................45

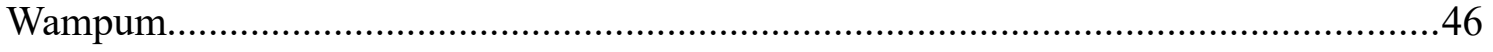

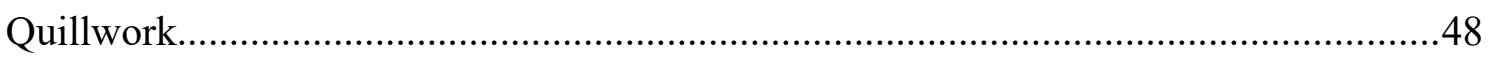

Miçangas e Povos Indígenas nas Terras Baixas da América do Sul.................................51

Apropriação e circulação das miçangas na Guiana Indígena...........................................54

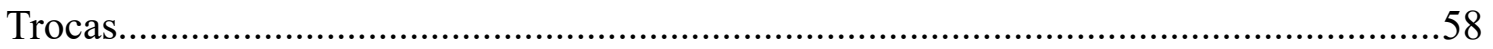

Circulações contemporâneas das miçangas...............................................................64

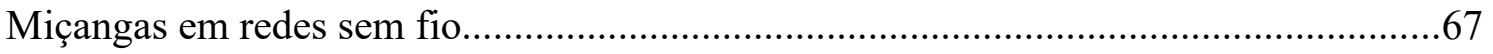

Capítulo 2: Samura Rïtohton - Assim que tecemos miçangas....................................................71

Pakaratao, patupisi marë - dentro dos recipientes.........................................................74

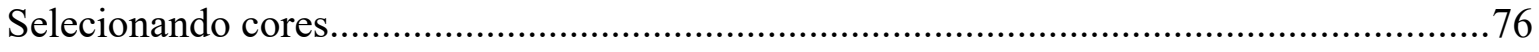

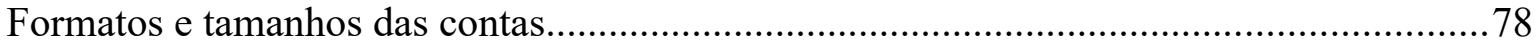

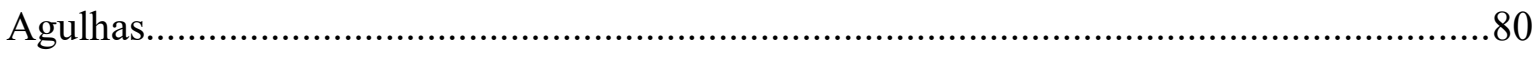

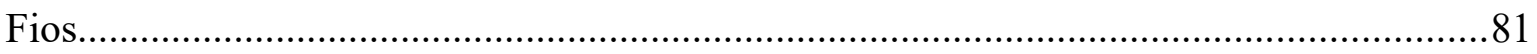

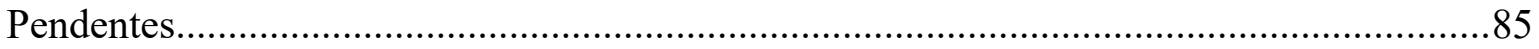

Samura Rïtohton - Assim tecemos miçangas............................................................... 86 


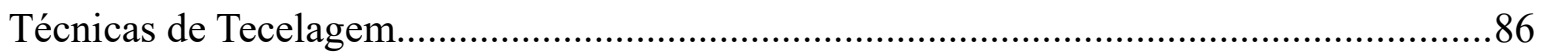

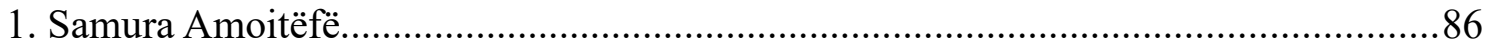

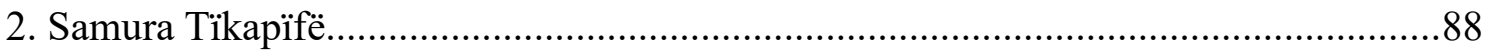

Padrões gráficos em circulação..................................................................................94

Controvérsias na patrimonialização de saberes em rede..................................................98

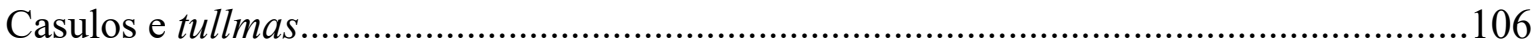

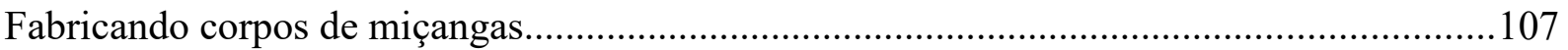

O traje tradicional karib e suas variações........................................................................110

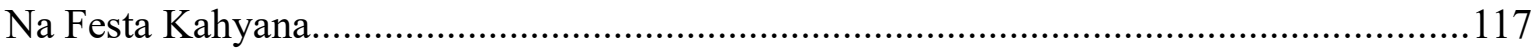

Capítulo 3. Corpos políticos em ações: miçangas e algodão entre festas e guerras.....................122

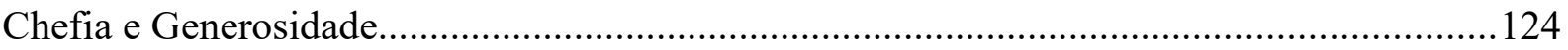

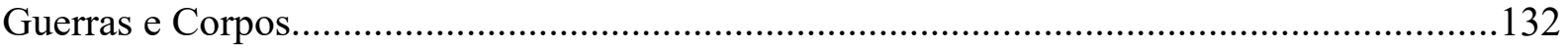

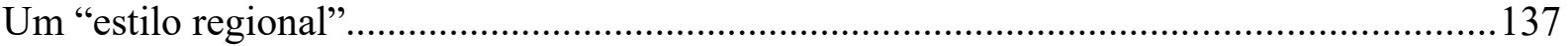

Miçangas em cantos: a relação pawana ………………………………………………….....139

O corpo enfeitado do pïyai..........................................................................................141

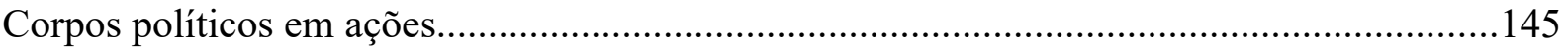

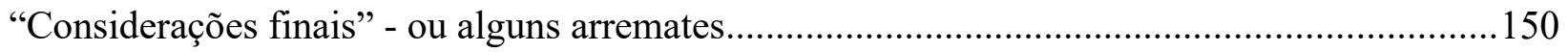

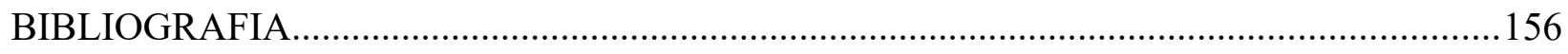




\section{Índice de figuras}

As imagens apresentadas, em sua maior parte, são de minha autoria. Aquelas que não o são, tem sua fonte indicada na legenda.

Figura 1: Mapa da região, com destaque para as Terras Indígenas e rios, elaborado por Thomas Gallois .26

Figura 2: Início do keweyu que Lurdes Kaxuyana estava me ensinando a tecer. Fevereiro de 2019 .

Figura 3: Frente e verso do mostruário de miçangas provenientes da República Tcheca, ou "samura ikuhtu", como chamado em língua tiriyó.

Figura 4: Vochol, o fusca recoberto de miçangas por oito artistas huitchol, quando exibido em Paris, 2012. Imagem acessada em: By Palamède - Own work, CC BY-SA 4.0, https://commons.wikimedia.org/w/index.php?curid=41639089. [Acesso em 30 de setembro de 2019]

Figura 5: Detalhe de cinto wampum, datado do meio do séc. XVIII, apresentando uma única miçanga de vidro em meio à sua trama. Penn Museum (Filadélfia). Foto de Lise Puyo. Fonte: https://www.penn.museum/blog/museum/wampum-research-notes-from-the-trail-june-2015/

[Acesso em 01 de outubro de 2019]. .48

Figura 6: Par de mocassins Haudenosaunee ou Wyandot, datado de meados de 1780. Pele de cervo, espinhos de porco-espinho, miçangas cilíndricas, couro, metal, entrecasca de carvalho, tecido. Coleção do Musée du Quai Branly, n. de inventário: 71.1909.19.61.1-2 Am D. http://www.quaibranly.fr/fr/explorer-les-collections/base/Work/action/show/notice/314379-pairede-mocassins/page/1/ [Acesso em 01 de outubro de 2019]

Figura 7: O rapper crow Supaman apresenta-se sempre com suas roupas de Regalia, com detalhes em miçangas no adereço de cabeça, nas mangas, no peito. Fonte: https://www.powwows.com/supamans-fans-know-his-passion-for-music-but-he-has-anotherpassion-powwows/ [Acesso em 01 de outubro de 2019]. .50

Figura 8: "Couyou" e "Camiza". Fonte: La Mousse \& Collomb 2006. .55

Figura 9: Catarina Tiriyó nos mostra o keweyu que fez. Aldeia Missão Tiriyó, abril de 2019....56 
Figura 10: Casa Galibi, com diversos objetos, incluindo uma tanga, possivelmente feita de miçangas, ao lado esquerdo da rede. Crevaux 1883:12. Disponível em: https://archive.org/details/ voyagesdanslam00crevuoft/page/11 [Acesso 01 de outubro de 2019].

Figura 11: Mapas que mostram a situação pré-concentração nos aldeamentos missionários no Brasil e no Suriname. Frikel 1971: 37, 39, 42. Disponível em: https://repositorio.museugoeldi.br/handle/mgoeldi/895 [Acesso 01 de outubro de 2019]. .60

Figura 12: Fluxo de cães entre meados dos séculos XVIII e XIX. Barbosa 2007:87.

Figura 13: Frame do videoclipe dos rappers Embera Linaje Originarios (Colombia). Disponível em https://www.youtube.com/watch?v=FvYj0XAuTVE. [Acesso 30 de setembro de 2019] .....70 Figura 14: Jovens Wayana preparam-se para uma festa. Aldeia Xuixuimene, TI Rio Paru d'Este, abril de 2019

Figura 15: Bandoleiras (iyafan) de Matias Ape Tiriyó, falecido em 2018, guardadas por sua nora Lurdes Kaxuyana...... .73

Figura 16: Pedaço de panti, cinto masculino, que pertencera ao marido de Lurdes, Tito Meri Tiriyó, donde ela agora copia padrões gráficos para os cintos de seus filhos... .73

Figura 17: Xipatai Apalai indica a proveniência das diferentes miçangas (as brancas vieram da Guiana Francesa) que utilizou na feitura de seus weju; Xipatai prefere utilizar miçangas tamanho 6/0, chamadas kahuru tepu (wayana) ou kasuru topu (aparai).

Figura 18: Cinto encontrado na coleção do MPEG, sob $n^{0}$ de identificação 7431. Observa-se diferentes tipos de linha em sua composição.

Figura 19: Detalhe de tanga encontrada na coleção do MPEG, onde além dos diferentes tipos de linha, percebe-se que já havia a circulação de miçangas com tamanho bem inferior ao tamanho 9/0 (corpo da tanga) .83

Figura 20: Criança colocando iyafan. Aldeia Santo Antonio, 2010. Acervo Iepé. .87

Figura 21: Lurdes Kaxuyana me explica sobre cores das miçangas, antes de começar a armar o keweyu em seu tear. A armação mais clara, à direita, é do keweyu que ela me ensinaria a tecer. A outra, com um keweyu em processo de feitura, ela está fazendo para sua filha. Foto de Jacilene Parena Kaxuyana Tiriyó. Janeiro de 2019. .88

Figura 22: Keweyu em sua armação, no acervo do Museu Paraense Emilio Goeldi (identificação: 9381). Junho de 2019. 
Figura 23: Tecendo um cinto. aldeia Santo Antonio, março de 2017 ............................................90

Figura 24: Pulseira sendo preparada em seu tear. Aldeia Missão Tiriyó, janeiro de 2019............91

Figura 25: Pulseira tecida por Isabela Naya Tiriyó Kaxuyana. Padrão gráfico: tuna rere.............92

Figura 26: Detalhe de colar sendo tecido por Rosineide Saripun Kaxuyana Tiriyó. Foto: Rosineide Saripun Kaxuyana Tiriyó

Figura 27: Pulseira tecida por Arawaje Wayana Aparai, a partir de motivos que ela conheceu em viagem ao Acre (Encontro de Mulheres Indígenas). Agosto de 2017.

Figura 28: Padrão wajãpi denominado urupe aravekwa (ânus da peneira). Autor: Karaviju Wajãpi. IPHAN 2000:53.

Figura 29: Padrão conhecido em língua wayana como kuri putpë, e em língua aparai como kuriru pitpure (caso de jabuti/ente sobrenatural). Velthem 1998:150

Figura 30: Verso de bolsa tecida em miçangas por Isabela Naya Tiriyó Kaxuyana (2017), com o padrão conhecido em língua tiriyó como taripi enu (olho de macaco) .96

Figura 31: Pulseira com o padrão aparai imenu (desenho dos Aparai), feita por Rosineide Saripun Kaxuyana Tiriyó e por mim. Aldeia Santo Antônio, 2014.

Figura 32: Keweyu tiriyó, com o padrão pakara imenu (desenho de cesto), disponível no Stichting Surinaams Museum. Coletado em 1991. Disponível em http://amazonian-museumnetwork.org/en/ssm-0047?from=search [Acesso em 07 de outubro de 2019]. .100

Figura 33: Keweyu tiriyó (acervo MPEG, $\mathrm{n}^{\circ}$ 11290), com padrão arimi aroki (rabo de macaco coamba). Coletado em 1965

Figura 34: Salomé Takëfë Tiriyó nos mostra keweyu feito por ela com o padrão kaikui ipana (orelha de onça). Abril de 2019.

Figura 35: Weju feito por Xipatai Apalai, com grafismo kaikuxi (onça sobrenatural). 2019.....102

Figura 36: Pulseira tiriyó, localizada no Museu Paranense Emilio Goeldi, sob a identificação 7416. 103

Figura 37: Pulseiras de miçangas por Lorena Ikunau Tiriyó, com imagens figurativas de helicóptero e papagaio. (2017) 104

Figura 38: Verso das pulseiras apresentadas na figura anterior, contendo meu nome e meu apelido 104 
Figura 40: Adriana Tawaya Kaxuyana, mostrando o modo adequado de se usar as tullmas enquanto colar de jakëmi (casulo). Aldeia Santo Antônio, 2015. .108

Figura 41: Da esquerda para direita: tullma boliviana original, proveniente do Salar do Uyuni; réplica (problemática) feita por mim; colar jakëmi, feito pelas mulheres da aldeia Santo Antonio, entre 2016 e 2017. 108

Figura 42: Traje tradicional de mulher kahyana, conforme informado por Maria Vieira Kahyana.

Figura 43: Mulher tarëno (provavelmente Aramiso), participando de uma missa. Final da década 1960/ Início dos anos 1970. Acervo Denise Fajardo. 113

Figura 44: Esquema para identificação do traje tradicional tarëno, conforme tabela abaixo.....113

Figura 45: Homem tarëno. Observa-se o uso do adorno de quadril chamado em língua tiriyó okunxoro (Frikel 1973), além de um penacho alçado de braçadeira (cf. Ribeiro 1988), diadema de plumária, plumas no cabelo, e tanga masculina kamisa. Acervo Denise Fajardo. 114

Figura 46: Detalhe da ornamentação do mesmo homem da imagem anteior, destacando a profusão de miçangas. Acervo Denise Fajardo.

Figura 47: Ilustrações do traje tradicional feminino aparai, produzidas por mulheres wayana e aparai. Dezembro de 2018.

Figura 48: Ilustração do traje tradicional aparai masculino, produzida por mulheres wayana e aparai. Dezembro de 2018. 116

Figura 49: Homens e mulher wajãpi dançam durante a Festa do Pacu. Foto: Mário Vilella. Disponível em: https://www.institutoiepe.org.br/programas/programa-wajapi/ [Acesso em 07 de outubro de 2019].

Figura 50: Mário Kaxuyana (à esquerda) observa fotos dos antigos Kahyana, enquanto Kanahtxe (de vermelho) argumenta para Juventino e Ângela Kaxuyana (à direita) que o traje vermelho seria tradicional dos Wajãpi e não dos Kahyana, conforme mostra a capa do Protocolo de Consulta e Consentimento dos Wajãpis, que está na mão de Juventino. Aldeia Araçá. Junho de 2018 . 121

Figura 51: Conjunto de toposiwa, como apresentado em Grupioni 2002:46.........................126

Figura 52: Guadalupe e Peti Tiriyó, aldeia Oroientu. Fevereiro de 2019................................134

Figura 53: Ilustração de um pïyai (Crevaux 1883)..... 143 
Figura 54: Miçangas na perna de uma bebê e keweyu. Aldeia Pedra da Onça. Março 2017.....155 


\section{Lista de Siglas}

AIKATUK - Associação Indígena Katxuyana, Tunayana e Kahyana

AMITIKATXI - Articulação das Mulheres Indígenas Tiriyó, Katxuyana e Txikiyana

ANAC - Agência Nacional de Aviação Civil

APITIKATXI - Associação dos Povos Indígenas Tiriyó, Katxuyana e Txikiyana

APIW - Associação dos Povos Indígenas Wai Wai

APIWA - Associação dos Povos Indígenas Wayana e Aparai

CASAI - Casa de Saúde Indígena

CGETNO - Coordenação Geral de Promoção ao Etnodesenvolvimento

FAB - Força Aérea Brasileira

FLOTA - Floresta Estadual

IBAMA - Instituto Brasileiro do Meio Ambiente e dos Recursos Naturais Renováveis

ICMBio - Instituto Chico Mendes de Conservação da Biodiversidade

Ideflor-Bio - Instituto de Desenvolvimento Florestal e da Biodiversidade do Estado do Pará

Iepé - Instituto de Pesquisa e Formação Indígena

IPHAN - Instituto do Patrimônio Histórico e Artístico Nacional

MCH - Mini Central Hidrelétrica

MPF - Ministério Público Federal

OIT - Organização Internacional do Trabalho

ONU - Organizações das Nações Unidas

PGTA - Plano de Gestão Territorial e Ambiental

T.I. - Terra Indígena 
Introdução 
Cecília Awaeko Apalai mexia no seu colar de várias voltas de miçangas amarelas $\mathrm{n}^{\circ}$ 12/0 ao mesmo tempo em que explicava para mim e para Érika Yamada, advogada e Perita da ONU no Mecanismo sobre Direitos dos Povos Indígenas, os desafios da presidência de uma associação, seja no trato com caciques e comunidades, seja nas relações com os nãoindígenas. Experiente liderança indígena, à frente da APIWA - Associação dos Povos Indígenas Wayana e Aparai há muitos anos, Cecília é não só uma liderança muito respeitada como uma artesã muito habilidosa. Sua frase foi categórica: "Quem está no poder? O conjunto!".

Pode parecer inusitado que uma pesquisa a respeito de apropriações e usos de miçangas entre povos indígenas se inicie com uma cena que trata de política. Pretendo, ao longo dos capítulos que seguem, tornar evidente as relações existentes entre as qualidades sensíveis das miçangas (beleza, abundância, diferentes cores, durabilidade) e dos outros materiais que as acompanham (especialmente os fios e sua perecibilidade) e os modos como os povos indígenas do sudeste guianense fabricam corpos belos, adequados e políticos, isto é, aptos a se relacionarem com outros seres, humanos ou não.

Mais do que fornecer uma imagem inesperada a respeito da chefia guianense, as miçangas aparecem cotidianamente nas diferentes aldeias de toda região. Crianças bem pequenas já têm suas pernas enfeitadas com miçangas, na forma de fios ou de finas tramas, amarrados abaixo do joelho e acima do tornozelo. As moças usam gargantilhas com diversos tipos de pendentes ornamentando seus pescoços: letras, pássaros, flores, tramados em diversas cores de miçangas. Os rapazes muitas vezes usam colares mais longos, com desenhos formados em pendentes retangulares. Crianças, jovens e adultos usam largos braceletes de miçangas, com padrões gráficos semelhantes aos das pinturas corporais, mas também com outras imagens, tais palavras e escudos de times de futebol.

Se é dia de festa, as miçangas aparecem em profusão ainda maior: às gargantilhas, moças e mulheres somam várias voltas de fios de miçangas, que podem ser usados tanto cruzados no peito quanto pendurados no pescoço; também os homens fazem uso destes ornamentos, junto aos colares mais longos. Além disso, as mulheres vestem suas saias vermelhas, às vezes com franjas de miçangas, proporcionando um belo efeito nos momentos de dança, e outras vezes sobrepostas por um keweyu, tanga frontal feminina, a mais bela peça de miçanga produzida na região, com imbricados padrões gráficos. Os homens, por sua vez, colocam sobre suas compridas tangas vermelhas, chamadas kamisa, cintos de miçangas, os 
chamados panti. As composições gráficas que aparecem em um panti tem seus motivos oriundos de um repertório diverso daquele do keweyu: motivos estes aprendidos por meio de livros de ponto-cruz pertencentes aos missionários evangélicos que chegaram na região em meados dos anos 1970, trazendo imagens como a ordenha de uma vaca, helicópteros, leões etc. Cotidianamente, as mulheres se empenham na produção desses adornos corporais, também experimentando a criação de outros objetos, como porta-canetas, pequenos animais, bolsas e cestinhos.

Lúcia van Velthem (1998) propõe a descrição e a análise da cestaria wayana, enquanto categoria artesanal, destacando sua confecção ser feita pelos homens Wayana e sua utilização ser, sobretudo, realizada pelas mulheres Wayana. Inspirada no trabalho dessa antropóloga, posso dizer que a presente pesquisa também se interessa em descrever e analisar uma categoria artesanal, mas desta vez produzida pelas mulheres e utilizada por todas as pessoas, independente de gênero ou idade, ainda que de modos diferentes: os adornos de miçangas.

Como já adiantava a autora em seu argumento, não se trata de uma análise meramente descritiva deste aspecto da cultura material, e sim um exercício de relacionar objetos feitos de miçangas, bem como suas técnicas, usos e circulação, a aspectos mais amplos das cosmologias dos povos indígenas karib guianenses ${ }^{2}$, foco de nossa pesquisa, em especial àqueles situados no que se convencionou chamar de sudeste oriental das Guianas. Recorte este puramente analítico, como se pode perceber pelas extensas redes de relações que tanto viajantes de séculos passados descreviam por via das trocas, quanto se pode apreciar pelos grupos de transformações que podemos perceber em seus mitos, ritos e culturas material e imaterial.

\section{Enlaces iniciais: aproximações ao tema da pesquisa}

Desde os trabalhos de Boas ((1927) 2014) até os dias de hoje, passando pelas incontornáveis propostas de Gell $(1992,1998)$, diversos trabalhos antropológicos de fôlego têm evidenciado a relevância dos sistemas artísticos nas mais diversas sociedades, ainda que a ideia de arte seja "muito mais conceito do que fenômeno", como coloca Van Velthem (2010), e concordam tantos outros autores (Dubin, 1987; Vidal, 1992; Lagrou, 2009 são apenas alguns

2 As relações com povos falantes de outras línguas indígenas, em especial os Wajãpi (tronco tupi) não passarão despercebidas ao longo dessa dissertação. O destaque adotado neste trabalho é um recorte devido apenas às questões pragmáticas de execução da pesquisa. 
exemplos). Nas Terras Baixas da América do Sul, dentre as descrições etnográficas que dão conta do assunto, podemos destacar a análise da arte kadiwéu feita por Lévi-Strauss (1996), bem como a compilação de artigos organizada por Lux Vidal (idem) ou a síntese realizada por Lagrou (idem), quando propõem um panorama da arte indígena no Brasil, e muitos são os autores que tratam de elaborações artísticas entre povos ameríndios e suas cosmologias, como Barcelos Neto (2008) e Van Velthem (2003). A importância do uso de miçangas na produção de artefatos e adornos corporais entre os ameríndios é notável em vários aspectos, não apenas porque veio substituir e incrementar elementos decorativos antigos, ressaltando o repertório de padrões gráficos, mas também por permitir a elaboração de novas formas e composições.

Dentre os diversos questionamentos que têm me acompanhado no processo dessa pesquisa de mestrado, posso destacar aquele que tange a "importância" de meu tema de pesquisa, assim como da centralidade dessa importância, e do que, afinal, se entende por um tema ser "importante" ou não. Assumidamente, o engajamento político com o que se convencionou chamar de minorias tem apelo fundamental no caminho antropológico que acredito estar seguindo e construindo. Neste sentido, o que é especialmente interessante na "Antropologia enquanto ciência menor", como coloca Viveiros de Castro (2015) é a capacidade inerente à disciplina de questionar e enfrentar o que se estabelece como modelo. Isso ocorre à medida que as questões antropológicas se deixam contaminar pelos questionamentos daqueles com quem se trabalha em campo.

"Epistemológica, portanto política" - é assim que Viveiros de Castro condensa a questão axial da Antropologia enquanto ciência menor. No caso daqueles que, como eu, encontram-se engajados junto aos povos ameríndios, a "economia da corporalidade" (2015: 40) aparece como central, bem como sua implicação de uma multiplicidade de pontos-de-vista - características que permitiram a proposição do perspectivismo por Eduardo Viveiros de Castro e Tânia Stolze Lima.

A fabricação do corpo como tema inescapável do pensamento ameríndio (Seeger et allii 1979), está demonstrada em inúmeras pesquisas produzidas ao longo dos anos. De modo geral, as etnografias têm constatado que as reflexões e ações ameríndias em torno do corpo humano exigem que se leve em conta que a humanidade é considerada como fundo comum para os diversos seres que existem. Seres estes que diferem em termos de corpos, sendo que o corpo humano precisa ser constantemente produzido para garanti-lo enquanto tal. Essa 
produção implica em processos constantes e rotineiros, tal como a alimentação e a ornamentação, dentre outros.

Quero aqui, finalmente, apresentar o que elegi como meu tema de pesquisa: as miçangas em uso e circulação entre os povos indígenas falantes de línguas karib que habitam a porção oriental da região etnográfica guianense, abrangendo norte do Pará e Amapá, do lado brasileiro, e Suriname e Guiana Francesa, do outro lado da fronteira. Esses povos são conhecidos principalmente pelos seguintes etnônimos: Tiriyó, Katxuyana, Wayana e Aparai, embora sua sociodiversidade seja muito mais complexa do que essas nomenclaturas utilizadas nas relações com o Estado, conforme explicitaremos a seguir, e aprofundaremos ao longo da dissertação.

Não é de hoje que a circulação de braceletes e colares entre povos indígenas interessa à pesquisa antropológica. O que apresentarei nessa dissertação de mestrado são dados e reflexões a respeito do que se faz e do que se fala quando se trata de miçangas, segundo as propostas de uma etnografia atenta também aos objetos (Latour 2002, 2008; Henare et allii, 2007). Assim, pretendo apresentar alguns usos e efeitos das miçangas nas relações estabelecidas entre as diferentes gentes que circulam no contexto da Guiana Indígena. Com isso, espero evidenciar a composição heteróclita de mundos em que a fabricação de corpos e a beleza são fundamentais, ainda que também perigosas e laboriosas.

\section{A região em estudo}

A região do escudo guianense, localizada ao norte da América do Sul, entre os rios Amazonas e Orenoco, é ocupada por diversos povos indígenas, todos eles grandes apreciadores das miçangas. Dentre esses povos, em sua porção sudeste oriental, podemos destacar os Tiriyó, Katxuyana, Wayana e Aparai, denominações genéricas que englobam diversas outras autoidentificações, como veremos a seguir, cujo contato com as miçangas remonta à chegada dos colonizadores, tendo se dado primeiramente pelas relações de troca com os mekõro, categoria generalizada na região para se referir aos diversos povos marrons ou bush-negros, descendentes de negros trazidos da África na condição de escravos, e que fugiram, passando a habitar as florestas do Suriname e da Guiana Francesa, como os Saramaká e os Djuká, dentre outros. O uso cotidiano de pulseiras e colares por homens e mulheres de todas as faixas etárias desses povos é certeiro, mas comedido, contrastando com 
a profusão de contas com que se vestem em dias de festas, quando se agregam ao vestuário diversas voltas de fios de miçangas, além de saias frontais para as mulheres (keweyu, em língua tiriyó) e cintos para os homens (panti, nessa mesma língua).

Os processos de fusão entre a miríade de diferentes gentes dessa região se deu pelo evento histórico da instalação de bases missionárias em pontos específicos de afluentes da margem esquerda do Rio Amazonas, principalmente ao longo da década de 1960 (Grupioni, 2002). No caso das hoje demarcadas Terras Indígenas Parque do Tumucumaque e Rio Paru d'Este, duas missões instalaram-se, uma próxima às cabeceiras do rio Paru de Oeste, e outra no meio curso do rio Paru d'Este. No rio Paru de Oeste, acompanhando a Missão Franciscana de origem alemã, instalou-se uma base da Força Aérea Brasileira; já no rio Paru d'Este, junto à Missão Evangélica Summer Institute of Linguisticas - SIL, norte-americana, houve a instalação de um posto da FUNAI, hoje desativado. O movimento de concentração e dispersão que acontece na região pode ser acompanhado pela sequência de mapas que aparecem na linha do tempo do Plano de Gestão Territorial e Ambiental da região (2018), focado nos Tiriyó, em que mapas produzidos por Frikel $(1971)^{3}$ mostram cerca de 50 aldeias na década de 1950, apenas 2 no final da década de 1960 (Missão Tiriyós no Brasil e Sipaliwini no Suriname), e cerca de 30 aldeias agora nos anos 2010.

Nesse processo, na porção oeste da região oriental das Guianas, as diferentes gentes (yana) que habitam a região, como os Aramayana (gente-abelha), Pianokoto (gente-gaviao), Pïrouyana (gente-flecha), dentre outras, viram-se englobados sob a única denominação Tiriyó, enquanto no lado leste, os Wayana e os Aparai acabam por englobar Upurui, Pixiriyana, Kumarawana, dentre outros grupos. Atualmente, o autorreconhecimento dessa sociodiversidade tem se fortalecido, com especial ênfase na reocupação de territórios de aldeias antigas, devido às dinâmicas de ocupação territorial locais, em que as calhas de rios são ocupadas por determinados yana, e não outros. Isso faz com que reconhecer-se sob o guarda-chuva de determinados yana hegemônicos implique em restrições de ocupação territorial. Notamos aqui que a autodenominação em língua tiriyó que engloba essas diferentes gentes é Tarëno, que, literalmente, pode ser traduzida por “os daqui”. Essa expressão é de cunho eminentemente relacional, isto é, Tarëno pode englobar apenas as pessoas de yana oriundos de determinada região (os Pïrouyana, Aramiso, Aramayana, em relação aos Waiwai,

3 Esses mapas podem ser apreciados na pág. 57 da presente dissertação. 
por exemplo), assim como pode designar "povos indígenas” (os Kayapó, os Guarani, os Tiriyó, em relação aos karaiwa - não-indígena/brasileiro).

O Complexo Tumucumaque é formado por duas terras indígenas (TI) contíguas, TI Parque do Tumucumaque e TI Rio Paru d'Este, localizadas no norte do Pará, na fronteira com o Suriname. Juntas, essas terras indígenas totalizam 4,2 milhões de hectares. Os principais cursos d'água dessas terras são o rio Paru de Oeste e seu afluente rio Marapi, na porção ocidental da TI Parque do Tumucumaque, e o rio Paru de Leste e seu afluente Citaré, na porção oriental. Embora existam fortes relações entre os povos indígenas que habitam ambos os cursos dos rios (conforme poderá ser percebido ao longo da dissertação, bem como em outros trabalhos, tal Gallois 2005), vemos um adensamento de relações entre aldeias que habitam o mesmo rio. Assim, o que chamamos aqui de "lado oeste" faz referência ao local de habitação das populações que vivem nos rios Paru de Oeste e Marapi, onde se fala predominantemente a língua tiriyó, e de "lado leste", o local que habitam as populações ao longo do rio Paru de Leste, onde além da língua tiriyó no seu alto curso, são faladas principalmente as línguas wayana e aparai, nos médio e baixo curso do mesmo. Importante destacar que essa divisão tem sido pensada pelas próprias comunidades, no âmbito de elaboração de seu Plano de Gestão Territorial e Ambiental (2018) e de seu Protocolo de Consulta (em processo de finalização). O que elas destacam é que existem muitas especificidades entre si, mas que também existem muitos problemas em comum, contra os quais estão mais fortalecidos se pensarem e atuarem juntos - nisto se refere principalmente as situações envolvendo o Estado Brasileiro, como Atendimento à Saúde e Educação Escolar (que, na região, estão a cargo do estado do Amapá).

Além das duas terras indígenas acima mencionadas, diversas outras unidades de conservação foram criadas na região, compondo o maior corredor de áreas protegidas do mundo. Há, ainda, as TI Trombetas-Mapuera e TI Nhamundá-Mapuera, já demarcadas e homologadas, e a TI Kaxuyana-Tunayana, ainda em processo de demarcação, além das TI Wajãpi e Zo'é, também demarcadas e homologadas (ver Fig. 1).

A intensa circulação dos povos na região não se limita a esses momentos de concentração e dispersão. Ao longo dos séculos, intensas redes de trocas de bens e matrimoniais fazem com que haja grande compartilhamento de saberes entre esses povos (Gallois, 2005). Um caso exemplar em que se pode apreender esse compartilhamento é no repertório gráfico dos povos da região, como podemos ver ao contrastar o Livro das Artes 
Visuais Tiriyó e Katxuyana (Grupioni, 2009), o Livro das Artes Gráficas Wayana e Aparai (Van Velthem \& Linke, 2010) e Kusiwa: pintura corporal e arte gráfica wajãpi (Gallois, 2002).

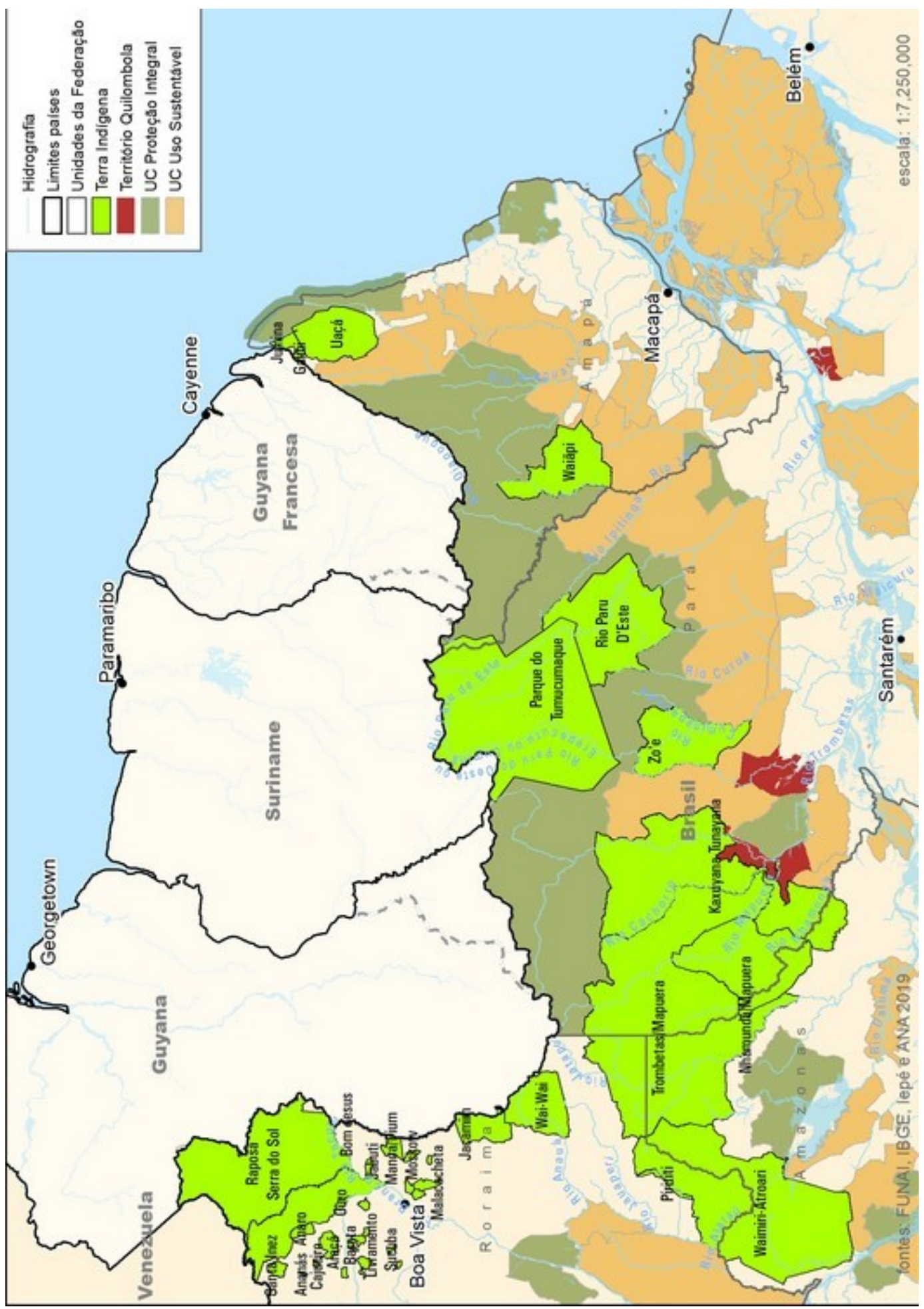

Figura 1: Mapa da região, com destaque para as Terras Indígenas e rios, elaborado por Thomas Gallois. 


\section{Condições de pesquisa e realização de trabalho de campo}

Antes de iniciar esta pesquisa de mestrado, passei a integrar a equipe do Instituto de Pesquisa e Formação Indígena - Iepé, a qual sigo pertencendo até o presente momento. Assim, o trabalho aqui apresentado não pôde contar com o apoio de instituições de fomento à pesquisa, nem de dedicação exclusiva para sua execução. Ainda assim, tive o apoio fundamental da organização não-governamental em que atuo, que possibilitou estar junto aos povos indígenas com quem dialoguei em muitas situações, como explico a seguir.

Minha primeira ida a campo ocorreu ainda durante minha pesquisa de iniciação científica $^{4}$, em 2012, quando pude acompanhar uma das oficinas promovidas pelo Iepé, com apoio do Museu do Índio/Funai, visando a constituição de um acervo de peças tiriyó e katxuyana. Nessa oportunidade, pude acompanhar a entrega das miçangas enviadas pelo Museu do Índio às artesãs Tiriyó e Katxuyana. O próprio Museu do Índio encarregava-se da aquisição dessas peças, muitas das quais podem ser apreciadas na exposição "No Caminho da Miçanga", sob curadoria de Els Lagrou, cujo catálogo (Lagrou, 2016) é uma das referências importantes para esta pesquisa. De 2012 para cá, pude visitar todas as terras indígenas habitadas por povos falantes de línguas karib da região (Rio Paru d'Este, Parque do Tumucumaque, Kaxuyana-Tunayana, Trombetas-Mapuera e Nhamundá-Mapuera), sempre no âmbito de colaborações com o trabalho do Iepé.

1. Agosto/2012. TI Parque do Tumucumaque. Na aldeia Missão Tiriyós, acompanhei a distribuição de miçangas enviadas pelo Museu do Índio, bem como a produção de desenhos no âmbito do ProgDocCult Tiriyó/ Museu do Índio.

2. Março/2014. TIs Rio Paru d'Este e Parque do Tumucumaque. Na aldeia Bona, participei da documentação da primeira oficina de cerâmica realizada com apoio do Prêmio Culturas Indígenas. Nesta mesma estadia, pude fazer parte do acompanhamento dos pesquisadores indígenas que estavam trabalhando num

4 Entre 2011 e 2013, fui bolsista da Sociedade de Amigos do Museu do Índio, realizando pesquisa de iniciação científica no âmbito do ProgDocCult Tiriyó, sob a orientação de Denise Fajardo Grupioni. Essa pesquisa intitulava-se "Grafismos Indígenas nas Guianas", e discutia as redes de relações entre os povos Tiriyó, Katxuyana, Wayana, Apalai e Wajãpi, perceptíveis via os sistemas gráficos desses povos. 
levantamento socioeconômico de suas aldeias (Manau, Matawaré e Parapará, na TI Rio Paru d'Este; Missão Tiriyós, na TI Parque do Tumucumaque).

3. Junho/2014. TIs Trombetas-Mapuera e Nhamundá-Mapuera. Na aldeia Mapuera, participei do acompanhamento dos pesquisadores indígenas ligados à mesma atividade acima mencionada. Já em Kassawá e Santa Maria, integrei a equipe que promovia a elaboração de diagnóstico socioambiental no âmbito de projeto apoiado pelo PDPIMMA.

4. Novembro/2014. TI Parque do Tumucumaque. Participei da II Oficina de Ortografia Katxuyana, na aldeia Santo Antônio, com a presença do linguista Spike Gildea. Fui responsável pelo apoio e pela relatoria da atividade.

5. Fevereiro/2015. TI Trombetas-Mapuera. Juntei-me à equipe que estava trabalhando na aldeia Inajá, também no âmbito do PDPI.

6. Novembro/2015. TI Parque do Tumucumaque. Ocorre a III Oficina de Ortografia Katxuyana, encabeçada pela educadora Maria Cristina Troncarelli, na aldeia Santo Antônio; pude colaborar na relatoria e no suporte à oficina.

7. Maio/2016. TI Katxuyana-Tunaya. A IV Oficina de Ortografia Katxuyana tem lugar na aldeia Santidade, novamente contando com o linguista Spike Gildea, mas também com a presença dos antropólogos Ruben Caixeta e Denise Fajardo. Novamente contribui na relatoria e suporte.

8. Julho/2016. TI Parque do Tumucumaque/Oeste. Assim que passei a integrar oficialmente o quadro do Iepé, me coube conduzir oficinas de diagnóstico com os jovens nas aldeias, sendo a primeira delas na Missão Tiriyó.

9. Agosto/2016. TI Rio Paru d'Este. Segunda oficina de diagnóstico com os jovens, dessa vez na aldeia Bona.

10. Fevereiro e Março/2017. TI Parque do Tumucumaque/Oeste. No âmbito da implementação do PGTA do Complexo Tumucumaque, acompanhei as atividades de campo nas aldeias Santo Antônio, Pedra da Onça, Cuxaré, Aiki e Urunai.

11. Fevereiro/2018. TI Trombetas-Mapuera. Colaborei no trabalho de atualização de diagnóstico socioambiental das TIs do Complexo Trombetas/ União Territorial Wayamu ${ }^{5}$, aldeia Jatapuzinho.

5 Como sido denominado o conjunto das TIs Kaxuyana-Tunayana, Trombetas-Mapuera e NhamundáMapuera. As Terras Indígenas Parque do Tumucumaque e Rio Paru d'Este têm sido designadas como Complexo Tumucumaque. 
12. Maio/2018. TI Kaxuyana-Tunayana. Expedição Diagnóstica para elaboração de Plano de Gestão Territorial e Ambiental nas aldeias do rio Cachorro (Chapéu, Santidade e Maharawani);

13. Junho/2018: TI Rio Paru d'Este. Acompanhamento da IV Etapa de Formação de Jovens e Lideranças/Leste, na aldeia Parapará;

14. Junho/2018. TI Kaxuyana-Tunayana. Acompanhamento e registros audiovisuais da Festa Kahyana (rio Trombetas, aldeias Kaxpakuru, Araçá e Pürho Mïti);

15. Julho/2018. TI Parque do Tumucumaque/Oeste. Acompanhamento da Assembleia da APITIKATXI (Associação dos Povos Indígenas Tiriyó, Katxuyana e Txikiyana) e da apresentação da Articulação das Mulheres Indígenas Tiriyó, Katxuyana e Txikiyana;

16. Agosto/2018. TI Kaxuyana-Tunayana. Expedição Diagnóstica de Plano de Gestão Territorial e Ambiental nas aldeias do Alto Rio Trombetas (Ayaramã e Turuni);

17. Outubro e Novembro/2018. TI Parque do Tumucumaque/Oeste. Assembleia Extraordinária da APITIKATXI, V Etapa da Formação de Jovens e Lideranças/Oeste, Atividades da Articulação de Mulheres Indígenas, I Oficina de Elaboração de Protocolo de Consulta/Oeste;

18. Dezembro/2018. Macapá. Essa ida a campo contou com apoio financeiro (parcial) do PPGAS/USP. Realizei encontros com as mulheres indígenas tiriyó, katxuyana, wayana e aparai na sede da APIWA - Associação Povos Indígenas Wayana e Aparai e na CASAI - Casa de Saúde Indígena;

19. Janeiro e Fevereiro/2019. TI Parque do Tumucumaque/Oeste. Exclusivo trabalho de campo para o mestrado. Visitei as aldeias Missão Tiriyó, Tuhaentu, Orokofa Nova, Ponoto, Oroientu;

20. Fevereiro/2019. TI Parque do Tumucumaque/Leste. Pactuação do Projeto Orixiyana, proposta pelas mulheres wayana e aparai, e aprovado pela Embaixada da Noruega. I Oficina de Elaboração de Protocolo de Consulta/Leste.

21. Março/2019. TI Parque do Tumucumaque/Oeste. Acompanhamento da VI Etapa de Formação de Jovens e Lideranças/Oeste, na aldeia Missão Tiriyó. II Oficina de Elaboração de Protocolo de Consulta/Oeste.

22. Abril/2019: TI Rio Paru d'Este. Acompanhamento da VI Etapa de Formação de Jovens e Lideranças/Leste, na aldeia Xuixuimene. 
23. Junho/2019: TI Parque do Tumucumaque/Leste. II Oficina de Elaboração de Protocolo de Consulta/Leste.

Além dessas atividades em áreas indígenas, participei também do II e do III Encontros de Mulheres Indígenas, em outubro/2016 (Macapá/AP) e agosto/2017 (Rio Branco/AC), bem como do Intercâmbio Regional de Mulheres Indígenas na TI Wajãpi, em novembro de 2018. Também estive presente na V Oficina de Ortografia Katxuyana aconteceu em Oriximiná, em maio de $2017^{6}$, na VII Oficina de Língua Katxuyana/Wërikiyana, em Santarém (maio de 2019), e na Oficina de Revisão dos Livros de Nutrição nas línguas tiriyó, katxuyana (wërikiyana), wayana e aparai, em Macapá (agosto de 2019).

Na ocasião do exame de qualificação desta pesquisa de mestrado, em junho de 2018, foi realizado o convite para a visita ao acervo de peças de miçangas dos povos indígenas Tiriyó, Katxuyana, Wayana e Aparai, depositado na Reserva Técnica do Museu Paraense Emílio Goeldi. O convite foi feito pela antrópologa Lúcia Hussak van Velthem, curadora do respectivo museu, e membro da banca tanto de qualificação quanto de defesa desta dissertação. Após os devidos trâmites burocráticos e o apoio do Instituto de Pesquisa e Formação Indígena Iepé, a visita foi realizada entre os dias 10 e 14 de junho de 2019, contando com o apoio não só de Lúcia van Velthem e Suzana Karipuna (funcionárias da instituição), mas também de Ângela Amanakwa Kaxuyana, com quem pude estabelecer proveitosa interlocução ${ }^{7}$.

O Museu Paraense Emílio Goeldi conta com 23 coleções de objetos dos povos indígenas Tiriyó e Katxuyana (incluídos nessas designações também os Aramagoto, Akuriyó, Txikiyana, Aramayana, Ewarhoyana), totalizando 1.296 peças, coletadas entre os anos de 1958 e 1975, por diferentes pessoas. O maior coletor foi Protásio Frikel, diversas vezes designado como único coletor, mas outras tantas contando com o apoio (ou apoiando) Roberto Cortez, Ruth Cortez e Ruth Wallace. Peças pontuais são designadas como doação de Frei Angelico Miehert e Sargento Afonso Leão do Vale. As duas coleções mais recentes (1975)

6 A partir desta oficina, os falantes da língua decidiram que o mais adequado era nomeá-la língua wërikiyana, posto ser falada também pelos Kahyana, Yaskuriyana e outros.

7 Essa visita irá se desdobrar num outro pedido de acesso ao acervo, desta vez feito pela AIKATUK e pela APITIKATXI (respectivamente, Associação dos Povos Indígenas Katxuyana, Tunayan e Kahyana; e Associação dos Povos Indígenas Tiriyó, Katxuyana e Txikiyana). Tanto a primeira visita que realizei com Ângela Kaxuyana quanto essa segunda visita contam com o apoio fundamental do Programa Tumucumaque/ Iepé, no âmbito de ações de valorização e fortalecimento cultural. 
foram feitas por Roberto e Ruth Cortez. Uma única coleção de peças katxuyana foi realizada exclusivamente por Ruth Wallace (1972), no rio Paru de Oeste.

Dessas 1.296 peças catalogadas como procedentes dos povos Tiriyó e Katxuyana no acervo do Museu Paraense Emílio Goeldi, 115 são descritas nos livros de tombo como sendo feitas de miçangas. Nos momentos finais de minha visita, encontramos algumas peças que possuíam miçangas, apesar de não estarem assim descritas nos livros de tombo. Trata-se de pequenas estatuetas de madeira zoomorfas, descritas como sendo amuletos para atração de caça, cujos olhos são pequenas miçangas ou brancas ou vermelhas. Infelizmente, não foi possível realizar um exame minucioso de toda a coleção, o que certamente seria de grande interesse - o que por si só já aponta possíveis desdobramentos para essa pesquisa.

Dado o curto prazo disponível para a consulta do acervo, só pude analisar 37 dessas 115 peças. Além disso, por conta de situações burocráticas, a visita só pôde ser realizada já próxima à data de depósito da dissertação. Sendo assim, apesar de não apresentar aqui uma análise exaustiva das coleções Tiriyó e Katxuyana do Museu Paraense Emílio Goeldi, é possível indicar recorrências e variações entre essas peças encontradas no acervo do MPEG e aquelas produzidas atualmente. Além disso, diálogos que pude estabelecer a respeito dessa visita com diferentes interlocutores e interlocutoras demonstram grande interesse da parte desses povos indígenas em conhecer as coleções a eles pertencentes.

Das 37 peças analisadas, 24 estão designadas como sendo de origem Tiriyó e 13 de origem Katxuyana. Todas as peças tiriyó indicam como sua procedência o rio Paru de Oeste, sendo que 2 trazem a especificação do grupo Aramagoto (Aramayana) e 1 do grupo Charuma. As peças katxuyana indicam duas procedências geográficas: 5 delas foram coletadas no rio Cachorro, afluente do rio Trombetas, e 8 delas no rio Paru de Oeste, sendo uma delas (9355) particularmente interessante por ter sido coletada em 1961, ou seja, antes da remoção dos Katxuyana para a Missão Tiriyó (em 1968).

Essas atividades me possibilitaram tanto estabelecer relações com essas pessoas, como também vislumbrar semelhanças e diferenças que perpassam toda a região, e que podem ser especialmente percebidas através do estudo das artes visuais destes povos indígenas. Ainda que eu não tenha podido passar uma longa temporada dedicada exclusivamente ao foco priorizado na pesquisa de mestrado, entendo como ricas as experiências vividas neste âmbito indigenista. Mesmo que essas incursões a campo tenham motivações claras e objetivos 
definidos, pude aproveitar desses momentos para eu mesma começar a aprender a tecer tantos pulseiras e colares quanto tecer minhas relações com essas pessoas.

Questões relacionadas à circulação e ao uso das miçangas emergem com muita facilidade nas interações, seja nas aldeias, seja nas cidades, e não posso deixar de notar que parte do meu campo tem acontecido aqui mesmo em São Paulo. Isto porque tenho colaborado com algumas mulheres tiriyó, katxuyana, wayana e apalai na venda de suas peças de miçangas, já tendo recebido desde agosto do ano passado por volta de 400 peças para comercializar. Muitas das vezes, elas pedem para que ao invés do dinheiro das vendas, sejam enviadas mais miçangas, o que me exige idas frequentes ao centro da cidade para a compra das miçangas diretamente em sua importadora. O trânsito frequente de miçangas e peças de miçangas tem sido possível graças às constantes viagens de colegas de equipe no Iepé.

Uma surpresa interessante, nessas idas ao centro de São Paulo foi conhecer Moisés Henrique Lameira Filho, um dos mais antigos funcionários da atualmente denominada LDI Cristais e Pedrarias, a importadora das miçangas mais apreciadas pelos povos indígenas na América Latina, oriundas da República Tcheca. Moisés é responsável apenas por dois tipos de clientes: estabelecimento de alto nível localizados em bairros nobres de São Paulo e povos indígenas. Segundo o vendedor, todos os dias aparecem clientes indígenas para fazer compras na loja, no mais das vezes pagando à vista e comprando quantidades significativas de miçangas. Moisés aprecia o trabalho com os índios, conhecendo as variações dos gostos conforme a origem dos povos e mantendo uma pequena galeria de peças produzidas por seus clientes preferidos.

\section{Plano da dissertação}

Essa dissertação compõe-se da presente Introdução, seguida de três capítulos, e arrematada por breves "Considerações Finais". Os dados aqui mobilizados pretendem dar conta de evidenciar como as miçangas - ou, antes, as relações que as envolvem e mobilizam podem ser boas para pensar os modos como os povos indígenas do sudeste guianense compõem seus sistemas de vida e mundos.

O primeiro capítulo traz um panorama amplo das apropriações e circulação das contas na América Indígena, mostrando como o apreço por esses objetos é generalizado tanto no tempo quanto no espaço, com suas especificidades. Ainda nesse capítulo, mergulha-se mais 
intensivamente nas apropriações e circulação das miçangas de vidro entre povos indígenas das Guianas, a partir de relatos de viajantes de séculos passados, como o padre Jean de la Mousse (século XVII) e o explorador Jules Crevaux (século XIX), até a atualidade, com o uso de smartphones, passando por fontes etnográficas a partir da metade do século XX.

O segundo capítulo descreve técnicas, materiais, repertórios gráficos e composições de adornos entre os povos do sudeste guianense, evidenciando similaridades e variações em seus padrões estéticos, bem como controvérsias que surgem na relação entre esses povos indígenas e o Estado Brasileiro, com modos distintos de se conceber a autoria e a origem dos padrões gráficos. Neste capítulo, nos interessa destacar a importância da fabricação das peças de miçangas, inspirando-nos nas propostas de Latour (2008) e Gell (2001).

As miçangas compondo corpos entre festas e guerras é o mote do terceiro capítulo, que pretende apresentar certa fractalidade que pode ser percebida ao se analisar estética e ética (dimensões não-apartadas) da vida desses povos indígenas. Para tanto, mobiliza-se elementos da organização social e da cosmologia desses povos - em especial dos Tiriyó, mas sempre evidenciando a centralidade da alteridade e da corporalidade, isto é, da relação com (outros) humanos e não-humanos, e do cuidado essencial na fabricação e manutenção de corpos belos e adequados.

As "Considerações Finais", mais do que encerrar discussões, apresentam pontos de estabilidade a partir dos quais a pesquisa antropológica pode continuar, mostrando como temas clássicos seguem rendendo reflexões interessantes e necessárias a serem feitas na atualidade.

Assim, prepare fios e agulhas para adentrar em tramas de miçangas, tecidas por tantas diferentes gentes. 


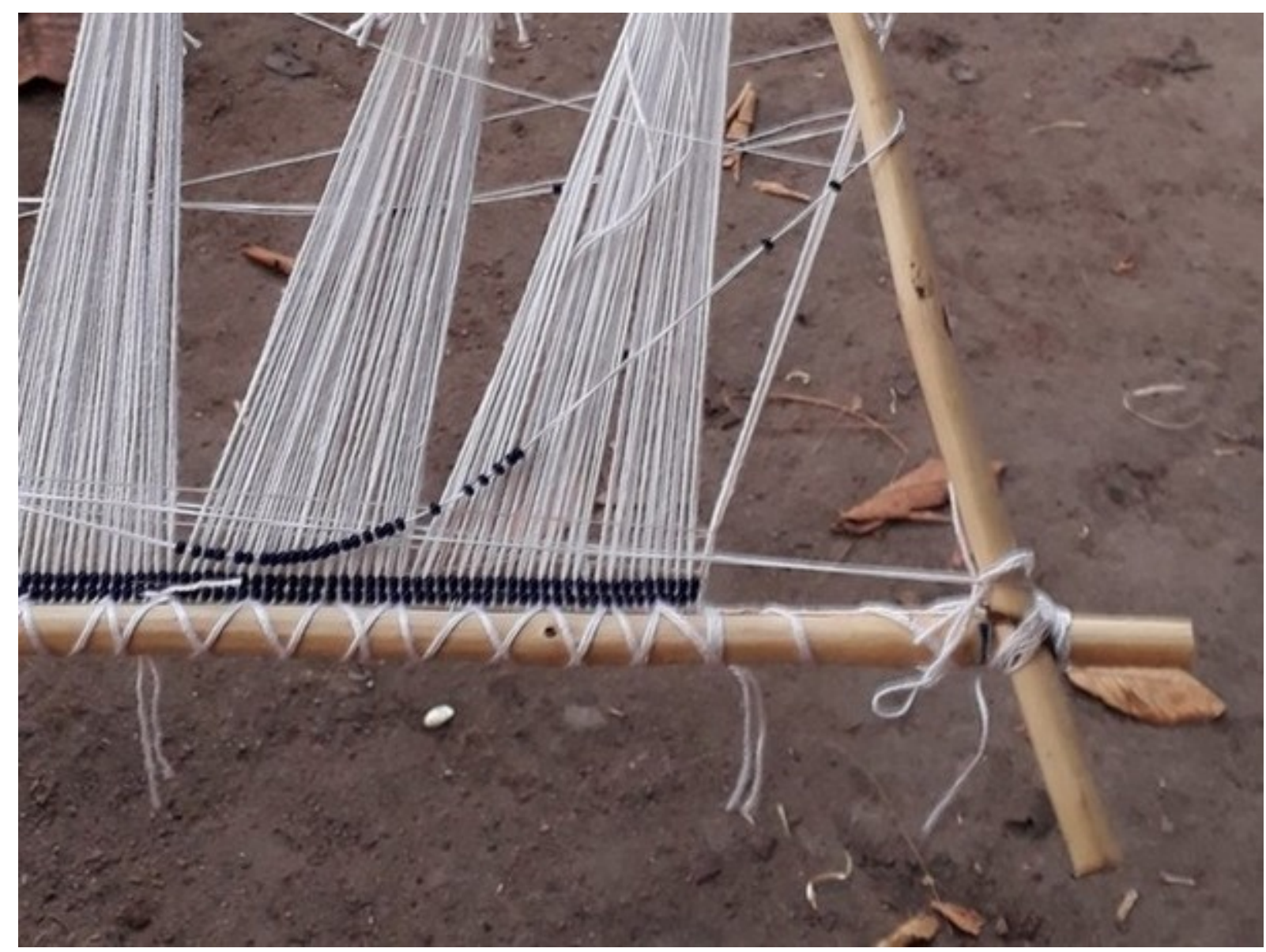

Figura 2: Início do keweyu que Lurdes Kaxuyana estava me ensinando a tecer. Fevereiro de 2019. 
Capítulo 1: De onde vem as miçangas? Apropriações ameríndias 
De acordo com narrativas dos Wayana e Aparai - como a que foi transcrita e traduzida por Schoepf (1976) - as miçangas foram obtidas pela primeira vez quando um rapaz escutou de noite o choro de uma árvore samaúma, pedindo para que ele cuidasse de seus "bichinhos". Os bichinhos eram um japu, um gavião e um pássaro can-can, que o rapaz deveria alimentar com tubérculos cozidos, mantendo-os distantes dos olhos das demais pessoas, dentro de um pakara $^{8}$. Assim fez o rapaz, surpreendendo-se com o aspecto das fezes dos animais: os diferentes alimentos que ele dava aos bichos faziam com que estes defecassem variadas cores de miçangas. Com essas miçangas, o jovem se adornava, usando-as como belas bandoleiras, que causavam inveja nos demais habitantes da aldeia. Um dia, quando o rapaz foi caçar, seu cunhado resolveu abrir o cesto onde ele sabia estarem guardadas as miçangas. Ofendidos, os pássaros foram embora. Ao retornar para a aldeia, o rapaz soube que seus pássaros haviam fugido e se pôs a buscá-los, seguindo as indicações que o próprio Japu lhe dava.

Numa versão que me foi contada por Arawaje Waiana Apalai, quando estávamos a caminho de um encontro de mulheres na Terra Indígena Wajãpi, a narrativa termina quando o rapaz se transforma em karaiwa e segue para o outro lado de uma "grande água", tendo o Japu como seu GPS. Em outras versões, o rapaz também vai para algum local distante, além do grande rio - denominado Parana - e por lá fica. Na versão mais longa que me foi contada por Cecília Awaeko Apalai, muito parecida com a versão traduzida por Schoepf (1976), muitos anos depois o sobrinho desse rapaz resolve ir atrás dele, encontrando-o neste local distante, mas onde todos os tipos de objetos são feitos. Lá, o sobrinho pede ao tio todas as coisas, e ele lhe oferece uma caixa com tampa, que não deve ser aberta até que o sobrinho chegue em sua aldeia - com o que ele consente. Ao longo do caminho, porém, ele passa a duvidar que "todas as coisas" caibam naquela única caixa nem tão grande assim, e a abre. Neste momento, uma profusão de coisas sai de dentro da caixa, aparecendo então a cidade de São Paulo. Espantado, o sobrinho retorna ao encontro de seu tio, e lhe conta o que houve. O tio lhe dá outra caixa de presente, dessa vez menor, refazendo a recomendação de não a abrir até a chegada na aldeia. Ainda que mais empenhado nesta segunda viagem, o sobrinho novamente sucumbe à dúvida de que tudo caberia naquela caixinha, desta vez quando já não estava mais tão distante de sua aldeia. Ao fazer isso, novamente todas as coisas escapam da caixa, desta vez formando a cidade de Belém. Não obtendo mais nada com seu tio, o sobrinho

8 Trançado formando uma caixa, com tampa, também descrita como cofo ou mala, confeccionada por todos os povos da região, podendo tanto trazer grafismos em seu corpo, quanto diferentes padrões de tecelagem (Van Velthem 1998). 
retorna à aldeia, e é por isso que até hoje os Wayana e os Aparai não possuem todos os objetos industrializados, que estavam na primeira caixa.

Entre os Tiriyó, a origem das miçangas é sobretudo atribuída aos mekoro, denominação dada pelos povos indígenas da região aos povos descendentes dos africanos trazidos como escravos para Guiana, Suriname e Guiana Francesa. Contam que, um dia, um tiriyó resolveu seguir escondido os mekoro para descobrir de onde vinham as miçangas; foi assim que ele viu que eram colhidas de diversas árvores que ficavam todas numa mesma região, e eram reunidas em sacos das miçangas separadas por cores, espalhadas aos pés das árvores (Grupioni, 2016: 193).

Essas narrativas conectam muitos dos elementos importantes para abordar os modos de circulação e os usos de adornos e especialmente das miçangas entre os povos indígenas karib guianenses. Na versão contado pelos Wayana e Aparai, destacam-se cores, usos, inveja, longas viagens e mesmo a relação das miçangas com outros materiais de difícil obtenção, via de regra industrializados. Destaca-se o detalhe do mito que indica uma origem não-karaiwa para as miçangas, que teriam vindo por meio do cocô dos pássaros de uma antiga samaúma, conforme sua alimentação, duplamente submetida a processos culturais: cultivos advindos das roças, e depois cozidos.

Neste capítulo, procuro evidenciar alguns aspectos deste apreço indígena por contas e miçangas, iniciando por uma diferenciação entre contas e miçangas, que será aprofundada no segundo capítulo. Mencionarei de modo sucinto alguns importantes achados arqueológicos que evidenciam a antiguidade do uso das contas Américas, bem como trataremos também de alguns pontos cruciais acerca da apropriação e da circulação das miçangas entre os povos indígenas norte-americanos. Por fim, procuro introduzir, de modo mais específico, a apropriação e circulação das miçangas entre os povos indígenas karib-guianenses, preparando o leitor para o capítulo seguinte, que descreverá técnicas, tipos e repertórios, principalmente tiriyó, das artes tecelãs das mulheres da região.

\section{Contas e Miçangas}

Para falar de miçangas, é fundamental que primeiro esteja bem definido do que se trata. Atualmente, em língua portuguesa e aqui no Brasil, "miçanga” é um tipo específico de 
contas: são pequenas, comumente feitas de vidro, esféricas, com um furo no meio, de diversas cores e de uma certa gama de tamanhos. Conforme definição do Dicionário Priberam da Língua Portuguesa, as definições para essa palavra são?

1. Conta miudinha e redonda, de louça ou massa de vidro.

2. Ornato feito dessas contas.

3. Variedade de caracteres tipográficos muito miúdos, correspondente ao tipo 5.

4. Miudezas, bagatelas, bugigangas.

É verdade que existem miçangas feitas de outros materiais, como o plástico, por exemplo, mas aí necessitam do qualificativo para serem descritas. A miçangas tout court são pequenas e de vidro. Aquelas que encontramos no Brasil são fabricadas sobretudo na China e na República Tcheca, com visíveis diferenças tanto no preço quanto na qualidade.

As contas, por sua vez, constituem uma categoria mais ampla, sem restrição de material nem determinação de tamanho; o que importa é que seja um objeto que tenha um furo pelo qual seja possível passar um fio. Trata-se de um dos mais antigos artefatos fabricados por seres humanos, podendo mesmo serem consideradas como um dos principais objetos (se não o principal) que permitem verificar as extensões das redes de trocas desde o primeiro boom da Revolução Neolítica (Dubin, 1987). Assim, as contas podem ser feitas dos mais diversos materiais, como cerâmica, madeira, ossos, sementes, dentes, cascos, metais, ligas, pedras, dentre outros imagináveis, permitindo observar tanto a extensão das redes de trocas quanto as diversas tecnologias que diferentes povos dominavam, de acordo com seus distintos valores estéticos.

Conforme acima apresentado, em língua portuguesa, a palavra miçanga, de origem bantu (África Central), além de designar as pequenas contas de vidro, designa quinquilharias, objetos sem importância. Em outras línguas, essa acepção não encontra eco, como é o caso das diversas línguas karib faladas na região sudeste do escudo das Guianas. Samura, em tiriyó, por exemplo, faz referência à areia; orokowëti, em katxuyana, literalmente significa "cocô de lagarta"; kahulu em aparai, ou kasuru, em wayana, aludem ao formato das primeiras miçangas que chegaram na região, como casulos, elipses, fazendo uso de uma corruptela da língua portuguesa (Van Velthem, 2003).

A importância das miçangas já foi sugerida por autores de áreas como a psiquiatria como ligada tanto à visão quanto ao tato: Erikson (apud Dubin 1987: 19) destaca que as miçangas redondas, que já denotariam complexificações em sua fabricação quando

9 Verbete "miçanga", in Dicionário Priberam da Língua Portuguesa [em linha], 2008-2013, https://dicionario.priberam.org/mi\%C3\%A7anga [Acesso em $1^{\circ}$ de outubro de 2019]. 
comparadas às miçangas não-esféricas, estariam ligadas aos olhos, mas também à maternidade e mesmo às emoções. Já Bross, também psiquiatra, destacaria outro elemento das miçangas: o tato, relacionando-o à amamentação e aos mamilos. Alguns povos indígenas também fazem explicitamente essa associação entre miçangas e olhos, como os Kaxinawa e os Krahô (Lagrou, 2016).

Não discutiremos aqui a validade dessas ponderações. O que queremos destacar é que a importância de contas e miçangas não é recente, nem sua relação com a produção criativa das mulheres. É interessante a ideia de Dubin: "Contas são ferramentas por meio das quais as pessoas transmitem informações para outras pessoas" (idem:19, tradução nossa) ${ }^{10}$. Mais do que ferramentas para passar informações para outras pessoas, a presente pesquisa pretende indicar como o apreço pelas miçangas nos informa acerca de concepções estéticas e políticas dos modos como os povos indígenas guianenses relacionam-se entre si e com outros, humanos, não-humanos, indígenas, não-indígenas, de diferentes idades e gêneros.

Aliás, nota-se a existência de um campo de estudo multidisciplinar chamado "bead research", onde envolvem-se arqueólogos, designers, antropólogos, psicólogos, pesquisadores autodidatas, dentre outros, compondo a Society of Bead Researchers e o Center for The Bead Research, reunindo especialistas de diversos países e publicando materiais como The World of Beads Monograph Series, Occasional Papers of the Center of Bead Research, Contribuitons of Center for Bead Research e Beads and Peoples Series, além do periódico The Margaretologist ${ }^{11}$. Dubin expressa bem o sentido dessas pesquisas: para além da ideia convencional de que miçangas são apenas ornamentos, Como coloca Dubin (1987:17), embora os ocidentais tendem a considerar contas e miçangas apenas como ornamentos, bastando-se à ideia de que não passam de voltas ao redor do pescoço. Contudo, como mostra a autora:

\footnotetext{
"Contas (incluindo miçangas) freqüentemente se alistaram como repositório simbólico de conhecimento sagrado, consideradas como dotadas de poderes curativos, utlizadas como taxa de passagem para a vida após a morte, e utilizadas como promotoras da garantia de uma conduta adequada do ritual e da oração. Contas têm sido meio de troca em permutas e unidades padrão de valor em sistemas de mercado. (...) Frequentemente, contas espelham a cultura da qual fazem parte. (idem, ibidem. Tradução nossa) ${ }^{12}$
}

10 No original: Beads are tools by which people convey information to other people.

11 Estes materiais podem ser encontrados no seguinte link: https://beadresearch.org/cbr-publications/ [Acessado em 01 de outubro de 2019, às 00h39]

12 No original: Beads have frequently enlisted as symbolic repository of sacred knowledge, been deemed to have curative powers, served as fee for passage to the afterlife, and used as promppters to ensure the proper conduct of ritual and prayer. Beads have been the medium of exchange in barter and the standart units of value in market systems. (...) Beads so often mirror the cultura of which the are a part. 
Dubin (1987) sugere como roteiro de análise para pesquisas em miçangas tratar de seus fabricantes, bem como das tecnologias empregadas. Para tratar das miçangas que circulam entre os povos indígenas falantes de línguas karib na região sudeste guianense, primeiro precisaríamos levar em conta os fabricantes dessas miçangas. No caso, o mais fundamental é notar que as miçangas mais apreciadas são aquelas oriundas da República Tcheca. Inclusive, a produção dessas miçangas, na cidade tcheca de Jablonec, encerra grandes segredos. A impossibilidade de produzir a miçanga cor-de-rosa que não desbota é um exemplo disso, pois o único senhor que detinha os conhecimentos acerca de sua produção já é falecido, o que faz de toda miçanga rosa, uma miçanga tingida, conforme me esclareceu o funcionário Moisés, apresentado na Introdução desta dissertação. Também recentemente começaram a ser produzidas miçangas no que na loja é conhecido como "azul-arara", após pedido dos Yekuana.

Como mencionado, Moisés é um dos mais antigos funcionários da LDI Cristais e Pedrarias, única importadora das miçangas Preciosa Ornela (antiga Jablonex), marca preferida pelos povos indígenas, no Brasil. É especializado no atendimento aos povos indígenas que diariamente entram em contato, seja pessoalmente, na loja física, seja por outros canais de atendimento, como site, WhatsApp e telefone. Moisés reconhece diferentes preferências de cores e tamanhos conforme as regiões de onde vêm os povos indígenas, e aprecia grandemente as peças produzidas por esses povos. Aliás, essa intimidade com as preferências dos diferentes povos não se restringe a esse funcionário, pois a empresa como um todo destaca as qualidades estéticas das artes indígenas em miçangas, tanto expondo diversas peças (muitas delas presenteadas pelos próprios índios) quanto pelo texto que aparece no verso do mostruário (Fig. 3).

A produção das miçangas tchecas, na região da cidade de Jablonec, é mantida sob grande segredo. Elizabeth Ewart (2007) conta que tentou visitar a fábrica, sem sucesso, quando esteve na região. Els Lagrou tampouco obteve autorização para conhecer a fábrica, e ainda menos para realizar imagens da mesma - que integrariam a exposição "No Caminho da Miçanga" - apesar do intermédio de embaixadores (2016:30). Na importadora de miçangas que se localiza no centro de São Paulo, há um vídeo que pude assistir em segredo uma vez, mostrando algumas imagens da fabricação das miçangas. Mesmo nesse vídeo, que não é de fácil acesso, as máquinas aparecem completamente cobertas por panos. Conforme me relatou 
Moisés, a preocupação dos tchecos com roubo da tecnologia de fabricar miçangas pelos chineses é muito grande, ainda mais com o crescente aprimoramento das técnicas chinesas.

Entre os povos ameríndios guianenses, falar das miçangas “em si”, sem relacioná-las a outras gentes ou situações, torna-se assunto muito restrito. É claro que é possível descrever aspectos que chamaríamos mais técnicos, como cores e tamanhos preferidos, mas isso de muito pouco serviria, sem levarmos em conta aspectos mais sociológicos e antropológicos da questão - que necessariamente deixam de dizer a respeito das "miçangas elas mesmas". Como disse Peti Tiriyó, "samura não grita": ou seja, se o que se almeja é escutar o que as miçangas têm a dizer, é necessário ouvi-las em meio a situações mais ricas do que aquelas que as isolam.

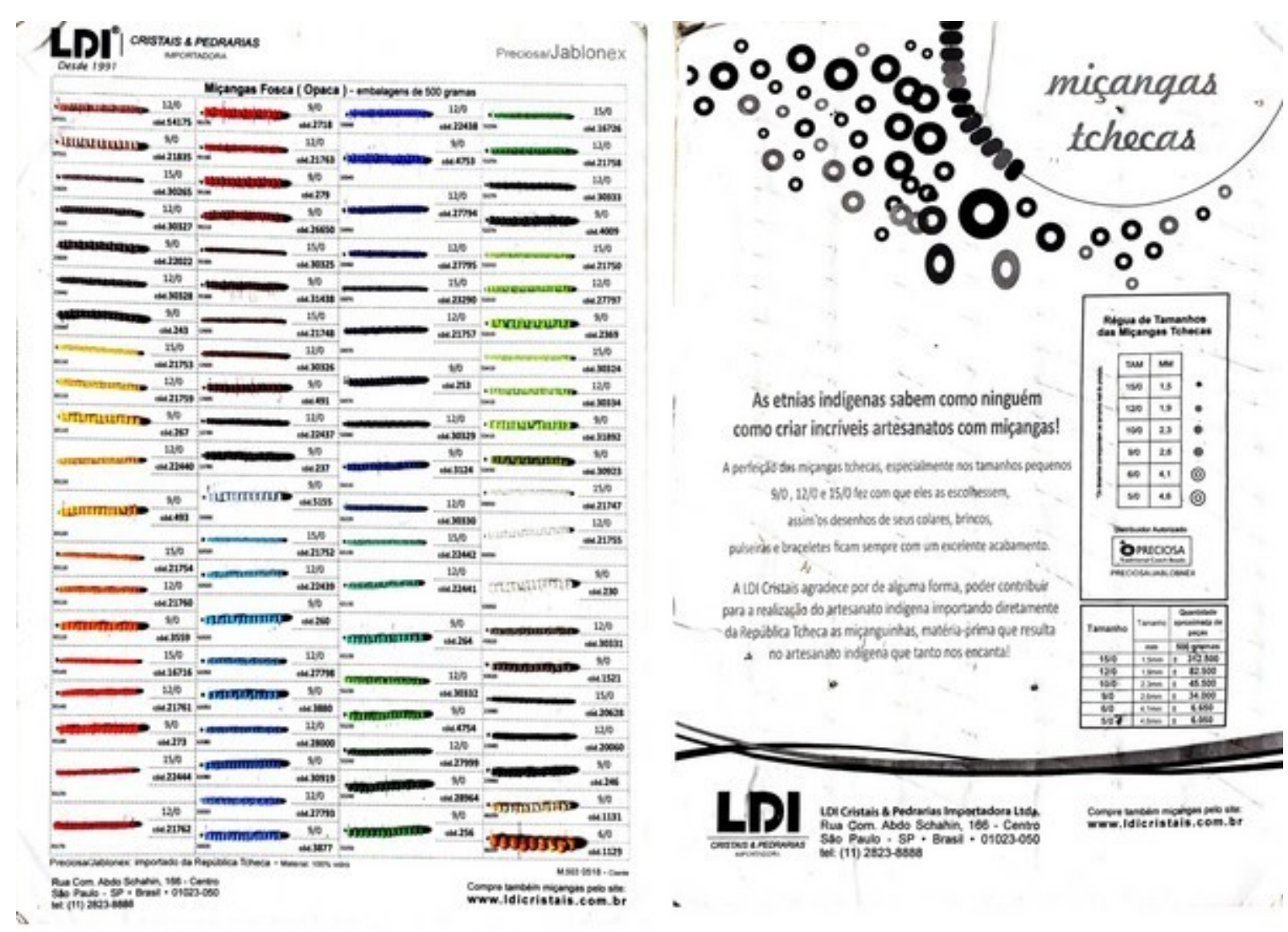

Figura 3: Frente e verso do mostruário de miçangas provenientes da República Tcheca, ou "samura ikuhtu", como chamado em língua tiriyó.

Ainda acompanhando as propostas de Dubin (1987:18), acompanhar as miçangas ao longo do tempo e do espaço permite compreender a história da tecnologia de determinada sociedade. No caso específico que interessa a essa pesquisa, acompanhar as miçangas implica em perceber as diferentes alianças ao longo do tempo, e o modo como elas vão passando (ou 
não) por diferentes linhas de transmissão. Já que a produção tecnológica das miçangas não é feita nas terras indígenas, podemos colocar o foco no entendimento do que seria a tecnologia das miçangas. E também para responder à pergunta: para que servem, afinal, as miçangas?

Nas aldeias, as pessoas dizem que gostam das cores das miçangas, e por isso apreciam tecê-las. O que se vê é a constante reiteração do gosto pela beleza. Além disso, afirmam que é preciso trabalhar com as miçangas para que as moças jovens não esqueçam o que as velhas sabem. Também tem se tornado muito comum justificar-se o gosto pelas miçangas pela possibilidade da venda de pulseiras e colares - aqui, é importante destacar que o ganho monetário possível com essa comercialização aparece como irrisório perto do que mais concretamente motiva de fato essas mulheres quando falam da "venda" de seus colares e pulseiras: a aquisição de mais miçangas para poderem tecer ainda mais peças ${ }^{13}$. Assim, o que é destacado nas aldeias, quando se fala da tecnologia das miçangas, se relaciona com a potência da troca, da diferença e da continuação.

\section{Miçangas e outras contas na América Indígena}

Via de regra, objetos e histórias sobre os europeus circulam entre os povos ameríndios bem antes do contato direto entre essas populações. Karklins \& Sprague (1972) trazem uma pesquisa que aponta essa situação em todas as regiões da América do Norte. As redes de trocas ameríndias, descritas por meio de um grande sistema de transformação de mitos por Claude Lévi-Strauss, talvez também pudesse ser descrita por meio de diferentes usos de miçangas entre os povos do continente americano.

Como mencionado acima, a chegada de Cristóvão Colombo em 1492 é um dos momentos mais citados para se falar das grandes quantidades de miçangas desembarcadas no continente, onde já encontraram grande apreço pelos povos indígenas. As miçangas trazidas por Colombo vinham em fieiras que eram prontamente colocadas em volta do pescoço. Achados arqueológicos também permitem perceber que as contas trazidas pelos europeus vinham de diferentes localidades, fazendo com que a circulação das contas seja ainda mais ampla do que apenas dentro do continente americano.

13 As mulheres indígenas que moram ou vão para a cidade com mais frequência podem ser vistas como mais dependentes do ganho monetário dessa venda. Ainda assim, boa parte das vendas realizadas por elas procuram se reverter na aquisição de mais material miçangas. 
No caso mesoamericano, eram dois tipos de contas trazidos pelos espanhóis: aquelas de materiais considerados preciosos como turquesa, âmbar e pérola, destinadas aos súditos da coroa espanhola, principalmente para a confecção de rosários; as miçangas de vidro, por sua vez, vinham para trocas e outras relações comerciais com os povos nativos, oriundas de vários locais, como Veneza, Flandres, Andaluzia e Boêmia.

Blair (2009) conta que a circulação de contas pelo mundo direcionava os materiais mais depreciados na Europa para os continentes americano e africano, enquanto as pedras preciosas e as outras matérias-primas e trabalhos considerados mais sofisticados circulavam entre Europa e Ásia, em especial Índia. Interessante notar que essa avaliação é recorrente em trabalhos que analisam os valores das contas, depreciando o valor das miçangas de vidro. Esses desacordos entre as concepções indígenas e europeias (ou euro-americanas) em torno das miçangas e das contas é comum, tendo sua expressão mais conhecida na suposta troca da Ilha de Manhattan por um punhado de miçangas. Ainda que alguns considerem essa história como fantasiosa (tal Dubin 1987), há quem prefira argumentar que o conflito central seja a disparidade do valor das miçangas para as diferentes partes, como argumenta Malinda Gray (2017), acadêmica Anishnabee (Ojibwa).

Em seu trabalho, Gray traz um questionamento que também me foi feito várias vezes ao longo de minha própria pesquisa: "Poder-se-ia indagar como trabalho com miçangas poderia ser político. Como contas e miçangas enfiladas em conjunto podem ter tamanho impacto em povos indígenas? ${ }^{14 »}$ (2017:27, tradução nossa). E a resposta dada pela autora materializa-se no wampum, cinto tradicional que circulava entre diversos povos, conforme será apresentado a seguir.

As próximas seções destacarão circulações e apropriações do uso de contas entre povos ameríndios tanto na América do Norte quanto na América do Sul (Terras Baixas), enfatizando esses movimentos na porção sudeste das Guianas, foco desta dissertação. Apesar de não nos determos nos usos e apropriações vigentes na América Central, destacamos dois pontos comuns com povos indígenas das outras duas porções do continente.

14 No original: One might wonder how beadwork could be political? How can beads strung together have an impact on Indigenous people on such a large scale? 


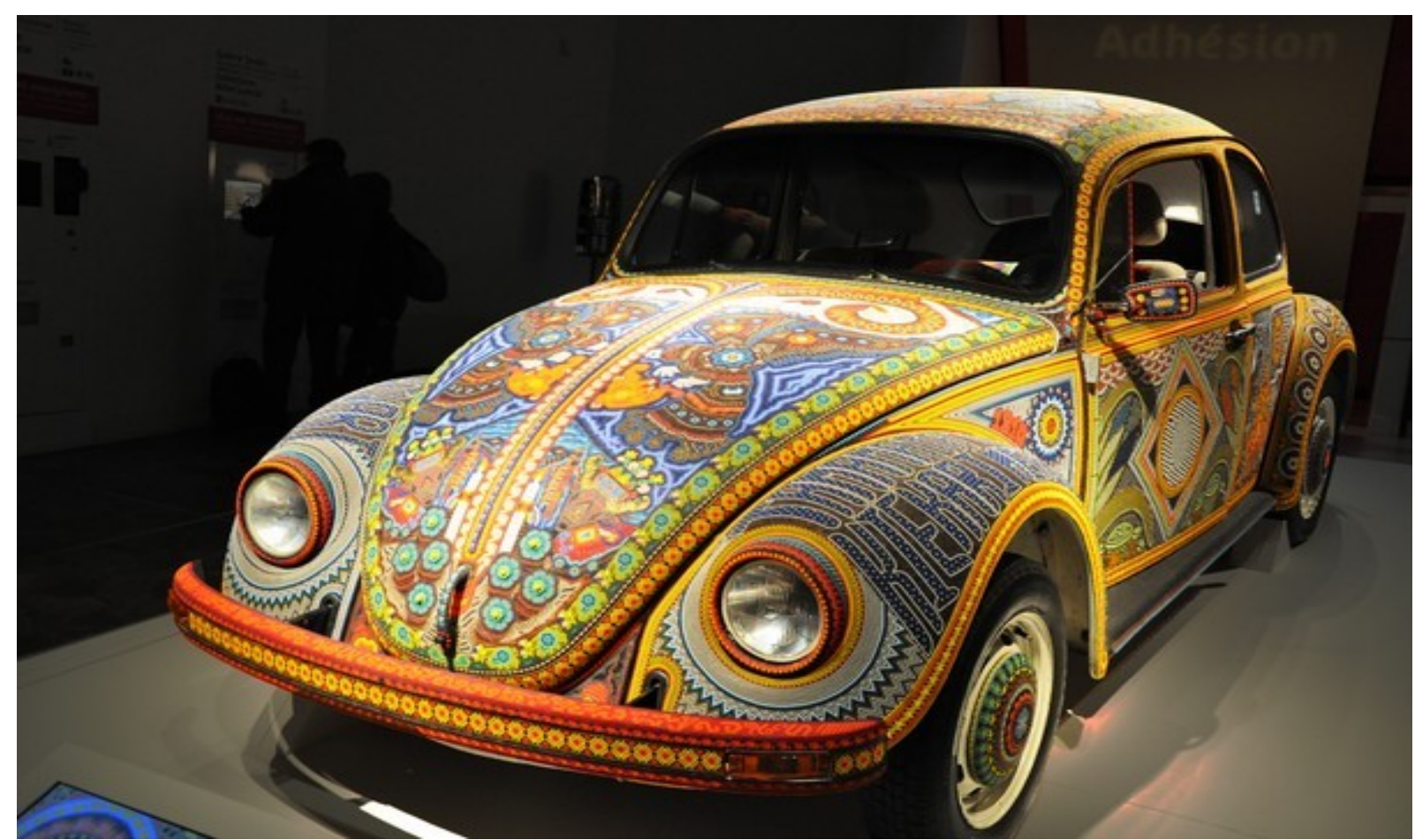

Figura 4: Vochol, o fusca recoberto de miçangas por oito artistas huitchol, quando exibido em Paris, 2012. Imagem acessada em: By Palamède - Own work, CC BY-SA 4.0, https://commons.wikimedia.org/w/index.php? curid $=41639089$. [Acesso em 30 de setembro de 2019]

Um destes pontos é a importância incontestável dos adornos para essas sociedades. Blair (2009) destaca que as rotas de circulação de adornos iam desde as fontes de matériasprimas até o que seriam as capitais das grandes civilizações mesoamericanas. Os espanhóis teriam quebrado essas rotas ao se estabelecerem nesses principais centros, tornando-se também os fornecedores desse novo material, as miçangas de vidro. Segundo a descrição de Blair, as miçangas desses primeiros séculos de colonização seriam, principalmente, translúcidas.

Outra menção interessante a ser feita diz respeito à apropriação criativa das miçangas, com destaque para os reconhecidos trabalhos executados pelos Huitchol. Eles fabricam não só pulseiras com motivos tradicionais relacionados às visões provocadas pelo peyote, como também e sobretudo, recobrem diversos objetos com miçangas, tais como cabeças de onças e outros animais e, no caso de objetos contemporâneos, cobrem com miçangas capacetes de Darth Vader e mesmo um veículo Fusca. Essa cobertura de miçangas apresenta padrões 
estéticos singulares, com composições geométricas e escolhas de cores bem marcantes (Fig. 4).

\section{América do Norte: wampum e quillwork}

Os povos indígenas da América do Norte apreciam largamente diferentes tipos de contas, desde tempos imemoriais. Os achados mais antigos foram registrados em White Caliche, Nevada, remontando ao ano de 11.000 a.C. (Dubin 1987:328). O apreço por diferentes materiais marca o uso feito de contas feito por esses povos, mobilizando extensas redes de trocas estabelecidas para a obtenção de materiais considerados mais raros e/ou duráveis. Um exemplo mencionado por Dubin (idem: 263) são as contas tubulares de cobre, circulando centenas de quilômetros entre Midwest e Woodlands, em tempos anteriores a 3.000 a.C.

Conchas de vários tipos também figuravam entre as contas mais bem quistas para esses povos, com destaque para aquelas do gênero Dentalia, bem como Olivella, além daquelas conhecidas como Mercenaria mercenaria, a partir das quais se produziam as contas dos cintos wampum, objeto ao qual retornaremos adiante. Outros materiais oriundos da própria América do Norte e apreciados para a fabricação de contas eram pérolas de águas doces, garras de animais e pedras de turquesa (provenientes sobretudo da região intermediária com a América Central). Entre os materiais perecíveis, menciona-se sementes de rose hip e de chinquapin.

A mais antiga miçanga de vidro encontrada na América do Norte antecede a chegada de Cristóvão Colombo. Trata-se de um objeto encontrado na província canadense de Terra Nova, num sítio arqueológico de ocupação viking, que teria sido abandonado por sua população por volta de 1347 (Dubin 1987: 271). Contudo, não se pode negar que o impacto das trocas envolvendo miçangas de vidro é marcado de modo veemente pela chegada dos europeus nos séculos seguintes, sendo as miçangas entre os principais itens trazidos por ingleses, franceses, suecos, holandeses e espanhóis, como menciona Dubin (idem).

No Ártico, as miçangas conhecidas em língua inglesa como "Russian Beads" ganham essa alcunha por serem obtidas em negociações com russos. Porém sua produção é alhures: obtidas pelos russos provavelmente em negociações com chineses, que por sua vez as 
obtiveram com comerciantes ingleses em Hong Kong, tendo os ingleses mesmos as obtido na região da Boêmia ou de Veneza (Dubin idem: 274; Karklins \& Sprague, 1972).

Assim, o encontro dos povos indígenas norte-americanos com as miçangas de vidro já é antecedido por um alto valor previamente atribuído às contas de variados materiais. Essa grande valorização pode ser vista especialmente nas relações estabelecidas durante as trocas de peles de animais. Na região da Baía de Hudson, por exemplo, extremo norte do continente, descreve-se que "A miçanga vermelha conhecida como Corneline d'Aleppo, ou "Miçanga da Baía de Hudson" para os comerciantes ao norte, implicava num valor de troca de 6 miçangas para uma pele de castor" (Dubin 1987: 274, tradução nossa) ${ }^{15}$.

Na região das Planícies, observava-se grande circulação de miçangas brancas, pretas e azuis. Dubin destaca que o debate em torno desses explicações pondera, por um lado, que essas três cores teriam sua produção menos custosa, sendo portanto mais vantajosas para eu europeus ou euro-americanos; por outro, eram também essas as cores mais valorizadas pelos povos indígenas, tanto pela raridade na obtenção local do azul, quanto pela proximidade dessas cores com aquelas utilizadas nos cintos wampum.

Os cintos wampum, assim como o chamado quillwork (bordado com espinhos de ouriço), trazem bons exemplos do lugar das contas e das miçangas entre os povos indígenas da América do Norte, de modo geral. A importância cerimonial dos cintos wampum, bem como de seus aspectos formais, nos indicam preferências indígenas que explicam o papel de destaque das contas nas relações entre indígenas e europeus ou euro-americanos. Já o modo como as miçangas passam a compor os bordados do quillwork nos mostra a potencialização que as mesmas podem dar a padrões estéticos já existentes.

\section{Wampum}

Os objetos feitos de contas de importância mais reconhecida na América do Norte indígena, são, sem dúvida, os cintos wampum, em especial entre os povos das planícies da costa Atlântica, como Iroqueses, Algonquinos e Cree. Compostos por contas feitas a partir de conchas sobretudo brancas, mas também de variados tons de púrpura, esses cintos conformavam desenhos geométricos que transmitiam mensagens, no mais das vezes relativas a tratados de guerra e de uso de território entre os diferentes povos da região. A decodificação

15 No original: The red bead known as corneline d'Aleppo, or 'Hudson Bay's Bead' to traders in the north, carried an exchange value of six beads to one beaver skin. 
das mensagens exigia a existência de experts responsáveis pela leitura dos cintos. Por se tratar de uma matéria-prima de difícil obtenção, grandes mobilizações eram feitas para sua aquisição.

Segundo Lainey (2008:400),

A palavra wampum é uma abreviação de wampumpeague ou wampumpeake, palavra em idioma algonquino do sul da Nova Inglaterra, recuperada pela língua inglesa do começo do século XVII, e que significava simplesmente "contas de conchas brancas enfiladas". (tradução nossa) ${ }^{16}$

Mas podemos salientar a descrição da utilização dessas contas desde Jacques Cartier, ainda no século XVI, que nomeou as contas de conchas brancas apreciadas pelos povos indígenas residentes no vale do rio Saint-Laurent (Québec, Canadá) de ensurgny (Noel, 1979:85).

Gray (2017) também salienta que, apesar do entendimento comum da língua inglesa da época indicar que wampum como um 'moeda' indígena, esta é uma acepção de dimensão muito diferente dos significados originais:

Ao contrário do que se crê popularmente, [o wampum] não era uma forma de "dinheiro indígena" anterior ao contato. Mais propriamente, servia como "adorno pessoal, uma forma de tributo, e um meio de assegurar um resgate. Apenas depois serviu como meio de troca". (Nassig 2004:342, apud Gray 2017:27, tradução nossa) $)^{17}$.

O reputado uso diplomático dos wampum se dava principalmente entre as três confederações indígenas do Nordeste Americano: Iroqueses, Andastes e Hurons, tendo seu uso se espalhado mormente com a dispersão deste último grupo para as regiões dos Grandes Lagos e do vale do rio São Lourenço por volta de 1650 (Lainey, 2008). Figuras formadas pelo uso das cores intercaladas conformavam mensagens transmitidas em momentos protocolares, comumente designando situações políticas, como acordos, guerras e uso de territórios.

O investimento de europeus na produção dos wampum denota que estes não subestimaram seu valor para os povos indígenas. Estabelecendo-se nas regiões onde as conchas Mercenaria mercenaria mais abundavam, há o registro de uma fábrica de wampum encerrando seu funcionamento no ano de 1917 (Dubin, 1987:271). Evidente que neste período os cintos também contavam com miçangas de vidro em sua composição (Fig. 5), já não tendo

16 No original: Le mot wampum est une abréviation de wampumpeague ou wampumpeake, em mot algonquin du sud de la Nouvelle-Angleterre récuperée par la langue anglaise au début du XVIIe siècle et qui signifierait tout simplement "enfilade de perles de coquillage blanc".

17 No original, It was not, contrary to a popular belief, a form of 'Indian money' prior to contact. Rather, it served as "personal adornement, a form of tribute, and a means to secure a ransom. Only later ir served as an exchange medium". 
o mesmo valor diplomático de outrora. Como destaca Gray (2017), atualmente, os wampum trazem para os povos indígenas contemporâneos outro principal valor: o da resiliência frente ao contato com os não-indígenas.

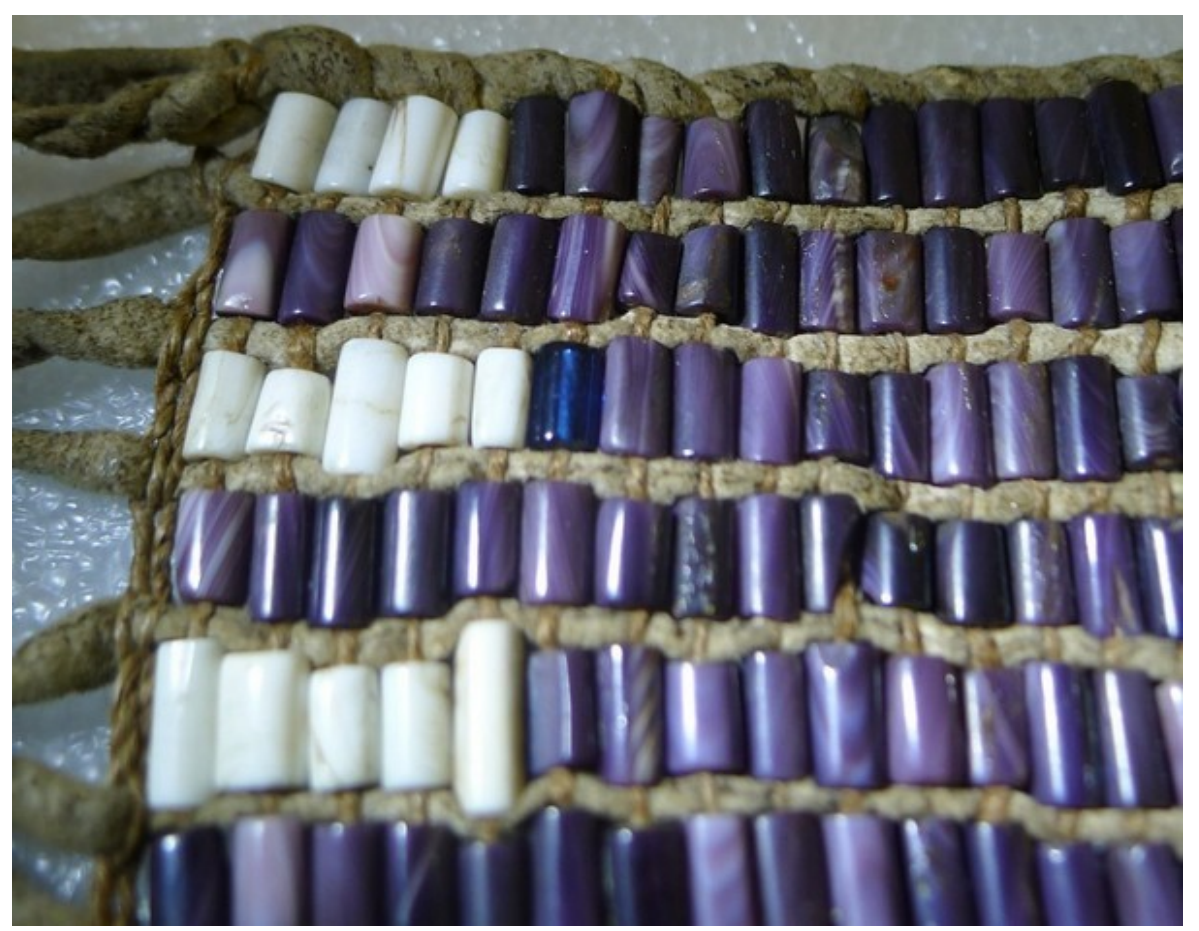

Figura 5: Detalhe de cinto wampum, datado do meio do séc. XVIII, apresentando uma única miçanga de vidro em meio à sua trama. Penn Museum (Filadélfia). Foto de Lise Puyo. Fonte: https://www.penn.museum/blog/museum/wampum-researchnotes-from-the-trail-june-2015/ [Acesso em 01 de outubro de 2019]

\section{Quillwork}

Se a introdução das miçangas na fabricação dos wampum colabora para a diminuição de seu valor diplomático, o mesmo não pode ser dito sobre o efeito das miçangas na indumentária ameríndia. Noël (1979) relata a explosão de cores e possibilidades figurativas que a chegada das miçangas, assim como de tecidos, botões e outros materiais, possibilitavam às artes vestuárias ameríndias no Québec, já nos séculos XVI e XVII. Como apresenta o autor, a produção de vestes, assim como de outros objetos tais cestos, bolsas e sapatos, era sobretudo de competência feminina, a partir das peles dos animais caçados pelos homens (exceto para os cestos, comumente feitos de entrecascas de árvores). 
Assim como em outras regiões do continente americano, mesmo os objetos de uso mais comum tendiam a apresentar decorações. No caso dos cestos e vestimentas ameríndios na região do Québec (séc. XVI e XVII), essa decoração acontecia sobretudo por meio de duas técnicas: (1) incisões; e (2) bordados, feitos especialmente com a aplicação de espinhos de ouriço - o quillwork.

Técnica eminentemente ameríndia, o quillwork apresentava (e apresenta) variados estilos, conforme os diferentes povos indígenas. As diferenças mostravam-se especialmente em relação aos estilos de bordados e as cores utilizadas no tingimento dos espinhos. A familiaridade experimentada pelas mulheres na decoração de objetos por meio da aplicação desses espinhos fez com que as contas de vidro tenham sido rapidamente incorporadas para este uso (Figura 6).

Dubin (1987) salienta os povos das Planícies como exímios artesãos de miçangas - ou antes, suas mulheres como habilidosas artesãs e os homens como grandes apreciadores. Um dos destaques são os mocassins com bordados que poderiam vir desde as solas até o alto dos sapatos, refletindo a luz do sol durante travessias de desertos e campos abertos, principalmente pelos Crow. Nos funerais, havia os spirit mocassins, cujas solas seriam inteiramente bordadas com miçangas (Dubin 1987:284). Também as selas dos cavalos apresentavam profusas decorações em miçangas. No sul do Canadá, os Métis trabalhavam misturas de padrões europeus florais com técnicas ameríndias de aplicação de contas, destacando os usos das miçangas.

Atualmente, as miçangas seguem em alto apreço pelos povos indígenas da América do Norte, como se pode apreciar nas festas de Pow Wow, em que a riqueza estética dos atuais usos encontra especial destaque. O conjunto de vestes, sapatos e acessórios que compõe a indumentária dos dançarinos de Pow Wow é chamada de Regalia, sempre com ricas decorações em miçangas.

Gray (2017), não só enquanto pesquisadora, mas também como artesã Anishnabee, salienta que "Regalia is not just for this dimension, it transcends time and waking reality." (p.20). Segundo a autora, as cores e os padrões dos bordados têm íntima relação com sonhos e espíritos ancestrais. Esta é uma das maneiras pelas quais a autora entende que a resiliência é o que marca a expressão atual dos povos ameríndios em seus trabalhos com miçangas (Figura 7). 


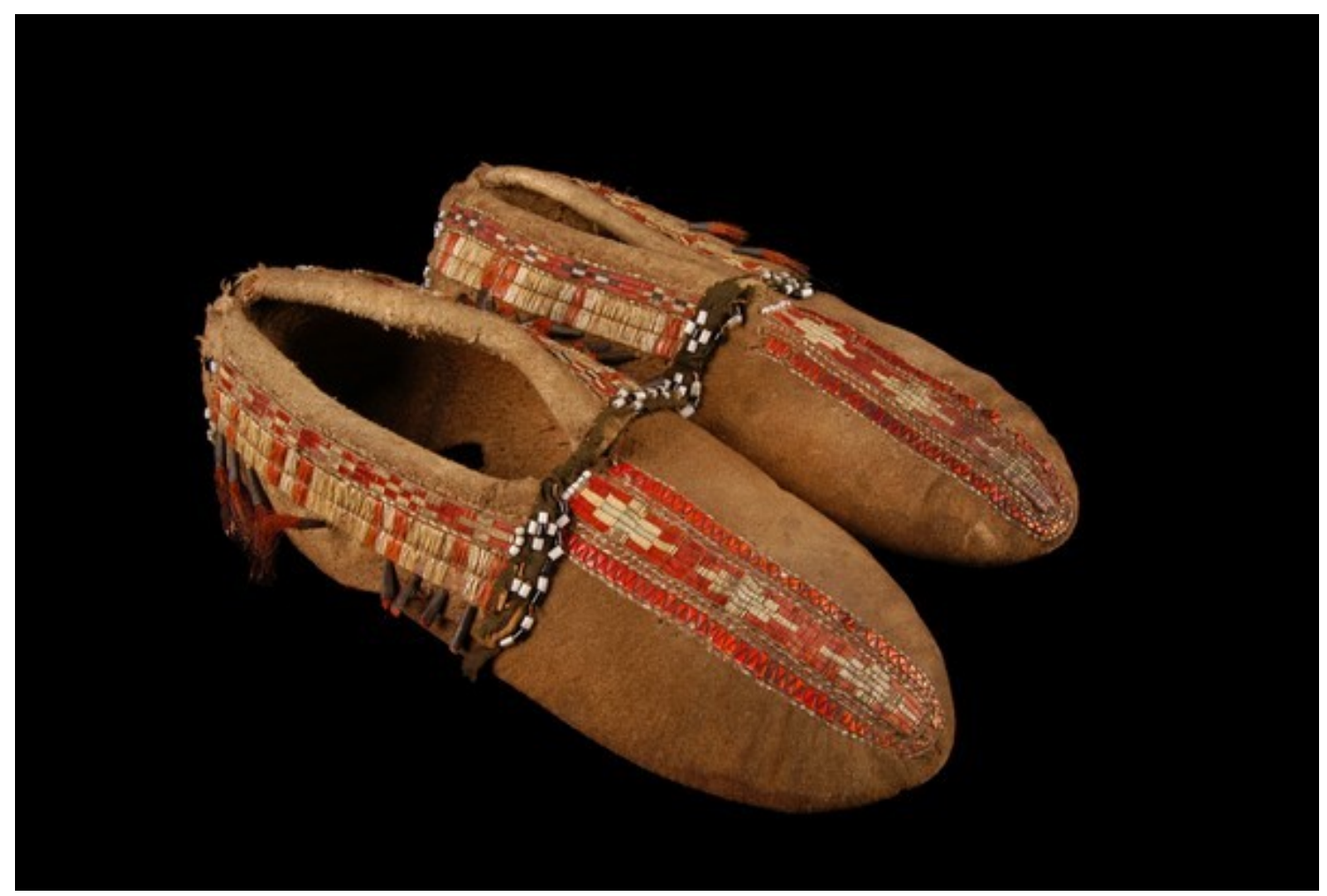

Figura 6: Par de mocassins Haudenosaunee ou Wyandot, datado de meados de 1780. Pele de cervo, espinhos de porco-espinho, miçangas cilíndricas, couro, metal, entrecasca de carvalho, tecido. Coleção do Musée du Quai Branly, n. de inventário: 71.1909.19.61.1-2 Am D. http://www.quaibranly.fr/fr/explorer-les-collections/base/Work/action/show/notice/314379-paire-democassins/page/1/ [Acesso em 01 de outubro de 2019]

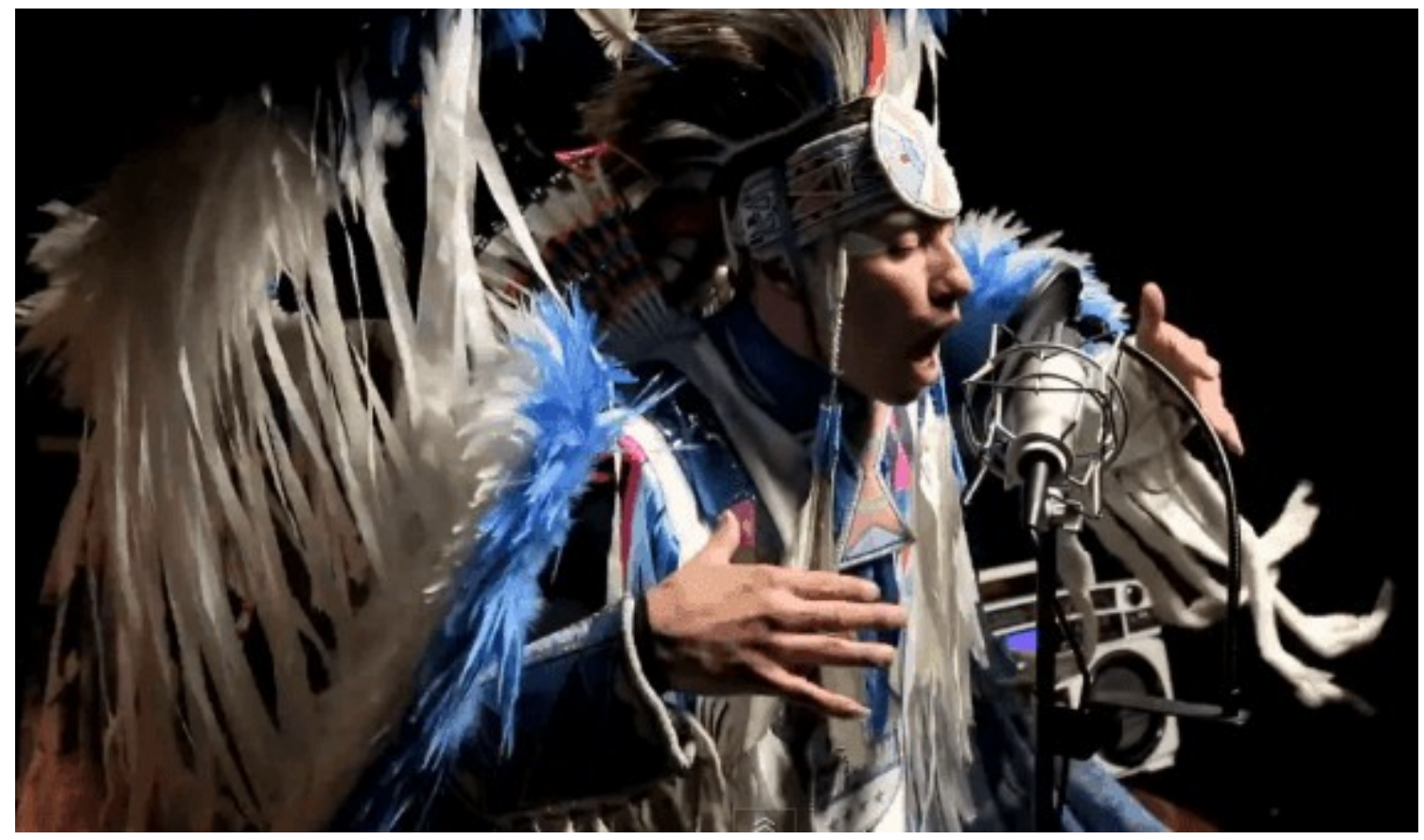

Figura 7: O rapper crow Supaman apresenta-se sempre com suas roupas de Regalia, com detalhes em miçangas no adereço de cabeça, nas mangas, no peito. Fonte: https://www.powwows.com/supamans-fansknow-his-passion-for-music-but-he-has-another-passion-powwows/ [Acesso em 01 de outubro de 2019] 


\section{Miçangas e Povos Indígenas nas Terras Baixas da América do Sul}

Vimos acima que as miçangas logo entraram no gosto dos povos indígenas da América do Norte, potencializando padrões estéticos já existentes. O mesmo pode ser dito para os povos indígenas da América do Sul, que, a partir de seus variados estilos, apropriam-se há séculos do material, também nessa movimentação de potencializar seus próprios padrões estéticos. Isso implica dizer que não apenas os adornos superlativam-se com as cores e quantidades de miçangas, mas também técnicas e outros saberes, como cantos e narrativas, encontram nas miçangas fecundidade para seu desenvolvimento.

Bandoleiras, colares, perneiras, testeiras, pulseiras - esses e tantos outros adornos já eram largamente utilizados pelos variados povos da América do Sul desde antes da chegada dos colonizadores. Comumente feitos de materiais resistentes, como pedras, ossos, dentes, conchas e sementes tratadas, a mensagem mais evidente passada pelo uso desses adornos é a alta valorização das contas por esses povos. Também em relatos que tratam de suas cosmologias, existem diversas imagens de fios pelos quais são ligados espíritos e conhecimentos, entre diversos povos, como os Wajãpi no Amapá (Gallois, 1984), os Ye’kuana (Gongora, 2017) e os Yanomami (Kopenawa \& Albert, 2014), na fronteira do Brasil com a Venezuela, os Mamaindê no Brasil Central (Miller, 2007).

Não é à toa que a centralidade da fabricação do corpo continua sendo um paradigma importante para as discussões da etnologia ameríndia (Seeger et alli, 1979), agora unindo-se às discussões que destacam o papel dos objetos nessas cosmologias (Van Velthem, 2003, Ewart, 2007), sejam eles produzidos nas cidades ou pelos próprios povos indígenas. O que as investigações têm mostrado é que, muitas das vezes, nas cosmologias ameríndias, corpos hoje vistos como não-humanos já foram humanos nos tempos primevos, de que falam os mitos, e que os saberes relacionados à produção industrial foram ou perdidos por esses povos, ou por eles preteridos em relação a outras tecnologias. Essas transformações, como se sabe, têm sido abordadas na literatura especializada, como tema da má escolha.

Entre os Shipibo-Konibo, grupo indígena falante de língua pano, que habita a região da bacia do rio Ucayali, na Amazônia peruana, a estética ocupa papel de destaque, com características bem marcantes e facilmente reconhecidas da sobreposição de desenhos que repetem padrões gráficos como gregas e zigue-zagues, tanto em cerâmicas quanto em bordados. Belaunde (2016) traz um panorama do uso e do lugar das contas para eles, 
destacando o século XIX como momento da chegada de maiores quantidades de miçangas, conforme os colonizadores intensificavam a exploração dos seringais.

A percepção de que a chegada das miçangas foi acompanhada de doenças e outras desestabilizações também é frequente. Os Desana (Alto Rio Negro) relacionam as miçangas à origem de doenças infecciosas vindas com os colonizadores, em especial varíola e rubéola, marcadas pelo forte contágio e morbidez (Buchillet 2002). Segundo sua percepção, a aparente imunidade dos brancos a essas doenças seria prova de seu poder sobrenatural, assim como serem numerosos, seu domínio técnico, opulência e riqueza.

Semelhante percepção é veiculada pelos Marubo, conforme relato de Varin Mena Marubo (2016), que traz duas origens das miçangas. A primeira delas conta de um grupo de caçadores que encontra uma aldeia abandonada, repleta de miçangas espalhadas pelo chão, que teria sido abandonada pelos Osho Nawa, povo de pessoas muito bonitas, mas que matavam aqueles que não tivessem seu mesmo padrão estético. A segunda narrativa de origem das miçangas é relacionada ao pajé Mëni:

\begin{abstract}
Este pajé tão especial foi quem mostrou, pela primeira vez, a miçanga aos Marubo, materializou-a em suas mãos num colar de várias voltas, dizendo: "as novas gerações irão viver essa era obcecada pela miçanga, farão de tudo para possuí-la em suas vidas, com isso haverá entre as mulheres raiva, rancor, inveja, cobiça e falsidade, as mulheres empobrecerão suas mentes, os costumes de suas artes só viverão nas mentes daquelas que tentarão resistir a essa nova era, as artes proibidas prevalecerão, como a txakiri (miçanga) (...). Junto com essa novidade virão seus efeitos negativos: tosses, irritações na pele e, como não vai ser só esse material, virão também várias outras doenças desconhecidas ao longo do tempo. (p.102)
\end{abstract}

Entre as mulheres Tiriyó, Katxuyana, Txikiyana, Wayana e Aparai, os sentimentos de inveja e de ciúme costuma acompanhar a entrega de miçangas, que deve sempre ser feita em local reservado, com as miçangas sendo transportadas fora do alcance dos olhos de outras pessoas. Já a conexão entre miçangas e doença/saúde, apesar de não ser enfatizada, pode ser sutilmente percebida na intenção de proteção e de cuidado quando uma mulher presenteia alguém com os adornos por ela feitos. A descrição abaixo, mesmo se referindo aos ShipiboKonibo, ressoa com o caso do sudeste guianense:

Junto às suas mães, as meninas se iniciam na arte de embelezar o mundo e de comunicar afeto, proteção e desejo por meio da manufatura de objetos e corpos cobertos com desenhos. Elas dão continuidade às técnicas de suas avós e, ao mesmo tempo, criam novas técnicas e motivos adaptados aos novos materiais, acessíveis graças ao enfrentamento, as trocas e as relações de poder estabelecidas com outros povos indígenas e colonizadores. A arte de kene foi sempre política (Belaunde, 2012, Valenzuela e Valera 2005, apud Belaunde 2016:96) 
Retomando as narrativas marubo acima citadas, temos relações de miçangas tanto com outros magnificados esteticamente (os Osho Nawa) quanto com os conhecimentos acessíveis aos pajés. A materialização de colares de voltas também é descrita entre os Mamaindê (Miller 2007), e a imagem das linhas ou fios com pedras brilhantes materializando conhecimentos xamânicos encontrada entre os Ye'kuana (Gongora, 2007) e Wajãpi (Gallois, 1984). Conforme apresenta Kopenawa (Kopenawa \& Albert 2014), as miçangas são utilizadas para imitar os adornos dos espíritos, sendo elas mesmas fabricadas, no tempo mítico, por mulheres que desceram do céu com elas. Essas primeiras miçangas seriam os filhos dessas mulheres.

A origem exógena das miçangas, por sua vez, provoca diferentes efeitos nos povos ameríndios das Terras Baixas da América do Sul. Entre os Kayapó (Lagrou, 2016), cujos adornos tradicionais possuem o uso extremamente restrito, as miçangas "democratizam" o uso para além das prescrições, afinal não pertencem, de saída, a ninguém. Em outros casos, como entre os Rikbatsa, as miçangas exigem processos que ficaram conhecidos na literatura antropológico como "pacificação" (Albert \& Ramos 2002). Procedimentos estes que visam amansar as potências perigosas do que é belo e de origem exógena - no caso Rikbasta, as miçangas não são usadas em profusão em nenhum ornamento, sempre participando de composições com uso de sementes.

Entre os Krahô, miçangas e sementes também possuem circulações específicas. A semente principalmente usada por esse povo do Brasil Central é a tiririca, que possui tamanho e formato muito semelhante ao das miçangas $9 / 0$, as mais utilizadas pelos povos indígenas das Terras Baixas da América do Sul. Conforme descreve Amorim (2016), em suas comunidades, a preferência é pelo uso de miçangas, estando as peças feitas em sementes principalmente voltadas para o público não-indígena. $\mathrm{O}$ mesmo movimento é observado entre as mulheres Tiriyó e Katxuyana, que consideram a utilização de miçangas na fabricação de suas saias frontais (keweyu) mais antiga do que o uso de sementes de maramara, feito sobretudo para agradar o público não-indígena, que considera mais legítimo o artesanato indígena feito a partir de matérias-primas existentes nos ambientes da região (Grupioni et allii, 2007:11). Como temos apresentado, e aprofundaremos a seguir, esse tipo de preconceito em nada condiz com as concepções e percepções indígenas acerca da "tradicionalidade" da miçanga. 


\section{Apropriação e circulação das miçangas na Guiana Indígena}

Em relação à chegada das miçangas entre os povos indígenas guianenses, não há evidências arqueológicas que indiquem data, tipo ou proveniência das mesmas na região. Nos diários do Padre Jean de la Mousse (de la Mousse \& Colomb, 2006), datados do século XVII, já há a menção das rassades, mas não podemos inferir que esse material seja uma novidade para os povos da época, já sendo inclusive um material valorizado, e muito utilizado em trocas inusitadas: em diversas passagens de seus diários, o padre presenteava os indígenas que soubessem seu catequismo com as tais contas de vidro. Em consonância com essa presença do século XVII das miçangas na região, há a informação encontrada em Schoepf (1976:57) da existência de uma tanga de miçangas proveniente da região em museu europeu neste mesmo século.

Esses relatos do Padre Jean de La Mousse interessam ao presente estudo por atestarem a antiguidade das redes de relações entre os povos indígenas guianenses. Se consideramos também os relatos feitos por Crevaux no final do século XIX (1883), é possível perceber não só as constantes relações entre povos indígenas (e entre indígenas e não-indígenas) como também as especificidades dos modos de fabricação e valoração estética desses povos ao longo de, pelo menos, três séculos. Também é interessante notar que, assim como na América do Norte, as miçangas não chegam sozinhas, mas em meio a diversos outros menus objets, como menciona diversas vezes Crevaux: agulhas, botões, sininhos, guizos, tecidos. Esse material prontamente cai no gosto dos povos ameríndios, não sendo poucas as transações envolvendo-os entre europeus e ameríndios, encaradas de modo bastante diferente por cada uma das partes, conforme já visto acima.

Padre Jean de la Mousse foi um jesuíta que andou pela região litorânea dos atuais Suriname e Guiana Francesa entre os anos de 1684 e 1691. Embora nem todos seus relatos tenham chegado aos dias de hoje (um dos diários tendo sido perdido), suas descrições seguem sendo referências tanto etnográficas a respeito das populações nativas do século XVII (especialmente os Galibi) quanto do espírito da época, trazendo uma narrativa espirituosa, repleta das contradições do trabalho colonizador de conversão que o padre desenvolvia entre povos pelos quais também sentia admiração.

Acompanhando os relatos de Jean de la Mousse, diversas imagens compõe o livro, permitindo uma apreciação estética que nos indica recorrências marcantes ainda nos dias 
atuais, como é o caso da prancha que mostra um couyu (Fig. 8), tanga feminina, chamada atualmente de keweyu (Fig. 9) nas línguas tiriyó e waiwai, weju em wayana e aparai, monenoho em katxuyana. Essa peça é a que melhor representa o trabalho com miçangas das mulheres karib guianenses.

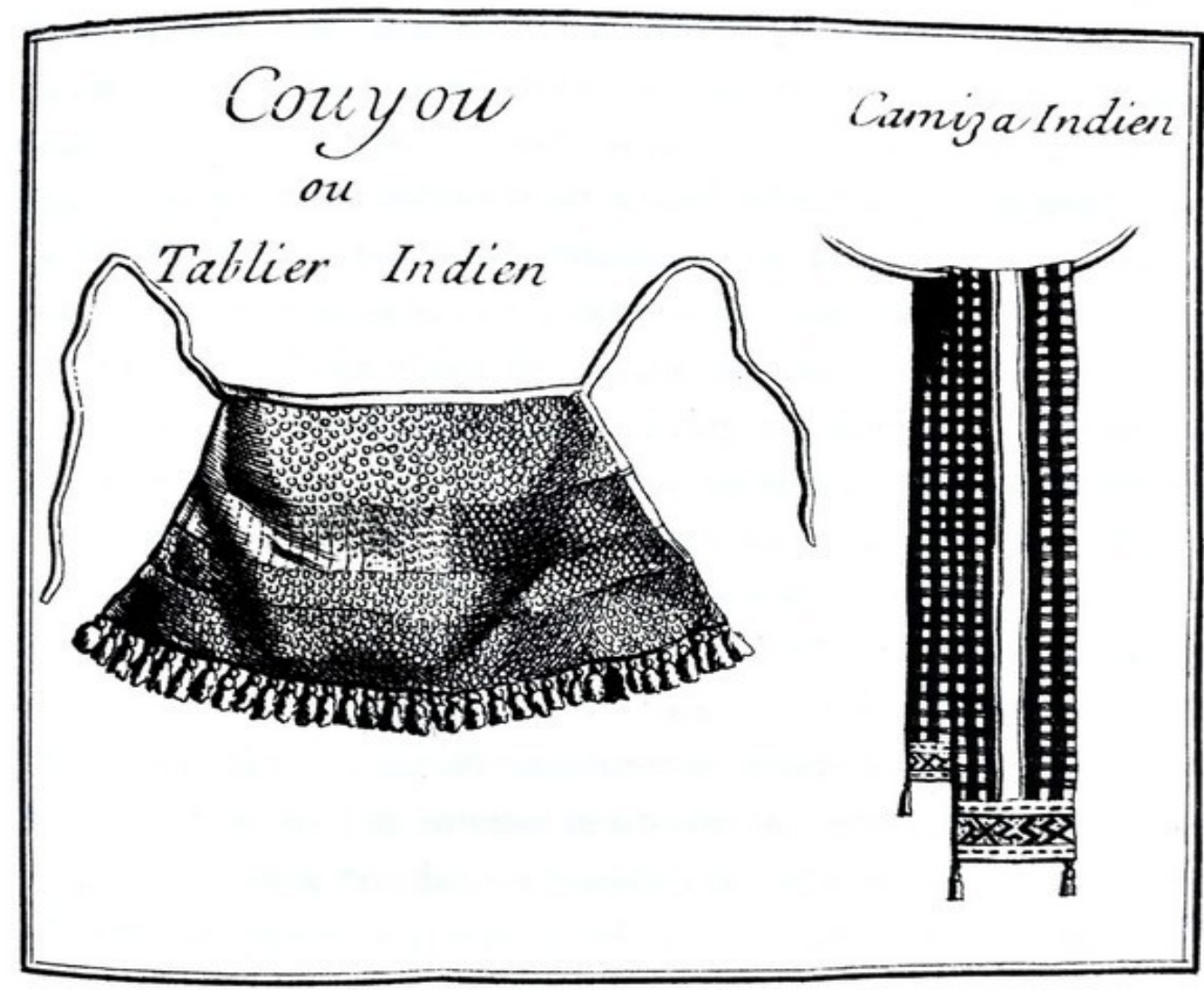

Pierre Barrère

Nouvelle relation de la France Equinoxiale, contenant la description des côtes de la Guiane, de l'üle de Cayenne...

Paris, Piget, Damonneville et Durand, 1743.

Figura 8: "Couyou" e "Camiza". Fonte: La Mousse \& Collomb 2006 


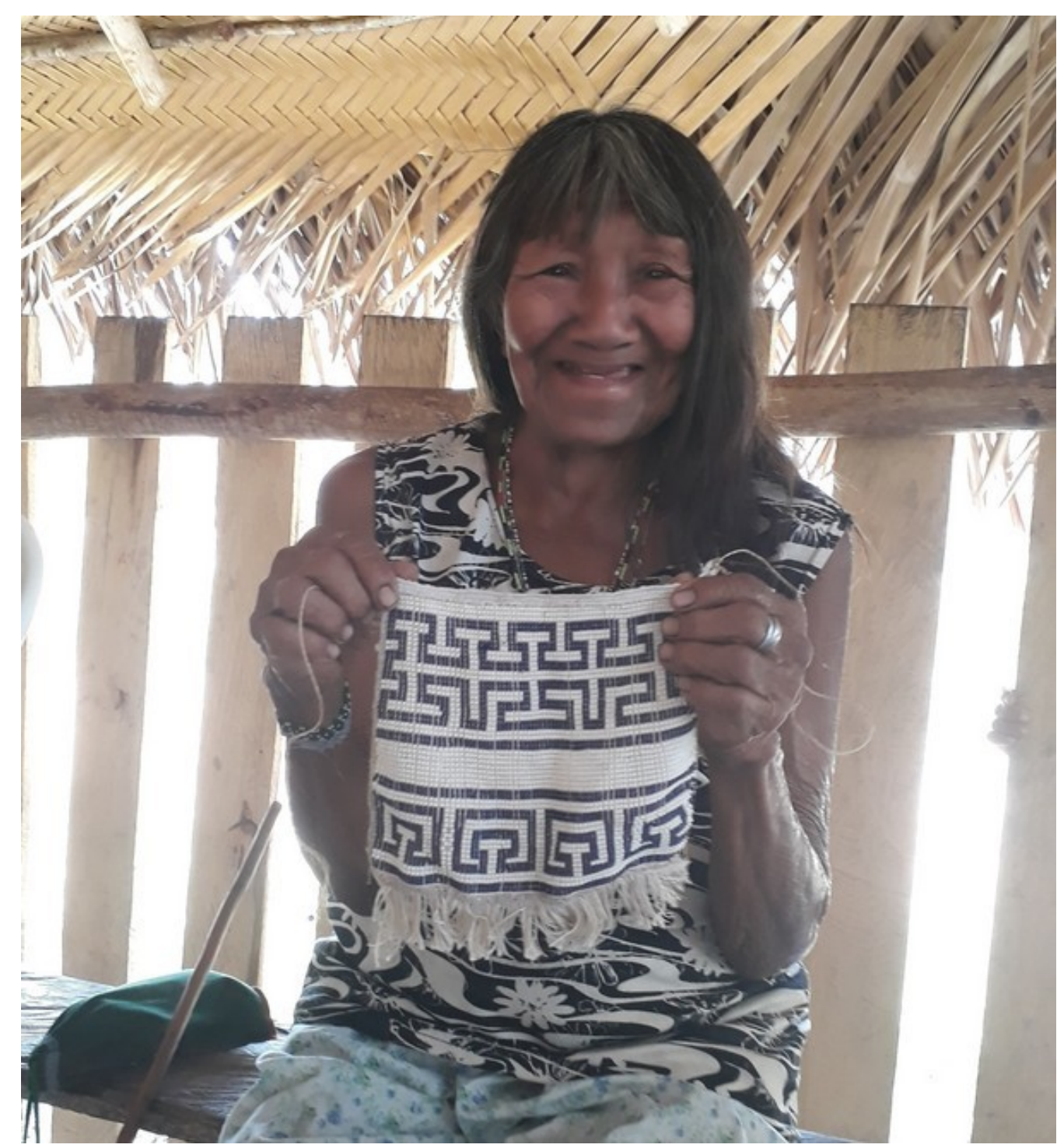

Figura 9: Catarina Tiriyó nos mostra o keweyu que fez. Aldeia Missão Tiriyó, abril de 2019.

Ao longo do desenvolvimento deste trabalho de mestrado, pude apresentar minha pesquisa em diversas aldeias (Missão Tiriyó, Orokofa, Tuhaentu, Ponoto e Bona) e também para mulheres tiriyó, katxuyana, wayana e aparai, na cidade de Macapá. Para tanto, elaborei uma apresentação de slides em que expunha objetivos e etapas da pesquisa, além de algumas imagens previamente coletadas. Dentre essas imagens, além da mencionada prancha de Jean de la Mousse, há outra, retirada do livro de Crevaux (1883), que mostra uma casa galibi 
repleta de objetos, dentre os quais uma dessas tangas ou saias frontais, bancos de madeira e outros artefatos (Figura 10).

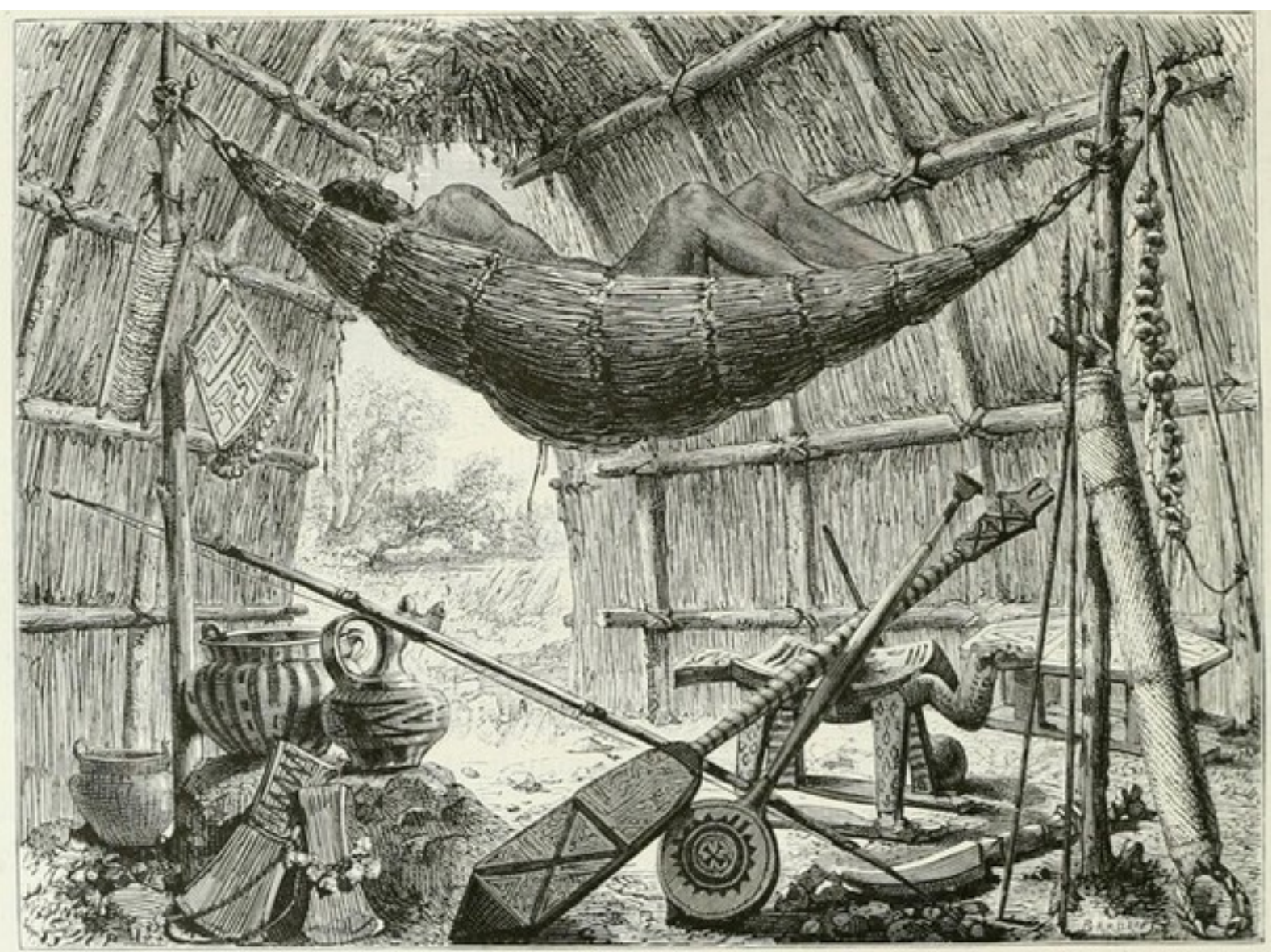

Figura 10: Casa Galibi, com diversos objetos, incluindo uma tanga, possivelmente feita de miçangas, ao lado esquerdo da rederevaux 1883:12. Disponível em: https://archive.org/details/voyagesdanslam00crevuoft/page/11 [Acesso 01 de outubro de 2019]

Essa prancha retirada do mencionado livro de Crevaux despertava especial interesse dos presentes pela quantidade de objetos nela dispostos. O público que comparecia nessas reuniões de apresentação dessa de pesquisa era composto principalmente por mulheres, que junto consigo também traziam diversas crianças. Pessoas mais velhas, tanto homens quanto mulheres, também compareciam, assim como os chefes e lideranças das aldeias em que fiz as apresentações.

Esse público diverso permitia também que as conversas a respeito das imagens trouxessem comentários variados, muitos deles tecidos acerca da beleza dos objetos, bem como de sua utilidade. Eu mesma aproveitava a situação para perguntar a respeito da origem 
dos objetos ali dispostos, notando que esse tipo de questão não era exatamente central nas conversas indígenas, que se interessavam mais pelos usos, materiais e modos como os objetos poderiam ter sido feitos, comentando também sobre histórias e locais onde os mesmos foram vistos.

Os comentários de meus interlocutores sobre a provável origem dos objetos dispostos na figura são interessantes. Segundo eles, poderiam ser tanto dos próprios Galibi quanto de outros povos. Merekuku Apalai, por exemplo, respondeu: "Não sei... Eles podem ter trocado, né?”. Uma casa repleta de objetos denota riqueza não apenas pela quantidade de objetos que há dentro dela, mas, principalmente, pela evidência das muitas relações tramadas para que fosse possível a aquisição de tantos objetos variados. Análoga a essa situação, temos a explicação que Kasiripinã Wajãpi dá para Dominique Gallois (comunicação pessoal) em relação ao seu grande conhecimento de composições de padrões gráficos: por ter viajado muito, Kasiripinã pôde estabelecer diversas relações e conhecer muitas outras gentes e seus modos de se pintar.

Com a crescente sedentarização dos povos da região, os movimentos e trocas não acontecem mais dessa mesma maneira, embora sigam tendo grande importância, conforme podemos perceber pelo uso intenso de aplicativos de compartilhamento de arquivos nas terras indígenas, onde não há sinal de celular, nem conexão com a internet. $\mathrm{Na}$ próxima seção, apresento alguns aspectos importantes relacionados à circulação de miçangas e de adornos através de trocas na região, conforme apresentado pela literatura antropológica.

\section{Trocas}

Há pouco mais de uma década, ocorreu um acalorado debate antropológico (Rivière et allii 2007) em torno da imagem que as sociedades indígenas das Guianas conformam de suas relações intercomunitárias. Um dos lados do debate (Rivière 1984) descreve as sociedades indígenas da região como marcadas pela endogamia local, com limitadas relações com o exterior. O outro lado, com o qual me alinho, entende que, para bem se compreender a região das Guianas, é preciso superar recortes localistas ou étnicos, atentando para as extensas redes de relações (Gallois, 2005). Desta feita, a imagem de sociedades atomizadas deixa de ser o "tipo ideal" da região, posicionando-se enquanto evento histórico que integra os mecanismos 
da organização social regional. Ainda que este não seja o foco desta pesquisa, acredito que será possível perceber esse movimento ao longo das descrições que apresentarei.

Conforme argumentam os autores alinhados neste segundo lado, a imagem de grupos endogâmicos só é possível ao se abstrair sociodiversidade local, "escondida" sob os etnônimos cristalizados a partir das relações com as sociedades nacionais, quando os etnólogos desse primeiro grupo do debate faziam seus trabalhos de campo. Grupioni (2002, 2005) demonstra como a alteridade é fundamental nos casamentos da região, como já se podia perceber em escritos de Frikel (1972), ao indicar os diferentes -yana em esquemas genealógicos. -Yana é um sufixo presente nas línguas karib da região que pode ser traduzido como "gente" (outros sufixos que possuem a mesma designação são -ó, -koto), sempre antecedido de nomes de animais (como ewarhoyana: gente-anta, akuriyó: gente-cutia), de espécies vegetais (pïrouyana: gente-flecha) ou ainda nomes de rios e igarapés (Katxuyana: gente do rio Katxuru/Cachorro, Kahyana: gente do rio Kahu/Trombetas).

As diferentes gentes espalhavam-se por toda a região referida até a década de 1960, quando passaram a ser atraídas e/ou conduzidas para grandes aldeamentos ligados sobretudo a missões cristãs evangelizadoras, trazendo outra configuração para a organização social desses povos, como é possível perceber pelos mapas elaborados por Protásio Frikel (1971) (Fig. 11).

Grupioni (2002) mostra como os grupos se organizam a partir de movimentos de dispersão e concentração, típicos da região. Essa movimentação acontece por diversos fatores, como a disponibilidade de peixe, de caça e de locais para fazer roça, questões de convívio na aldeia, possibilidades de casamento, guerras. A fundação de um novo local de moradia, pata (em língua tiriyó), de modo geral, mobiliza um casal, suas filhas solteiras, suas filhas casadas e seus maridos, seus filhos solteiros, e os peitoton (forma plural; forma singular peito) do pataentu (literalmente, 'fonte', 'matriz' desse novo local de moradia), isto é, seus aliados, como cunhados e irmãos.

Assim, é comum que as aldeias não ultrapassem a população de cerca de 20 a 40 pessoas - o que contrasta enormemente com os grandes aldeamentos como a Missão Tiriyó, onde convivem cerca de 600 pessoas. Também a leitura das crônicas dos viajantes dos séculos passados traz esses contrastes demográficos, como mostrou Rivière (1963): ao mesmo tempo em que há relatos de aldeias pouco populosas, há também registros de grandes concentrações populacionais. 

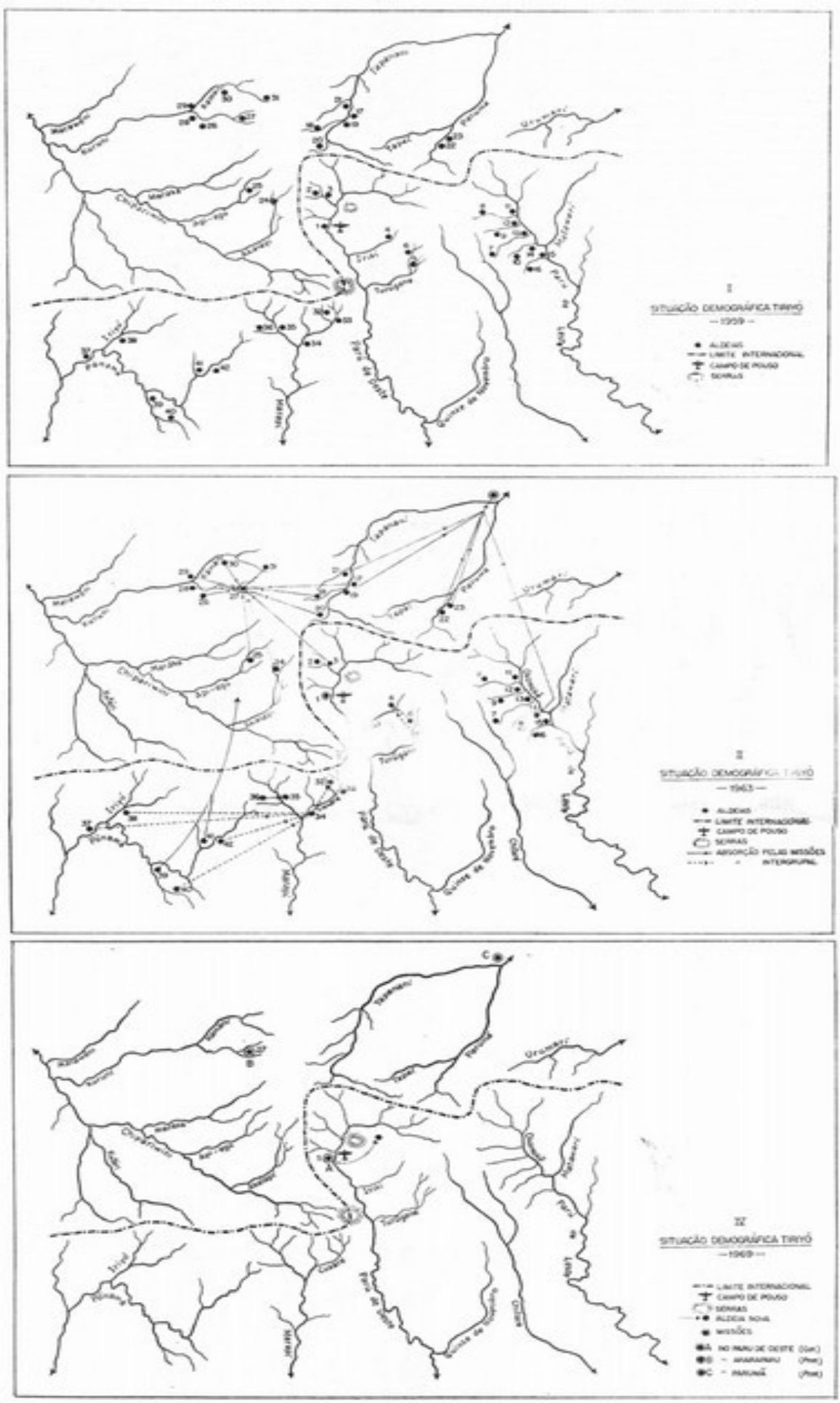

Figura 11: Mapas que mostram a situação pré-concentração nos aldeamentos missionários no Brasil e no Suriname. Frikel 1971: 37, 39, 42. Disponível em: https://repositorio.museugoeldi.br/handle/mgoeldi/895 [Acesso 01 de outubro de 2019] 
Note-se que mesmo nas discussões da Arqueologia sobre a ocupação do escudo das Guianas o debate das trocas mostra-se como um paradigma sendo modificado. Cabral (2011) traz um breve panorama das discussões arqueológicas acerca da Fase Koriabo, encontrada em sítios por toda a região, desde a Guiana até o Amapá, contemplando também a fronteira entre Suriname, Guiana Francesa e Brasil. O que nos interessa nessas discussões é menos os caminhos que as diferentes culturas podem ter feito ao longo do tempo do que a evidência das relações de troca ocorrendo entre os mais diversos grupos, em toda a extensão da região.

Apostando na cooperação com as comunidades que vivem nas mesmas regiões dos sítios arqueológicos (no caso estudado por Cabral, um dos sítios é dentro da Terra Indígena Wajãpi), a arqueóloga destaca uma observação do chefe Waiwai Wajãpi sobre os cacos encontrados em sua terra não serem dos Wajãpi por não reconhecerem seus desenhos. Esta observação trazida por Cabral (2011) remete imediatamente a diversas situações que pude presenciar nas aldeias pelas quais tenho circulado, onde é frequente o encontro com peças de cerâmicas variadas. Honório Kaxuyana, um senhor reconhecido pelos seus conhecimentos, referiu-se a esses fragmentos de cerâmica, em língua portuguesa, como "caquinhos do passado", enquanto caminhávamos sobre uma grande quantidade deles, na aldeia Santidade, às margens do rio Katxuru. As evidências de que esta aldeia já foi ocupada em outros momentos não se bastam aos caquinhos do passado: muitas são as narrativas que mencionam sua ocupação, com outros nomes, e há muitos mamoeiros e pés de batata-doce considerados como "deixados pelos antigos".

A separação entre momentos de uso mais restrito e de circulação dos objetos acontece apenas para fins de análise, visto que nas narrativas coletadas ao longo do trabalho de campo é evidente que essa circulação implica nos usos e nas apreciações estéticas feitas pelas pessoas envolvidas. Não se troca tudo por qualquer coisa. Na cena descrita por Søderberg (1994:64, apud Kieffer-Døssing 2016:32), uma moça katxuyana chega a derramar uma lágrima ao trocar seu monenoho (tanga) por certa quantidade de miçangas. Após o episódio, Søderberg deixa de adquirir essas tangas, embora não fique claro se por conta de seu alto valor de troca ou de apego indígena por esse tipo de peça. As miçangas que circulam têm sempre cores, formatos e tamanhos, não apenas certos indivíduos entregando-as para outros indivíduos. Nos diferentes rios que cortam a Guiana Indígena em sua porção brasileira, temos variadas narrativas a respeito da chegada das miçangas para esses povos. 
Num breve encontro às margens do rio Jatapu, no local onde a construção da BR 210 é interrompida na divisa com a Terra Indígena Trombetas-Mapuera (porção roraimense), o senhor Bernaldo Piiti, chefe da aldeia Samaúma, e pai de Fernandinho Waiwai, atual presidente da APIW, me contou que quem havia trazido miçangas para seu povo eram os Tiriyó. Alguém que não esteja familiarizado com o histórico e a sociodiversidade guianense, acharia a declaração sem sentido. Isto porque a identificação oficial desse senhor é Waiwai, morador do estado de Roraima, e os Tiriyó encontram-se no norte do Pará, já próximos ao Amapá.

Contudo, o senhor Bernaldo Piiti se reconhece enquanto Katuena, e nasceu na região relacionada a esse -yana, nas cabeceiras do rio Trombetas, já em território próximo à região habitada atualmente pelos Tiriyó. Além disso, conforme apontam os dados genealógicos que estão sendo colhidos no âmbito das discussões do desenvolvimento do Plano de Gestão Territorial (PGTA) da região, as cabeceiras do rio Trombetas tiveram suas populações dispersas tanto em direção à aldeia Kanashen (donde marcadamente a denominação Waiwai se espalhou), na Guiana, quanto à Kwamala e demais aldeias dos arredores, no Suriname (donde marcadamente espalhou-se à denominação "Tiriyó", juntamente com a aldeia Missão Tiriyó e seus arredores, no lado brasileiro).

Assim, a narrativa de Bernaldo nos mostra que apesar da grande distância que hoje separa as aldeias de predominância waiwai daquelas de predominância tiriyó, as redes de relações entre esses povos são antigas - no caso, anteriores aos movimentos de concentração nos aldeamentos missionários - e mobilizadoras tanto de trocas materiais (objetos como miçangas) quanto imateriais (saberes a elas vinculados, como técnicas de tecelagem e padrões gráficos).

Essas redes de trocas de objetos da região, com especial foco nas relações estabelecidas pelos Wayana e Aparai, estão detalhadamente descritas na dissertação e na tese de Gabriel Coutinho Barbosa $(2002,2007)$. Entre os Tiriyó do rio Paru de Oeste, chama atenção à unanimidade em mencionar que as miçangas vieram dos Mekoro, sendo trocadas sobretudo por cachorros. Sobre os cachorros, a história é que eles eram das Cobras Grandes, tendo aparecido nas aldeias vindos das água. Hoje em dia, muitos cachorros são trazidos das cidades, em especial de Macapá. Num relato de Barbosa (idem), ainda em 2007, as trocas entre Tiriyó, Aparai, Wayana e Mekoro envolviam cachorros, sendo que, segundo esse mesmo autor, essas trocas remontariam ao final do séc XVIII, envolvendo tanto ameríndios quanto 
não-indígenas. Apesar de serem um bem de troca requisitado, o tratamento dispensado aos cachorros por esses povos, assim como por tantos outros, é de desprezo: desde cedo as crianças aprendem a chutá-los, e sua alimentação costuma restringir-se a eventuais restos das refeições. Isso faz com que boa parte desses animais sejam criaturas magras, doentes e desconfiadas, mas que estão sempre pela aldeia. Os cachorros mais bem apreciados por seus donos, por sua vez, recebem nome e gozam de melhor alimentação.

A seguir, copio o diagrama desenvolvido por Barbosa (2007:87) para ilustrar a circulação de cães (Figura 12), tendo em mente que, ao menos para os Tiriyó, estes eram frequentemente trocados por miçangas.

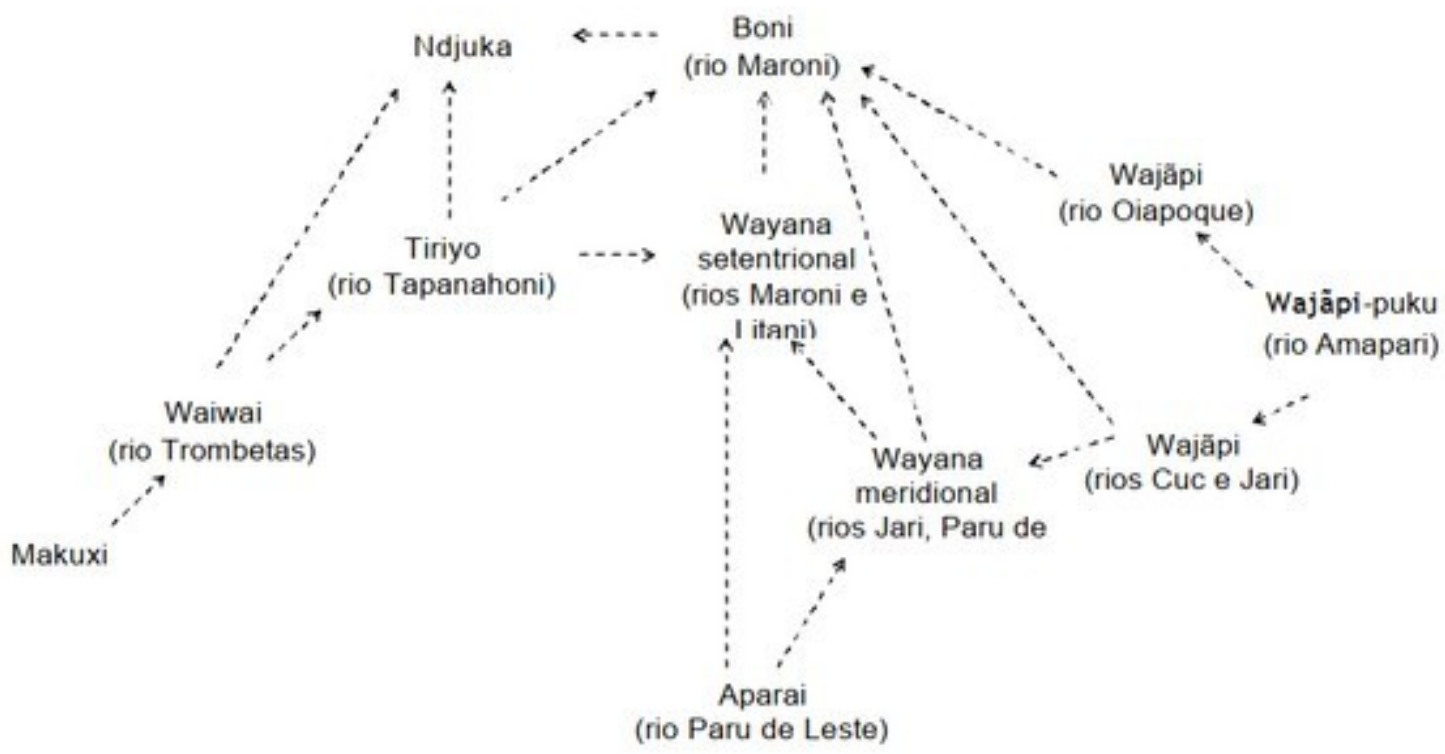

Figura 12: Fluxo de cães entre meados dos séculos XVIII e XIX. Barbosa 2007:87.

Diakui Sora Tiriyó, técnica de saúde indígena, cuja mãe é Aramiso e o pai é Sakëta, fez para mim uma breve cronologia a respeito das miçangas entre os Tiriyó. Segundo ela, primeiramente, as miçangas eram trazidas pelos Mekoro em fios de miçangas não misturados; em seguida, os freis franciscanos passam a fornecer eles mesmos as miçangas, já em sacos (é dito que os freis não gostavam que os Tiriyó estabelecem relações com os Mekoro); o próximo momento é a entrada das "miçangas ruins ${ }^{18 "}$ " pelo Suriname; em seguida, houve um

18 Conforme será detalhado no capítulo seguinte, as miçangas apreciadas, "miçangas verdadeiras" são aquelas de formato regular e que não desbotam com o tempo e o uso, em contraste com as miçangas ruins, que possuem irregularidades tanto em seu tamanho (fazendo com que as peças fiquem tortas) quanto em seu orifício (dificultando a passagem da agulha e, portanto, a feitura das tramas), além das cores que desbotam. 
momento de grande falta de miçangas, segundo ela, por volta dos anos 1990, quando os freis pararam de trazer miçangas; o movimento seguinte digno de nota em relação à vinda de miçangas foram os projetos trazidos por Denise Fajardo Grupioni ${ }^{19}$.

Em maio de 2018, numa oficina realizada com mulheres na aldeia Chapéu, Terra Indígena Kaxuyana-Tunayana, pude escutar uma narrativa katxuyana a respeito de como eles conheceram as miçangas. Nessa narrativa, quem primeiro trouxe as miçangas para os Katxuyana foi um não-indígena que ficou conhecido entre eles por sua grande barba. Ele subia o rio numa canoa repleta de miçangas, em sacos enormes, de todas as cores, enfatizou essa mulher. Esse homem barbudo passou pelos Katxuyana, lhes deu algumas miçangas e seguiu sua viagem. Tempos depois, alguns Katxuyana foram convidados a ouvir a palavra de Deus em Kassawa, maior aldeia Hixkaryana, onde o missionário Desmond Derbshire, conhecido por Desmundo entre os índios, tinha intensa atuação (Lucas, 2014). Lá chegando, o pai da narradora da história disse que reconheceu o homem barbudo como sendo Desmundo, e que este lhe reconheceu do tempo em que havia passado pelas aldeias dos Katxuyana, dizendo assim: "Ei, eu sei quem é você: o Katxuyana que roubou minhas miçangas".

Essas múltiplas narrativas a respeito das miçangas entre os povos karib guianenses, o mostram que tanto seus usos como os tipos preferidos de contas estão intrinsecamente relacionados aos contextos em que circulam. Embora essa relação nem sempre apareça nos estudos de Bead Research, certamente são esses usos e tipos de miçangas que fazem desse objeto algo tão desejado entre povos ao redor do mundo.

\section{Circulações contemporâneas das miçangas}

As miçangas amarelas que estavam no pescoço de Cecília Awaeko, cujas palavras abrem a introdução da presente dissertação certamente não vieram com os Mekoro, tampouco apareceram dentro do pakara de algum japu. É bem possível que eu mesma tenha participado de sua aquisição, já integrando o circuito atual de circulação das miçangas, que implica na compra de miçangas diretamente em sua importadora, na região central de São Paulo. Sou

19 Em 2005, as mulheres Tiriyó e Katxuyana desenvolveram, junto ao Iepé, o projeto "Artesãs do Maramara", com o apoio do IPHAN/PNPI e da Petrobrás Cultural. Já em 2009, numa parceria da APITIKATXI com o Iepé, foi desenvolvido o projeto "Artesãs do Tumucumaque", com apoio do Museu do Índio. Em 2010, a Caixa Cultural apoiou o projeto "Tecendo a Arte, Tecendo a Vida: organização das mulheres tiriyó e kaxuyana em torno de sua arte com sementes e miçangas". Entre 2011 e 2012, foi desenvolvido o Projeto de Documentação de Culturas/ProDoCult, também parceria da APITIKATXI e do Iepé, e com o apoio do Museu do Índio/Funai; no âmbito desse projeto que desenvolvi minha iniciação científica a próposito das pinturas corporais tiriyó e katxuyana (Grupioni \& Oliveira 2012). 
participante ativa desse circuito, transportando tanto peças prontas das aldeias e cidades de referência (Macapá e Santarém) para a venda pela internet e em São Paulo, quanto levando para as artesãs e suas famílias mais miçangas, agulhas e linhas.

As mudanças que acontecem na circulação dos objetos ao longo dos tempos, conforme apresentadas acima, não atingem apenas os circuitos, mas afetam também os conhecimentos que circulam junto com os próprios objetos. Não há nenhuma novidade nessa afirmação, mas ainda assim os processos de circulação de miçangas (e conhecimentos delas indissociáveis) entre povos indígenas guianenses permite a observação dos efeitos que a intensificação das relações entre Estado e povos indígenas tem sobre seus modos de saber, em especial aqueles provocados pela etnificação - isto é, a necessidade de que esses povos posicionem-se enquanto etnias, tensionando a tradicional "abertura ao outro" que marca as dinâmicas de circulação de saberes e coisas (Lévi-Strauss, 1991).

Kasiripinã Wajãpi considera que sabe muito de kusiwa, arte gráfica wajãpi, por ter viajado muito, em contraste aos jovens de hoje em dia, cuja circulação vê-se restrita por fronteiras antes inexistentes, bem como pela escolarização e estreitamento de relações com as cidades próximas a suas terras indígenas. A afirmação de Kasiripinã Wajãpi ressoa com as dinâmicas que envolvem os repertórios de padrões gráficos de outros povos indígenas guianenses, como os Wayana e os Aparai (Van Velthem 1998, 2003; Van Velthem \& Linke 2010) e os Tiriyó e os Katxuyana (Grupioni, 2009), além do que já foi descrito para os próprios Wajãpi (Gallois et allii 2002; IPHAN 2008; Gallois 2012). É comum a todos esses povos que os padrões gráficos por eles utilizados em pinturas corporais, cerâmicas, entalhes em madeira, beijus, cestaria, enfim, em todo corpo decorado, não tenha sua autoria relacionada ao próprio povo que o executa. Em outras palavras, os desenhos feitos pelos Tiriyó, não são dos Tiriyó: são tirados de outros seres, como cobras, peixes, inimigos de guerras, pássaros, etc. E o mesmo pode ser dito para os demais povos guianenses, não se restringindo essa afirmação apenas aos povos de língua karib, como se observa o caso Wajãpi (língua tupi).

O principal efeito observado pela intensificação das relações como Estado Nacional entre essas populações, como dito, é a etnificação, que suplanta os diversos -yana/gentes da região, descritos como mais de 140 "sub-grupos" (Frikel 1958), por denominaçãos genéricas, como Tiriyó (que possivelmente não teria um yana anterior, mas que passa a existir com o englobamento dos Pïrouyana, Aipïpa, Aküyó, e outros), ou englobantes, como Katxuyana 
(que passa a designar a partir desse período não apenas a gente do rio Katxuru, mas também os Kahyana, Ewarhoyana, Yaskuriyana, dentre outros). Grupioni (2002, 2005, 2009) apresenta esses diferentes yana por meio do vocábulo itïpï, que, literalmente, pode ser traduzido como “continuação". A antropóloga apresenta que o termo é utilizado, por exemplo, para indicar que um rio é a continuidade de diversos igarapés, assim como crianças dão continuidade aos yana de seus ascendentes. Segundo a metáfora trazida por Grupioni (2002), os diferentes yana, entremeando-se pelas relações de casamento e de guerras, compõem um "jardim de veredas que se bifurcam", imagem esta que, fazendo referência à paisagem de cerrado encontrada na região, indica como a alteridade constitui a base do que a antropóloga considera o "sistema de mundo tarëno".

Tal lógica é bem diversa daquela pela qual funcionam as políticas públicas do Estado, em que o primeiro passo para se lidar com povos indígenas é a identificação étnica, no mais das vezes englobando sobre uma única (ou poucas) denominação, miríades de coletivos que se pensam de outras formas. A situação não é exclusiva entre os povos indígenas das Guianas, mas também em outros casos, como entre os Piro (Gow, 1991). Um exemplo está no caso das políticas de cultura, como a do registro de patrimônios culturais materiais e imateriais, em que cada repertório de padrões, apesar das detalhadas explicações a respeito das dinâmicas de captura do exterior para a composição desses repertórios, refere-se a um povo específico.

Assim, os padrões que, a partir do ponto de vista tradicional, pertencem a diversos outros seres, humanos e não-humanos, passam também, por direito, a serem considerados como de autoria de determinado grupo, provocando disputas entre os povos indígenas a respeito de quem seriam os verdadeiros donos de determinados padrões. Um elemento que aparece comumente nessas situações é o ciúme provocado pela vinculação da autoria desses desenhos, tal como quando os Tiriyó do rio Paru de Oeste tiveram contato com o Dossiê da Arte Kusiwa - Pintura Corporal e Arte Gráfica Wajãpi. Na situação, conforme relatou Denise Fajardo Grupioni (comunicação pessoal), os Tiriyó identificaram com sua própria nomenclatura cada um dos padrões gráficos wajãpi registrados, exigindo que eles também pudessem ter seu registro feito ${ }^{20}$.

Recentemente, em maio de 2019, pude ver situação semelhante repetindo-se com os Tiriyó do alto rio Paru d'Este, numa oficina de elaboração do registro da Arte Gráfica Wayana e Aparai junto ao IPHAN. Esse processo, solicitado pela APIWA à antropóloga Lúcia van

20 Ver também Gallois 2012 
Velthem, iniciou-se há cerca de 10 anos. Como a oficina aconteceu no contexto de uma das etapas da Formação de Jovens e Lideranças promovida pelo Iepé, estavam reunidos não apenas jovens e lideranças Wayana e Aparai que habitam o rio Paru d'Este, mas também Tiriyó, Akuriyó e demais yana que habitam a porção mais ao alto deste rio. Este segundo grupo demonstrou-se contrafeito em não integrar o dossiê em processo de organização, afinal reconheciam muitos dos padrões ali inventariados como também utilizados por eles em na ornamentação de seus corpos e objetos ${ }^{21}$.

Interessante notar que apesar desse recente movimento de etnificação provocar essas situações de controvérsia em torno da origem dos padrões gráficos, no que concerne às miçangas, em específico, tal como destacou Lúcia van Velthem em diversos momentos na oficina acima referida, o que temos são possibilidades tão inúmeras que se torna praticamente impossível inventariá-las. Além disso, a fabricação de colares, pulseiras e demais adornos têm como base largamente apreciada pelas mulheres artesãs exatamente a cópia, ou antes, a imitação de outros objetos.

Imitação essa que remete aos processos tradicionais de captura dos padrões gráficos de outros seres: assim como os homens Wayana e Aparai copiaram da cobra grande sobrenatural Tuluperê seus padrões gráficos para colocá-los em suas cestarias, as mulheres copiam não apenas das cestarias masculinas esses desenhos, como de diversos outros corpos, tais como peças de miçangas trazidas das cidades, ou nelas encontradas nas situações em que viajam para lá, principalmente para atendimentos de saúde ou resolução de situações com documentos. Ou, ainda e cada vez mais frequência, peças que encontram na internet, conforme apresentaremos na próxima seção, dedicada aos circuitos atuais de circulação das miçangas.

\section{Miçangas em redes sem fio}

Se as miçangas potencializaram padrões de estética já encontrados entre os povos ameríndios, nos dias de hoje, vemos a circulação desses objetos - portanto dos conhecimentos ligados à sua produção - também potencializada pelas atuais tecnologias, marcadamente o

21 O ciúmes experimentado pelos Tiriyó em relação à patrimonialização dos padrões gráficos pode ser visto como consequência da etnificação provocada pela interação com o estado nacional, pois faz com que cada povo indígena se pense como uma unidade, e não como uma rede de relações com os outros. Isso faz com que, no caso, a origem dos padrões gráficos seja vista sob a ótica da exclusividade, e não do compartilhamento em rede de saberes. 
acesso à internet e o uso dos smartphones. Tal tema tem sido recentemente trabalhado na antropologia, como Klein (2013), embora não haja bibliografia pertinente ao caso dos povos indígenas guianenses. O que apresento aqui, longe de ser uma reflexão aprofundada, é apenas um esboço que aponta para possíveis desdobramentos futuros.

As Terras Indígenas Parque do Tumucumaque e Rio Paru d'Este, como já mencionado, são locais de difícil acesso: apenas via aérea, sendo que na maioria absoluta das pistas de pouso existentes, apenas aviões monomotores conseguem pousar ${ }^{22}$. A comunicação entre as aldeias e quem está fora das terras indígenas acontece por radiofonia, exceto na região da Missão Tiriyó, onde há a possibilidade de utilizar a conexão de internet wireless do Exército Brasileiro, que, após muita negociação com os caciques locais, disponibilizou uma sala para uso exclusivo dos índios ${ }^{23}$. Apesar da instabilidade da conexão, a sala de acesso nunca está vazia. O uso principal da internet é para a comunicação via redes sociais - Whatsapp e Facebook - com parentes que estejam na cidade ou do outro lado da fronteira, no Suriname. O compartilhamento de imagens e de vídeos é frequente e muito variado, bem como a utilização de grupos para o compartilhamento dessas mídias, sobre os mais diversos assuntos.

Como dito, o acesso à internet dentro das terras indígenas em questão é difícil e concentrado apenas numa sala localizada nos arredores da Missão Tiriyó, implicando num número bem reduzido de pessoas que conseguem de fato fazer uso dessa ferramenta de comunicação. Nas demais aldeias da região, o compartilhamento de informação dos smartphones acontece sobretudo via um aplicativo chamado ShareIt, que apenas encontrei em funcionamento entre os povos indígenas dessa região. Esse aplicativo permite o compartilhamento de arquivos com velocidade muito superior ao bluetooth, e até mesmo o envio de mensagens em formato de chat. Apesar de ter sido curiosa a experiência de conhecer um aplicativo excelente para o compartilhamento de arquivos numa região em que não há nenhum sinal de celular, é perfeitamente consistente que povos que prezam tanto pela circulação de informações tenham bom domínio também dessas novas tecnologias.

22 Assinala-se também que, com exceção da pista de pouso da Missão Tiriyó, localizada junto a uma base da Força Aérea Brasileira, nenhuma das outras é homologada pela ANAC, dificultando - e, por vezes, inviabilizando - o acesso aos serviços de educação e saúde públicos.

23 Após o depósito da presente dissertação, houve a instalação de uma antena para acesso a internet via satélite, na escola da aldeia Missão Tiriyó. Contudo, o funcionamento do equipamento depende de energia elétrica cuja disponibilidade é rara, dependendo de grandes quantidade de combustível para o acionamento dos geradores instalados pela missão franciscana em décadas anteriores (os mesmos também são ligados à uma pequena central hidrelétrica construiída pelos missionários quando de sua instalação no local, mas que tem sofrido com secas constantes em sua represa). 
No que tange à circulação de miçangas, o movimento atual em relação a modelos e desenhos pode ser descrito como se iniciando nas cidades, onde o acesso à internet é mais regular. Principalmente as mulheres Wayana e Aparai, que estão há mais tempo em Macapá, acessam materiais como vídeos de tutoriais produzidos no México e na Colômbia, ou simplesmente imagens vindas de buscas na ferramenta de pesquisa do Google, para o aprendizado de desenhos e técnicas. A partir da produção desses artesanatos (como elas mesmas se referem às peças por elas produzidas e destinadas à venda), a circulação chega na aldeia de dois modos: um deles, a partir dos próprios objetos, quando alguém se desloca da cidade para a aldeia, transportando esses materiais; o outro modo é pelo compartilhamento das imagens pelos próprios celulares, geralmente pelo aplicativo acima mencionado.

Mesmo durante as visitas que tenho realizado nas aldeias, ao longo dos últimos meses, em que costumo trazer comigo o catálogo da exposição No Caminho das Miçangas (Lagrou 2016), o papel dos smartphones é marcante: as mulheres, em especial jovens, logo aparecem com seus aparelhos (às vezes compartilhados com seus maridos), escolhendo peças das quais tiram fotos para que possam copiar os modelos do mesmo, que prontamente reproduzem. Também sou constantemente requisitada a enviar fotos de pulseiras e colares de miçangas, orçamentos de compras de miçangas, questionamentos a respeito das peças que me foram enviadas para a venda. Por acompanharem minhas atividades nas aldeias e também o desenvolvimento da presente pesquisa de mestrado, essas mulheres indígenas se mostram sempre compreensivas com minhas demoras, e incentivam bastante essas outras atividades.

No próximo capítulo, o principal enfoque será a descrição das técnicas utilizadas, principalmente pelas mulheres indígenas Tiriyó, mas também com alguns dados relativos às mulheres de outros povos karib e tupi da região. Com isso, pretendo destacar os limites que a técnica imprime à cópia, e como isso resvala também nas preferências adotadas pelos diferentes povos, participando inclusive na composição de uma identidade visual comum aos índios que participam ativamente de situações da esfera pública da luta indígena, não apenas no Brasil, mas num âmbito até mesmo de América Latina, como se pode ver pelo uso amplamente difundido dos colares ditos de "onça".

O contraste que intentamos aqui descrever se dá nessa controvérsia das lutas identitárias: ao mesmo tempo em que é fundamental que se elejam elementos que permitam identificação e resistência frente aos ataques que cada vez mais os povos indígenas vêm sofrendo em larga escala pelo Estado Nacional, as próprias políticas culturais por ele 
promovidas implicam nessa etnificação que tenta engessar origens e usos mais adequados para os padrões gráficos. No interstício entre copiar dos outros e intentar restringir que se copie do seu que podemos apreciar tanto a formação de identidades visuais pan-guianenses quanto o aparecimento de estilos regionais, mas, principalmente o modo como esses povos têm lidado com os efeitos que nossa sociedade atual tem provocado sobre as concepções nativas relacionadas à circulação de saberes e à fabricação de corpos, dentre outros pontos.

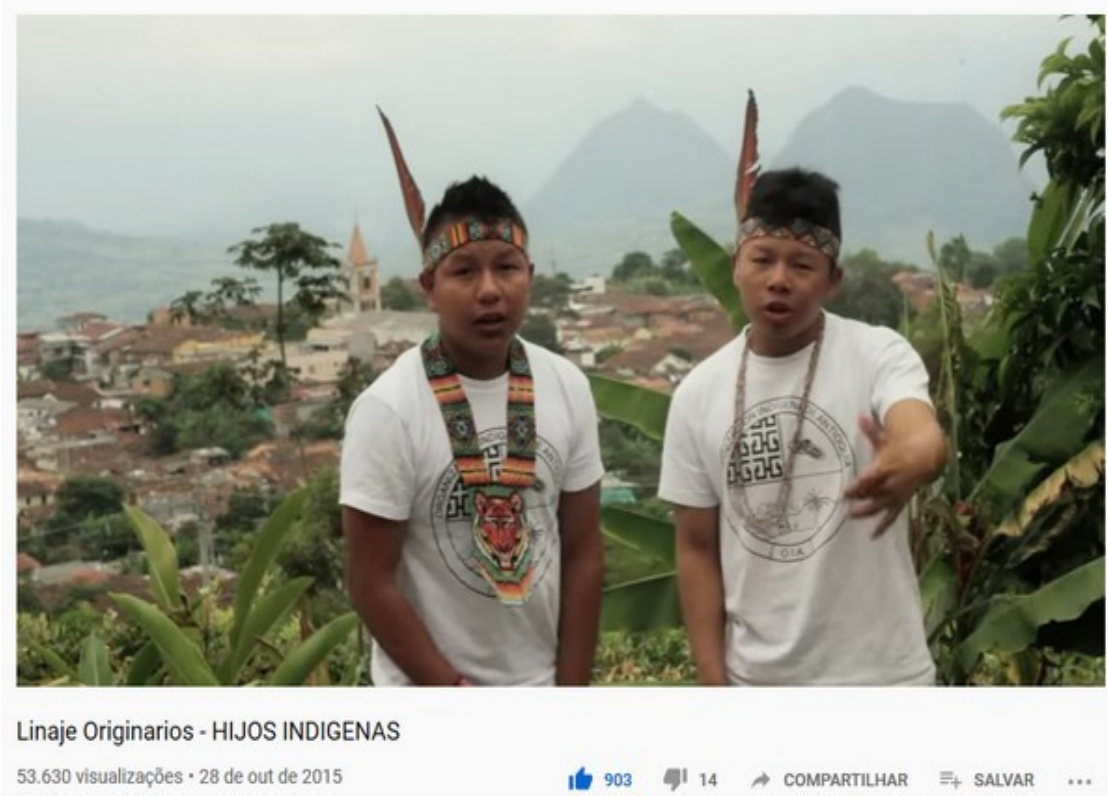

Figura 13: Frame do videoclipe dos rappers Embera Linaje Originarios (Colombia). Disponível em https://www.youtube.com/watch?v=FvYjOXAuTVE. [Acesso 30 de setembro de 2019]

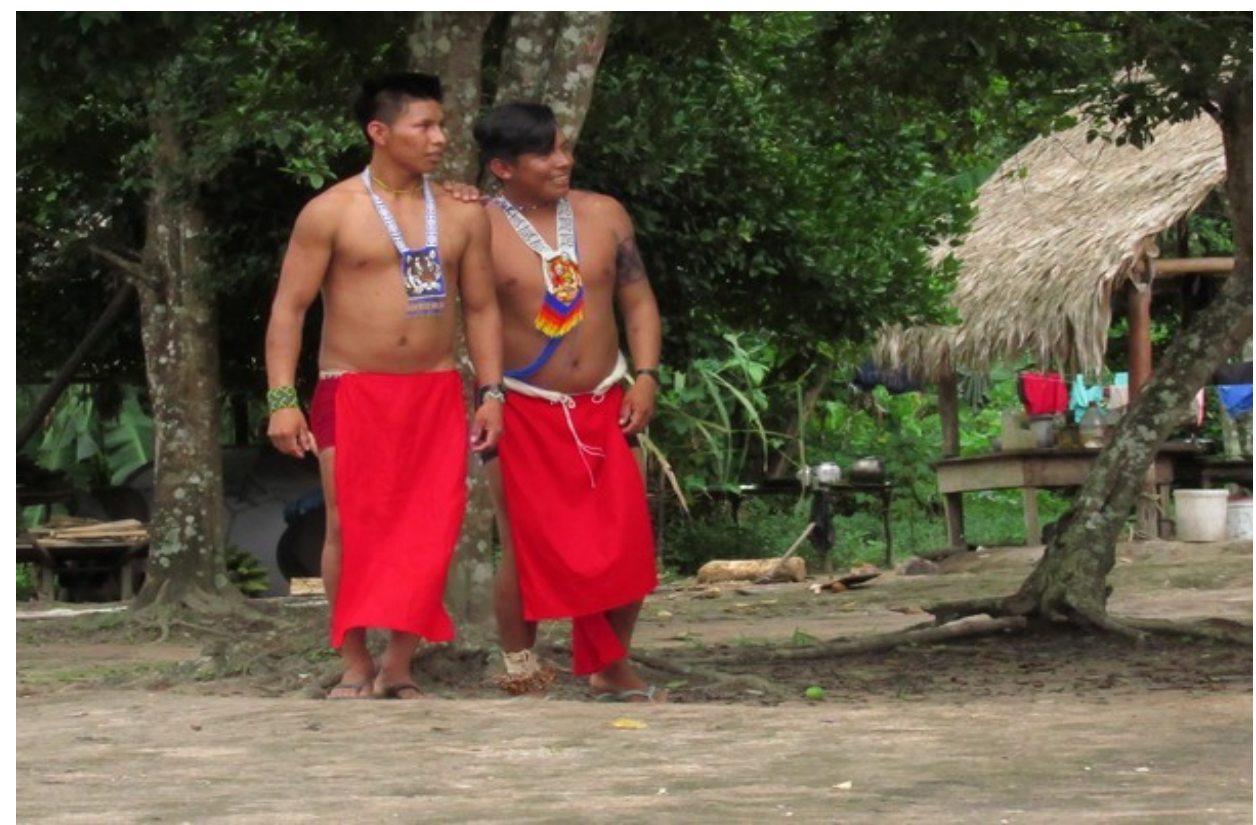

Figura 14: Jovens Wayana preparam-se para uma festa. Aldeia Xuixuimene, TI Rio Paru d'Este, abril de 2019. 
Capítulo 2: Samura Rïtohton - Assim que tecemos miçangas 
Lurdes Kaxuyana senta-se numa rede e me fala dos objetos incompletos de miçangas que estão em uma tigela em seu colo, tirada de um balde plástico com tampa, que também contém outros apetrechos para o trabalho com miçangas, além de materiais de crochê. "Essas eram do meu sogro", diz, ao me mostrar fios de miçangas, nas cores branca, azul e laranja. "Esse era do meu marido. Agora vou copiar para os meus filhos", explica, rindo, a respeito de um pedaço de panti, cinto masculino, já quase inteiramente desfeito.

Observar o pote de miçangas de uma mulher pode nos sugerir muitas coisas. De modo geral, atualmente, são recipientes de plástico, com tampa, que ficam guardados em algum lugar de difícil acesso para que crianças não derrubem. Dentro desses potes, encontramos miçangas de várias cores, misturadas, sobretudo no tamanho 9/0, além de linhas e agulhas, bem como peças que não estão concluídas. Uma moça jovem dificilmente terá muitas miçangas: ela deve contar com a generosidade de mulheres mais próximas de sua família para que possa desenvolver suas habilidades de tecelã.

É verdade que a quantidade de miçangas de uma mulher indica a intensidade de suas relações com parceiros de troca, principalmente pessoas externas às aldeias; relações estabelecidas tanto por parte de seu marido, quanto, hoje em dia, por sua própria parte. Assim, há alguns anos, quando o fluxo de miçangas dependia muito das relações de troca com os mekoro, eram os homens tarëno $^{24}$ que necessariamente conseguiam miçangas para suas esposas. Hoje em dia, cada vez mais as próprias mulheres têm estabelecido relações de troca com variados parceiros, tal como pessoas que trabalham na saúde e na educação indígena, ou mesmo em organizações não-governamentais, como é meu caso.

O sogro de Lurdes Kaxuyana, Matias Ape Tiriyó, faleceu no ano passado (2018). Ele era muito respeitado, sendo considerado um dos últimos velhos "que sabia tudo", inclusive dos conhecimentos aprofundados de xamanismo, "mas não para matar", segundo seus familiares. $\mathrm{O}$ fato de suas miçangas estarem guardadas é significativo das transformações nos modos de tratamento dos bens dos mortos, nesta aldeia e em toda a região ${ }^{25}$. Tradicionalmente, os adornos costumavam ser enterrados junto com outros bens da pessoa falecida. Segundo Lurdes Kaxuyana, essas miçangas emaranhadas, que lhe vieram de seu sogro, constituíam iyafan (bandoleiras); destas, as azuis e as laranjas são dos tempos das trocas com os mekoro, mas as brancas foram trazidas por Denise Fajardo (Grupioni), antropóloga que atua na região desde a década de 1990. As cores laranja e azul são as mais

24 Ver Introdução, pág. 20.

25 Para as transformações em curso entre os Wayana e Aparai, ver Barbosa 2007. 
utilizadas para fazer esse tipo de adorno, compondo cores contrastantes, como se nota nos arranjos de cores em toda a região (Van Velthem 2003). Algumas pessoas também dizem que as cores de miçangas que primeiro chegavam na região pelos mekoro eram exatamente essas duas.

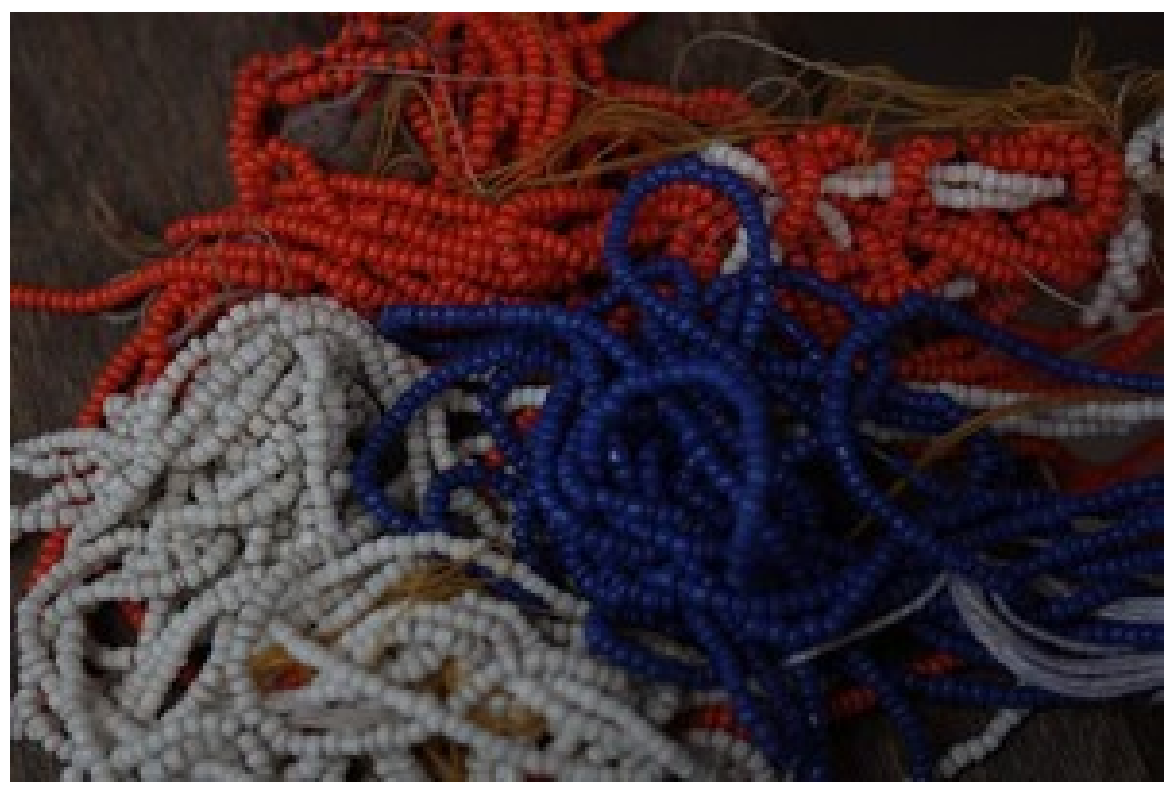

Figura 15: Bandoleiras (iyafan) de Matias Ape Tiriyó, falecido em 2018, guardadas por sua nora Lurdes Kaxuyana.

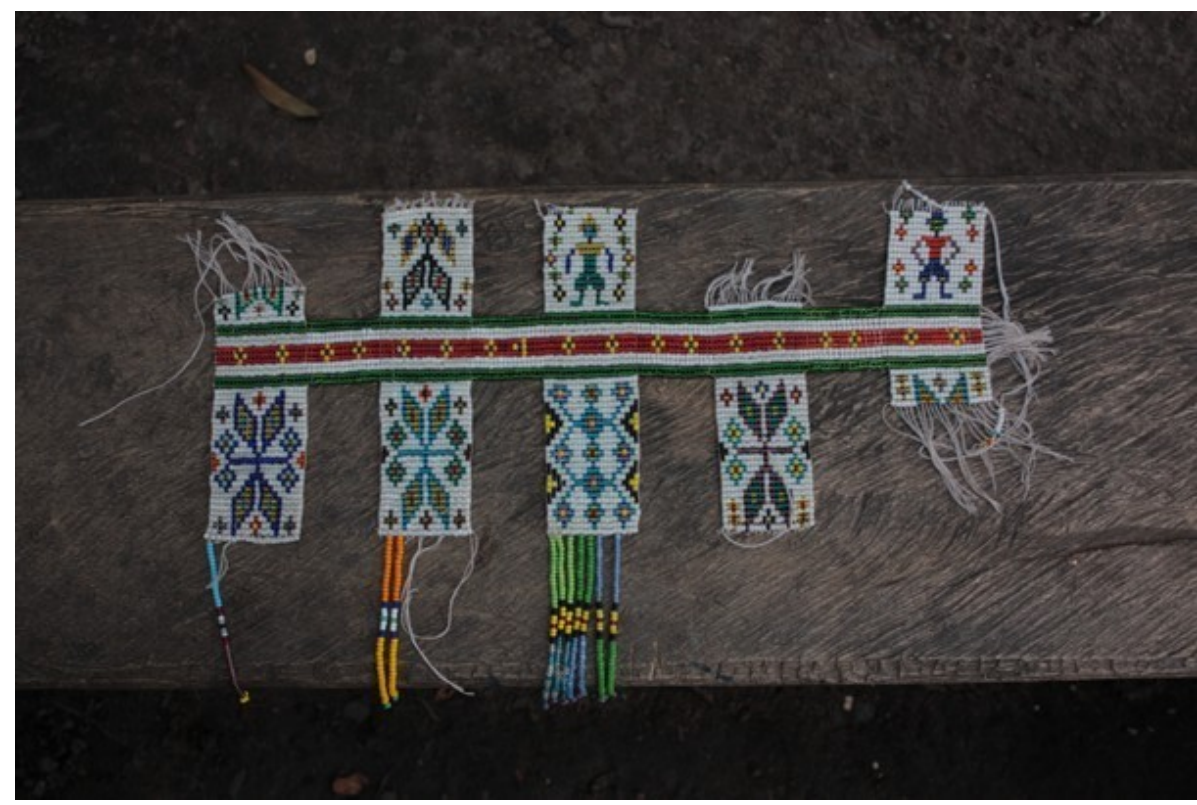

Figura 16: Pedaço de panti, cinto masculino, que pertencera ao marido de Lurdes, Tito Meri Tiriyó, donde ela agora copia padrões gráficos para os cintos de seus filhos. 
O pedaço de panti no pote de Lurdes pertencia ao cinto que ela havia feito para seu marido, Tito Meri Tiriyó, anos atrás. Agora, ela estava se inspirando nos desenhos para não só consertar o panti de Tito Meri como também para fazer novos cintos para seus filhos, Aventino Nakai Kaxuyana Tiriyó (recém-eleito presidente da Associação dos Povos Indígenas Tiriyó Katxuyana e Txikiyana/APITIKATXI) e Otávio Mitipo Kaxuyana Tiriyó, professor e diretor auxiliar da escola da aldeia.

Iyafan e panti são dois dos elementos indispensáveis na vestimenta hoje definida como "roupa tradicional" dos homens pelos Tarëno. Agregam-se a essas peças outros elementos, feitos de algodão, plumária e miçangas, acrescentando-se ainda pinturas corporais. Para as mulheres, ao invés do cinto panti, há a saia frontal ou tanga, denominada em língua tiriyó de keweyu - objeto de miçangas de maior destaque por elas produzido. A "roupa tradicional" é usada principalmente por ocasião de reuniões e assembleias, mas também em grandes festas, como o Natal. Essas ocasiões serão exploradas em maior detalhe ao longo deste capítulo e no subsequente também. Por hora, o que nos interessa é efetuar uma descrição comparativa do que diferentes povos guianenses indicam como suas "roupas tradicionais", termo utilizado por eles próprios em língua portuguesa para se referir a esse conjunto específico de indumentária.

\section{Pakaratao, patupisi marë - dentro dos recipientes}

$\mathrm{O}$ armazenamento das miçangas, tal como relatado no mito que abre o capítulo anterior, é feito cuidadosamente em recipientes fechados, que são guardados de modo seguro, protegidos de outras pessoas (principalmente crianças) e animais, como macacos ou jacamins. Atualmente, é comum que o armazenamento de miçangas e seus apetrechos (agulhas, fios, tesouras etc.) seja feito em potes plásticos com tampa, chamados patupisi. Antes, e até recentemente, eram guardadas em cestos retangulares chamados pakara, como descrito na narrativa mítica do Japu citada no capítulo anterior. Nesses cestos, as miçangas encontravamse dispostas em fieiras ou bandoleiras, ou enroladas em retalhos de tecido. Nos dias de hoje, os recipientes acima mencionados podem ser guardados dentro de baldes plásticos com tampas, ou malas. As miçangas não são separadas por cores, mas sim dispostas juntas, misturadas. As peças prontas costumam ser guardadas não muito distantes daquelas ainda em preparação, em sacos ou mochilas. 
Xipatai Apalai tem como pakara uma mala de metal, que já foi muito comum na região, mas praticamente não é mais encontrada hoje em dia. Dentro dela, guarda não apenas seus apetrechos de tecelagem com miçangas, mas, principalmente, novelos e fusos de algodão, com linhas de variadas espessuras. Assim como Lurdes Kaxuyana, Xipatai Apalai consegue dizer a proveniência das variadas miçangas que compõem as tangas, chamadas weju em língua aparai, que já estão prontas: algumas vieram da Guiana Francesa, outras de Macapá e de São Paulo. Boa parte de suas miçangas foram presentes de variados antropólogos que passaram pela sua casa, como Daniel Schoepf, Beatriz Perrone-Moisés, Gabriel Coutinho Barbosa.

Em relação ao descarte, observa-se uma mudança em relação ao comportamento dos antigos, já notada por Barbosa (2002) para os Wayana e os Aparai: se antes as adornos de uma pessoa eram colocadas na sepultura, com os demais pertences do falecido, com o tempo, certos bens passaram a ser considerados como herança. Em geral, são bens duráveis, industrializados ou de difícil obtenção, como é o caso de miçangas ou televisões. Brightman (2007) também inclui outros itens, como cocares, ao mencionar as práticas dos Trio de Suriname.

Adiante, serão apresentadas diferentes técnicas através das quais são produzidos objetos de miçangas. Embora esses dados se refiram especificamente ao que pude conversar com mulheres tiriyó, a semelhança na produção de artefatos de miçangas entre os diversos povos karib guianenses faz pensar que essa descrição das técnicas se aplica aos demais povos da região, com as devidas diferenças linguísticas. Também ressalta a consistência com as técnicas descritas por Frikel $(1973)^{26}$. Antes de adentrarmos nas técnicas em si, contudo, algumas ponderações a respeito das cores e dos tamanhos das miçangas, bem como de materiais utilizados na execução dessas técnicas, isto é, agulhas, fios e outros pendentes. Os teares utilizados em algumas dessas técnicas serão descritos posteriormente.

26 Durante a banca de defesa, houve a sugestão por parte da antropóloga Lúcia Hussak van Velthem de que as descrições apresentadas neste capítulo fossem enquadradas pelos apontamentos de Berta Ribeiro (1988). Optei por manter a descrição já realizada, visto o escopo desta pesquisa ser mais as relações que se efetuam com as miçangas e por meio delas, do que uma reflexão de cunho museológico das mesmas. De toda forma, a referência ao trabalho exaustivo de Berta Ribeiro não deixa de ser mencionada, destacando-se as seções "Cordões e Tecidos" (pp. 77-110) e "Adornos de Materiais Ecléticos, Indumentária e Tocador" (pp. 147191), inclusive com a descrição de diversas peças guianenses. 


\section{Selecionando cores}

Não há nenhum estudo aprofundado sobre como os povos indígenas das Guianas percebem e classificam as cores. Em relação aos Wayana, Schoepf (1976) menciona a refinada percepção dos tons de azul para os Wayana, enquanto Lúcia Van Velthem (2003) apresenta uma análise a respeito do local do branco, do preto e do vermelho - sendo as observações da antropóloga os relatos mais aprofundados a respeito do local das cores para esses povos. A dificuldade de se trabalhar esse tema não nos impede de destacá-lo como de profundo interesse, visto esse assunto sempre ser mobilizado quando se trata de miçangas.

São dois os sentidos em que podemos trabalhá-lo: preferências pelas cores, individualmente falando, bem como suas combinações. Não é de se espantar que as cores preferidas sejam exatamente aquelas já destacadas por Van Velthem (sup.cit): branco, preto e vermelho, incluindo ainda o amarelo. Ocasionalmente, substitui-se o preto pela cor chamada de "azulão", azul de tom extremamente escuro, ou ainda o vermelho por tons vivos de laranja. Evidente que outras cores também entram nos pedidos, mas essas dificilmente estão ausentes. As mulheres mais velhas preferem as miçangas foscas, enquanto as mais novas apreciam bastante as miçangas brilhantes.

Não há nenhuma cor especialmente depreciada pelas mulheres indígenas da região. Como dito, para a elaboração dos adornos que compõem a roupa tradicional, podemos notar preferências pelas cores mencionadas: azul e laranja para as bandoleiras (ou ainda outras variações de combinações, como verde e vermelho, ou preto e branco, ou azul e amarelo, destacando-se o contraste marcante entre as cores), miçangas foscas em cores contrastivas para os keweyu/weju, tais como, para as Tiriyó, preto/branco, azul escuro/branco, vermelho/branco, laranja/preto, amarelo/preto, ou, para as Wayana e Aparai, azul, branco e laranja.

Aliás, é o contraste entre as cores uma das principais marcas estéticas da região. As bandoleiras e as tangas são os objetos que mais destacam esse apreço pelo contraste, conforme descrito acima. Mas também em todas as outras peças produzidas podemos reparar que há, praticamente, uma ausência completa da utilização dégradé, que começa a aparecer em algumas peças para a venda feitas por mulheres que moram na cidade. Por um lado, essa ausência pode ser explicada pela dificuldade material em dispor de todas as tonalidades necessárias para a execução dessa escolha cromática; por outro, o contraste é a marca também 
das pinturas corporais, executadas com jenipapo (escuro) seja sobre a pele recoberta de urucum (vermelho) ou diretamente sobre a pele.

Observando as peças das coleções etnográficas do Museu Paraense Emílio Goeldi, coletadas principalmente na década de 1960, percebe-se que uma das recorrências com as pessoas produzidas atualmente (50 depois, portanto), está no contraste das cores nas peças. Isso pode ser visto, inclusive, como uma marca do modo karib guianense de se trabalhar com cores. É o contraste que sustenta os padrões trançados pelos homens com arumã, e que torna bonitas as peles das onças-pintadas e das sucuris, por permitir que melhor se apreciem os desenhos nelas encontrados, como Van Velthem (2003) já sinalizava para os Wayana. As pinturas corporais de jenipapo também são tão mais apreciadas quanto maior o contraste com a pele em que estão feitas. No caso da tecelagem com miçangas, vemos essa mesma apreciação estética, mas numa profusão de cores muito maior, em especial nos dias de hoje, pela própria variabilidade que o material permite.

Assim, o que algumas pessoas podem enxergar como combinações insólitas de cores nas peças atualmente tecidas, pode ser visto muito mais como um exercício de criatividade das mulheres em explorar esse contraste que tanto apreciam em diversas outras expressões, exacerbado pelas diferentes cores em que as miçangas podem ser encontradas hoje em dia. Contudo, algumas artesãs e lideranças com mais vivência em cidades sustentam a importância de capacitar as artesãs das aldeias na combinação de cores para a produção de peças para a venda.

Outra característica comum entre as peças produzidas nas décadas de 1960 e 1970 e aquelas mais contemporâneas é uma sutil mudança de cor no meio da trama, que pode consistir desde toda uma faixa de miçangas em outro tom, ou alternando entre fosca e translúcida, até uma única miçanga em outra cor. Muitos podem considerar que essas pequenas mudanças acontecem por distração da artesã ou por falta das cores necessárias, mas a recorrência deste tipo de detalhe nos leva à hipótese de que pode se tratar de algo mais interessante, que poderia remeter àquilo que Gabriel Tarde chamava de diferença infinitesimal (2007). No caso dos padrões da arte visual Tiriyó e Katxuyana, poderia indicar a sempre presente possibilidade de mudança: um padrão tem a potência de se tornar outro, a variabilidade estando no cerne deste modo de ser ameríndio. 


\section{Formatos e tamanhos das contas}

Os diferentes tamanhos de miçangas também apresentam refinadas apreciações pelos povos indígenas tanto da América do Norte quanto da América do Sul. Gray (2017) relata, tal Dubin (1987), como as chamadas pony beads trazidas pelos franceses vão ganhando maior apreço por seu tamanho reduzido entre povos da região das Planícies. Entre os povos da América do Sul, as miçangas número $15 / 0$ vão sendo pouco a pouco conhecidas pelos diferentes povos indígenas, e fazendo muito sucesso.

O tamanho 9/0 é o mais comumente utilizado pelos povos indígenas das terras baixas da América do Sul. Segundo relatos das mulheres tiriyó e katxuyana, os Mekoro já traziam miçangas desse tamanho, bem como os missionários evangélicos e católicos. Esse tamanho é chamado, em língua tiriyó, tanto de samuraran ("miçanga verdadeiro", como dizem língua portuguesa) quanto por mokoko enu (“olho de caranguejo"). O tamanho 6/0 também é utilizado e conhecido há muito tempo: de modo geral, ele aparece nas franjas dos keweyu (saias frontais), mas também é apreciado para compor as bandoleiras. Conheci uma única mulher aparai que preferia utilizá-lo para a confecção de weyu (denominação aparai para a saia frontal), segundo ela por já ter dificuldade de enxergar as miçangas menores. Nas línguas wayana e aparai, esse tipo de miçanga recebe o nome kasurutëpu ou kahurutopu; já em língua tiriyó, essa miçanga tamanho 6/0 recebe o nome de kuritaraimë. Escutei duas versões acerca da etimologia dessa palavra: em uma, faz referência a um fruto encontrado no campo, alimento do jabuti (kuriya); em outra, remete a kuri, pedras que materializam espíritos, uma das posses restritas aos pajés.

Atualmente, é muito raro encontrar alguém que já tenha visto kuri de algum pajé. Foime contado que seriam pedras bem redondas, mas sem o furo no meio que caracteriza miçangas e contas. Uma mulher indígena chegou a traduzir para mim kuri como "espírito". Outra narrou-me que certo pajé (Yonare) possuía vários kuri, e que ela podia vê-los em uma panela. Haveria kuri tanto para fazer o bem, como curar alguém, quanto para fazer o mal, como matar alguém, ou até mesmo para a proteção das pessoas, avisando, por exemplo, se determinado estrangeiro que estivesse chegando nas aldeias seria "amigo, trazendo coisas para trocar, ou inimigo, vindo para matar mesmo". Não seria possível distinguir esses diferentes tipos de kuri apenas olhando-os. Daí seu perigo, quando utilizados por pessoas não-detentoras 
dos conhecimentos de pajé. Frikel descreve kuri como pedras enterradas na roça para garantir a fertilidade da mesma (1973:79).

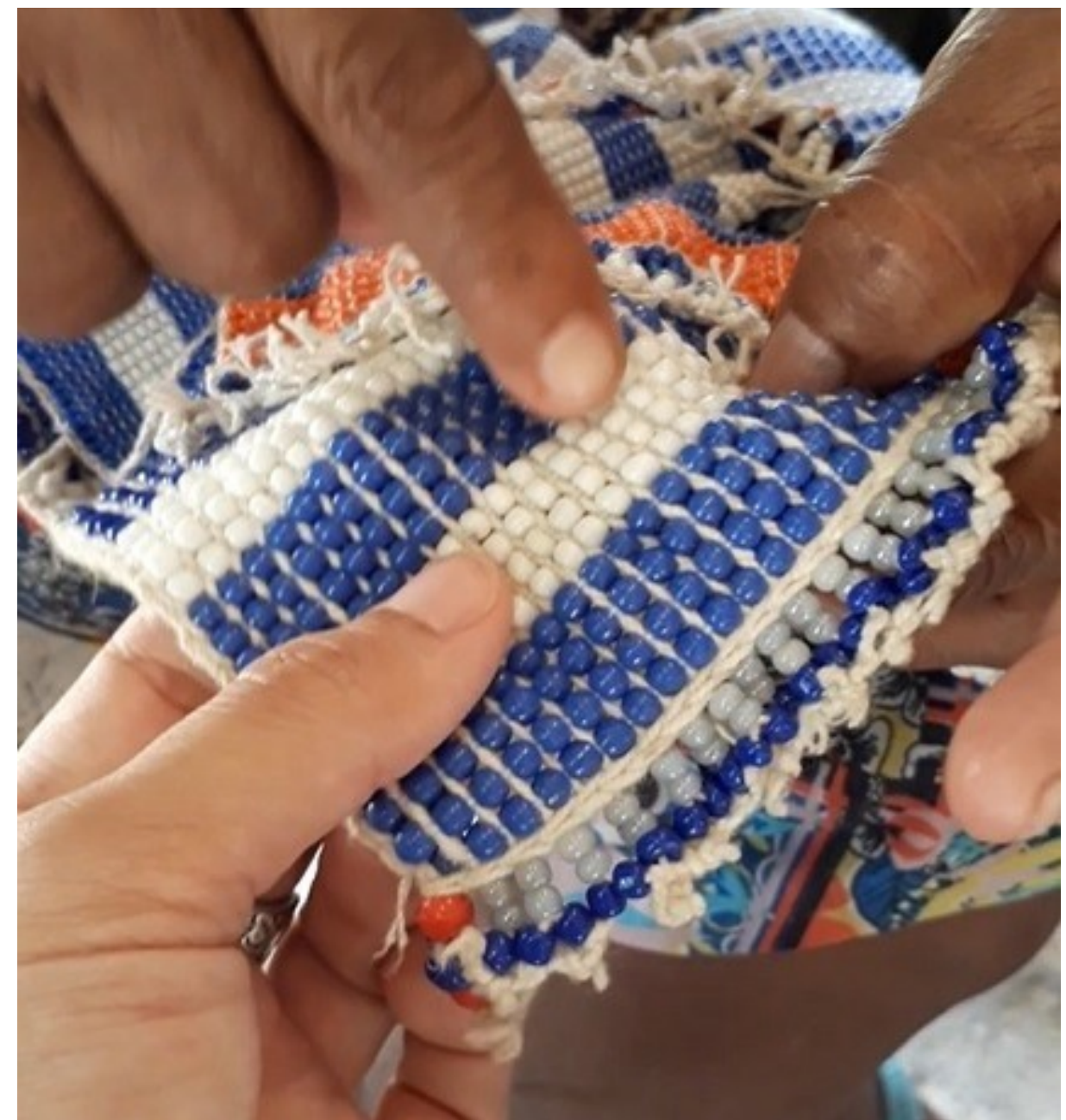

Figura 17: Xipatai Apalai indica a proveniência das diferentes miçangas (as brancas vieram da Guiana Francesa) que utilizou na feitura de seus weju; Xipatai prefere utilizar miçangas tamanho 6/0, chamadas kahuru tepu (wayana) ou kasuru topu (aparai).

O tamanho 12/0 é, atualmente, o mais cobiçado pelas mulheres da região. Já passei por situações em que as desapontei ao trazer as miçangas 9/0. Entre as mulheres tiriyó, pode-se chamar esse tamanho de mükaka enu, olho de formiga saúva, mas é comum ser referido como samura akï pïsi ou samura piyam pïsi, isto é, miçanga pequenina. A utilização dessas miçangas já implica em outros tamanhos de agulha e de linha, mas não tão difíceis de serem encontrados quanto os materiais necessários para trabalhar com as menores miçangas atualmente disponíveis no mercado, o tamanho 15/0. 
Poucas mulheres do lado oeste do Tumucumaque já conhecem esse tamanho de miçangas. Posso arriscar a dizer que muitas delas só o viram mesmo pelo samura ikuhtu que carrego comigo, conforme por elas batizado o mostruário de cores e tamanhos de miçangas disponibilizados pela importadora das mesmas (Fig. 3, na página 38). Sempre acham esse tamanho o mais lindo possível, mas se espantam com o preço a que pode chegar. Costumo fazer a equivalência das quantidades de miçangas que podem ser compradas com o mesmo valor em reais, e elas logo abandonam a ideia de ter a miçanga 15/0. As mulheres do lado leste, porém, tem cada vez mais encomendado esse tamanho de miçangas, em especial aquelas que passam longas temporadas na cidade de Macapá. Para elas, a venda de artesanato constitui não são uma atividade apreciada, como também significativa fonte de renda. As mulheres wajãpi, por outro lado, cada vez mais encomendam miçangas $15 / 0$, mas não para a venda, e sim para uso próprio.

É alegado que os tamanhos menores são preferidos por serem mais bonitos, isto é, por permitirem que se "veja melhor" o desenho, pois as miçangas ficam mais próximas umas das outras. A dificuldade técnica também é reconhecida, citada mesmo por artesãs habilidosas como um motivo para não utilizar as miçangas 15/0. Uma mulher muito habilidosa, Rosineide Saripun Kaxuyana Tiriyó, chegou a me dizer que nunca mais gostaria de trabalhar com miçangas 15/0 porque ficou com dores nos dedos e nos olhos, e o trabalho demorou muito para ser finalizado. Outra dificuldade comentada é o tamanho de agulha que necessita ser utilizado: apenas encontrada na mesma loja da importadora das miçangas, o pacote com 25 agulhas não sai por menos de 90 reais; para as mulheres Katxuyana e Waiwai, a dificuldade do trabalho com essas pequenas miçangas consiste exatamente em conseguir executá-lo sem a utilização de nenhuma agulha.

\section{Agulhas}

Em língua tiriyó, a palavra para agulha é akusa. Seguindo as descrições dos primeiros cronistas e dos exploradores que lhe seguiram, podemos acreditar que as agulhas circulam pela região há tanto tempo quanto as próprias miçangas, pois costumam fazer parte das listas enumeradas nestes relatos, assim como outros materiais tais botões, guizos e tecidos. É verdade que esses relatos não nos informam se as agulhas já eram utilizadas para a tecelagem com as miçangas, mas esse ponto não é relevante em nossa descrição. 
Atualmente, as artesãs usam preferencialmente três tipos de agulhas, que devem ser resistentes e finos, não enferrujando com facilidade. Inclusive, como descreve Van Velthem (2010), a qualidade das agulhas também é avaliada em termos de "originais" ou "importadas": as agulhas nacionais são preferidas às chinesas. Desses três tipos, dois tipos são os mais comumente solicitados, a diferença entre eles sendo principalmente o comprimento. $\mathrm{O}$ primeiro tipo, muito utilizado na tecelagem de pulseiras, colares e tangas, tem cerca de $10 \mathrm{~cm}$, mas não é facilmente encontrado nem em Macapá nem em São Paulo. O segundo tipo compreende as agulhas de costura à mão tamanho 12, apreciadas para todo tipo de trabalho, e mais comuns nos diferentes centros comerciais. Por fim, o terceiro tipo é a agulha inglesa necessária para o trabalho com miçanga 15/0, que, como mencionado, ainda são utilizadas por poucas mulheres.

\section{Fios}

São diversos os tipos de fios utilizados nas tecelagens com miçangas. Nas peças localizadas no Museu Paraense Emilio Goeldi, isso pode ser vislumbrado, seja em relação à matéria-prima, seja em relação a cores, calibres, estado de conservação. As linhas de origem vegetal são sobretudo feitas de algodão, mas em algumas peças é possível perceber o uso de fibra de vegetal, provavelmente curauá. A maior parte das peças é de fato fabricada com algodão tecido à mão, sem tingimento, mas é possível perceber que algumas dessas linhas foram tingidas, tanto de urucum quanto de jenipapo, seja antes da fabricação da peça, seja pelo uso da mesma em contato com a pele ungida por essas tinturas.

As linhas de origem industrial apresentam-se em variadas cores, tanto claras quanto escuras (difícil precisar se brancas ou bejes, no caso das claras, ou azul ou pretas, no caso das escuras), e mesmo nas cores vermelho, marrom ou verde. Destaca-se que o uso de linhas industrialmente produzidas é mais pronunciado entre as peças de origem katxuyana, provavelmente pelo contato intensivo anterior desse povo com frentes não-indígenas, como balateiros e mateiros, ou mesmo com os quilombolas residentes na região do rio Trombetas.

Embora variando em seu calibre, de modo geral, as linhas eram tecidas de modo bem fino, de modo a permitir a trama com as pequenas miçangas tamanho 9/0. Linhas mais grossas aparecem sobretudo nas franjas, recorrentes tanto nas tangas (keweyu (tiriyó)/monenoho 
(katxuyana)/ weju (wayana e aparai)) quanto em brincos, pingentes, jarreteira e enfeite para os cabelos.

O principal indicador de que as peças eram ou não de uso cotidiano antes de serem tido coletadas é o estado das linhas, em especial das franjas: aquelas peças cujo uso era mais recorrente, apresentam-se com o algodão mais enegrecido, algumas delas com até pequenos vegetais nelas grudados.

Atualmente, são dois os principais tipos de linha utilizados pelas mulheres indígenas habitantes do rio Paru de Oeste: as linhas industriais de costura recebem o mesmo nome que as linhas feitas em algodão - maru, palavra que designa tanto a espécie vegetal quanto a linha preparada pelas mulheres (outrora cotidianamente, hoje em dia, são poucas as mulheres que ainda sabem preparar esse tipo de fio); e a linha de pesca, chamadas kewei ewa.

O primeiro tipo de linha é ideal para a tecelagem de keweyu, assim como de cintos, colares, gargantilhas, bandoleiras, alguns tipos de pulseiras e brincos. Para todas essas peças, a preferência é que a linha seja branca, embora cada vez mais as mulheres tenham feito experimentações com outras cores. Essas peças todas implicam num caimento "macio", como dizem essas mulheres, diferentes das pulseiras sem fecho, de cestinhos e de bolsas, que precisam ficar rígidos, sendo, então, tecidos com linha de pesca, que deve ser do calibre certo, conforme o tamanho da miçanga.

De todo modo, o que é essencial em relação à linha, independentemente de seu tipo ou origem, é que esta não deve arrebentar-se com facilidade. Para tanto, quando as mulheres estão na cidade e podem ir em alguma loja para adquirir suas linhas, testa-se as diferentes marcas de linha, tentando arrebentar a ponta do novelo que sai para fora das embalagens. Também é importante que a linha tenha um calibre adequado para passar mais de uma vez por algumas miçangas. Despreza-se as linhas que arrebentam com facilidade e também aquelas que se desfiam rapidamente.

Os fios e as linhas são elementos de grande destaque nas cosmologias ameríndias, constantemente fazendo ligações entre mundos ou planos distintos (Gongora 2016, Kopenawa \& Albert 2003, Gallois 1988), assim como fazendo parte de imagens que ilustram concepções profundas sobre a integralidade e a continuidade da vida (Grupioni 2002; Miller 2007). Além desses locais cosmológicos, fios e linhas são fundamentais na vida cotidiana das aldeias, posto serem imprescindíveis na fabricação dos mais variados artefatos. Um inventário exaustivo dos 
modos como fios e linhas aparecem e são usados pelos povos ameríndios é um trabalho interessante a ser realizado.

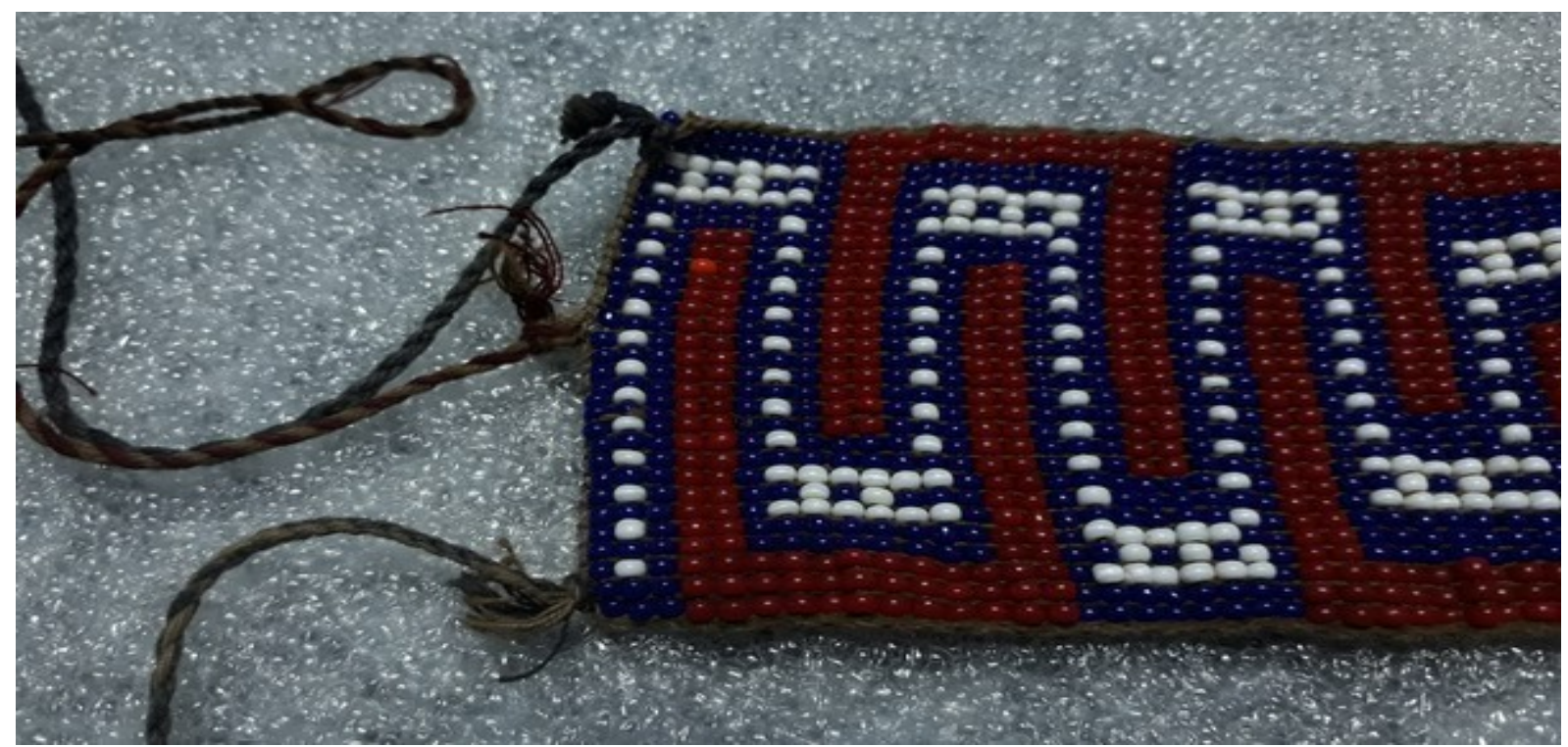

Figura 18: Cinto encontrado na coleção do MPEG, sob $n^{\circ}$ de identificação 7431. Observa-se diferentes tipos de linha em sua composição.

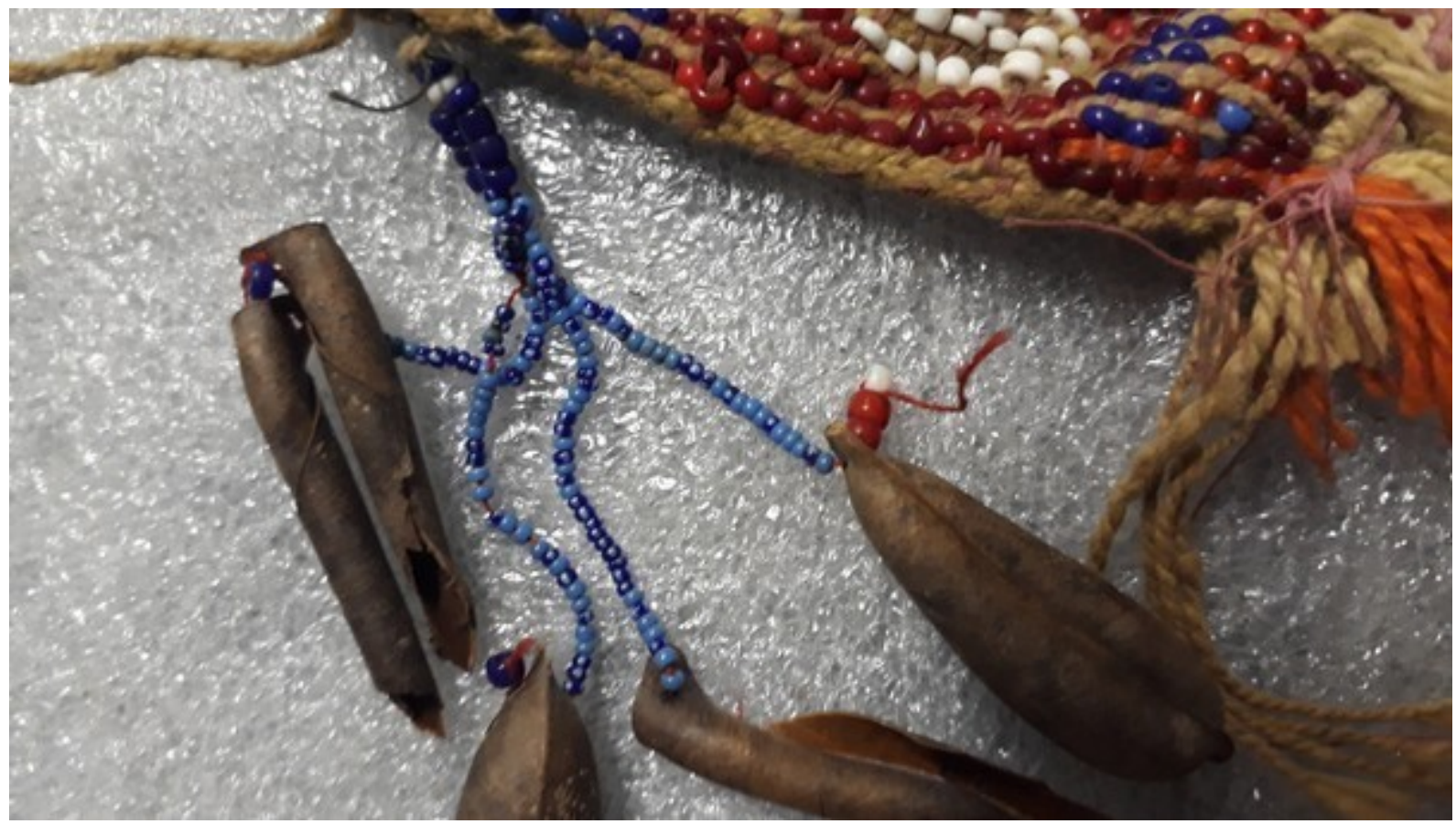

Figura 19: Detalhe de tanga encontrada na coleção do MPEG, onde além dos diferentes tipos de linha, percebese que já havia a circulação de miçangas com tamanho bem inferior ao tamanho 9/0 (corpo da tanga). 
Ao relatar o modo como os espíritos xapiri apresentam-se, Davi Kopenawa destaca a profusão de enfeites, incluindo braçadeiras de miçangas, e o modo como descem para esse mundo:

Milhares deles chegam para dançar juntos, agitando folhas de palmeira novas, soltando gritos de alegria e cantando sem parar. Seus caminhos parecem teias de aranha brilhando como a luz do luar e seus ornamentos de plumas mexem lentamente ao ritmo de seus passos. Dá alegria de ver como são bonitos! (Kopenawa \& Albert 2003, apud Viveiros de Castro 2006).

Essa descrição é coadunada pelo senhor Lucas Tiriyó, conforme nos relatou durante uma oficina em Macapá ${ }^{27}$ : "é que nem teia de aranha, os vários pensamentos que eles usam, os pajés."

Entre os Ye'kuana, encontramos a palavra de uso cotidiano wadeeku, que pode ser traduzido tanto como algodão, linha, quanto por caminho (Gongora, 2016). Há, ainda, o wadeeku ekaato: "fio que liga o duplo do olho à pessoa/corpo. É também o caminho que a pessoa percorre ao refazer os passos já dados por duplo. O 'fio do duplo' é a própria extensão da pessoa."' (p.103). Para os Mamaindê, o estado de saúde das pessoas é diretamente relacionado com a integridade dos enfeites corporais (colares de contas e fios de algodão) que existem dentro dos corpos, sendo diversos os motivos que podem fazer com que os mesmos arrebentem, como levar um susto, sentir vergonha, entristecer-se, consumir alimentos muito quentes, falar alto, dentre outros - sendo que parentes próximos também podem ser afetados por esses arrebentamentos (Miller 2007:143-144). A antropóloga continua:

\begin{abstract}
Os Mamaindê dizem que essa linha de algodão (kunlehdu), que o pajé enxerga como um colar de contas pretas (yalikdu) é o nosso rumo, a nossa memória e também aquilo que nos faz sonhar. Sem ela não sabemos mais onde estamos, deixamos de reconhecer nossos parentes, ficamos perdidos, doentes. Quando isso acontece, dizse que a pessoa perder o seu "espirito" (yauptidu) ou as suas "coisas" (wasain'du). (p.146).
\end{abstract}

Em relação à arte da tecelagem com miçangas das mulheres Tiriyó e Katxuyana, Grupioni (2016) assim descreve:

Para as mulheres tiriyó, a vida é feita de fios: fios de algodão (maru) com que tecem suas peças. E fios vitais, como o sangue (munu), com que tecem suas vidas. Nesta via simbólica, em que tecer é dar vida, contas de miçangas (samura), assim como gotas de sêmen (kuru) preenchem os fios que, entrelaçados, originam coisas e pessoas pelas suas próprias mãos. Assim, fios (de algodão e de sangue) não se espalham em vão. Isso seria o caos. Por isso, a arte da tecelagem imita a arte da socialidade e vice-versa, já que um tear é como uma aldeia: em ambos se tecem

27 Essa oficina aconteceu em janeiro de 2019, na CASAI de Macapá, quando apresentei para mulheres e demais pessoas interessadas o estado atual da pesquisa. 
relações, seja entre coisas, seja entre pessoas: o algodão e a miçanga; a mulher e o homem; o sangue e o sêmem.(p. 185-186).

Ainda sobre os Tiriyó, em sua tese de doutorado, Grupioni (2002) conta não apenas que é o sangue que faz com que o espírito continue (p.15), como também destaca exatamente essas continuações como centrais no que chama de "Sistema e Mundo da Vida Tarëno". Itïpï é a palavra em língua tiriyó que designa essas continuações, que podem se referir tanto às diferentes yana (gentes), quanto aos braços de um rio, ou mesmo os galhos de árvores, ramificando-se. No capítulo seguinte, as aproximações entre esse sistema e mundo da vida tarëno e os usos das miçangas serão aprofundados.

\section{Pendentes}

Outros materiais também aparecem nas peças tecidas em miçangas, sobretudo nos keweyu. A maior parte dela são sementes, que ornamentam as laterais e a parte inferior dessa peça, provocando um bonito efeito sonoro quando as mulheres andam e dançam. Foram-me enumerados 12 diferentes tipos de sementes: sawawaimë, maramara, makuipana, aturaimë, kupapi, ampere, parakaru, marapaimë, wëtëi, arekore enu, aweke, sirisiri ipifë.

Partes de animais eram mais utilizadas antigamente, mas ainda podem ser eventualmente encontradas em alguns adornos: dentes de macaco (taripi ie), dentes de onça (kaikui ie), dentes de porco-do-mato (ponyeke ie), vértebra de peixe (kana ietipï) e vértebra de jiboia (kïwïnï ietipi), além de penas de diversos tipos de periquitos e de tucanos, e élitros de besouro (sirisiri ipifë). As conchas de caramujo chamadas kue praticamente não são mais utilizadas, mas apareciam num tipo de brinco chamado panatura, que ligava uma orelha a outra por meio de alguns fios de miçangas brancas, passando abaixo do queixo. Um exemplar deste adorno encontra-se no acervo do Museu Paraense Emilio Goeldi (n. 9154).

Entre os elementos industriais apreciados para ornamentação das franjas e laterais dos keweyu, destacamos os guizos, em seus variados tamanhos, e também tampinhas de metal. O alumínio é um material que já foi utilizado para a fabricação de pulseiras e brincos, obtido pelas trocas com os mekoro. Vindo na forma de maletas de alumínio, elas eram desfeitas e transformadas nos adornos mencionados.

As mudanças nos materiais utilizados para a composição dos adornos apreciados por esses povos indígenas não lhes causam nenhum sentimento de perda cultural. Pelo contrário, 
quando questionadas a respeito de não mais utilizarem elementos, tais como os élitros de besouro, elas apenas dizem que podem voltar a utilizar a hora que quiserem, tratando-se muito mais de preferências que podem alterar-se, como modas.

\section{Samura Rïtohton - Assim tecemos miçangas}

Nesta seção, serão apresentadas as técnicas de tecelagem atualmente utilizadas pelas mulheres tiriyó, katxuyana e txikiyana que moram na região da Missão Tiriyó e arredores. Dadas as semelhanças nas peças produzidas pelas mulheres de outras aldeias e regiões, podese entender que essas técnicas têm vasta amplitude geográfica, certamente com pequenas variações. Através da observação e análise das peças que constam no acervo técnico do Museu Paraense Emílio Goeldi, também se percebe que essas técnicas têm mantido-se através do tempo, principalmente aquelas que fazem uso de teares. A introdução das técnicas que não fazem uso desse equipamento é ligada a chegada de irmãs missionárias, conforme me relatou Manuel Muí Kaxuyana.

\section{Técnicas de Tecelagem}

São duas as principais técnicas: samura amoitëfë e samura tïkepüfë, sendo que dentro desta segunda técnica, existem diversos procedimentos, implicando na utilização de instrumentos variados.

\section{Samura Amoitëfë}

Consiste em enfilar miçangas num único fio, com ou sem o auxílio de uma agulha. É a primeira técnica que as meninas aprendem, quando ainda são pequenas. Pode ser tanto de uma única cor quanto formando padrões sequenciais, ou mesmo exibindo cores aleatoriamente colocadas no fio. É comum encontrar senhoras mais velhas utilizando pulseiras e colares feitos de miçangas misturadas, feitos por suas netas. Os principais adornos feitos com essa técnica são ëmëna, aiyi amoitëfë, iyafan (Fig. 20). Sobre os diferentes modos de dispor as cores, nota-se que a preferência para uso interno é pela utilização de uma única cor, enquanto para venda são os padrões de cores sequenciais; as miçangas misturadas aleatoriamente são feitas sobretudo pelas meninas que estão iniciando o aprendizado do trabalho com miçangas, e utilizadas principalmente por suas avós. Poucos exemplares são encaminhados para a venda. 


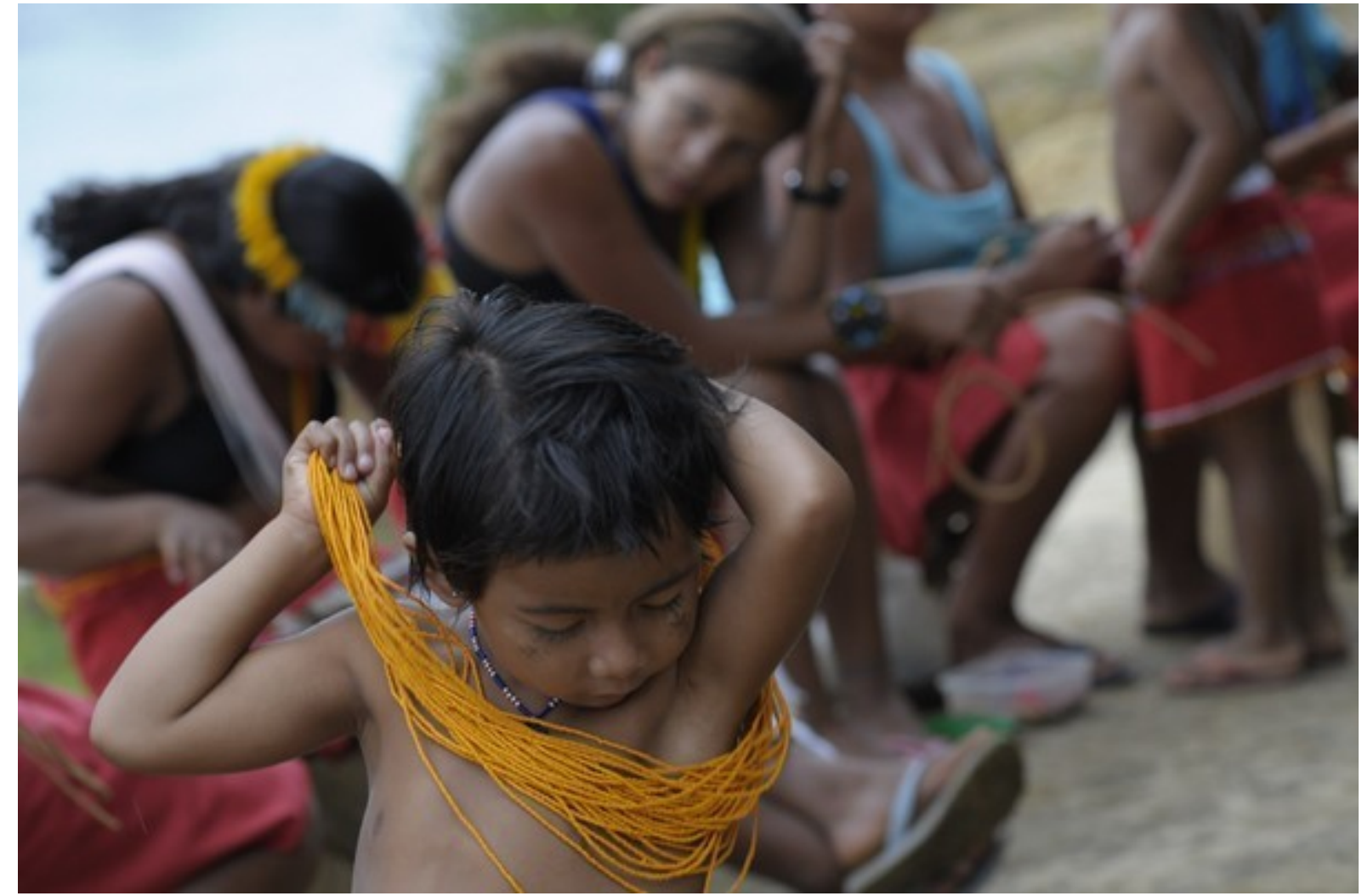

Figura 20: Criança colocando iyafan. Aldeia Santo Antonio, 2010. Acervo Iepé. 


\section{Samura Tïkapïfë}

Essa técnica se refere de modo geral aos objetos cuja fabricação implica na elaboração de uma trama. A palavra tïkapïfë aplica-se também a outros objetos, como telhado de palha ou cestarias, como o tipiti (matapi). As principais peças feitas com miçangas são: ëmëna, panti, aiyi tïkapïfë, keweyu tïkapÿfë. A execução dessa técnica resulta de diferentes processos, descritos abaixo:

2.1 Tëgen akusa: com uma única agulha. A maior parte dos objetos feitos com miçangas pelas mulheres tarëno implica na utilização de uma agulha em sua fabricação. Os trabalhos feitos com a utilização de uma agulha podem ser divididos em dois tipos:

2.1.1 Tepuken: feitos com epu, isto é, com teares. Tal é o caso do keweyu (saia frontal feminina) (Figs. 21 e 22), de certos tipos de ëmëna (pulseira) (Fig. 23) e do panti (cinto masculino) (Fig. 24).

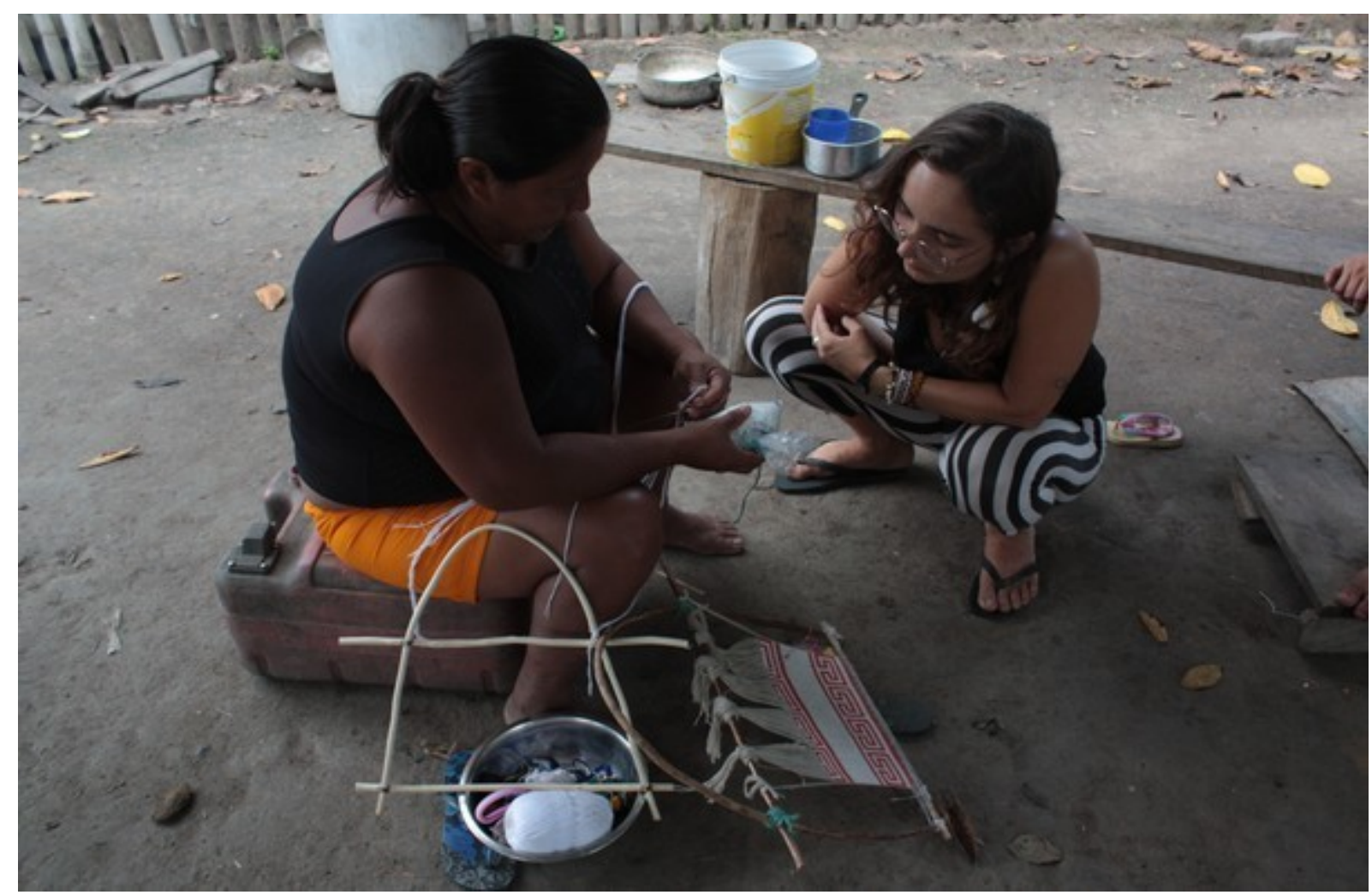

Figura 21: Lurdes Kaxuyana me explica sobre cores das miçangas, antes de começar a armar o keweyu em seu tear. A armação mais clara, à direita, é do keweyu que ela me ensinaria a tecer. A outra, com um keweyu em processo de feitura, ela está fazendo para sua filha. Foto de Jacilene Parena Kaxuyana Tiriyó. Janeiro de 2019. 


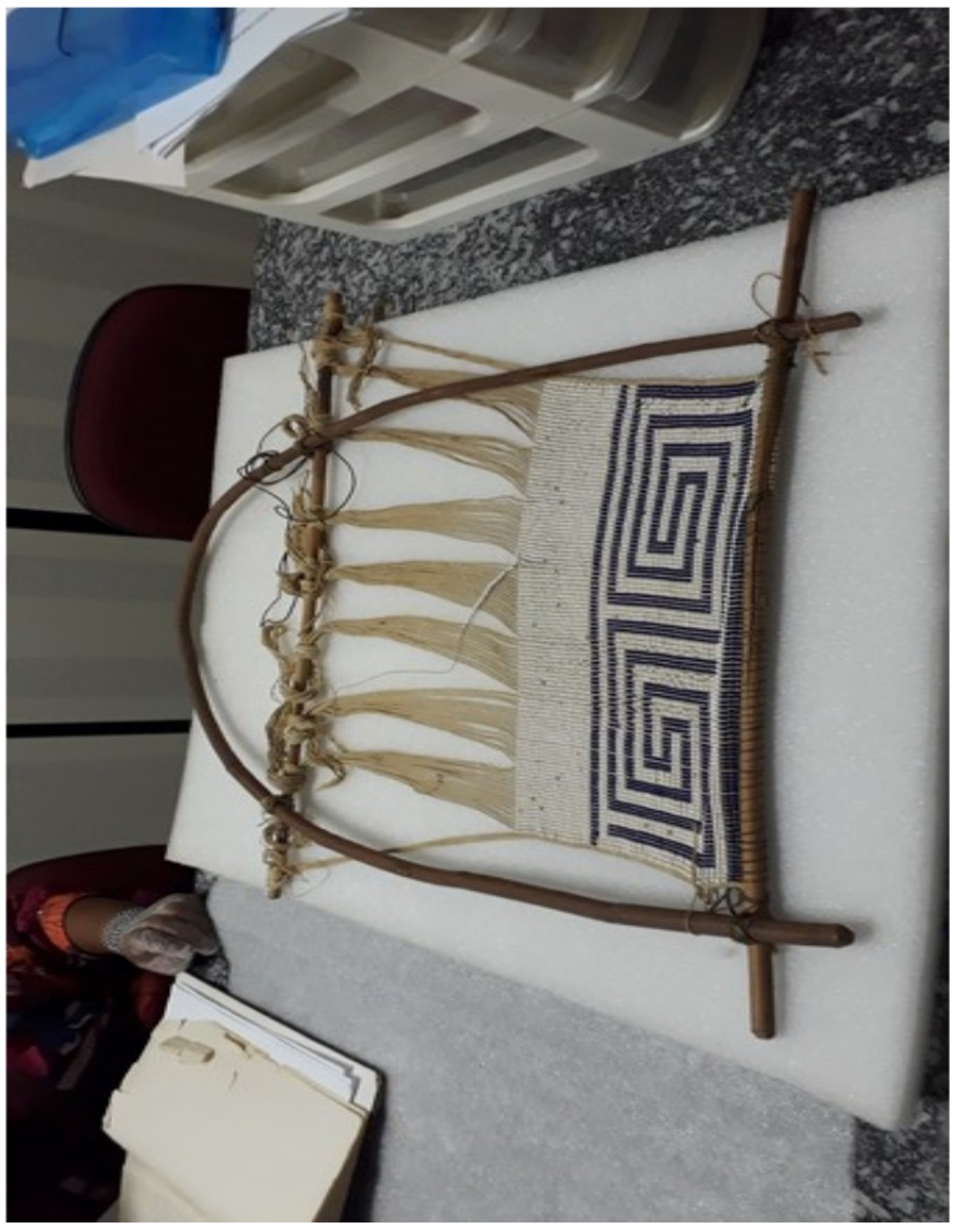

Figura 22: Keweyu em sua armação, no acervo do Museu Paraense Emilio Goeldi (identificação: 9381). Junho de 2019. 


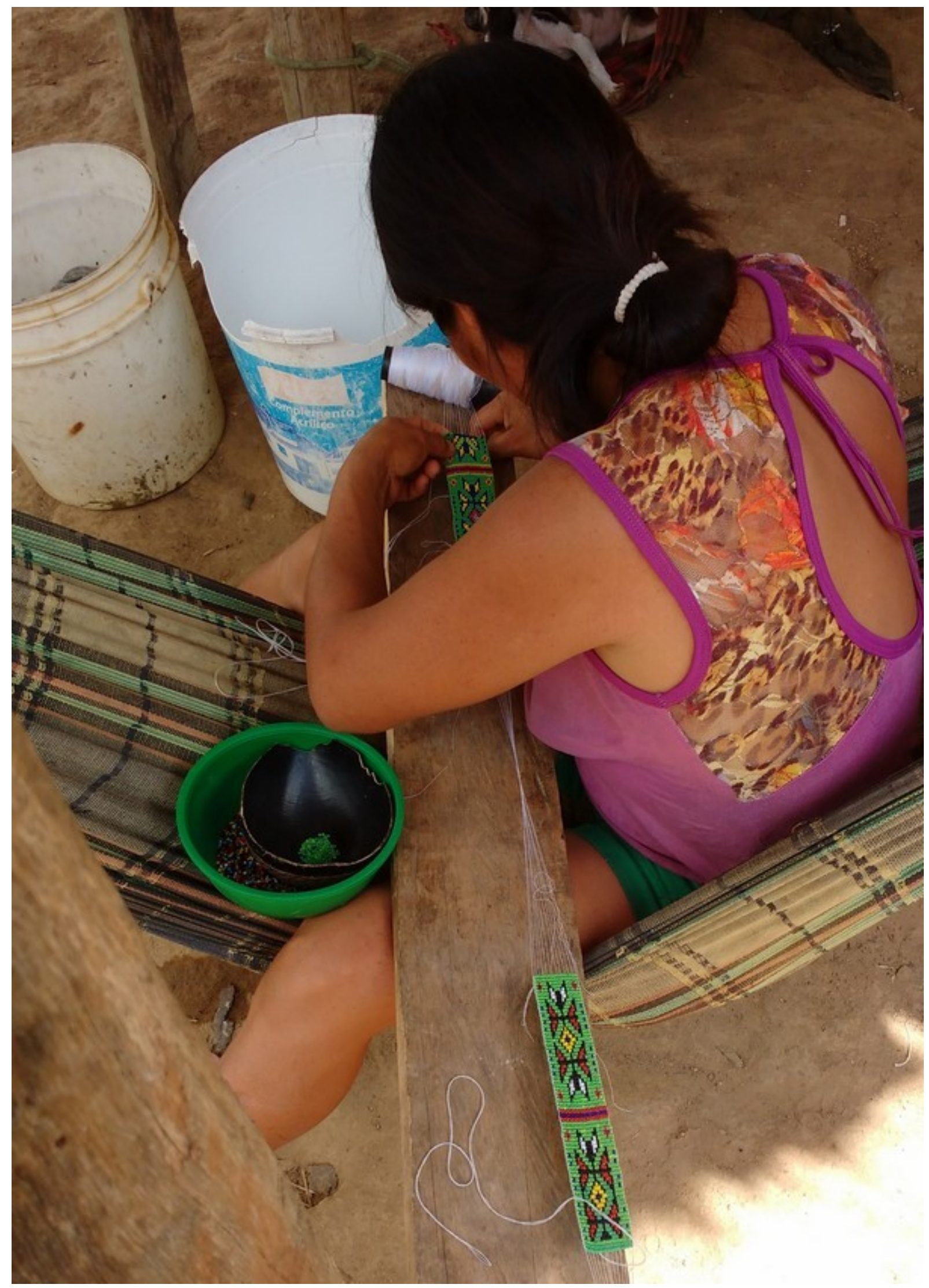

Figura 23: Tecendo um cinto. aldeia Santo Antonio, março de 2017. 


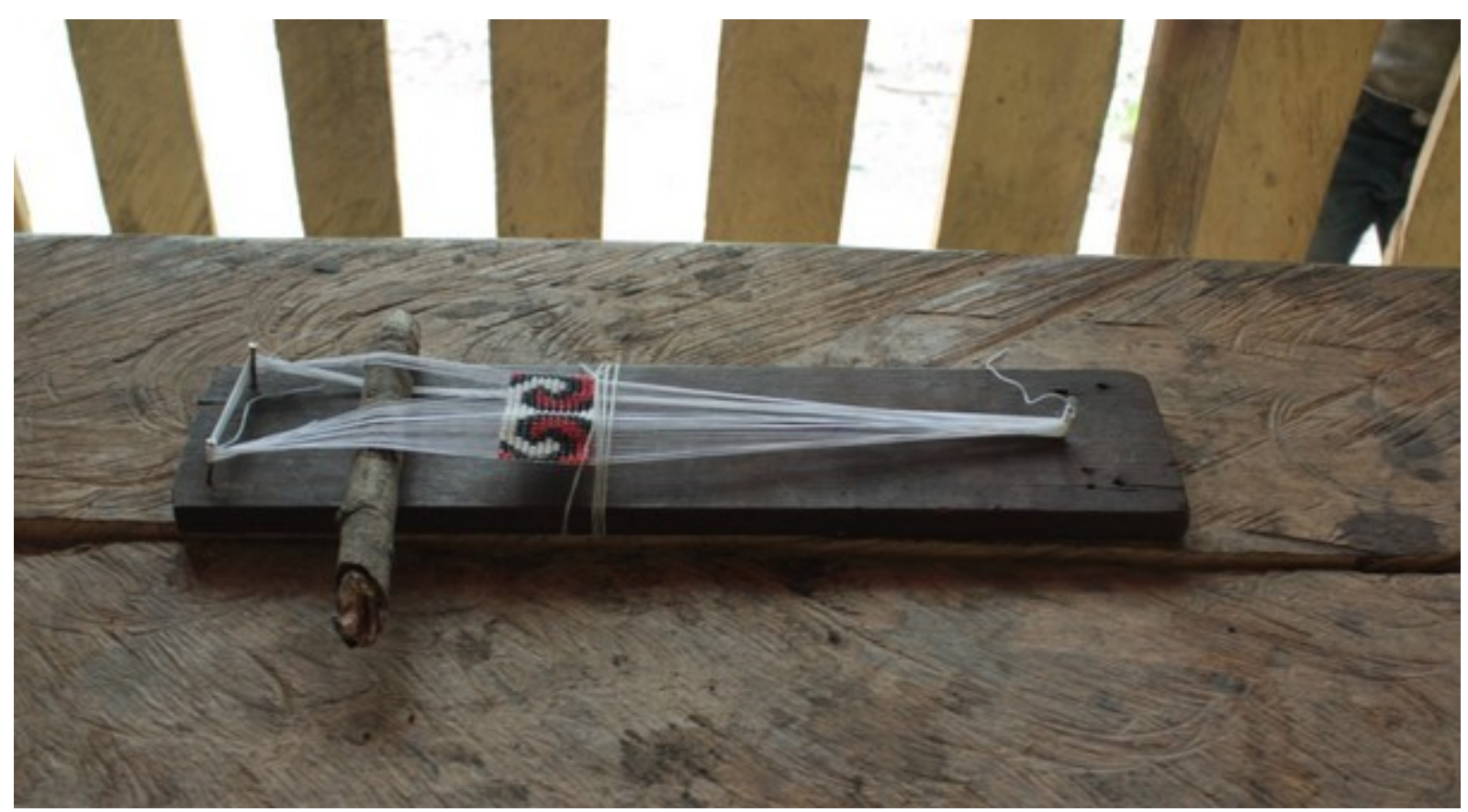

Figura 24: Pulseira sendo preparada em seu tear. Aldeia Missão Tiriyó, janeiro de 2019. 
2.1.2 Epuruna tïkapïfë (Figs. 25 e 26): feitos sem epu, isto é, sem teares. São produzidas dessa maneira peças como pulseiras, brincos, colares, bolsas, cestos. Embora as peças de miçangas mais caraterísticas da região sejam os keweyu e os panti, feitos em teares, o maior volume de peças certamente é produzido com a utilização de uma agulha e sem teares.

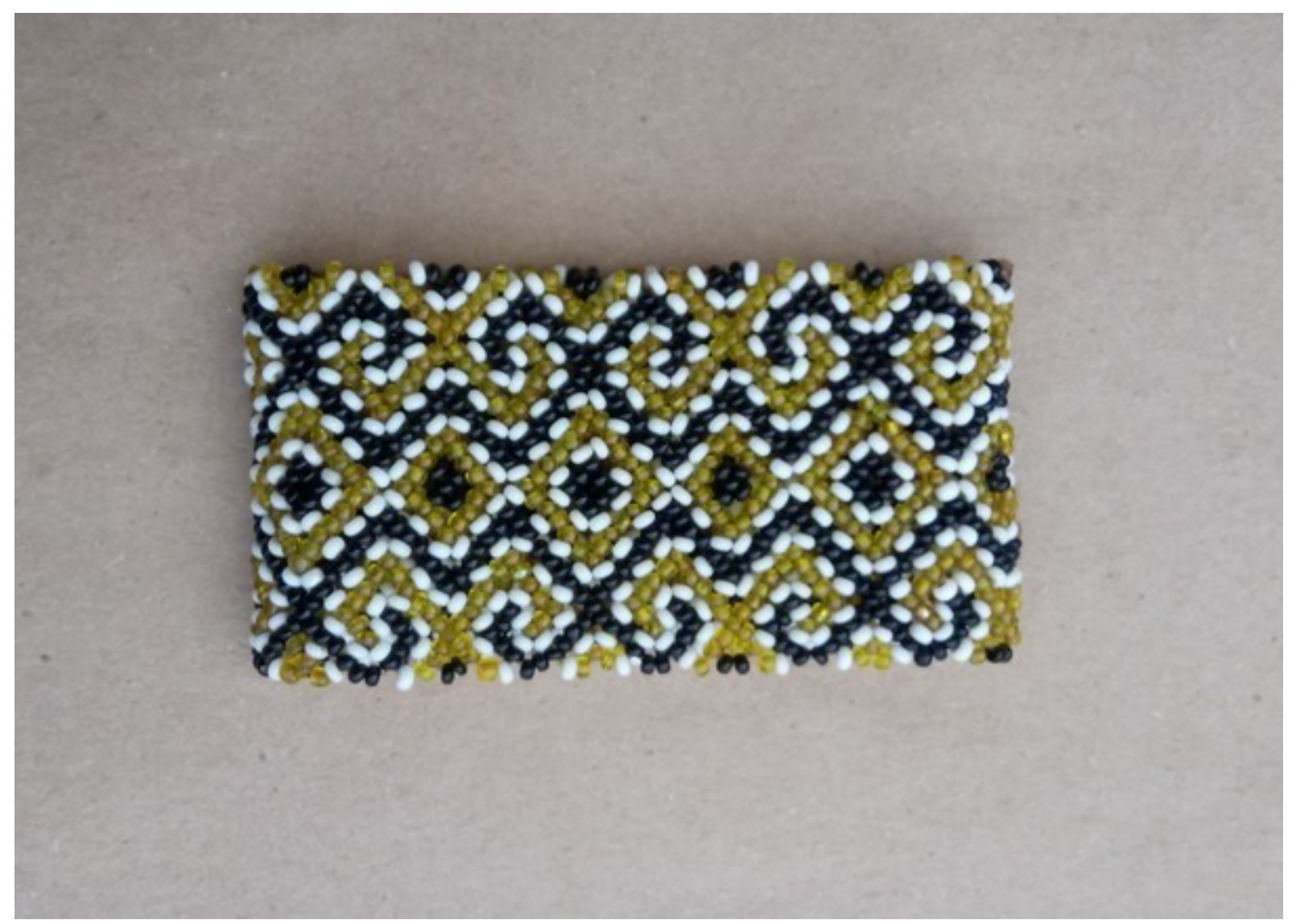

Figura 25: Pulseira tecida por Isabela Naya Tiriyó Kaxuyana. Padrão gráfico: tuna rere. 


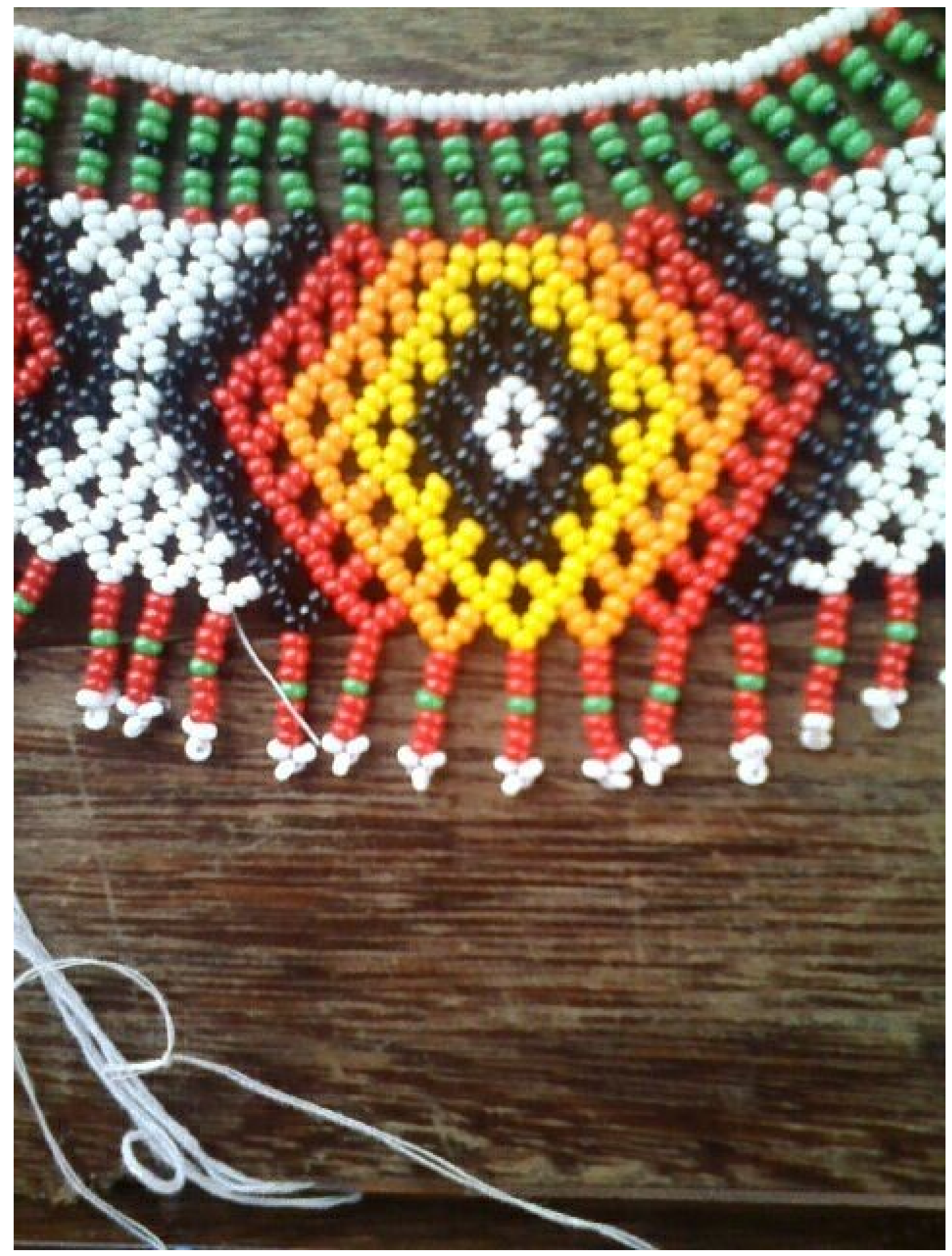

Figura 26: Detalhe de colar sendo tecido por Rosineide Saripun Kaxuyana Tiriyó. Foto: Rosineide Saripun Kaxuyana Tiriyó. 
2.2 Tïwereken akusaton (Fig. 27): com duas agulhas. Não é muito comum encontrar peças produzidas com a utilização de duas agulhas. Essa técnica é considerada mais difícil, e é encontrada sobretudo em peças como pulseiras, copiadas de outros povos indígenas. Não são muitas as mulheres que dominam a técnica, e pode-se dizer que é mais difundida entre mulheres mais jovens e que moram em cidade.

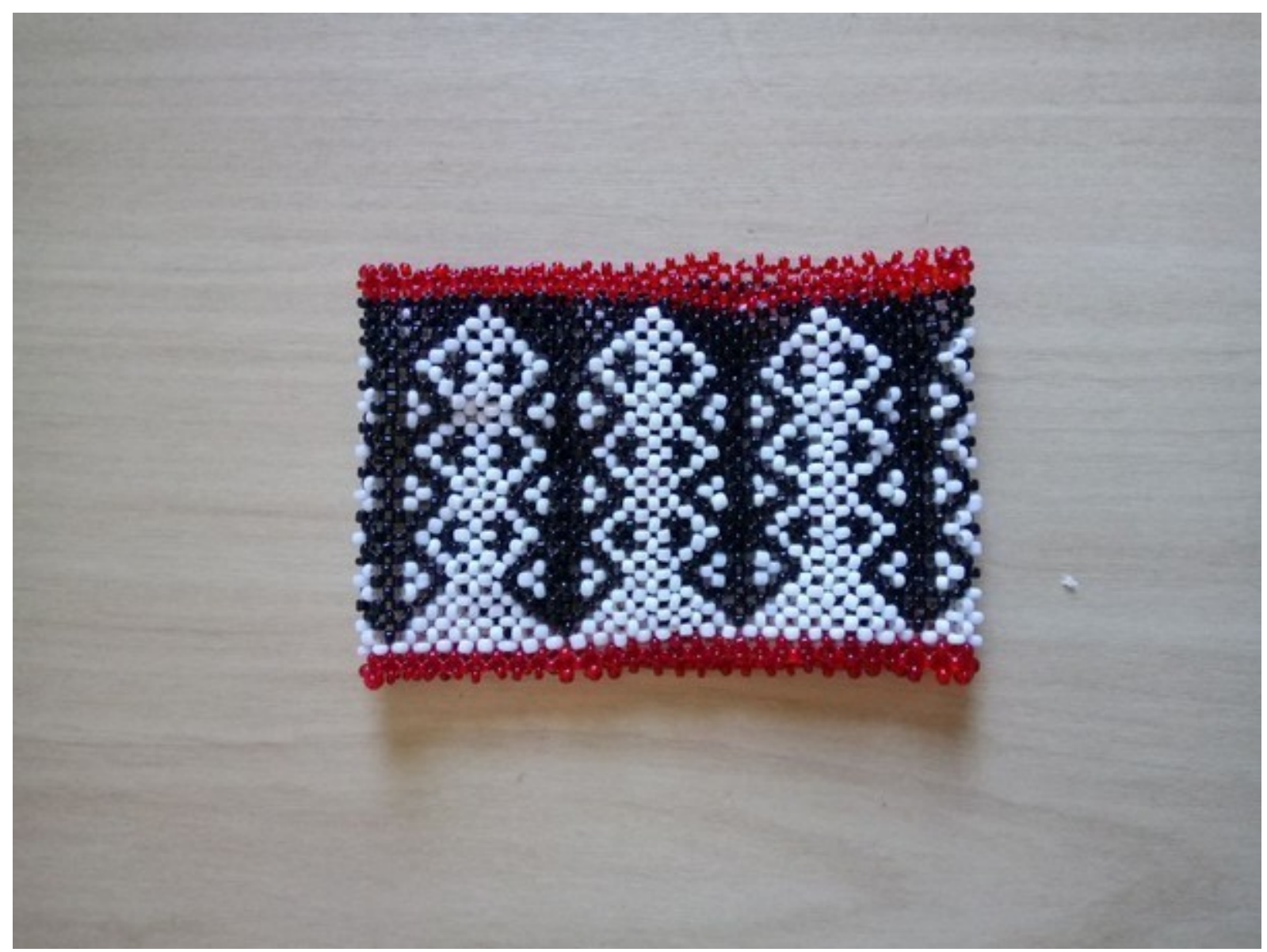

Figura 27: Pulseira tecida por Arawaje Wayana Aparai, a partir de motivos que ela conhecen em viagem ao Acre (Encontro de Mulheres Indígenas). Agosto de 2017.

\section{Padrões gráficos em circulação}

Exemplificar similaridades formais entre padrões que podem ser encontrados nas pinturas e na cultura material dos Wajãpi, Wayana, Aparai, Tiriyó e Katxuyana pode esbarrar nos limites das técnicas empregadas. Esses limites, contudo, possibilitam que se perceba as formas como se comunicam os objetos fabricados por esses povos indígenas, que em suas 
extensas redes de relações fazem com que circulem não apenas objetos e pessoas, mas também saberes materiais e imateriais que compõem seus modos de vida.

Déléage (2007:7-10) elabora tabelas comparativas entre repertórios de padrões gráficos de diferentes povos da bacia amazônica, evidenciando como os sistemas gráficos dessa região funcionam enquanto sistemas de diferenças (idem:15). A seguir, fazendo o mesmo exercício para a região do sudeste das Guianas, aparecem alguns padrões gráficos eminentemente semelhantes, embora elaborados por pessoas de diferentes origens:

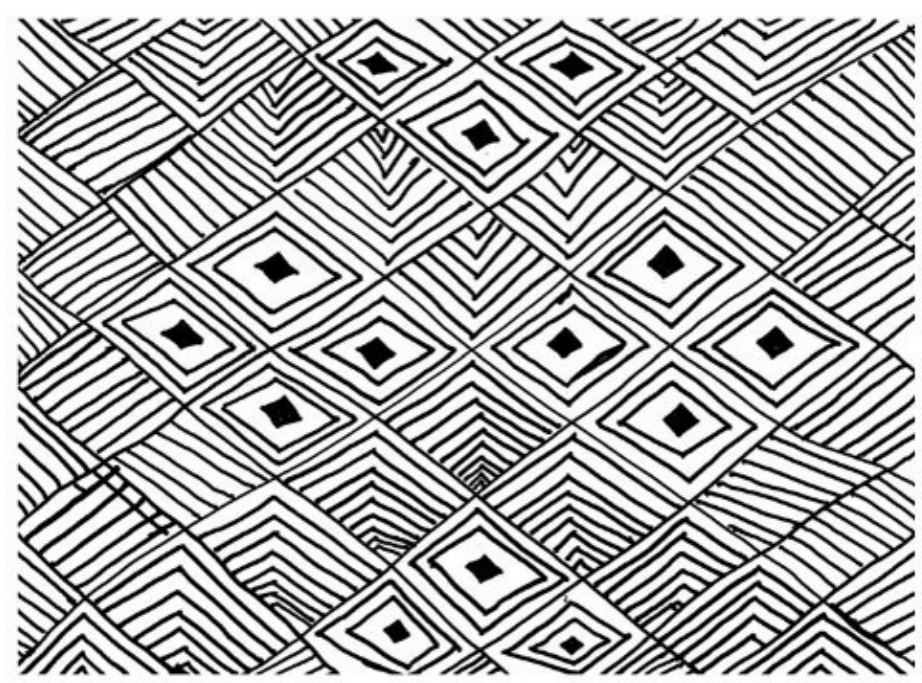

Figura 28: Padrão wajãpi denominado urupe aravekwa (ânus da peneira). Autor: Karaviju Wajãpi. IPHAN 2000:53.

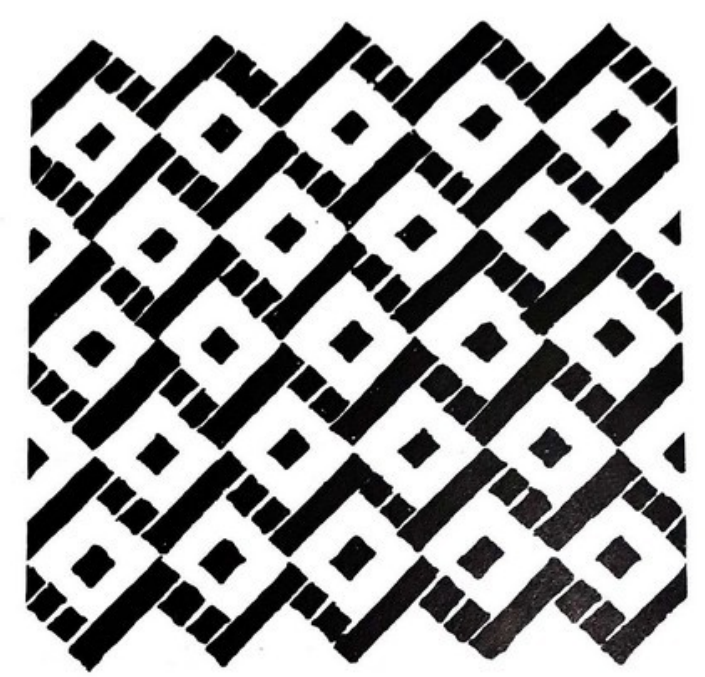

$\mathrm{N}^{\circ} 20$ - KURÍ PUTPË (W) - KURIRÚ PITPURE (A) Casco de jabuti/ente sobrenatural

Figura 29: Padrão conhecido em língua wayana como kuri putpë, e em língua aparai como kuriru pitpure (caso de jabutilente sobrenatural). Velthem 1998:150. 


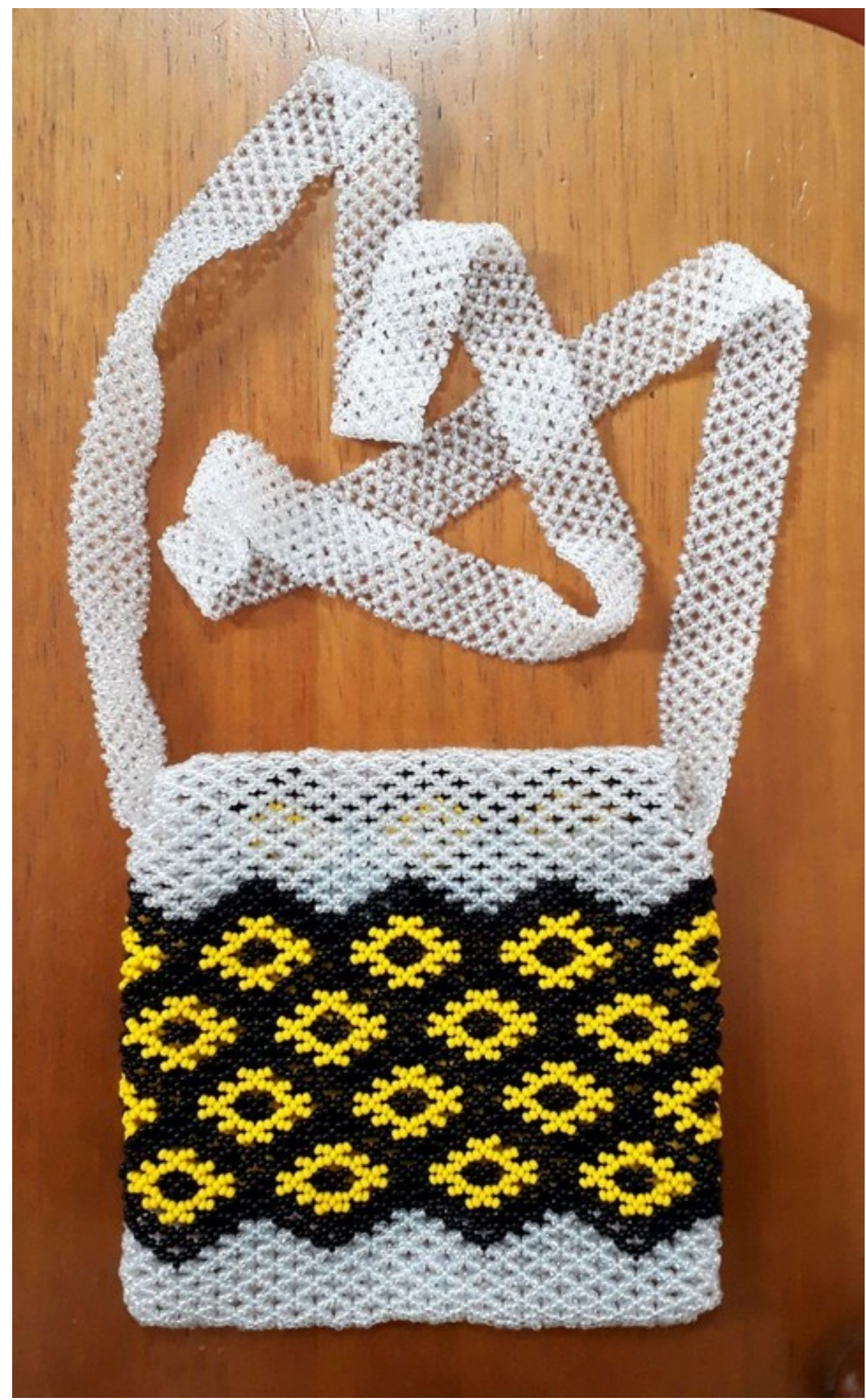

Figura 30: Verso de bolsa tecida em miçangas por Isabela Naya Tiriyó Kaxuyana (2017), com o padrão conhecido em língua tiriyó como taripi enu (olho de macaco). 
As redes de relações entre os povos indígenas guianenses, em especial no sudeste da região, compõem-se de trocas comerciais, guerras e casamentos, através dos quais circulam pessoas, objetos e conhecimentos. O seguinte padrão também é exemplo dessa circulação, afinal seu nome entre os Tiriyó é aparai imenu, isto é, desenho dos Aparai:

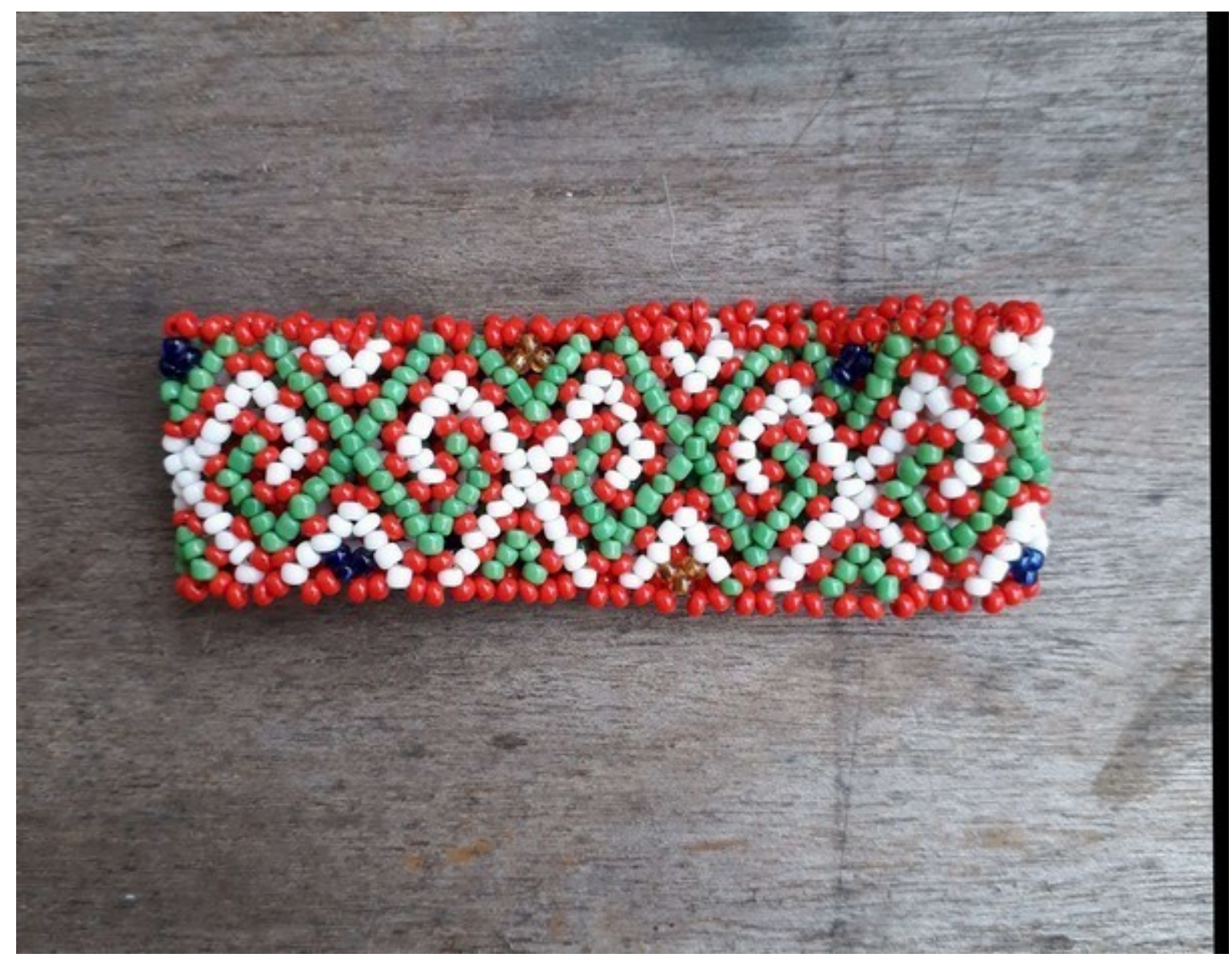

Figura 31: Pulseira com o padrão aparai imenu (desenho dos Aparai), feita por Rosineide Saripun Kaxuyana Tiriyó e por mim. Aldeia Santo Antônio, 2014.

Os quatro padrões gráficos aqui representados já trazem uma característica comum a todos os sistemas gráficos guianenses, conforme mencionado acima: para todos esses povos indígenas, os padrões de que fazem uso para enfeitar seus corpos e os corpos de variados objetos não lhes pertencem, mas sim foram capturados de outros seres, humanos e nãohumanos, mas marcadamente com características sobrenaturais ${ }^{28}$.

28 Assim, embora Déléage (2007) frise o caráter mnemotécnico dos nomes dos padrões gráficos, não podemos deixar de destacar a referência constante que os nomes fazem a outros seres. 
Não é à toa que as histórias indígenas que dão conta da origem desses padrões gráficos remetem, em sua maioria, a encontros com Anacondas, como o caso do Tuluperê dos Wayana e Aparai (Velthem 1998, 2003; Velthem \& Linke 2010) ou mesmo dos Wajãpi (IPHAN, 2008; Gallois, 2012), ainda que no primeiro caso os padrões tenham vindo da pele da Cobra Grande, enquanto que no segundo caso, eles vêm de suas entranhas. Grupioni (2009:32-40) indica as variadas narrativas ligadas às origens dos padrões gráficos para os povos indígenas da região oeste da TI Parque do Tumucumaque:

(...) contam os Prouyana que algumas de suas pinturas aprenderam com os Okomoyana, outras com os Maraso, outras com os Akïó, e outras com os Wayana mais antigos, mas que antes de conhecerem os Aramayana, pintavam seus corpos apenas com urucum, e que foi com eles que aprenderam as primeiras técnicas e motivos de pintura corporal com jenipapo. Também os Sakïta e Txikuyana atuais contam que foi com os Aramayana que aprenderam a se pintar. Os Aramayana, por sua vez, hoje dizem não saber com qual povo aprenderam a arte das pinturas corporais, mas consideram que seus padrões foram extraídos da pele das cobrasgrande que existiam nos tempos de seus antepassados mais remotos. Já os Kaxuyana contam que aprenderam seus padrões com seus ancestrais não apenas Kaxuyana, mas Werikiyana, Ingaruiyana, Yaskuriyana e vários outros que, por sua vez, teriam 'tirado' seus diferentes grafismos de algumas cobras-grande, tão monstruosas e temidas, quanto belas e sedutoras, que moravam em poços, situados nos rios de sua região.(Grupioni 2009:34)

\section{Controvérsias na patrimonialização de saberes em rede}

Gallois $(2007,2012,2015)$ trata dos imbróglios que aparecem no encontro entre esses sistemas gráficos e as políticas públicas de valorização cultural, que necessariamente vinculam elementos culturais com identidades étnicas - que passam a ser construídas por (e para) esses povos exatamente quando da necessidade de relacionar-se com o Estado Nacional:

[Os padrões gráficos] São elementos que pertencem a outros e foram literalmente capturados ou resultam de fluxos complexos de intercâmbio. (...) são saberes e práticas que não poderiam, logicamente, ser nem deles [dos Wajãpi], nem de outros grupos. Não só porque são produto das redes de troca entre humanos $e$ sobrenaturais, como porque são gerados e apenas expressados no âmbito desse sistema de trocas, entre pessoas, entre grupos, entre humanos e não humanos. (2007: 97-98)

O movimento da etnificação promovido por essas políticas públicas têm provocado situações complexas entre esses povos. Os Wajãpi tiveram sua arte gráfica kusiwa registrada como Patrimônio Cultural Imaterial pelo IPHAN em 2002, processo que se deu a partir de dossiê enviado pelos próprios Wajãpi à UNESCO e ao instituto federal. Passados dez anos de seu registro, o registro revalidado, conforme interesse dos Wajãpi, mantendo-se o apoio do governo federal à salvaguarda do kusiwa. 
Um dos produtos advindos do reconhecimento do Estado de que determinada manifestação é patrimônio cultural, material ou imaterial, do Brasil, é a elaboração da publicação física do dossiê dessa manifestação. No caso da arte gráfica kusiwa, temos várias publicações ${ }^{29}$ que descrevem essa manifestação gráfica, o repertório de padrões e seus modos de composição, além do processo da patrimonialização. Um dos efeitos causados por essas publicações acaba por ser certo ciúme entre os povos karib da região, quando verificaram nos catálogos a semelhança entre os padrões usados pelos Wajãpi com os seus próprios padrões. E vemos a situação acontecendo novamente nos dias de hoje, quando está em fase final de elaboração o Dossiê da Arte Gráfica Wayana e Aparai, a pedido da Associação dos Povos Indígenas Wayana e Aparai (APIWA). Pude acompanhar a última oficina referente a esse processo, e era visível o constrangimento, ou mesmo indignação dos participantes Tiriyó das cabeceiras do rio Paru de Leste em se verem contemplados nesse inventário, apesar de reconhecerem padrões gráficos já inventariados pela antropóloga Lúcia Van Velthem.

Semelhanças nos repertórios iconográficos dos povos karib do sudeste das Guianas também evidenciam uma separação entre dois tipos de repertórios, a saber, de um lado padrões gráficos propriamente ditos e, do outro, padrões figurativos. Essa distinção pode ocorre nos repertórios dos Tiriyó, Kaxuyana, Wayana e Aparai, e aliás, entre quase todos os povos da região, ou mesmo nos sistemas gráficos amazônicos (Déléage 2007:7; Lagrou 2011).

Entre os Tiriyó, esse primeiro repertório abrange os padrões chamados imenuton, fazendo referência ao jenipapo, utilizado para a execução de pinturas corporais, do mesmo modo que em wayana, milikut, e aparai, menuru. Já o segundo, é denominado, em língua tiriyó, ikuhtu ou pampiram imenuton - figuras tiradas do papel; acepção comum aos nomes em línguas wayana e aparai, respectivamente, pampiram imilikut/ pampiram menuru. Esse segundo repertório faz referência aos desenhos tirados dos livros de ponto-cruz trazidos por missionários e utilizados, sobretudo, nos cintos masculinos, mas também em colares e pulseiras (Grupioni 2009, Van Velthem \& Linke 2010).

No que diz respeito ao modo como os elementos desses repertórios são manejados nas peças produzidas com miçangas, temos variadas situações. Nas saias frontais, tanto nos keweyu tiriyó, quanto nos monenoho katxuyana, ou nos weju wayana e aparai, são usados apenas padrões gráficos, e não desenhos figurativos. Nas peças tiriyó, os principais motivos encontrados são pakara imenu (pintura de cesto), arimi aroki (rabo de macaco coamba),

29 Gallois (2002), IPHAN (2008). 
kaikui ipana (orelha de onça), dentre outros. Nas peças wayana e aparai, vemos com frequência desenhos de onças-lagartas sobrenaturais, como kaikui/kaikuxi, mas também kaikui ipana.

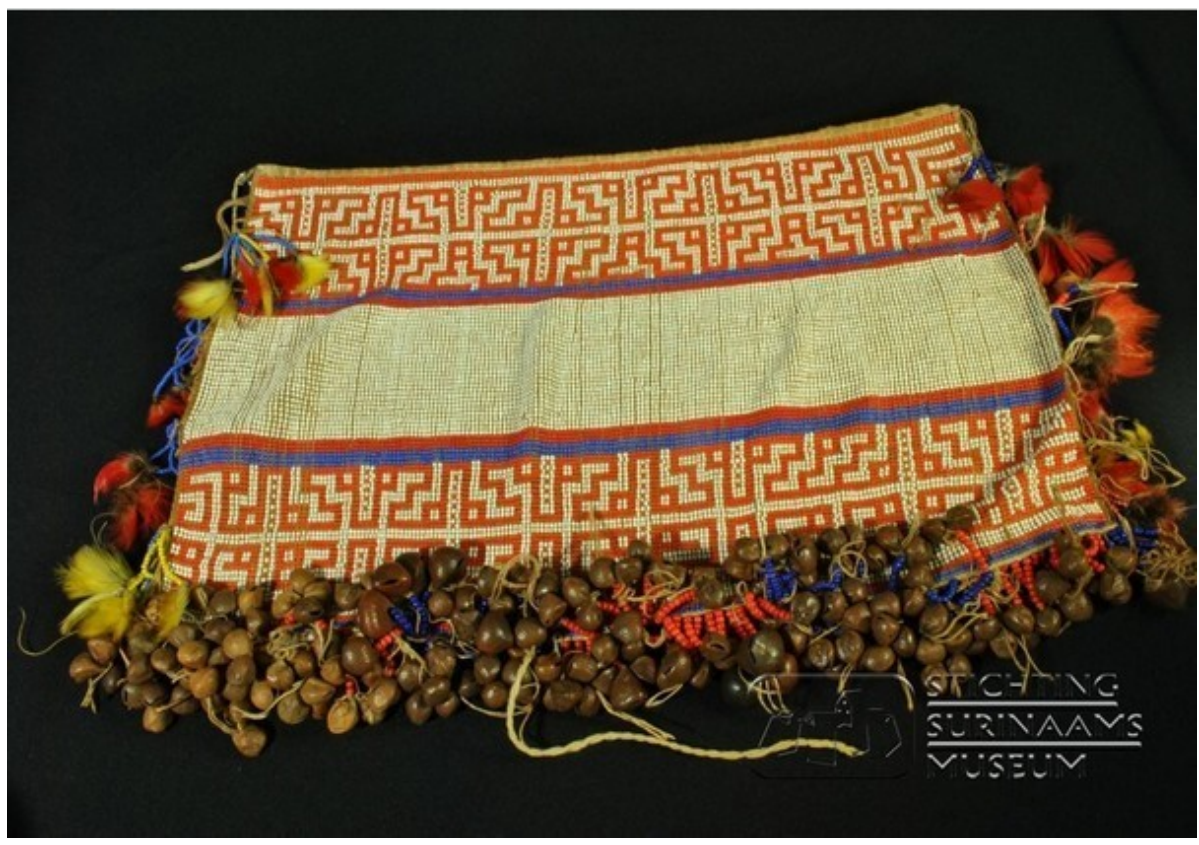

Figura

Keweyu tiriyó, com o padrão pakara imenu (desenho de cesto), disponivel no Stichting Surinaams

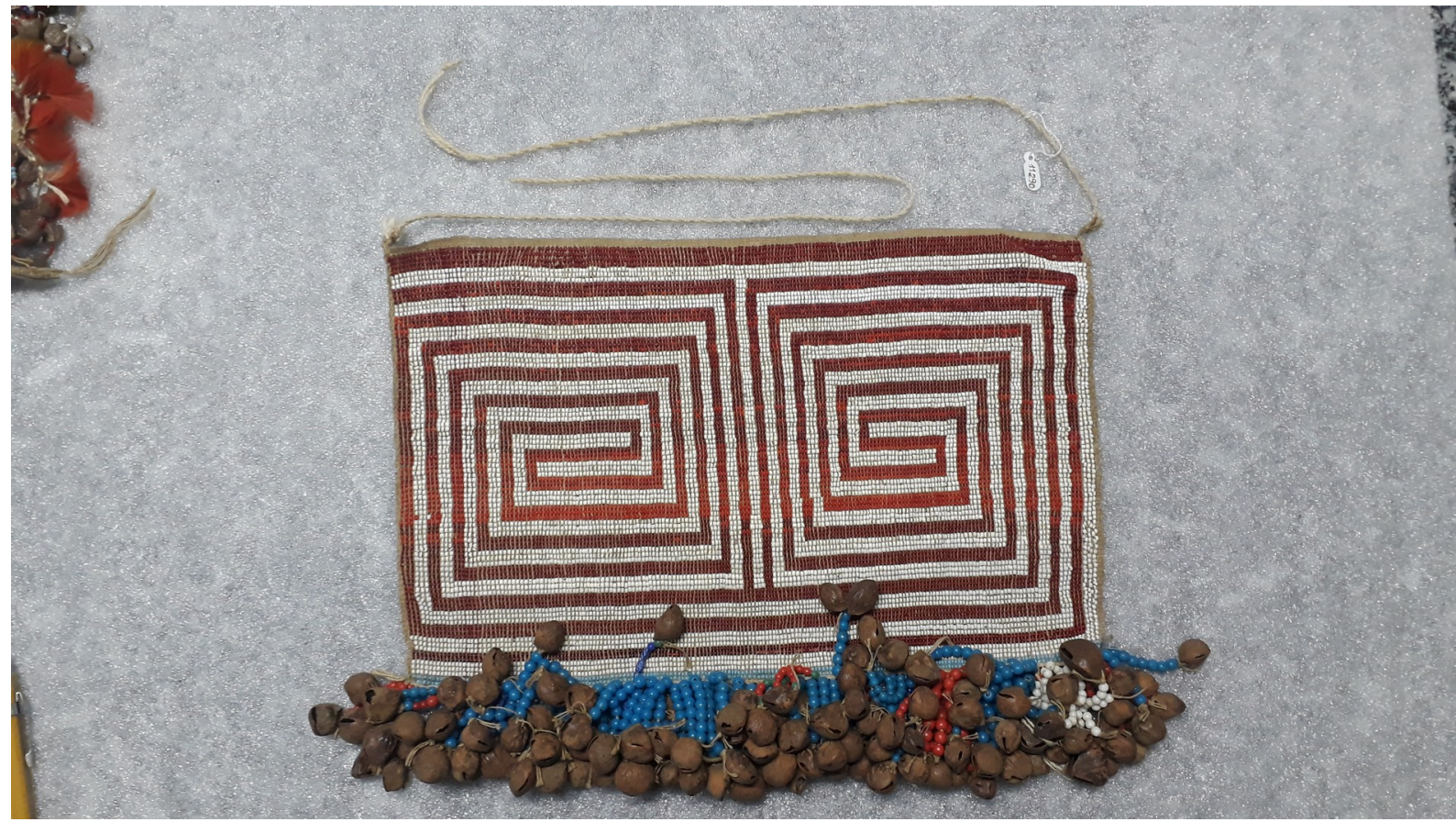

Figura 33: Keweyu tiriyó (acervo MPEG, $n^{\circ}$ 11290), com padrão arimi aroki (rabo de macaco coamba). Coletado em 1965. 


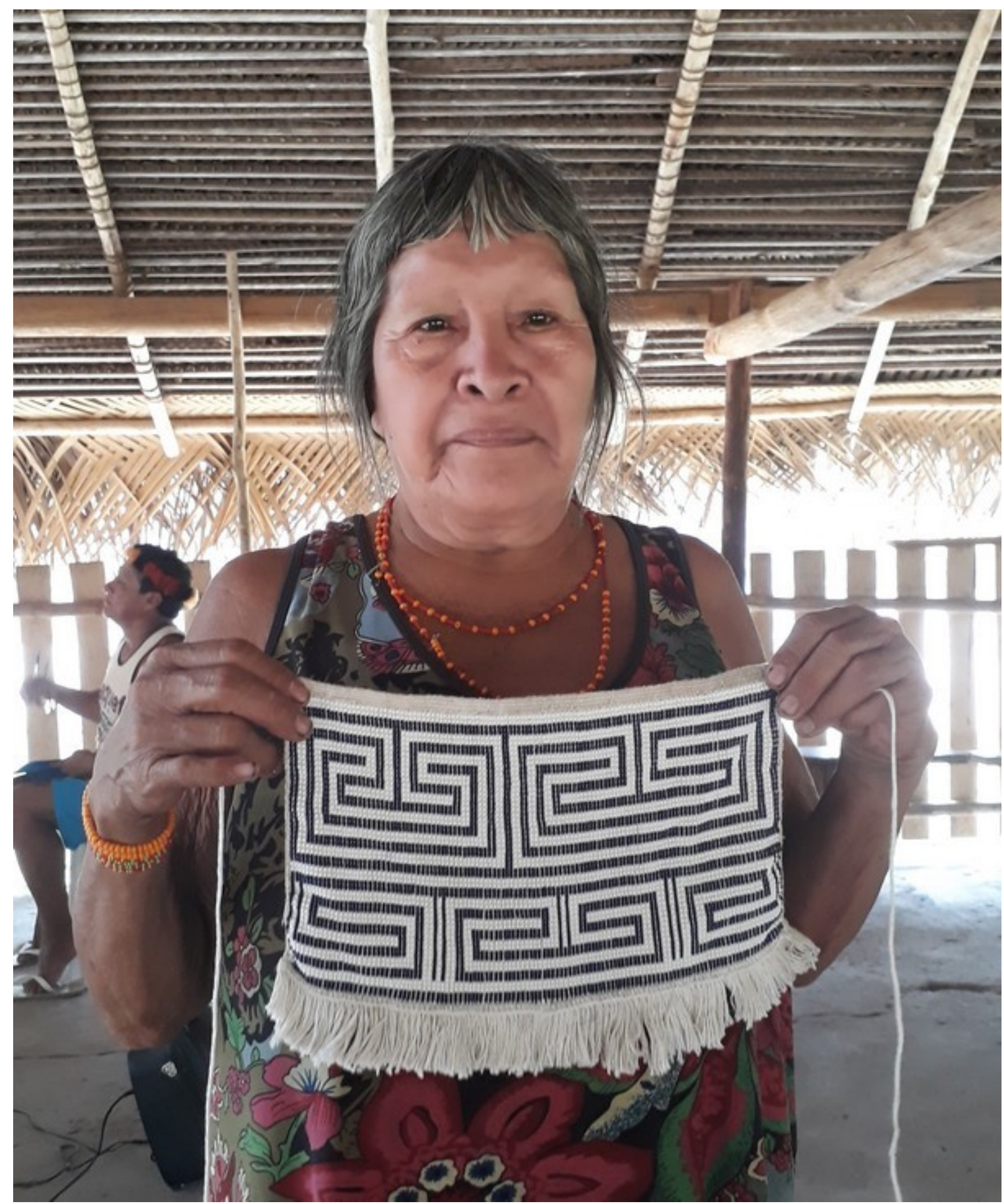

Figura 34: Salomé Takëfë Tiriyó nos mostra keweyu feito por ela com o padrão kaikui ipana (orelha de onça). Abril de 2019. 


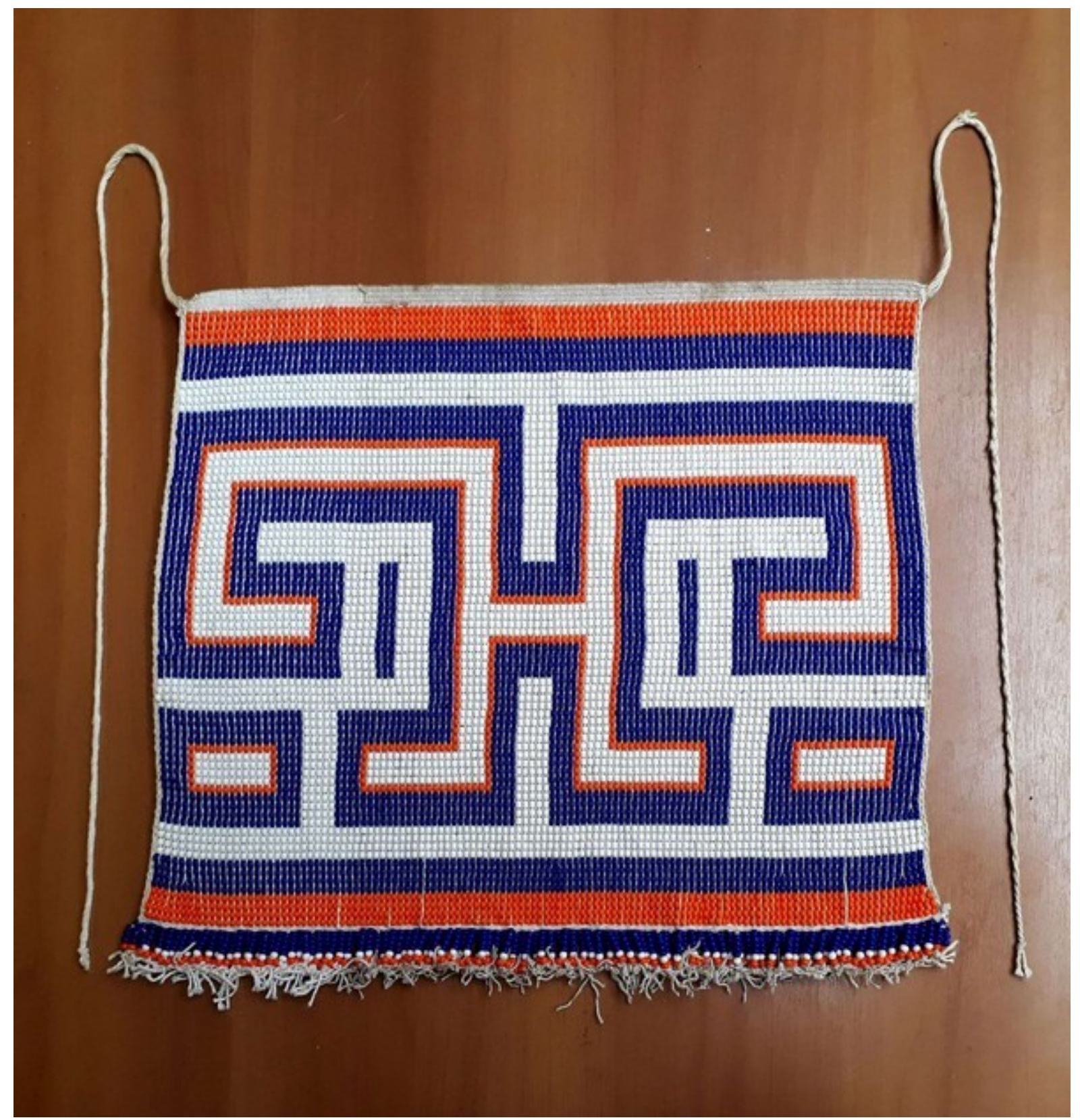

Figura 35: Weju feito por Xipatai Apalai, com grafismo kaikuxi (onça sobrenatural). 2019. 
Já cintos, pulseiras e brincos não possuem repertório fechado. Nas peças encontradas no Museu Paraense Emilio Goeldi, feitas entre as décadas de 1960 e 1970, os motivos tecidos seguem os padrões e composições das pinturas corporais (Fig. 36).

Hoje em dia, porém, não parece possível circunscrever os motivos que aparecem nesses adornos, sendo as pulseiras aquelas que apresentam maior variabilidade nos motivos utilizados: tanto padrões utilizados tradicionalmente nas pinturas corporais e de cestaria, quanto os mais apreciados hoje em dia, como corações, palavras (o próprio nome, o nome de alguém da família, Jesus, nomes de times de futebol, a palavra love) (Figs. 37 e 38), ou padrões que imitam lagartas do tipo taturana (tão recorrentes nas mitologias locais).

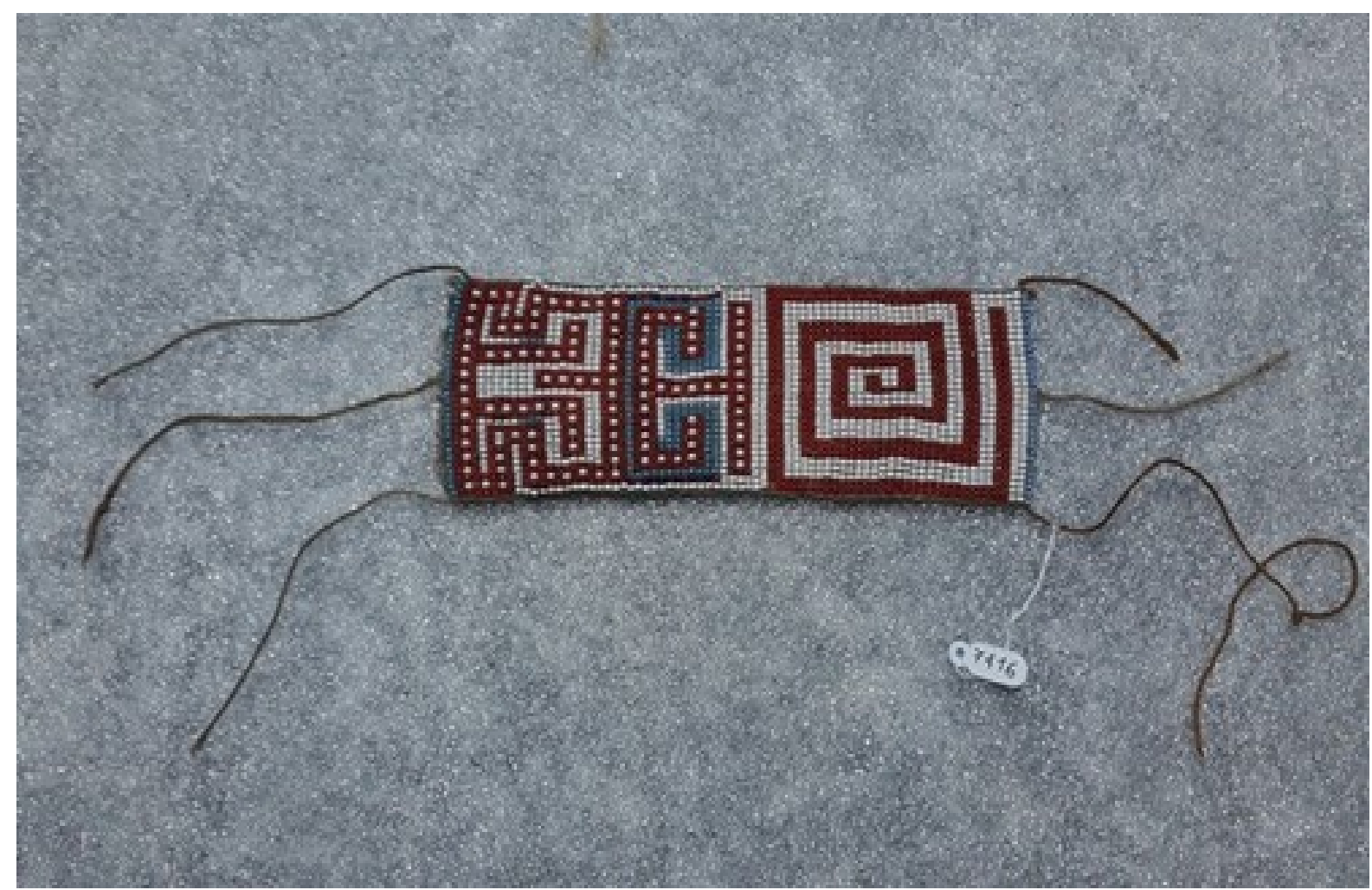

Figura 36: Pulseira tiriyó, localizada no Museu Paranense Emilio Goeldi, sob a identificação 7416. 


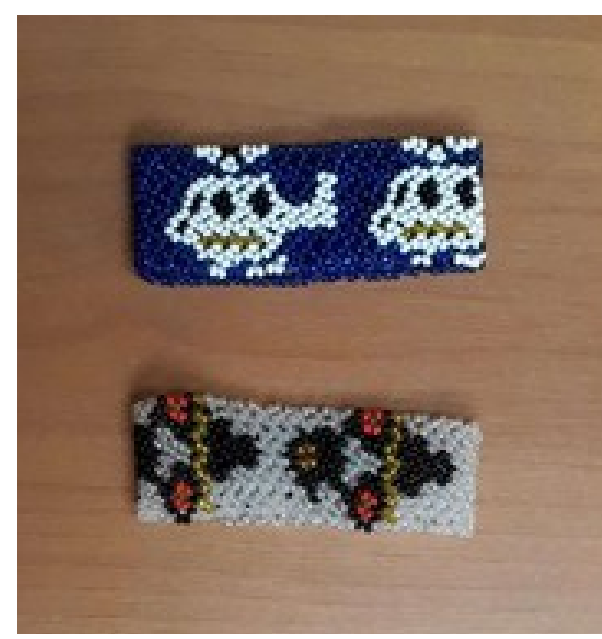

Figura 37: Pulseiras de miçangas por Lorena Ikunau Tiriyó, com imagens figurativas de helicóptero $e$ papagaio. (2017)

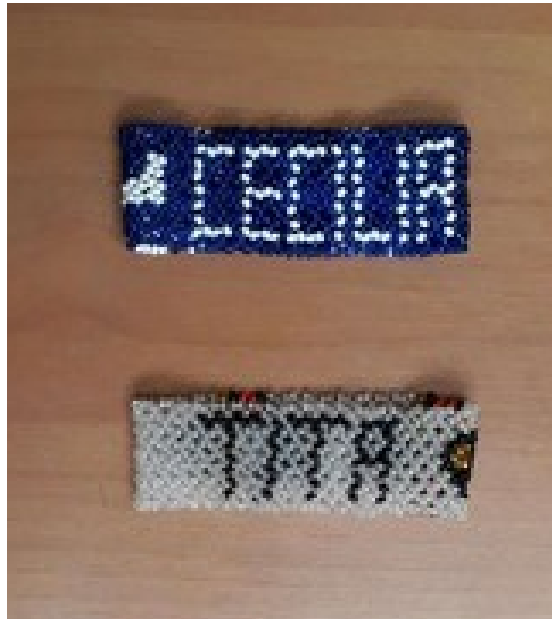

Figura 38: Verso das pulseiras apresentadas na figura anterior, contendo meu nome e meu apelido.

Nos cintos panti (fig.38), por excelência de uso masculino em ocasiões festivas e de reuniões, vemos os padrões tradicionais das pinturas corporais apenas como detalhes, em meio a grandes composições de motivos ligados ao repertório ikuhtu (tiriyó) ou pampiram imilikut/ pampiram menuru. Essas imagens tiradas principalmente dos livros de ponto-cruz trazidos por missionários norte-americanos trazem figuras como leões, pássaros, helicópteros, padrões utilizados por indígenas norte-americanos, e mesmo cenas como a ordenha de vacas.

A partir do exposto, é possível evidenciar outra característica comum na constituição dos repertórios iconográficos na região: a imitação é um procedimento central em seus usos. É por meio da imitação que se 'pegam' os desenhos dos outros, sejam eles Anacondas sobrenaturais ou mesmo imagens puxadas da internet que circulam pelos celulares nas aldeias, por meio do aplicativo ShareIt. Ao transportar comigo o catálogo da exposição No Caminho das Miçangas (Lagrou 2016), muitas foram as imagens tiradas dele para a reprodução de novas peças.

Como já nos indicava Tarde (2007), é inerente à cópia o germe da mudança. Não há cópia perfeita, pois tudo está sujeito às diferenças infinitesimais. As imitações promovidas pelas mulheres tiriyó, katxuyana e txikiyana, ao copiarem modelos e desenhos dos mais variados suportes também apontam nessa direção. Alteram-se cores e detalhes, e, nessas diferenças infinitesimais, essas mulheres apropriam-se de materiais, desenhos e mesmo técnicas estrangeiras, produzindo (novos) corpos, a partir de suas habilidades e criatividade, tecendo relações dentro e fora de suas aldeias. 


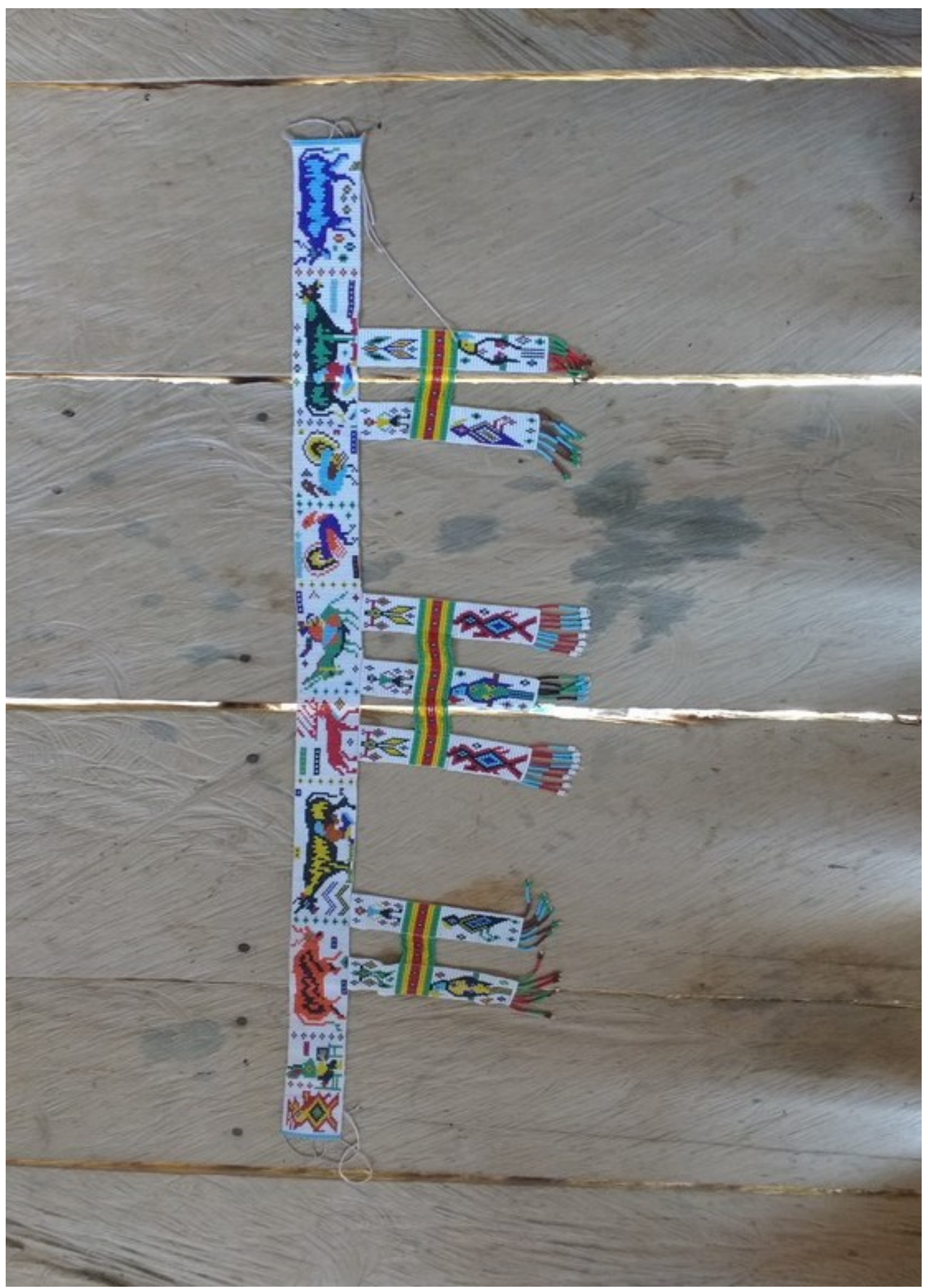

Figura 39: Panti tecido por Julieta Tatari Kaxuyana Tiriyó. Aldeia Santo Antônio, 2017. 


\section{Casulos e tullmas}

A rápida apropriação que acontece envolvendo adornos de miçangas pode ser acompanhada no episódio que vivi entre os anos de 2015 e 2017, junto às mulheres tiriyó e katxuyana da aldeia Santo Antônio, lado oeste da TI Parque do Tumucumaque. Em 2015, quando lá estive por ocasião do acompanhamento de atividades ligadas ao Iepé, levei comigo duas tullmas, enfeite de cabelo muito utilizado pelas mulheres bolivianas. Trata-se de uma corda de lã, com cerca de 50 a $60 \mathrm{~cm}$, cujas pontas são bifurcadas e recobertas com miçangas, exibindo diversas argolas também em miçangas. As bolivianas usam as tullmas trançadas em seus cabelos. Um dos exemplares era original, trazido por mim de uma viagem ao Salar do Uyuni, e o outro, uma tentativa de reprodução deste enfeite feita por mim mesma (não muito bem-sucedida).

Como era de se esperar, as mulheres ficaram encantadas com as tullmas, logo as adaptando às suas preferências: de enfeite para cabelo, a tullma transformou-se em colar, e, me disseram elas, seria feita agora nas cores vermelho, preto e branco (a original era verde, e a feita por mim, laranja). Disseram-me também que todas iriam querer ter um colar como aquele, querendo saber de onde veio, e que a tradução de seu nome em língua portuguesa remetia à palavra casulo. Pediram, então, que eu deixasse com elas o exemplar original, e me falaram que aquele que eu havia tentado fazer não estava bem feito, pois eu não utilizara a linha adequada: para que as argolas ficassem armadas, era preciso utilizar linha de pesca. Asseguraram-me que não perderiam minha tullma, e que assim que eu voltasse para lá, elas me dariam um colar daqueles.

O modo praticamente instantâneo com que o adorno boliviano se tornou um colar tiriyó, com nome, cores e maneiras adequadas de fabricá-lo e utilizá-lo também chama atenção, especialmente pelo nome recebido, ligado à transformação das larvas (tão esteticamente - portanto também moralmente - apreciadas pelos povos da região) em borboletas. O desprezo pelo adorno por mim confeccionado também é interessante, afinal eu não soubera imitar de modo satisfatório a versão original. No caso, o principal ponto das mulheres é que eu não havia utilizado o tipo de fio adequado (utilizei linha de costura ao invés de linha de pesca, o que não conferia o mesmo caimento às argolas). 
Em 2017, pude retornar à aldeia Santo Antônio, acompanhando outra atividade, desta vez ligada à implementação do Plano de Gestão Territorial e Ambiental da região. As mulheres de lá ficaram muito contentes em poder me devolver tanto minha peça original, quanto finalmente me presentear com as reproduções que haviam feito, utilizando diversas cores, tantos de miçangas quanto na parte dos fios. $\mathrm{O}$ uso como colar foi mantido. Segundo elas, em alguma festa que aconteceu na aldeia acima, Pedra da Onça, elas foram usando seus novos colares, o que provocou muita admiração nas mulheres da outra aldeia.

\section{Fabricando corpos de miçangas}

Hoje em dia, apesar das meninas pequenas já começarem a aprender a enfiar miçangas em fios, tão logo já passando a tecer pulseiras com agulhas (samura tïkapïfë tëgen akusa), não são muitas as mulheres que sabem tecer keweyu, monenoho ou weju. Todas as mulheres mais velhas dominam essa técnica, assim como algumas mulheres na faixa dos 40 ou 50 anos; não conheci nenhuma moça capaz de tecer um keweyu. Há quem diga que isso acontece porque já não há mais tantas miçangas circulando pela região como antigamente. Outras pessoas, porém, indicam ser a mesma motivação que assola os jovens de modo geral: elas não têm interesse em aprender. Os jovens, por sua vez, tendem a dizer que são as pessoas mais velhas que já não querem ensinar. De todo modo, vemos que há uma quebra nos modos tradicionais de ensino e aprendizagem.

Ao perguntar para uma mulher mais velha quem a ensinou a tecer keweyu, a resposta tende a ser que não foi ninguém, que ela aprendeu sozinha, olhando sua mãe e suas tias trabalhando na execução de peças desse tipo. O segundo grupo de mulheres, nessa faixa entre 40 e 50 anos, já passou por outro tipo de experiência: embora algumas mulheres tenham aprendido observando suas familiares, diversas delas (como Lurdes Kaxuyana) podem indicar precisamente quem a ensinou essa tecelagem por ter aprendido em oficinas voltadas para esse fim, promovidas por volta do ano de 2009, numa parceria entre Museu do Índio, Iepé e APITIKATXI, visando a constituição de uma coleção etnográfica Tiriyó e Katxuyana neste museu, incluindo a exibição dessas peças na exposição No Caminho da Miçanga. É uma reivindicação da Articulação das Mulheres Indígenas Tiriyó, Katxuyana e Txikiyana, constituída em meados de 2018, a promoção de oficinas de miçangas e costura, estando a tecelagem de keweyu ocupando lugar central nesta demanda ${ }^{30}$.

30 Em julho deste ano, a pedido da APITIKATXI, participei da elaboração de um projeto para a CGEtno/Funai, visando a constituição do Fundo de Artesanato Koritomo, conforme as mulheres da AMITIKATXI 


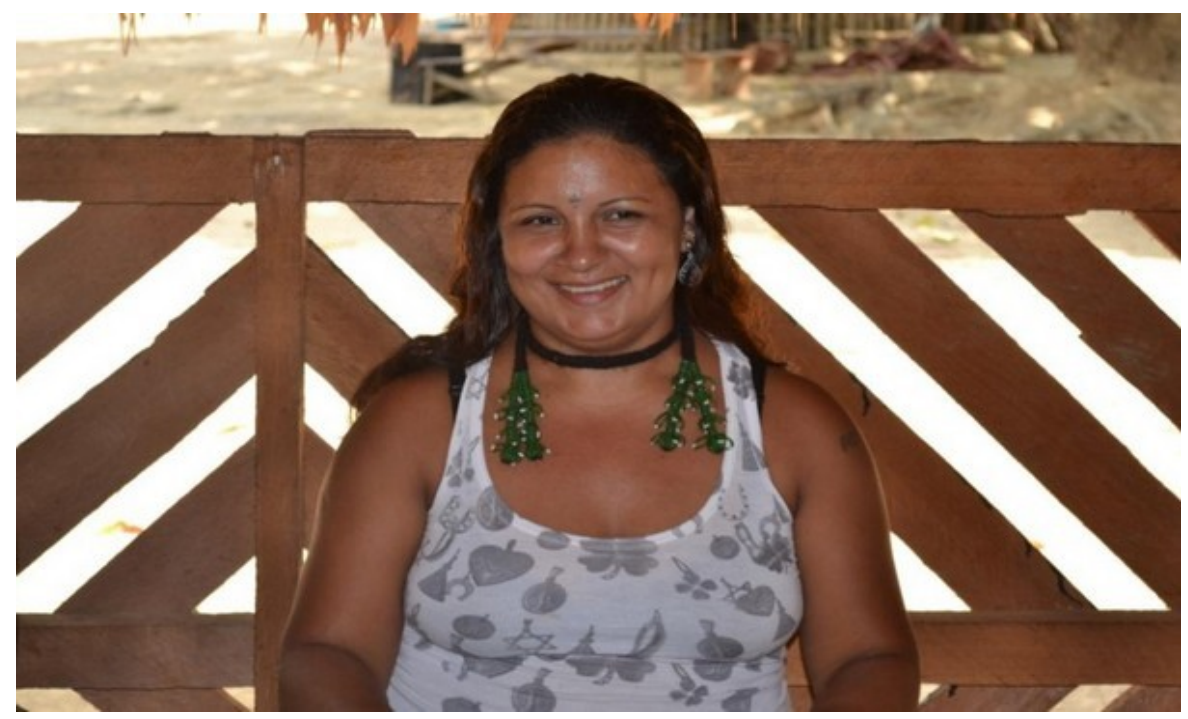

Figura 40: Adriana Tawaya Kaxuyana, mostrando o modo adequado de se usar as tullmas enquanto colar de jakëmi (casulo). Aldeia Santo Antônio, 2015.

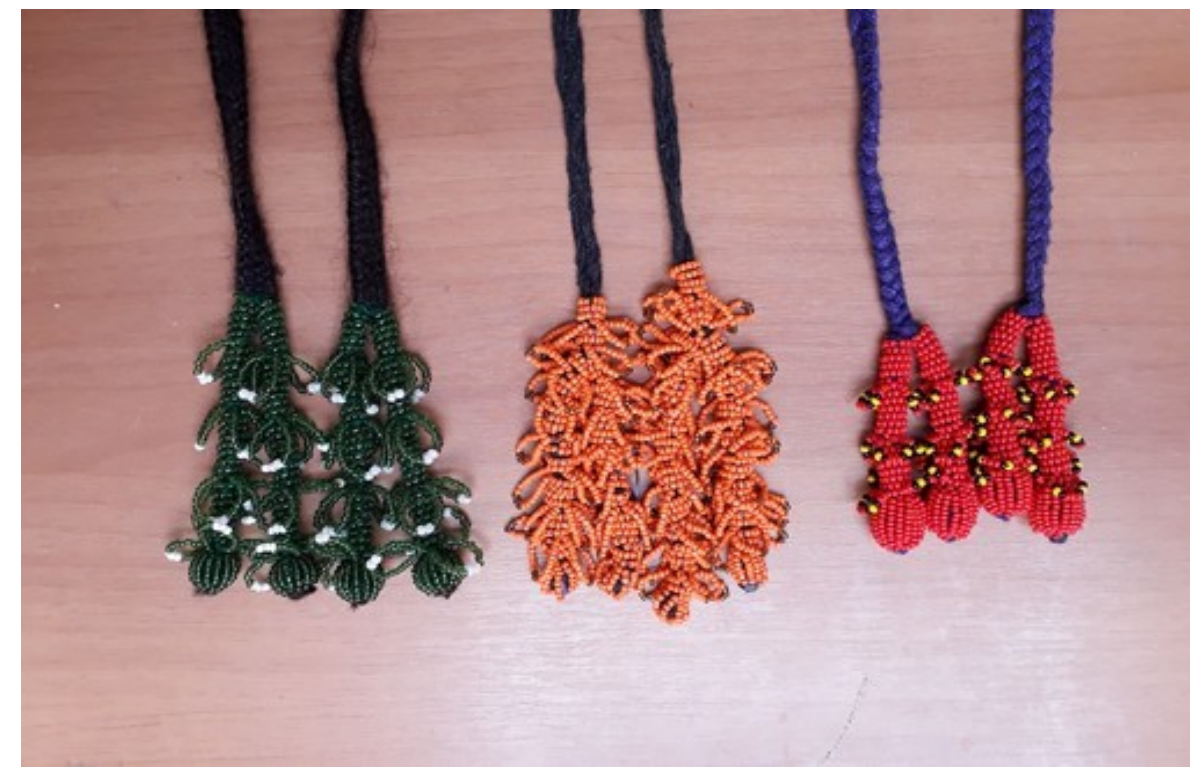

Figura 41: Da esquerda para direita: tullma boliviana original, proveniente do Salar do Uyuni; réplica (problemática) feita por mim; colar jakëmi, feito pelas mulheres da aldeia Santo Antonio, entre 2016 e 2017.

expressaram seu interesse. O projeto foi contemplado em primeiro lugar neste edital, com a primeira oficina prevista para ser realizada em novembro de 2019. Como estarei acompanhando essa atividade enquanto assessora indigenista do Iepé, é provável que a presente pesquisa de mestrado seja apresentada na aldeia, atendendo ao combinado que fiz com as pessoas nas ocasiões em que apresentei meu projeto. 
Durante meu trabalho de campo, em janeiro de 2019, iniciei o aprendizado da tecelagem de keweyu com Lurdes Kaxuyana. As pessoas mostraram-se contentes com meu interesse e também interessadas no que sairia como resultado dos meus esforços. Algumas mulheres mais jovens, próximas a mim, me acompanharam de perto neste processo, participando da tecelagem em alguns momentos, mas não chegando elas mesmas a reivindicar ou providenciar os instrumentos para seu próprio aprendizado. Ainda que as pessoas todas elogiassem o andamento de meu trabalho, quando uma senhora bem mais velha (sogra de Lurdes, uma das mulheres que a ensinou a tecer), deu muita risada dos meus esforços, e me disse que meu keweyu iria ficar parecendo um casco de tatu, tão torto que estava ficando, e que eu deveria tê-la procurado antes, se eu quisesse mesmo aprender a tecer. Ela mesma resolver terminar meu trabalho - é claro que devo admitir que ficou pronto bem mais rápido e com qualidade muito superior àquela que eu poderia executar.

Observação, memorização e repetição aparecem como procedimentos comuns a muitos modos indígenas de se adquirir aprendizados, seja de cantos, seja da produção de artefatos, ou de outras atividades. Yano (2009) destaca, para o caso Huni Kuin (Caxinauá), que a compreensão destes modos de aprendizado não deve se restringir a esses procedimentos, afinal a preparação do corpo é fundamental, tal qual já sinalizavam Seeger, da Mata e Viveiros de Castro (1979).

Entre as mulheres indígenas tiriyó e katxuyana, o momento crucial para o aprendizado das técnicas manuais femininas, como a tecelagem de algodão e de miçangas, dentre outras, acontecia durante a iniciação ritual ao qual as moças púberes eram submetidas na ocasião de sua menarca. Neste momento, elas ficavam reclusas por um longo período, sendo submetidas a finos cortes sobre os quais passava-se uma mistura de pimenta e outras plantas, visando tornar a menina uma moça forte. Os cabelos eram inteiramente cortados. A moça reclusa só recebia a visita de mulheres mais velhas, recebendo pouca e restrita alimentação, como beiju e determinados tipos de peixe, sem nenhuma gordura ou pimenta. Quando de sua saída dessa reclusão (algumas pessoas indicam que a moça saía quando seu cabelo crescesse novamente, outras dizem que é quando ela aprendia todas as atividades necessárias), a moça era abundantemente ornamentada, e muitas vezes já apresentada ao rapaz com o qual deveria se casar. 
Atualmente, o período de reclusão não é mais praticado. Algumas famílias executam os procedimentos de corte de cabelo da menina, bem como o de realizar os finos cortes em sua pele. Do mesmo modo, as atividades que envolvem o preparo dos fios de algodão, a cerâmica, a tecelagem de keweyu, são cada vez menos conhecidas pelas mulheres. Quando refletem a respeito de saberes que não são mais muito praticados hoje em dia, como os trabalhos em cerâmica ou mesmo a tecelagem do algodão e dos keweyu, algumas pessoas indicam que essas mudanças estão relacionadas.

Contudo, não é na retomada desse resguardo outrora praticado (uma de minhas interlocutoras, atualmente com cerca de 35 anos, ainda passou por ele) que os Tiriyó enxergam uma possível revitalização dessas práticas, mas sim em oficinas e projetos, estando atividades com miçangas sempre no topo das reivindicações feitas por elas para sua associação, já tendo inclusive passado por experiências mais ou menos exitosas, como mencionado acima. A principal dificuldade na continuidade dos projetos envolvendo miçangas, segundo as próprias mulheres, é a inveja e o ciúme que acabam aparecendo entre as mulheres envolvidas - o que nos lembra a cautela com a qual as mulheres marubo lidam com o material (Marubo 2016:102).

É sobretudo no final da tarde que as mulheres realizam suas atividades com miçangas, sentadas em suas redes, com suas tigelas de metal ou plástico. Reunindo-se enquanto conversam animadamente sobre os mais diversos assuntos, ou mesmo sozinhas e concentradas, a tecelagem de peças de miçangas têm sua continuidade garantida entre as mulheres desses povos indígenas.

\section{O traje tradicional karib e suas variações}

Conforme já foi apresentado, é durante a década de 1960 que acontece a instalação da Missão Franciscana na região da cabeceira do rio Paru de Oeste. Datam deste período a maior parte das peças pertences ao acervo do Museu Paraense Emílio Goeldi, bem como parte significativa do acervo fotográfico da região. Um dos principais responsáveis pela elaboração de peças e pelo registro etnográfico é Protásio Frikel, alemão que inicia suas atividades na região como missionário católico, depois abandonando a vida religiosa para dedicar-se à pesquisa etnológica junto ao Museu Paraense Emílio Goeldi. Diversos registros fotográficos 
foram feitos por esses missionários de origem alemã, muitos dos quais a antropóloga Denise Fajardo (Grupioni) dispõe de cópias, as quais gentilmente me cedeu ao longo da pesquisa.

Com a possibilidade de organizar e consultar regularmente todo este acervo de ilustrações, pude perceber melhor o conjunto de variações e recorrências no traje tradicional contemporâneo desses povos. Para completar tais variações, pude ainda acrescentar o traje wajãpi, para o qual elaboro rascunho a partir da observação em eventos e fotos. A sistematização dos elementos desses trajes, em sua composição pan-guianense denota, ao mesmo tempo, as redes de relações vigentes na região pelo empréstimo de adornos, que pode ser notado ao longo dos séculos, e a formação de "identidades étnicas" que se tornam necessárias para que se travem relações com o Estado brasileiro, conforme explora Gallois (2017).

A seguir, apresento uma ilustração elaborada por mim do traje tradicional da mulher kahyana (Fig. 42), conforme a senhora Maria Vieira Kahyana me informou. Em seguida, a foto de uma mulher tarëno (fig. 43), provavelmente Aramiso, conforme me indicaram diversas mulheres ao longo da pesquisa de campo; essa foto foi tirada entre o final da década de 1960 e o início da década de 1970. A ilustração (Fig. 44) que acompanha essa foto apenas facilita na identificação dos adornos que ali aparecem. Também há a foto de um homem tarëno (Fig 45), da mesma época, em que se pode apreciar no detalhe (Fig. 46) o vasto uso de miçangas. As ilustrações dos trajes masculino e feminino (Fig. 47 e 48) foram elaboradas por jovens aparai e wayana, sob orientação de mulheres mais velhas desses mesmos povos, em dezembro de 2018, quando apresentei para elas o estado atual da pesquisa. Por fim, uma foto de uma festa wajãpi (Fig 49), evidenciando o quanto a estética da região integra as redes de relações entre esses povos ameríndios - certamente estendendo-se a outros povos, talvez numa intensidade maior no passado, como podemos inferir a partir de Crevaux (1883) e de outros materiais como o filme Dessine-moi... une frontière (2004). 


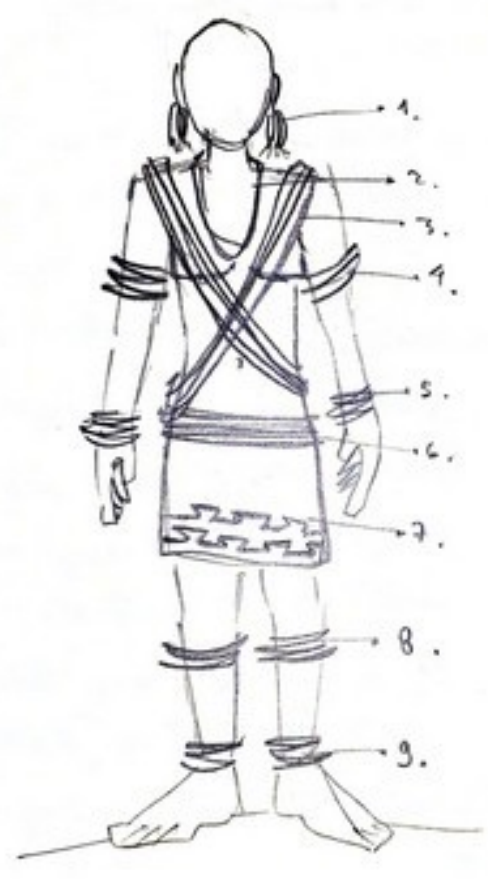

Figura 42: Traje tradicional de mulher kahyana, conforme informado por Maria Vieira Kahyana.

\begin{tabular}{|l|l|l|}
\hline $\begin{array}{l}\text { N. de } \\
\text { identificação }\end{array}$ & $\begin{array}{l}\text { Nome emlíngua } \\
\text { katxuyana/werikiyana }\end{array}$ & Identificação segundo Ribeiro (1988) \\
\hline 1 & panatxere & Adorno auricular de miçangas \\
\hline 2 & wonoto & Colares de voltas \\
\hline 3 & wayakuma & Bandoleiras (miçangas ou algodão) \\
\hline 4 & ahomï & Braçadeiras \\
\hline 5 & omekmatxi & Pulseiras \\
\hline 6 & okonumitxi & Cinto (algodão ou outra fibra vegetal) \\
\hline 7 & monenoho & $\begin{array}{l}\text { Tanga frontal (miçangas e pendentes } \\
\text { variados) }\end{array}$ \\
\hline 8 & warakumitxi & $\begin{array}{l}\text { Jarreteiras (miçangas ou algodão e } \\
\text { sementes) }\end{array}$ \\
\hline 9 & mëtëmitxi & Tornozeleiras \\
\hline
\end{tabular}

Tabela 1: Identificações do traje tradicional kahyana 


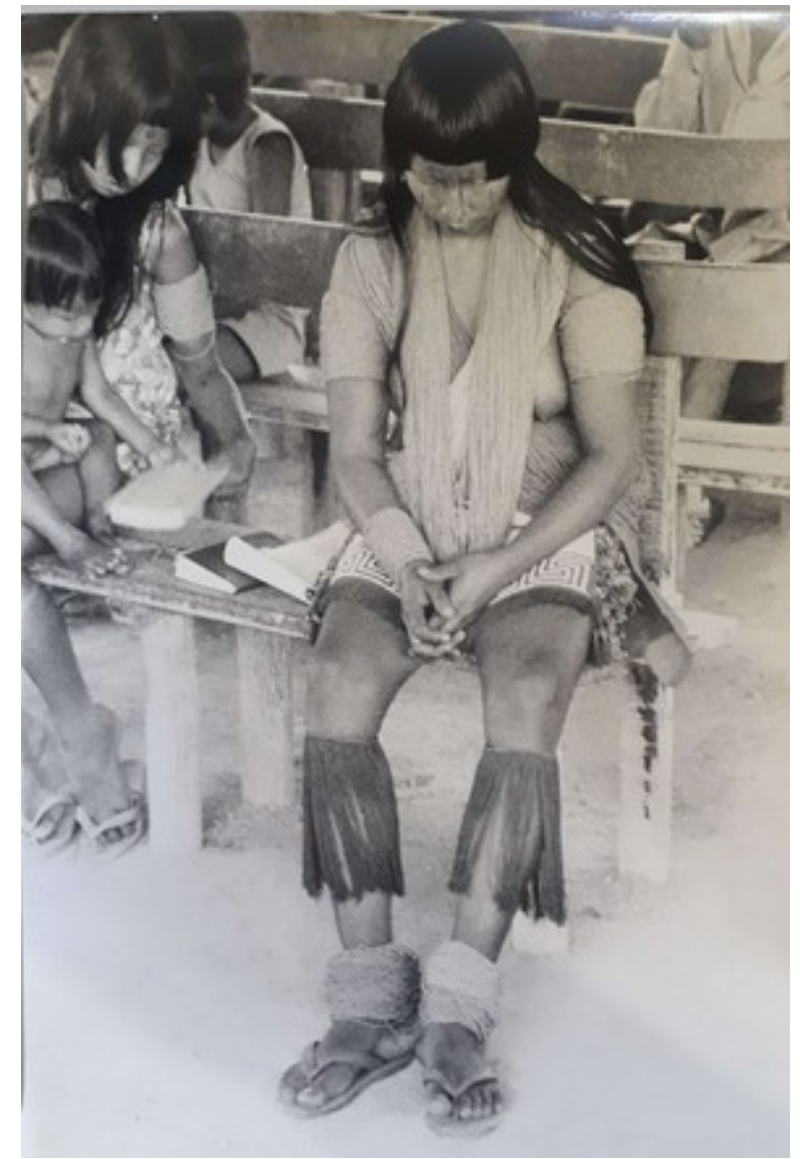

Figura 43: Mulher tarëno (provavelmente Aramiso), participando de uma missa. Final da década 1960/ Início dos anos 1970 Acervo Denise Faiardo

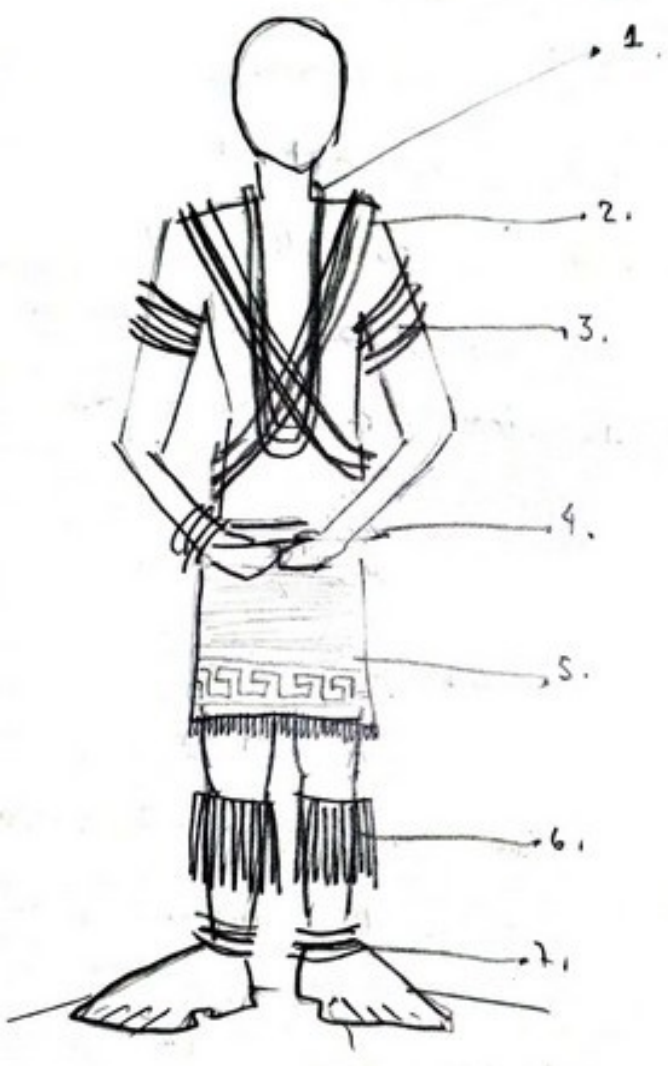

Figura 44: Esquema para identificação do traje tradicional tarëno, conforme tabela abaixo.

\begin{tabular}{|c|c|c|}
\hline $\begin{array}{l}\text { N. de } \\
\text { identificação }\end{array}$ & Nome em língua tiriyó & Identificação segundo Ribeiro (1988) \\
\hline 1 & Aiyi & Colares \\
\hline 2 & Iyafan & Bandoleiras (miçanga ou algodão) \\
\hline 3 & Ëpёiуa & Braçadeira \\
\hline 4 & Ëmena & Pulseira \\
\hline 5 & Keweyu & Tanga \\
\hline 6 & Karuta & Jarreteira (algodão) \\
\hline 7 & Irami & Tornozeleira \\
\hline
\end{tabular}

Tabela 2: Identificações do traje tradicional aramiso (tiriyó) 


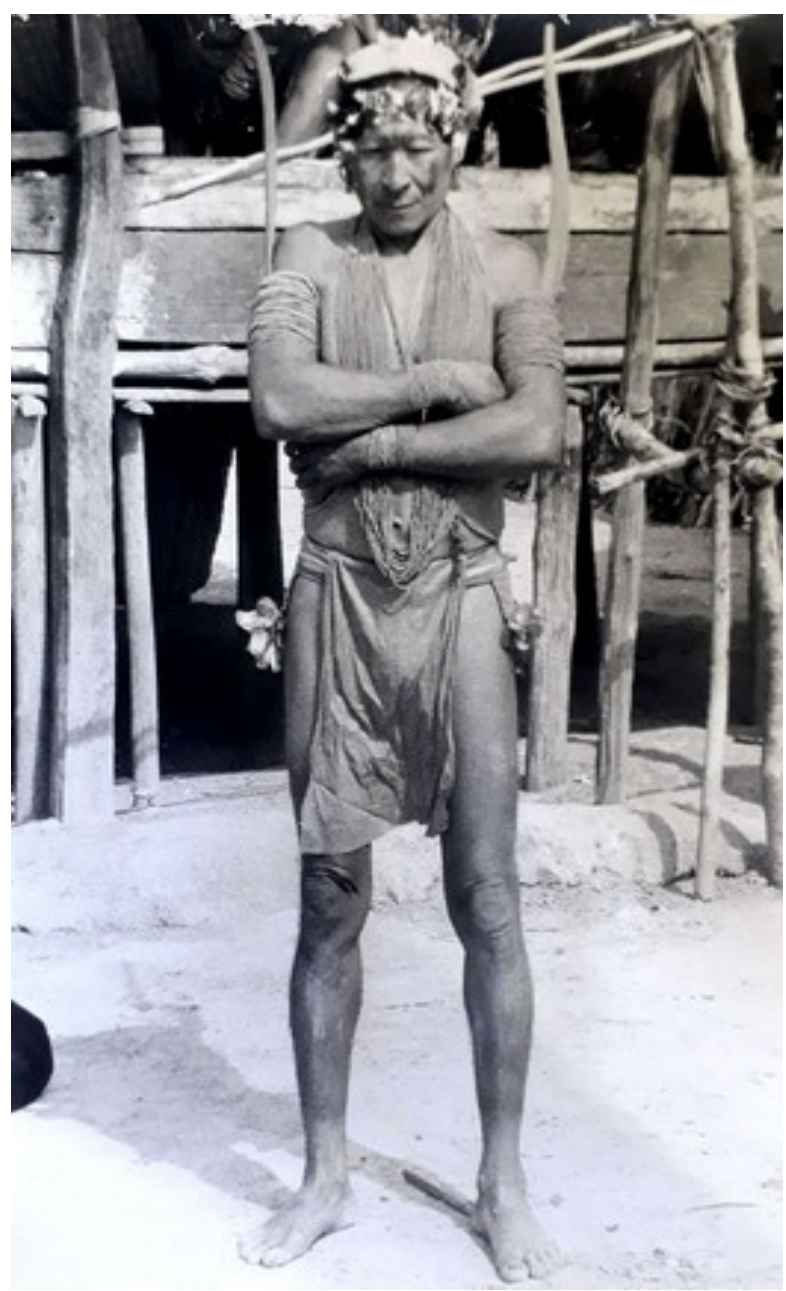

Figura 45: Homem tarëno. Observa-se o uso do adorno de quadril chamado em língua tiriyó okunxoro (Frikel 1973), além de um penacho alçado de braçadeira (cf. Ribeiro 1988), diadema de plumária, plumas no cabelo, e tanga masculina kamisa. Acervo Denise Fajardo.

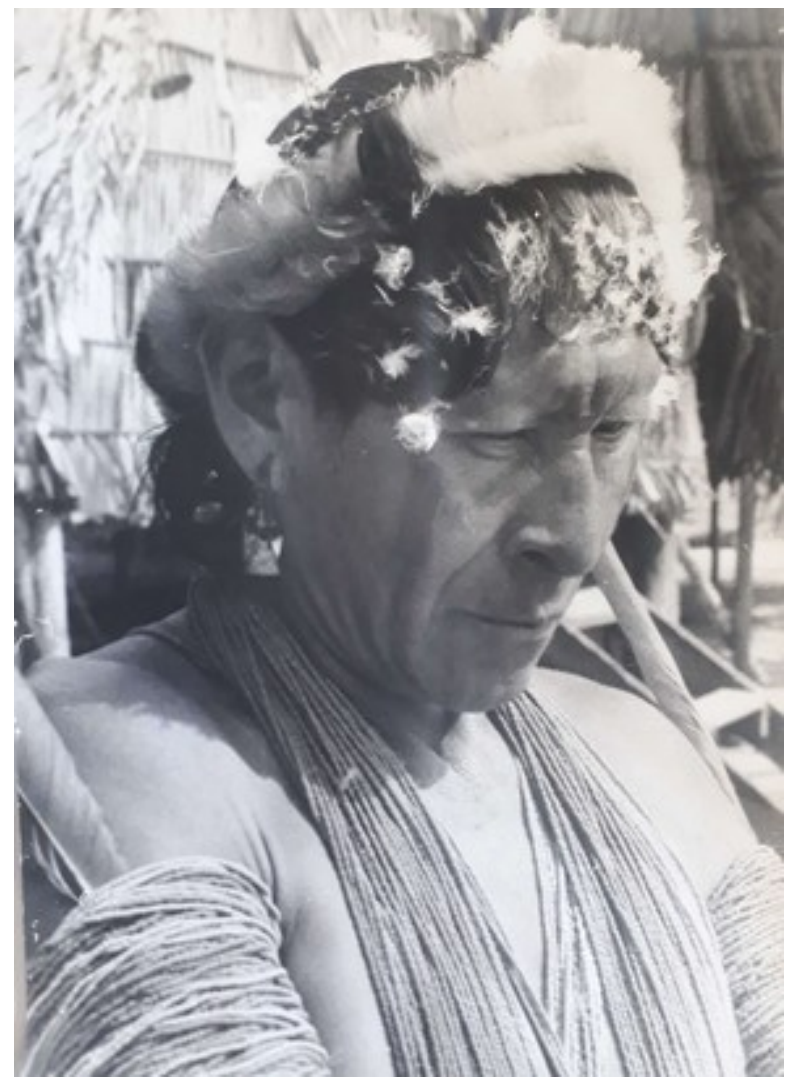

Figura 46: Detalhe da ornamentação do mesmo homem da imagem anteior, destacando a profusão de miçangas. Acervo Denise Fajardo. 

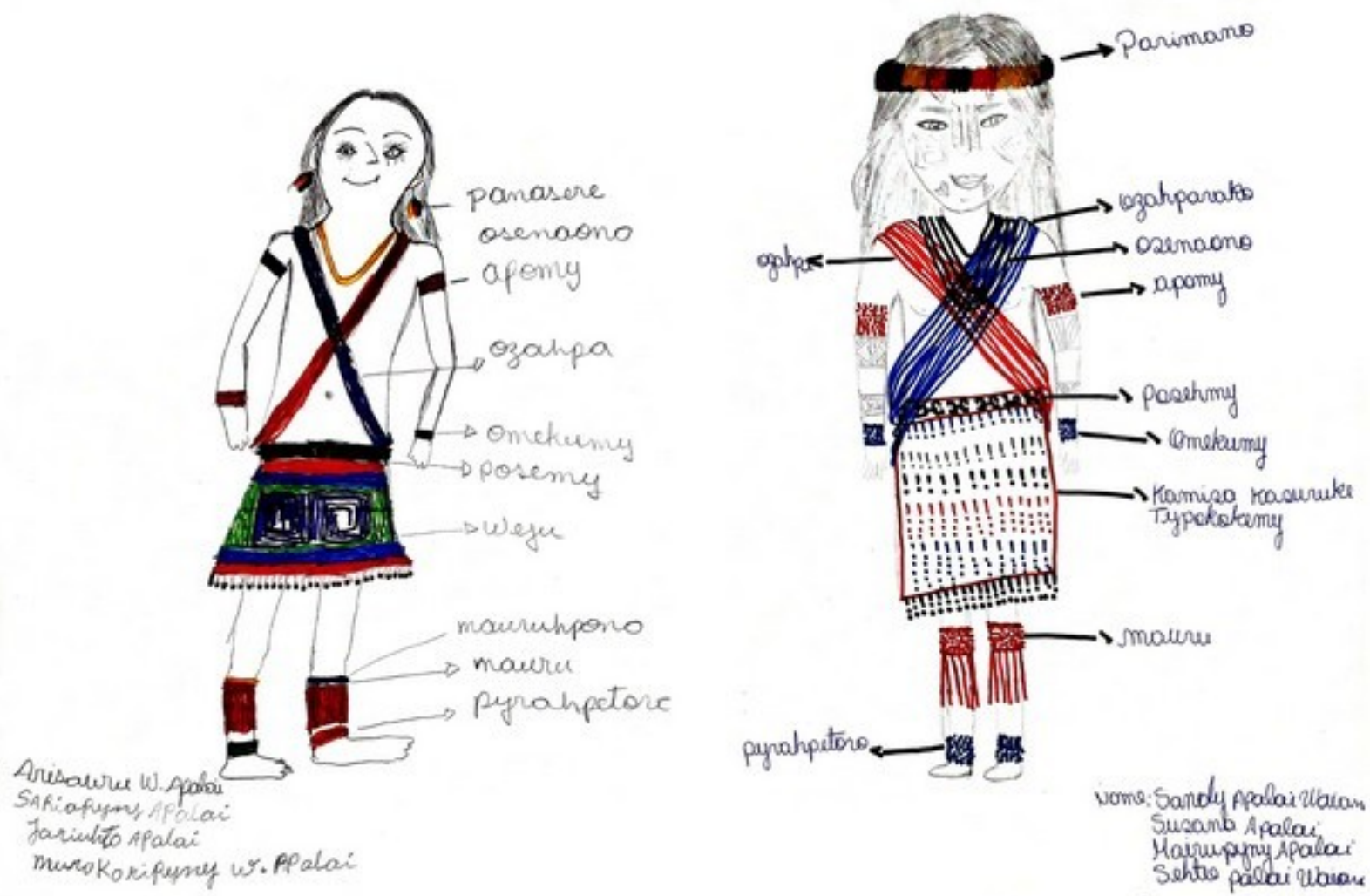

Nome: Sandy palai Ulaiam Sucanb Apalai: Maimpany Apalou Sehtio parai wavers

Figura 47: Ilustrações do traje tradicional feminino aparai, produzidas por mulheres wayana e aparai. Dezembro de 2018.

\begin{tabular}{|l|l|}
\hline Nome em língua aparai & Identificação segundo Ribeiro (1988) \\
\hline Panasere & Adorno auricular de miçangas \\
\hline Osenaono & Colar de voltas \\
\hline Apomy & Braçadeira \\
\hline Ozahpa & Bandoleiras \\
\hline Omekumy & Pulseira \\
\hline Posemy & Cinto \\
\hline Weju & Tanga \\
\hline Mauruhpono & Jarreteira (algodão) \\
\hline Pyrahpetoro & Tornozeleira \\
\hline Parimano & Diadema plumária \\
\hline Kamisa Kasuruke Typokokemy & Saia de tecido, com aplicações de miçangas \\
\hline
\end{tabular}

Tabela 3 Identificações do traje tradicional aparai feminino 


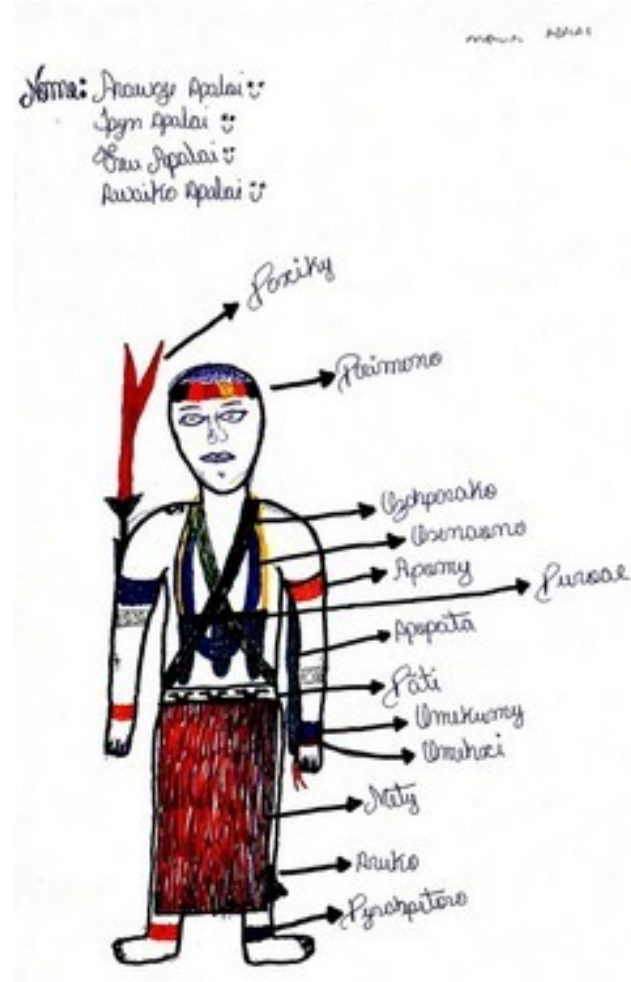

Figura 48: Ilustração do traje tradicional aparai masculino, produzida por mulheres wayana $e$ aparai. Dezembro de 2018.

\begin{tabular}{|l|l|}
\hline Nome em língua aparai & Identificação segundo Ribeiro (1988) \\
\hline Paimono & Adorno auricular de miçangas \\
\hline Paxiky & Penacho alçado de braçadeira \\
\hline Ozohporako & Bandoleira \\
\hline Osenaono & Colar de voltas \\
\hline Apomy & Braçadeira \\
\hline Puroae & Pendente \\
\hline Apopata & Pendente de algodão ligado à braçadeira \\
\hline Pãti & Cinto \\
\hline Omekumy & Pulseira \\
\hline Omehxi & Pendente de pulseira \\
\hline Mety & Tanga \\
\hline Aruko & Jarreteira (algodão) com sementes \\
\hline Pyrahpetoro & Tornozeleira \\
\hline
\end{tabular}

Tabela 4: Identificação traje tradicional aparai masculino 


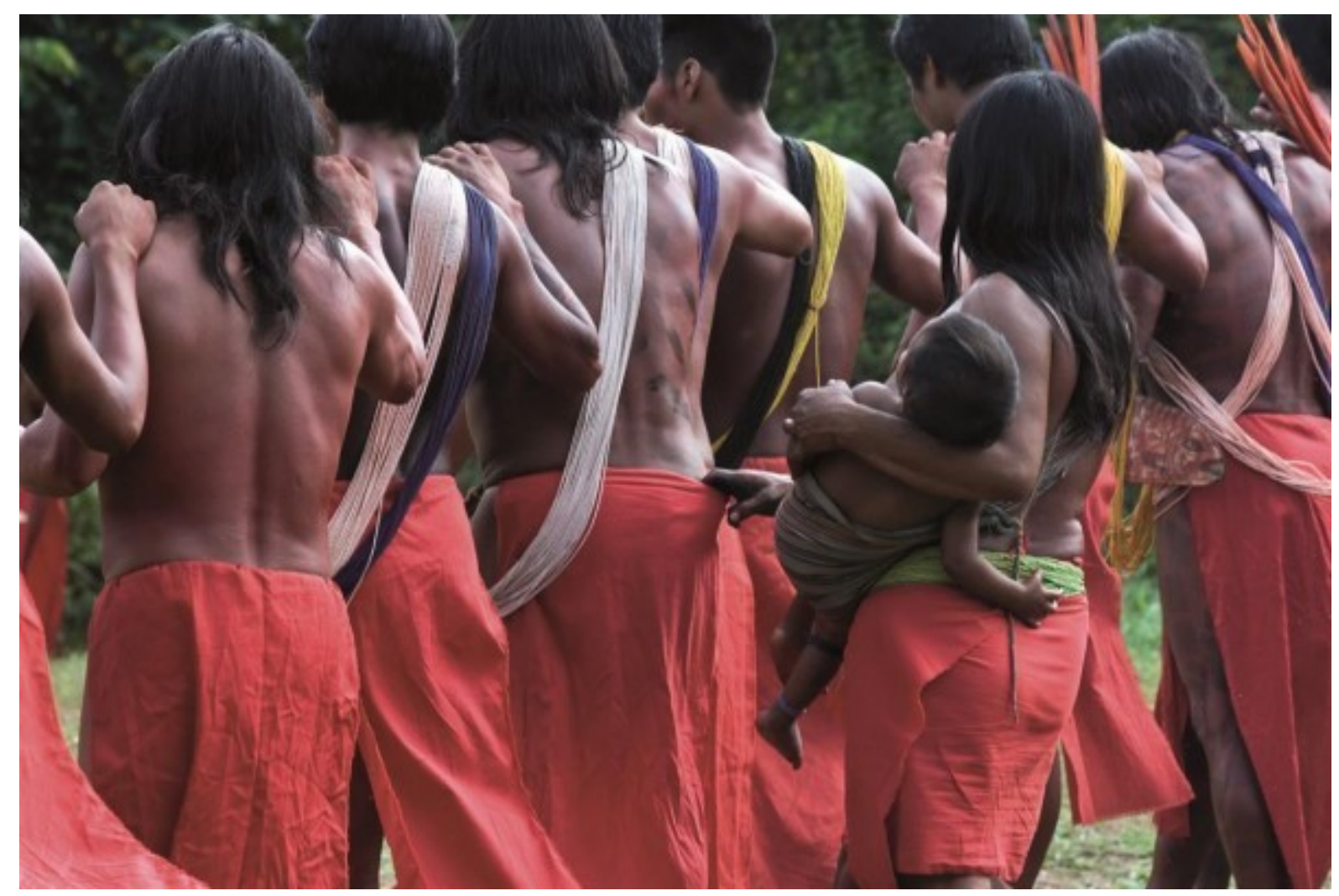

Figura 49: Homens e mulher wajãpi dançam durante a Festa do Pacu. Foto: Mário Vilella. Disponível em: https://www.institutoiepe.org.br/programas/programa-wajapi/ [Acesso em 07 de outubro de 2019]

\section{Na Festa Kahyana}

A situação que narro a seguir traz, mais uma vez, um exemplo de como a etnificação aparece no cotidiano dos povos indígenas karib guianenses, assim como mencionado ao final do capítulo 1 e na subseção acima, intitulada "Controvérsias na patrimonialização de saberes em rede". Desta vez, trata-se de um embate em torno da veracidade do que seria o traje tradicional adequado a ser utilizado durante a Festa Kahyana: uma grande celebração promovida pela AIKATUK - Associação dos Povos Indígenas Katxuyana, Tunayana e Kahyana, e apoiada pelo Iepé, em resposta às acusações feitas a esses povos de que os Kahyana não mais existiriam, mobilizando até mesmo um artigo de Protásio Frikel para isso (1966). Essa festa aconteceu em maio de 2018, na aldeia Kaspakuru, às margens do Rio Trombetas. 
O contexto dessa disputa é a regularização da Terra Indígena Kaxuyana-Tunayana, iniciada em 2003, e que atualmente se encontra em processo de demarcação física (Iepé \& CPI-SP, 2013:3). O mencionado artigo de Frikel também traz elementos da história que levou os Katxuyana e os Kahyana (mas também os Ewarhoyana, Tunayana, Txikiyana, dentre outros) a serem deslocados para longe do rio Trombetas e seus afluentes, como o rio Cachorro (Katxuru) e o rio Turuni.

Frikel destaca as guerras entre os diferentes yana como grande motivação para o deslocamento e depopulação desses povos. De fato, vemos que essas guerras possuem local central no modo como esses povos indígenas contam suas histórias, seja aquelas que remontam a seus corpos míticos, seja para justificar o momento de reunião em torno das missões cristãs que se instalaram por toda a região (Gallois, 1983; Grupioni \& Andrade orgs. 2015).

É claro que esta não é a única razão para tamanha mobilização, conforme as fontes acima citadas também apresentam. Essa região é rica em minérios, e logo em seguida ao deslocamento desses povos indígenas, tanto para a região da Missão Tiriyó, quanto para região de Kwamala (Suriname) ou de Kassawa (rio Nhamundá), observa-se o início de obras para a construção de um pólo de extração de bauxita, de uma hidrelétrica e de estradas (BR 210 e ramais). Essas obras retornam à pauta dos dias de hoje, com o Projeto Barão do Rio Branco, proposto pelo governo federal.

Conforme ocorre o deslocamento desses povos indígenas para essas outras regiões, outro movimento de migração se intensifica na região: as comunidades quilombolas que vivem na região do baixo rio Trombetas, com quem esses povos indígenas já mantinham diversas relações, incluindo matrimoniais, passam a avançar na ocupação dessas regiões mais acima do rio. Soma-se às populações quilombolas, trabalhadores engajados nas obras acima mencionadas.

Outra movimentação que acontece na região, marcadamente na primeira década dos anos 2000, é declaração de unidades de conservação, como a Floresta Estadual do Trombetas (FLOTA Trombetas), cujo decreto foi assinado em 2006. A área de abrangência dessa FLOTA, segundo seu decreto, abarcaria toda a região do rio Trombetas e seus afluentes de ocupação tradicional Katxuyana, Tunayana e Kahyana. Embora a legislação das Florestas Estaduais preveja a admissibilidade da presença de populações tradicionais em seu território, os direitos sobre o mesmo não são os mesmos garantidos quando se trata de Terra Indígena. 
Assim, quando ocorre a intensificação do retorno dos Katxuyana, Kahyana, Tunayana e Txikiyana para a região dos rios Trombetas, Cachorro e Turuni, o cenário territorial já é bem distinto do momento de seus deslocamentos, cerca de 50 anos antes. As diferentes sobreposições entre áreas indígenas, quilombolas e de gestão estadual trazem complicações para o processo de demarcação da Terra Indígena Kaxuyana-Tunayana, que se iniciou em 2008, e até hoje não está concluído ${ }^{31}$. É neste contexto que os povos indígenas da região decidem promover a Festa Kahyana, para celebrar seus modos de vida e sua ocupação de seu território, reivindicando seus direitos sobre ele.

Anualmente, motivadas por este contexto, acontecem as chamadas Assembleias Karib, sempre em alguma aldeia da TI Katxuyana-Tunayana, marcando politicamente a presença indígena na região, sempre com o foco de pressionar o Estado em concluir o processo de regularização fundiária da terra em questão. No ano de 2018, a Assembleia Karib aconteceu na aldeia Mapium, rio Mapuera, reunindo 25 povos indígenas, além de representantes do MPF, da Funai, ICMBio, Ideflor-Bio e de outras instituições parceiras, como o Iepé ${ }^{32}$.

Essa Assembleia Karib foi histórica pela presença de uma delegação de pessoas vindas da TI Parque do Tumucumaque especialmente para o evento. Nessa delegação, havia importantes chefes tiriyó, mas também alguns Katxuyana, Kahyana e Txikiyana que haviam sido retirados da região ainda jovens ou crianças, e que retornavam pela primeira vez para lá, agora alguns deles já trazendo seus netos.

A Assembleia Karib também foi importante para decisões logísticas da Festa Kahyana que aconteceria no mês seguinte. Dentre essas decisões, houve a solicitação para o Iepé de diversos quilos de miçangas para a produção de bandoleiras, bem como de muitos metros de pano vermelho, para uso como tanga masculina e saia feminina. Eu mesma fui uma das assessoras do Iepé designada para a produção da atividade, tanto no que tocava à aquisição das miçangas quanto do acompanhamento da festa em si, fazendo registro audiovisual ${ }^{33}$ da

31 Atualmente, essa terra indígena encontra-se em processo de demarcação física, para só então poder ser homologada pela Presidência da República - situação praticamente improvável na situação política atual.

32 Notícias dessas assembleias podem ser conferidas nos seguintes links: http://www.mpf.mp.br/pa/sala-deimprensa/noticias-pa/assembleia-reune-representantes-de-25-etnias-indigenas-karib-da-calha-norteamazonica [Acesso em 07 de outubro de 2019] e https://www.institutoiepe.org.br/2016/08/iii-assembleiageral-dos-povos-karib-da-ti-katxuyana-tunayananorte-do-para/ [Acesso em 07 de outubro de 2019], dentre outros.

33 Uma reportagem sobre a Festa Kahyana, escrita por Marina Rabelo, para o site do Iepé: https://medium.com/ @.Iepe/uma-festa-kahyana-\%C3\%A0s-margens-do-rio-kahu-70e8327dbf7 [Acesso em 07 de outubro de 2019]. A produção de um filme sobre esta festa está no horizonte de atividades do Iepé. 
festa e orientando jovens vindos da TI Parque do Tumucumaque nos seus próprios registros, enquanto participantes da Formação de Jovens e Lideranças promovida pelo Iepé na região.

Esse preâmbulo visa situar a cena mencionada acima do "desconforto étnico" que as relações com o Estado e a sociedade nacional acabam por criar. Acompanhando algumas lideranças na entrega do tecido vermelho para o preparo das tangas e saias, fomos até a aldeia Araçá, vizinha à aldeia Kaspakuru, onde fomos recebidos com a recusa de seu cacique em utilizar a tanga vermelha, para surpresa geral, visto essa ser reconhecida regionalmente como parte fundamental do traje tradicional.

Para basear sua recusa, o cacique buscou em sua casa uma pasta que continha alguns documentos. De dentro dela, tirou um exemplar do Protocolo de Consulta e Consentimento dos Wajãpi $^{34}$ (2014) e uma página da dissertação de mestrado de Victor Alcântara e Silva (2016:68), que trazia uma foto de Frikel (1966). Alegava o cacique ser um absurdo o uso de tanga vermelha pelos Kahyana, afinal aquela tanga era de uso dos Wajãpi (ele indicava o livro, cuja capa apresenta alguns Wajãpi sentados em frente a uma casa) e não dos Kahyana, como se via pela foto de Frikel, que trazia um homem Kahyana vestido com uma tanga de algodão cru, num modelo diferente daquele utilizado atualmente.

A preocupação do cacique em questão era que o Estado continuaria a não reconhecer os Kahyana enquanto tal, afinal não estariam vestidos conforme a documentação histórica disponível, e sim como os Wajãpi. Seu posicionamento era tão extremo que alegou preferir utilizar uma tanga feita de saca de farinha do que a "roupa wajãpi", mas foi dissuadido por seus parentes, comparecendo à festa com a tanga vermelha, assim como todas as outras pessoas.

Após esse mergulho em aspectos mais técnicos envolvendo a tecelagem de peças feitas de miçangas, podemos retornar ao pote de Lurdes Kaxuyana, com bandoleiras iyafan, pedaços de cintos panti e contas ainda soltas, em meio a variadas agulhas e linhas. Ao lado de sua rede, a armação de um keweyu ainda não terminado está engatada num dos esteios da casa, ao passo que uma pequena saia vermelha, com pendentes de miçangas já desfeitos jaz presa numa das fileiras de palha do teto. A tecelagem de todas essas peças estão sob o encargo de Lurdes, esposa de um dos principais caciques da região e mãe do presidente da associação e dos dois professores de maior destaque. Pessoas, portanto, que frequentemente devem promover

34 Disponível em: https://acervo.socioambiental.org/sites/default/files/documents/WAL00006.pdf [Acesso em 13 de outubro de 2019). 
bebedeiras de sakura e participar de eventos e reuniões. É disso que trataremos no próximo capítulo: os modos como os adornos corporais aparecem em situações políticas, isto é, em festas e guerras.

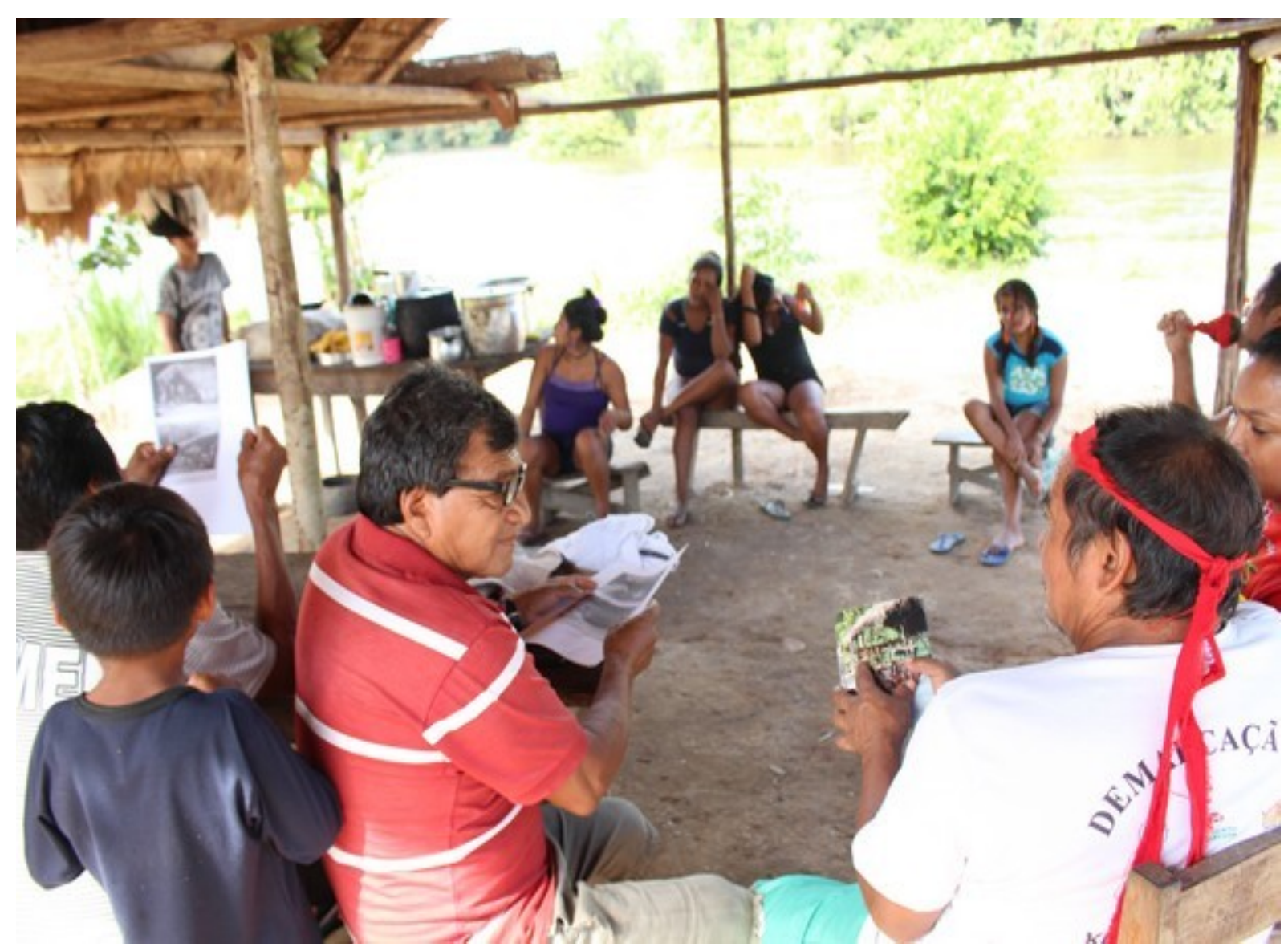

Figura 50: Mário Kaxuyana (à esquerda) observa fotos dos antigos Kahyana, enquanto Kanahtxe (de vermelho) argumenta para Juventino e Angela Kaxuyana (à direita) que o traje vermelho seria tradicional dos Wajãpi e não dos Kahyana, conforme mostra a capa do Protocolo de Consulta e Consentimento dos Wajãpis, que está na mão de Juventino. Aldeia Araçá. Junho de 2018. 
Capítulo 3. Corpos políticos em ações: miçangas e algodão entre festas e guerras 
Que o trabalho de campo seja fator crucial na empreitada antropológica não é nenhuma novidade - é mesmo o pressuposto essencial para essa nossa atividade. A surpresa é não sabermos quais serão os momentos que serão importantes chaves no momento de organizarmos os dados e as leituras acumuladas para a apresentação das ideias elaboradas ao longo do prazo da pesquisa sendo empreendida. O caso que aqui relatarei procura demonstrar como relacionam-se chefia e generosidade entre os Tarëno, denominação em língua tiriyó que, literalmente, pode ser traduzida como "os daqui”, referindo-se a não apenas os Tiriyó, como também a diversas outras gentes que compartilham a região a calha do rio Paru de Oeste como seu local de habitação (Grupioni 2002, 2009).

Final de janeiro de 2019: chego na aldeia Missão Tiriyó, principal aldeia da região, concentrando cerca de metade da população desta porção da TI Parque do Tumucumaque. Após negociações com a APITIKATXI e o Iepé, pude empreender um pequeno trabalho de campo praticamente exclusivo para essa dissertação de mestrado. Com prazo e recursos bem escassos, meu planejamento pragmático contava com a minha estadia na região bastando-se à aldeia Missão Tiriyó, onde procuraria conversar com apenas uma ou outra pessoa mais velha, afinal não havia conseguido levar tantas miçangas quando gostaria para poder presentear as pessoas que pudessem colaborar comigo em minha pesquisa.

Para minha surpresa, ao chegar na aldeia, já havia uma extensa programação elaborada para a minha visita. Lurdes Kaxuyana e Tito Meri Tiriyó, meus anfitriões, já haviam comunicado algumas outras aldeias da região que eu iria visitá-las para conversar com as mulheres sobre miçangas, incluindo a ida a uma caverna chamada por muitos de Tïmenurën 'pintada' - cujas paredes são repletas de desenhos gravados em toda sua extensão. "É importante para teu trabalho conhecer esses desenhos, Tita." - me falaram eles.

Em cada aldeia que passamos pela programação pensada por Lurdes e Tito, uma reunião era feita na casa principal, juntando não apenas o pataentu, mas também todas as pessoas interessadas, em especial as mulheres. Após a apresentação da situação atual de minha pesquisa, as pessoas apresentavam suas concordâncias, bem como recomendações, e uma distribuição de miçangas era feita entre todas as mulheres presentes. Retomarei a questão da distribuição das miçangas adiante, indicando duas diferentes maneiras em que ela acontece.

Assim, apesar de o tempo ser curto e das miçangas serem poucas, Tito e Lurdes evidenciaram o quanto seria inadequado que eu trabalhasse apenas com eles, entre sua 
família, na aldeia central. Ao fazerem questão de me levar em diversas aldeias menores, convocando o maior número de pessoas possíveis, percebi que, deste modo, não apenas as miçangas estavam sendo partilhadas entre um número bem maior de mulheres, mas sim eu mesma estava "sendo distribuída" entre diferentes aldeias. Lurdes e Tito sentiam verdadeiro rechaço pela possibilidade de serem considerados como sovinas pelas demais pessoas.

A generosidade como marca da chefia ameríndia tem sido há muito destacada (Lowie 1948, apud Perrone-Moisés 2011; Lévi-Strauss 1955, Clastres 2003), assim como a importância das trocas e das guerras nas cosmologias desses povos indígenas. O que pretendemos nesse capítulo é descrever como podemos ver as atualizações destas questões nos dias de hoje, a partir dos modos como trocas, guerras, festas e corpos entrelaçam-se entre fios de miçangas e de algodão.

Ao longo deste capítulo, apresentaremos aspectos relacionados à importância da generosidade na chefia tiriyó, bem como a centralidade da preparação corporal nas guerras. Algumas figuras serão também apresentadas, como o pataentu (comumente traduzido por "cacique" ou "chefe") e o püyai ("xamã" ou "pajé"), além das relações pëeto (aliados do pataentu) e pawana (parceiros de trocas). Por fim, destacaremos como as qualidades sensíveis das miçangas e do algodão permitem que pensamos acerca do lugar das festas, das guerras e das relações entre os povos indígenas guianenses.

\section{Chefia e Generosidade}

O casamento entre Lurdes e Tito não obedece ao padrão mais comum verificado nos intercasamentos entre Tiriyó e Katxuyana (Queirós \& Girardi 2012), em que casais compostos por mulher katxuyana e homem tiriyó pouco a pouco têm retornado para os rios Cachorro e Trombetas, de onde foram deslocadas famílias katxuyana, kahyana, ewarhoyana, txikiyana, na década de 1960. Tampouco se trata de uma exceção, como será explicitado a seguir, posto que o local onde se encontra a aldeia Missão Tiriyó há muito tempo ter tido como seu pataentu, homens pïrouyana, ascendentes de Tito Meri.

Visando explicitar como a constituição de uma aldeia por um pataentu, seus ipëriton $\mathrm{e}$ pëetoton nos possibilita entender ética e estética tarëno (dimensão não apartadas), no que tange à generosidade e à abertura ao outro, apresentarei brevemente as noções de pata e itïp $\ddot{i}$, 
conforme argumenta Grupioni (2002, 2005, 2009b). É por meio das noções de pata e itïpï que os Tiriyó situam-se no espaço e no tempo. Essas duas noções são centrais para a compreensão da organização social tarëno, posto complementarem-se sincrônica e diacronicamente.

É comum escutar-se a tradução de pata como aldeia, embora o mais adequado seja algo como "lugar de moradia ${ }^{35 "}$ ". Pata refere-se a um local no espaço, ocupado por uma ou mais famílias nucleares, pertencentes a diferentes itïpï, termo que pode ser traduzido por "continuação" (cf. Grupioni 2002), mas que, nos dias de hoje, é mais facilmente referido em campo pelo vocábulo yana, "gente”, já apresentado na Introdução da presente dissertação. Assim, pata refere-se a uma unidade espacial, um conglomerado de casas, localizado próximo a algum curso d'água, construído a partir da abertura de uma roça, enquanto itïpï (ou yana) é uma unidade fundada no tempo, posto que possui continuidade histórica, sendo o pertencimento a determinada yana estabelecido por descendência.

Pataentu é, literalmente, a fonte ou matriz de uma aldeia. Trata-se do vocábulo em língua tiriyó que costuma ser traduzido como cacique ou chefe em língua portuguesa, ou ainda, "dono de aldeia", uma vez que a expressão entu abrange tanto a acepção de "fonte de" como de "dono de". Grupioni (2002) também vincula ao vocábulo entu a acepção "dar olhos" (2002:103), fazendo com que o dono da aldeia seja aquele que "deu olhos a determinado local de moradia". O pataentu é aquele que escolhe o local de sua aldeia e consegue reunir uma parentela bilateral para nela coresidirem.

Esse local de abertura de uma nova aldeia não é escolhido ao acaso. Além de condições ambientais adequadas, como proximidade de curso d'água, facilidade para abertura de roças e para caça e pesca, ou mesmo para o acesso às políticas públicas de saúde e educação, as novas aldeias são abertas conforme as ocupações tradicionais das diferentes yana, chamadas toposiwa:

Toposiwa é, por definição, o espaço-tempo socializado e nominado que pode vir a se constituir, o que já existe, histórica e indutivamente constituido por aqueles que abriram caminhos, ëema, construindo assim, literalmente 'laços', ma, que interligam 'em ser ao outro', ëe. De modo que, andando por estes caminhos, protagonizaram encontros com diferentes gentes, com quem, casando-se, 'misturaram-se': tüwëmoin, e fundaram 'lugares de moradia': pata, formando 'coletivos locais de co-residentes': moitü, passando a considerarse 'como reunidos-misturados': moitü me, e a produzir 'descendentes', ipëri, que, por sua vez, abriram novos caminhos, protagonizaram novos encontros, fundaram novos lugares de moradia, e assim continuam, ad infinitum, sem, no entanto, perder sua inscrição no espaçotempo em que se ancoram, enquanto pertencentes, a esta ou àquela 'continuação do espirito': itüpü, e enquanto provenientes deste ou daquele toposiwa, que se constituiu no conjunto de caminhos e lugares de percurso pelos quais transitam os que pertencem a uma itüpü especifica. (Grupioni 2002: 44)

35 Nem só humanos habitam em pata: os portos são chamados kanawa ipata - lugar das canoas, por exemplo. 


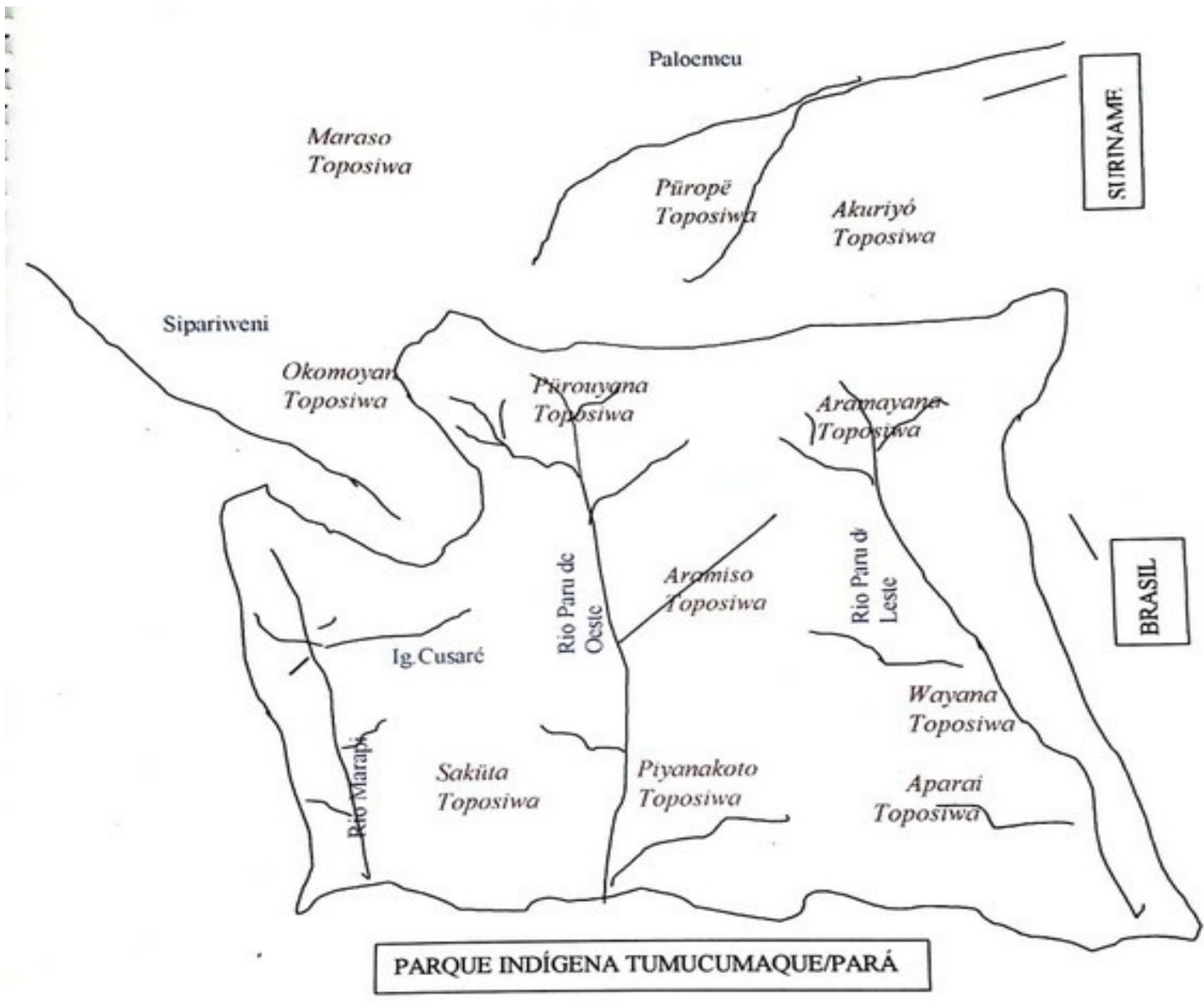

Figura 51: Conjunto de toposiwa, como apresentado em Grupioni 2002:46

Tanto em sua tese de doutoramento (Grupioni 2002) quanto em seu capítulo no livro Redes de Relações nas Guianas (Gallois org, 2005), Grupioni demonstra a tendência à uxorilocalidade como sendo principal forma de residência entre os Tiriyó, bem como o casamento entre primos cruzados bilaterais. O ideal de endogamia apresentado por outros autores, como Rivière (1969), é refutado por Grupioni conforme a antropóloga destaca a importância da diferença entre as itïpïton (ou yana) na conformação de casamentos.

Ao reunir sua parentela bilateral em sua pata, um pataentu está trazendo para sua aldeia tanto as pessoas que dele descendem, seus ipëriton, quanto seus ipëetoton, aqueles capazes de serem seus aliados. A partícula ton, em língua tiriyó, designa o plural; para fins de 
melhor entendimento, irei me referir aos termos apenas em sua versão singular. Ainda conforme Grupioni (2002:77), ipëri, literalmente, significa 'luz do braço dele', indicando aqueles que descendem do pataentu, enquanto ipëeto, literalmente 'capaz de ser braço', são seus aliados.

Ipëriton são filhos e filhas do pataentu, portanto parte de sua itïpï, de sua continuação. Como diz Pedro Achefë, interlocutor de Denise F. Grupioni: “Ketïpïhyëti kïmunkëkon. [Nós fazemos nosso espírito continuar com os fluidos de nossos filhos.]" (2002:XI), do mesmo modo que "os leitos dos rios correm, os caminhos que seguem, as árvores e os corpos animados que crescem, (...) o espírito de um homem continua através dos filhos que ele fez a partir de seu próprio sêmen, fluido denominado kuru (lit. conteúdo fértil).” (p.3). Comumente, a tradução de ipëri remete ao galho de uma árvore.

Ipëetoton, por sua vez, são as pessoas, homens e mulheres, que ajudam o pataentu em sua aldeia. Podem ser tanto consaguíneos quanto afins: a característica fundamental dos ipëetoton são sua prestatividade junto ao pataentu no cotidiano da aldeia. Grupioni (2002:81, nota 5) exemplifica diferentes 'graus de submissão' desses aliados co-residentes em relação às demandas do pataentu: por exemplo, o genro (pamun), por desposar a filha do pataentu, encontra-se em dívida com o mesmo, diferente do cunhado (kono), casado com a irmã do pataentu; neste caso, ambos consideram-se ëepëetoponan.

Mas não se restringe a essa categoria sociológica a acepção da palavra ipëeto, que também pode ser utilizada para referir-se a uma pessoa muito bonita, especialmente para elogiar o modo se vestir (incluindo utilização de pinturas corporais). Interessante notar que, nesta segunda acepção, a palavra também pode ser utilizada sem o prefixo $-i$, que denota o pertencimento à $3^{\mathrm{a}}$ pessoa do singular. Assim, pëeto, pëetome, trazem a acepção de 'muito bonito, lindo', enquanto ipëeto pode designar tanto aquelas pessoas que auxiliam o pataentu (neste caso, pataentu ipëetoton; mas também sou designada como Denise ipëeto, pois ela é minha chefa - yientu) quanto expressar a grande beleza de alguém. Importante notar que esse termo só se aplica a pessoas, jamais a objetos.

Sugere Grupioni (2002:19):

Assim, ser pëeto implica em ser braça a serviço da continuação de um espírito (...): implica em ser ajudante capaz, perspicaz, cuidadoso nas relações com os outros, comedido em seu comportamento, para que possa, de fato, ser considerado pëetome 'como bonito', por seu tamu, que o desprezará, se avaliá-lo como alguém sem capacidade para o trabalho braçal, que faz e diz coisas sem pensar direito, mostrando-se apressado, descuidado e fofoqueiro (...). 
Vemos então que a estética tarëno compreende também as capacidades de bem executar atividades, do comedimento nas relações, da prestatividade. Esses pataentu ipëetoton, 'ajudantes do cacique', muitas vezes estão a ele ligados por dívidas de casamento (sogro-genro, como mencionado acima), mas não necessariamente por isso. As principais características que fazem com que um pataentu consiga manter seus ipëetoton ao seu redor coadunam com a clássica descrição da chefia ameríndia: "um bom chefe tem de falar bem, de saber acalmar qualquer briga que ocorra na sua aldeia e dar tudo o que lhe pedirem." (Perrone-Moisés 2011:858). Retomemos, agora, a cena inicial deste capítulo, voltando ao casal de anfitriões que me recebeu: Tito e Lurdes.

Tito Meri Tiriyó é o "segundo cacique" da aldeia Missão Tiriyó, como costumam traduzir para os não-indígenas os moradores da região. Conforme conta seu filho, Aventino Nakai Kaxuyana Tiriyó, atual presidente da Associação dos Povos Indígenas Tiriyó, Katxuyana e Txikiyana, não é adequada a denominação "vice-cacique", pois faz parecer que "é menos" do que o cacique principal. Todas essas formulações só nos indicam a dificuldade da tradução do modo como esses povos pensam sua chefia, ponto esse que será maior desenvolvido adiante. O pai de Tito, Matias Ape Tiriyó, também foi um importante cacique, além de reconhecido como "pajé bom”, "desses que não mata, mas sabe curar".

Lurdes Kaxuyana, esposa de Tito, por sua vez, também vem de uma família de importantes lideranças, mas de origem Katxuyana. Sua família pertence ao grupo que foi trazido para a Missão Tiriyó da região dos rios Trombetas e Cachorro, na década de 1960. Casamentos como o de Tito e Lurdes marcam um segundo momento na relação entre os Tiriyó e os Katxuyana da região, que acompanha as descrições feitas por Gabriel Coutinho Barbosa (2011) para os Wayana e Aparai. Conforme analisa o autor, nem sempre o estabelecimento de parcerias de trocas culmina em intercasamentos bem-sucedidos, mas é a ocorrência desses casamentos que permite, por exemplo, considerar os Wayana e os Aparai coletivamente.

Como dito no início dessa seção, com o retorno dos Katxuyana à sua região de origem, observou-se a tendência dos casais compostos por homens tiriyó e mulheres katxuyana retirarem-se da região da Terra Indígena Parque do Tumucumaque em direção à Terra Indígena Katxuyana-Tunayana, atualmente em processo de demarcação física. Seguindo a 
tendência uxorilocal, essa movimentação acompanhou o sentimento comum a muitos Katxuyana de que viver na região dos Tiriyó não era viver em seu próprio local.

O caso do casamento de Tito e Lurdes pode ser explicado pela posição de prestígio da itïpi de Tito. Como pode se apreciar no mapa apresentado acima, a região da aldeia Missão Tiriyó coincide com a toposiwa de sua itïpï: essa é a região dos P̈̈rouyana, bem como de itïpïton mais antigas, que lhes conformam. Por meio das histórias de guerras, siwarapa, percebe-se como a própria toponímia local acompanha os longos e complexos episódios bélicos na região, como será apresentado na seção seguinte.

Tito é filho de Matias Apé Tiriyó, reputado pïyai pïrouyana, falecido no último ano (2018). Apé, por sua vez, era irmão de Yonare, importante chefe dessa itïpï, e um dos últimos a serem casados com 5 mulheres, de diferentes itïpïton. Assim como entre outros povos ameríndios (Clastres 2003), a poligamia era concedida apenas a chefes de grande prestígio, tendo essa prática sido abandonada com o estabelecimento das missões cristãs em ambos os lados da fronteira Brasil e Suriname.

No momento em que um pataentu já se considera demasiado velho para continuar suas atividades, ele pode conceder a outra pessoa essa posição. Apesar da tendência ser que se conceda a um filho que habite na mesma aldeia, há outros casos, como na aldeia Yawa, em que, recentemente, o cacique Podedewa passou sua posição para sua filha Yosita, ou ainda na aldeia Santo Antônio, em que provavelmente será o cunhado do cacique atual (de origem katxuyana) que ficará em seu lugar, com o retorno deste e sua família para a TI KaxuyanaTunayana.

O caso da aldeia Missão Tiriyó é especialmente interessante por se tratar de uma aldeia que não foi necessariamente aberta por seu pataentu. Localmente, muitas pessoas referem-se a essa aldeia como Missão Nova, em contraste com outra aldeia, chamada Missão Velha, que antigamente abrigava a missão franciscana ali estabelecida desde a década de 1960. Por uma série de incidentes, que culminaram com um incêndio, decidiu-se deslocar a missão franciscana para um novo lugar, aí estabelecendo-se a Missão Nova.

Essa mudança também decorre do processo de centralização de diversas yana na região da Missão Velha, que já era uma aldeia antes da chegada dos missionários franciscanos. Por já ser uma aldeia, situações de indisposição acabavam acontecendo entre seu pataentu e aqueles outros que vinham chegando para habitar próximo aos missionários e 
seus bens de consumo. Assim, mudar para um local até então desabitado, também seria um meio de aliviar tensões decorrentes desse processo.

O caso é que mesmo sendo uma região onde não havia aldeia já estabelecida naquele momento, ela seguia pertencendo à toposiwa dos Pïrouyana, que seguiram tendo privilégio na chefia. Além do que, trata-se de um local que já abrigou outras aldeias em tempos passados aldeias cujos nomes seus e também de seus pataentuton são lembrados até o presente. Contudo, quem resolveu abrir essa aldeia, pode-se considerar que foram os missionários: o que faria deles, em certa medida, pataentuton do local.

Em seu auge, quando ainda estava em vigor o Trinômio FAB-Missão-Índios (Gallois 1983), plano do governo brasileiro de vigilância da fronteira com o Suriname por meio da interação da Força Aérea, da Missão Franciscana e dos índios (estando a segunda responsável em transformar os índios em colonos, podendo ali o governo brasileiro estabelecer uma nova frente de ocupação da Amazônia), a Missão contava com diversos maquinários para produção agrícola, de olaria e mesmo de mecânica, importados da Alemanha, além de voos semanais mantidos pela Força Aérea.

Conforme o modelo decaía - até sua falência total hoje em dia, em que não há praticamente nenhum apoio por parte da Força Aérea Brasileira nem mesmo para o transporte de bens e merenda escolar, salvo com intercedência do Ministério Público Federal, também a situação da missão franciscana se viu em falência. Os maquinários estão atualmente abandonados, e outra missão católica foi recentemente convocada para substituir a anterior, cujos antigos missionários que ali viveram ao longo dessas décadas ou já faleceram ou foram aposentados.

Apesar dessa decadência, ainda é nessa região que se vê com mais facilidade o acesso às políticas públicas como atendimento à saúde, e, principalmente, o acesso ao transporte aéreo, em especial para a cidade de Macapá, onde os índios resolvem questões com bancos e documentos, vão fazer compras, estudar ou acompanhar suas famílias nesse processo, ou submeter-se a tratamentos mais complexos de saúde (APITIKATXI, APIWA \& Iepé, 2018).

Tito Meri não é o único cacique responsável pela aldeia Missão Tiriyó. Simehtu, considerado seu irmão, é o primeiro cacique, ou "cacique geral”, como se usava até pouco tempo para referir-se a sua figura. Atualmente, os Tiriyó têm entendido que essa figura de “cacique geral” não é algo do tarëno iwehto, do seu próprio modo de ser, mas sim algo imposto pelos não-indígenas no momento do contato. Como dito, até recentemente, Simehtu 
era considerado como cacique principal da Missão Tiriyó, o que se modificou por diversos fatores, como problemas de saúde e mesmo indisposições com pessoas de sua aldeia e de aldeias dos arredores.

Há alguns anos, o Exército Brasileiro, que mantém um pelotão de fronteira na região, decidiu que construiria uma Mini Central Hidrelétrica $(\mathrm{MCH})$ nas imediações da aldeia Missão Tiriyós, mais precisamente, próxima à aldeia Paruwaka. Para tanto, seria necessário proceder com a explosão de lajedos de pedra no curso d'água da região - lajedos estes que abrigam espíritos, dentre outras consequências. A negociação em torno deste empreendimento - atualmente embargado pelo Ministério Público Federal e pelo IBAMA - resultou em tamanhas tensões entre os povos indígenas da região que até hoje este é um assunto sobre o qual não há interesse em retomar as negociações.

O mal entendido principal deu-se com o procedimento equivocado por parte do Exército de não consultar de modo adequado às comunidades indígenas. Ao assumirem a figura do "cacique geral" como instância suficientemente adequada para tomada de decisões e única a ser beneficiada com a construção da obra em questão, foram provocados desentendimentos sérios entre diferentes caciques, influenciados inclusive pela ideia acima apresentada de toposiwa, afinal era como se o cacique ligado a uma região estivesse tomando decisões a respeito de outra toposiwa. O que fica evidente neste caso, mesmo que sumariamente apresentado, são dois pontos fundamentais para se compreender a chefia tarëno: 1 . não cabe ao chefe tomar decisões por si próprio; 2 . a sovinice é repudiada.

O mesmo pode ser dito para o modo como esses povos têm percebido sua associação, a APITIKATXI. A associação não pode conseguir projetos apenas para uma aldeia, ou que beneficiem apenas uma parte pequena das pessoas; tampouco pode a associação tomar decisões sem consultar "suas bases", como expressa-se sua diretoria, já se apropriando do vocabulário ligado às lutas sociais. Segundo expressaram-se durante oficina para elaboração de seu Protocolo de Consulta e Consentimento, tanto cacique quanto associação são portavozes de suas comunidades.

E é no momento das assembleias que essas comunidades se fazem ouvidas por sua associação, e também que se discutem assuntos relacionados aos não-indígenas, que exigem posicionamentos de todas as aldeias. Como será explicitado mais adiante neste mesmo capítulo, as assembleias podem ser vistas como um dos momentos contemporâneos onde mais se faz uso do aparato completo das roupas tradicionais, conforme apresentadas no capítulo 2. 
Ao fazerem questão de me levar para diversas outras aldeias, Lurdes e Tito cuidavam de distribuir-me entre seus ipëetoton, evitando acusações de sovinice, ainda mais tratando minha visita de um assunto tão cobiçado como são as miçangas. Aliás, é interessante destacar aqui que são dois os modos como acontecem as distribuições de miçangas nas aldeias tarëno, seja nas Terras Indígenas Parque do Tumucumaque e Rio Paru d'Este, como nas Terras Indígenas Trombetas-Mapuera, Nhamundá-Mapuera e Kaxuyana-Tunayana.

Quando a distribuição deve ser pública, como na ocasião que abre esse capítulo, as mulheres primeiro misturam o conteúdo de todos os pacotes em alguma grande bacia ou balde. Em seguida, todas as mulheres interessadas levam (ou enviam), cada uma delas, seu próprio recipiente para o recebimento de miçangas. Elege-se uma concha ou copo para servir de medida para essa distribuição, que vai enchendo todos os potes de miçangas, às vistas de todas, que vão garantindo que todos os potes recebam a mesma quantidade, sem que nenhum seja esquecido. Porém se não se trata de uma distribuição pública, mas de um presente de miçangas oferecido a alguma mulher específica, faz-se questão que a entrega seja o mais sigilosa possível, longe das vistas de todos, escondendo-se o pacote de miçangas em alguma bolsa, pano ou roupa, para que não haja ciúme por parte de outras mulheres.

Passemos agora à próxima seção, onde apresento alguns pontos relativos a diferentes tipos de guerras e de corpos nelas implicados.

\section{Guerras e Corpos}

Oroientu é uma pequena aldeia localizada nos arredores da Missão Tiriyós, na Terra Indígena Parque do Tumucumaque. As nove famílias dividem-se pelas casas que se espalham na região de campo, próximas (mas nem tanto) do igarapé Muneni, que deságua no rio Paru de Oeste. A aldeia não se localiza no mesmo local de outra aldeia antiga, como é comum na região, já que um dos principais motivos de sua fundação ser a sugestão de um frei franciscano de que os familiares de Peti Tiriyó, pataentu do local, cuidassem de algumas cabeças de búfalo por ali. O primeiro local em que o frei sugeriu que a aldeia ficasse foi uma péssima escolha: muito distante de qualquer curso d'água, fez com que os moradores se deslocassem para o local atual, que ainda assim implica numa longa caminhada até o pequeno 
igarapé, mesmo em épocas de cheias, pois o braço do igarapé que serpenteava até próximo de Oroientu desbarrancou recentemente, tendo seu fluxo interrompido.

Peti Tiriyó é o pataentu do local, isto é, chefe e fundador da aldeia. Como dito anteriormente, o sufixo -entu é comumente traduzido como "dono", mas também designa a "fonte" de algo. No caso de Oroientu, Peti não é apenas o fundador e chefe, ou cacique, como costumam traduzir para português os falantes de tiriyó, mas também o homem mais velho do local, e aquele que mais conhece sobre histórias e, principalmente, sobre cantos tarëno, chamados eremi. Sua esposa atual é Guadalupe Tiriyó, filha de um dos mais reputados chefes, desde o contato com os freis franciscanos na década de 1960, mencionado anteriormente, o já falecido Yonare Tiriyó. Guadalupe só não é a mulher mais velha da aldeia porque uma das esposas de Yonare, sua mãe classificatória, também lá reside, a senhora Kawaru Akëe.

O casal Peti e Guadalupe aceitou me receber por alguns dias em Oroientu, para me contarem Tarëno iwehtomponpëton, Histórias dos Antigos, conforme eu havia manifestado meu interesse na visita que realizei para apresentar minha pesquisa para os presentes. $\mathrm{Na}$ ocasião, eles me disseram que para eu escutar essas histórias, deveria dormir em sua aldeia por alguns dias, e assim foi feito. Meus anfitriões me receberam com muita sakura, a bebida fermentada da região, feita a partir de mandioca e batata-doce, num domingo, e a cada dia nos encontrávamos na tënusën ipakoro, casa de guardar bebida, para escutarmos histórias e cantos contados por Peti e Guadalupe, às vezes também por Kawaru, e traduzidos por Luzio Kaxuyana, genro do casal.

A casa de paredes de madeira e telhado de palha abrigava não apenas alguns baldes de bebida, mas também um grande tacho usado no preparo da mesma, além de outros instrumentos, como tipiti e peneira. Levamos para lá uma mesa para que eu apoiasse meu material (caderno e câmera), além de alguns bancos. Meus anfitriões, de modo muito cortês, insistiram para que eu me sentasse num mïnyere, banco tradicional feito por Peti, que fez questão de me dizer que quando eu lá voltasse, ele já teria feito um novo banco para mim, dessa vez com os desenhos que lhe cabem.

Ao pedir para alguém tarëno contar uma história, é provável que a pessoa diga que não sabe, que é preciso conversar com alguém mais velho, mas com um pouco de insistência, logo é possível escutar histórias que tratam, sobretudo, de guerras. Durante minha curta estadia em campo, escutei diversas histórias, mas certamente a narrativa mais recorrente foi a da guerra entre os Pïrouyana e os Wayana. Os Pïrouyana compõem um dos yana mais 
destacados da região: muitos dos grandes chefes e guerreiros fazem parte desta continuação, tradução sugerida por Denise Fajardo Grupioni (2002). Literalmente, P̈̈rouyana é genteflecha, geralmente ligados a outros dois yana, Aip̈̈pa e P̈̈roupo, sendo algumas vezes sugerido que são os descendentes destes dois grupos. Uma das características reputadas aos Pïrouyana, assim como aos Aipïpa, seria sua rapidez.

A guerra com os Wayana haveria começado por conta do assassinato de uma criança filha de pai Wayana e mãe Tarëno, pelo próprio pai. A partir daí, os Pïrouyana juntaram-se

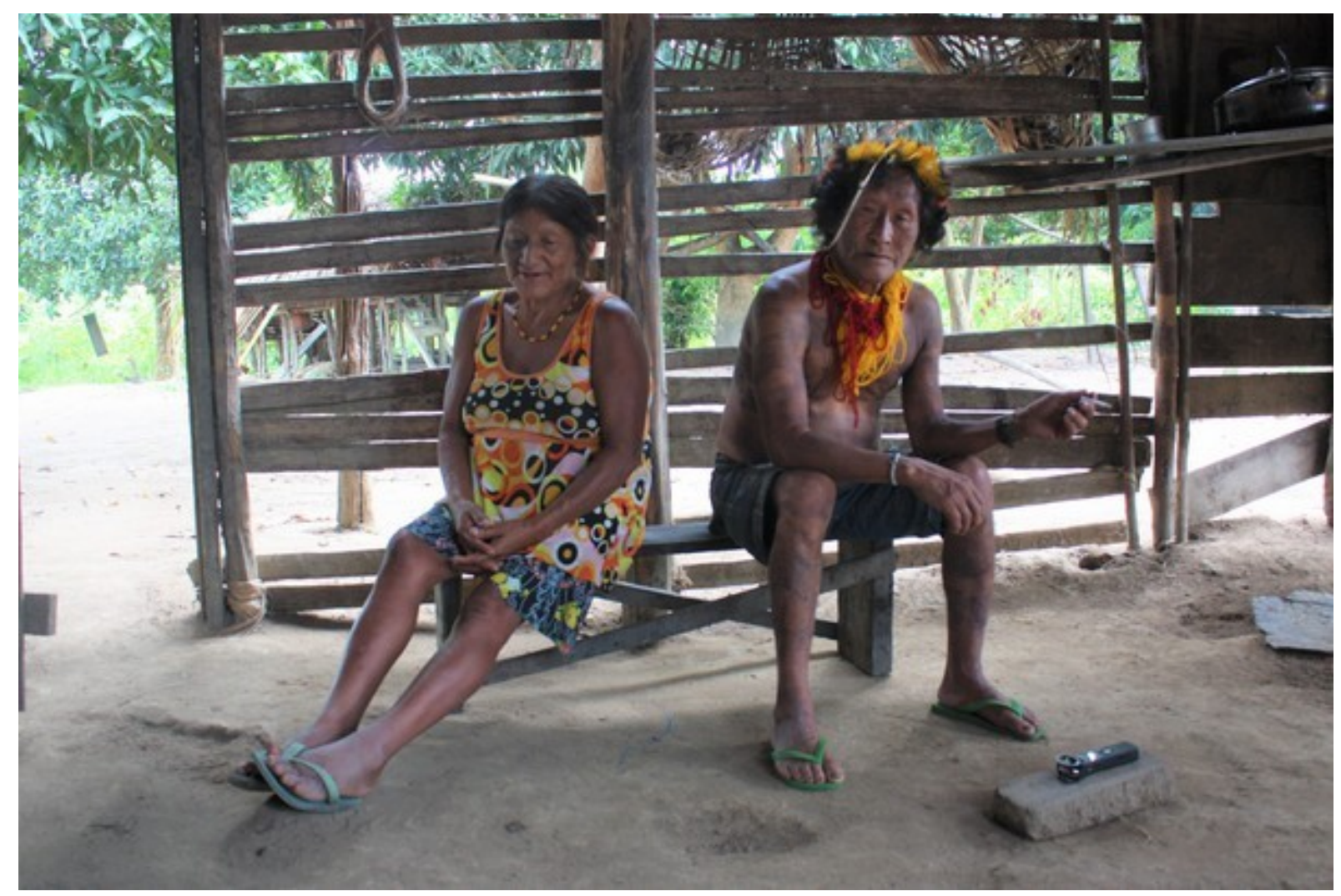

Figura 52: Guadalupe e Peti Tiriyó, aldeia Oroientu. Fevereiro de 2019.

com diversos outros yana para se vingarem do ocorrido. São muitos os detalhes dessa guerra, alguns dos episódios mobilizando heróis culturais, mas de modo geral destacando o preparo do corpo para a guerra, além de diversas táticas e alianças, mais ou menos bem sucedidas. Seguindo algumas das versões da história, foi um aliado pertencente aos Akïyó que teria ficado com pena de um casal wayana, permitindo que eles fugissem, e é apenas por isso que os Wayana conseguiram se recuperar e voltar a ser numerosos.

Os longos episódios de guerra encerram-se com a percepção de um pïyai de que a continuação deste tipo de comportamento iria acabar com todos eles. Este püyai vai então para 
a floresta, onde consegue ver, dentro de uma montanha ${ }^{36}$, uma grande festa, onde todos os animais bebem e cantam muito, "como numa aposta", para ver qual tinha o canto mais bonito. Com enfatiza Peti, o pïyai via cada um desses animais como gente, e ele foi assim aprendendo os diferentes cantos e vendo também os diferentes enfeites. Assim, ao retornar para sua aldeia, o püyai anuncia que dali para frente, não haverá mais guerra, mas sim festas com bebidas e cantos.

Essas guerras são designadas pelo termo siwarapa, e muito da topografia tarëno está ligada a esses episódios. Um exemplo é o nome de diversas aldeias, que, numa primeira resposta, replicam o nome do igarapé ao qual estão ligadas, sendo que esses igarapés carregam, por sua vez, o nome de guerreiros que participaram dessas batalhas, como é o caso do próprio igarapé Muneni, que, antes de passar por Oroientu, banha aldeia de mesmo nome. Outro caso da topografia ligada aos eventos de siwarapa é o das cavernas que existem na região, sendo a mais conhecida delas chamada de Tïmenuren, "pintada", ou de Mawimë.

Tïmenuren localiza-se nas proximidades da aldeia Ponoto, cujo pataentu é Marinka, também filho de Yonare e reputado conhecer das histórias dos Tarëno. Durante meu trabalho de campo, pude visitar essa caverna, conforme sugestão de Tito Meri Tiriyó e Lurdes Kaxuyana. Antes, é claro, passamos por Ponoto para que eu apresentasse minha pesquisa e minhas intenções para Marinka, para que ele autorizasse nossa ida ao lugar, ao que ele consentiu e aprovou o modo como procedemos.

Não existem pesquisas arqueológicas aprofundadas na região, embora o arqueólogo Manuel Calado (2009) destaque a situação particular dos sítios da região, em que a população local se relaciona de modo próximo com os mesmos. É o que pude perceber pelos diferentes relatos: Peti frisou que todas aquelas pinturas dizem respeito à siwarapa, e que nesse tempo das guerras, aldeias inteiras escondiam-se nas montanhas. Segundo Peti, há ali muitos desenhos de nopo, frequentemente traduzido como escudo ou armadura. Trata-se de uma peça de vestuário feita de alguma tipo específico de taboca e que protegia os guerreiros das flechas dos inimigos. Não conheci ninguém que saiba fazer um nopo, nem é possível ter certeza de que ainda há pessoas vivas que tenham visto algum exemplar. Ainda assim é uma peça sempre descrita nos relatos das guerras, e há um exemplar de uma armadura de tabocas no acervo técnico do Museu Paraense Emílio Goeldi.

36 As montanhas são, por excelência, local de moradia dos espíritos, conforme comunicação pessoal com Denise Fajardo Grupioni e informações levantadas em campo. Um exemplo é o relato de que, após o falecimento de Matias Ape Tiriyó, grande parte dos espíritos que o acompanhavam voltaram para as montanhas. 
Outro ponto interessante no que se refere a Timenuren é que ali estariam depositadas pequenas flechas que apenas quem tem pïyai consegue acessar. Mais acima dessa caverna, uma outra teria sido uma casa apenas para guardar flechas. Aliás, nas histórias de siwarapa, é frequente essa menção a casas que guardavam flechas "até o teto, só flechas mesmo". Outras cavernas da região também teriam desenhos retratando cenas de guerras.

As histórias de siwarapa também mencionam o preparo corporal dos guerreiros antes de irem para as batalhas. Esses preparativos fazem menção principalmente à baixa ingestão tanto de água quanto de outros alimentos. Também a pintura do corpo é mencionada, toda de vermelho, como sangue, mas de urucum. As miçangas, contudo, não eram utilizadas, afinal, segundo Peti, são muito pesadas. Colares, pulseiras, bandoleiras eram todos de maru, algodão.

Em algumas versões, os animais que o pïyai observou cantando e dançando dentro dessa montanha chegavam a usar miçangas, em outras, também apenas algodão. Essas pinturas e adornos podemos ver ainda hoje, como o caso da diadema de plumária vermelha que o pica-pau tem. O repertório de eremi dos Tarëno vêm desse episódio, em que é a partir da observação e da imitação que o pïyai aprende, 'pega', esses cantos e danças. É também desse movimento de pegar, de observar e imitar, que é composto o repertório de padrões gráficos dos povos da região.

De modo sintético, eremi é o termo utilizado para os cantos tradicionais, que também são acompanhados de danças. Não são contempladas por esses termos quaisquer outras músicas, nem mesmo aquelas evangélicas gravadas nas línguas indígenas da região. De modo geral, o repertório de eremi é oriundo desse momento em que o pïyai encontrou os animais numa festa, sendo que muitas delas são identificadas com o nome do animal em questão. Não necessariamente as palavras que a compõem falam do animal: no mais das vezes, é o próprio animal que conta como é seu modo de dançar, ou como é belo seu canto. Outra tema comum é a bebida. Cada animal possui seu jeito de dançar, e esse jeito também é imitado no momento do canto. Essa separação entre canto e dança não funciona neste contexto de eremi, pois são acoplados: a dança e o canto acontecem ao mesmo tempo. Similar a esse movimento de acoplagem é o tambor tëefa, que é conformado de um buraco no chão, no qual se coloca uma madeira em cima (como um pedaço de canoa), e que é tocado enquanto se dança; as sementes e guizos que pendem nos keweyu também exercem valor percussivo durante a dança. $\mathrm{O}$ próprio modo de tocar maraca também implica numa certa dança, e esse paralelismo pode ser 
estendido até ao som feitos pelas sandálias havaianas, portadas de modo unânime pelas pessoas, arrastando-se ritmadamente pelas casas de reunião em momento de festa.

\section{Um "estilo regional"}

Chama a atenção que, nas narrativas de Peti Tiriyó, a passagem das guerras para as festas traz também o uso das miçangas como ornamentação apreciada e imitada pelos Tiriyó a partir do que observam em outras gentes. Após os longos episódios de guerras, já não há mais a necessidade daquela leveza anteriormente requerida - o que não significa dizer que não é mais necessário nenhum cuidado corporal, como fica evidente ao observarmos a conformação de um "estilo regional" entre os povos indígenas do Amapá e do norte do Pará nos enfrentamentos contemporâneos com o Estado Nacional (Gallois 2017).

Esses enfrentamentos são variados: reuniões com Secretarias de Educação ou da Saúde Indígena, protestos (principalmente na cidade de Macapá), apresentações cada vez mais frequentes em contextos universitários (cada vez mais ocupados por acadêmicos indígenas), recepção de representantes de diferentes esferas do governo nas terras indígenas, mobilizações em âmbitos regionais ou mesmo nacionais e internacionais, tal o Acampamento Terra Livre, em Brasília.

Nesses espaços de luta política contemporânea, a ornamentação corporal segue ocupando lugar de destaque e cuidados específicos. Evidentemente, isso não é exclusividade entre os povos falantes de língua karib do sudeste das Guianas, como podemos acompanhar por toda parte onde existam povos ou minorias políticas reclamando seus direitos frente ao Estado. O que iremos aqui destacar é a especificidade do caso, fazendo ecoar a proposta de Manuela Carneira da Cunha (2009:373), da convivência entre "cultura" e cultura, posto que:

\footnotetext{
a coexistência de "cultura" (como recurso e como arma para afirmar identidade, dignidade e poder diante de Estados nacionais ou da comunidade internacional) e cultura (aquela "rede invisível na qual estamos suspensos") gera efeitos específicos.
}

No caso do Amapá e do Norte do Pará, nessas arenas de enfrentamento com o Estado, vê-se a consolidação de "um coletivo portador de marcas próprias, adotando vestimentas, pinturas e modos de falar de guerreiros" (Gallois 2017: 4), onde se destacam o uso das tangas vermelhas, das bandoleiras de miçangas e das diademas de penas, bem como de pinturas corporais. Esse coletivo engloba, principalmente, os povos indígenas Wajãpi, Tiriyó, 
Katxuyana, Wayana e Aparai, estendendo-se em menor grau de similitude aos povos indígenas do Oiapoque (Galibi, Galibi Marworno, Karipuna e Palikur).

Se essas vestimentas, bem como a apresentação de danças e cantos tradicionais, aparecem como marcas inexoráveis das atuações nessas esferas públicas, no cotidiano dos jovens que se mudam para a cidade, principalmente em busca da continuidade de sua educação escolar, percebe-se um grande contraste. Isso porque, nesses casos, o comum é que se procure esconder ou camuflar essas marcas que evidenciam suas corporalidades indígenas (Gallois, idem: 12).

Ainda que a proposta desta pesquisa não passe por uma etnografia intensiva desses contextos, não podemos deixar de concordar com Gallois (ibidem), mobilizando o termo em língua wajãpi -reko, cuja tradução cada vez mais frequente pelos Wajãpi que se encontram nessas situações é a palavra cultura:

\begin{abstract}
Um estilo regional que se consolida nas manifestações realizadas em Macapá e permitem aos representantes dos povos dessa região adensar seu -reko específico, quando participam dos grandes eventos indígenas em Brasília. Um -reko, como se sabe, é necessariamente produzido como efeito relacional de encontros com outros.
\end{abstract}

Pode-se pensar que a conformação desse "estilo regional" implica numa certa devoração coletiva, na qual tampouco diluem-se totalmente as especificidades dos diferentes povos acima mencionados. Em outras palavras: os elementos compartilhados que destaquei acima tanto evidenciam as redes de relações que perpassam toda a região, conforme pode-se atestar desde os primeiros cronistas, quanto esses mesmos elementos permitem que se afirmem especificidades entre esses povos indígenas. $\mathrm{O}$ uso que os Wajãpi têm feito de colares de tramas de miçangas é um exemplo disso, pois as mulheres wajãpi não se interessam pelo desenvolvimento dessa técnica, ao contrário das mulheres Katxuyana, Tiriyó, Wayana e Aparai.

Esse apreço pelos adornos dos vizinhos, que nas extensas narrativas míticas aparecem como inimigos temíveis, remete à lógica da relação entre predação, beleza e alteridade, apresentada tanto no capítulo anterior quanto em estudos como Grupioni (2009), Van Velthem (2003) e Gallois (2012), dentre outros. A relação entre os saberes, a alteridade e a corporalidade é assim expressa por Gallois (sup. cit): "os saberes se inscrevem no corpo e por isso, os corpos têm a capacidade de portar saberes distintos, que garantem capacidades valiosas e ao mesmo tempo, perigosas.” (p.2). 
Na próxima seção, vemos que esse mecanismo é comum a toda região, em diferentes contextos, como poderemos atestar pela análise do canto kahyana denominado Orokowëti Yoremuru - canto da miçanga.

\section{Miçangas em cantos: a relação pawana}

Dentre as surpresas que as tecnologias contemporâneas podem trazer, destaco uma mensagem de áudio bem curta mas significativa: Ângela Kaxuyana me enviou, no final de 2017, um pequeno trecho de sua avó, Maria Vieira Kahyana, entoando o que elas chamaram de Orokowëti Yoremuru, canto da miçanga. O áudio era realmente curto, cerca de 8 segundos, e bem baixo, então pedi para que ela me enviasse uma versão mais nítida e longa, mas sua resposta foi categórica: uma versão mais extensa só seria possível visitando sua avó em sua aldeia, Pürho Mïtï, localizada no rio Trombetas, Terra Indígena Kaxuyana-Tunayana.

O contexto que me permitiu realizar essas visita foi a já mencionada Festa Kahyana, sendo a avó de Ângela uma das Kahyana que foi levada para a região da Missão Tiriýó no final da década de 1960, e também uma das mais entusiastas no retorno à sua terra de origem. Segue a transcrição do canto, realizada graças à colaboração do senhor Mário Kaxuyana, em Macapá (dezembro, 2018):

$\begin{array}{ll}\text { PAWA WANARÏ, PAWA WANARÏ } & \text { Os visitantes vieram, os visitantes vieram } \\ \text { PAWANA KÏNEHNE } & \text { Eles chegaram } \\ \text { PAWA WANARÏ } & \text { Os visitantes vieram } \\ \text { PIYANAKOTO SARUKUMARI } & \text { (Duas etnias dos pawana) } \\ \text { PAWANA KÏNEHNE } & \text { Os Pawana chegaram } \\ \text { PANATXERE TAWONO } & \text { Eles estão enfeitados com brincos } \\ \text { PAWA WANARÏ, PAWA WANARÏ } & \text { Os visitantes vieram } \\ \text { WARAKUMI TAWONO } & \text { Eles estão enfeitados com warakumi (perneira) } \\ \text { PAWANA KÏNEHNE } & \text { Os visitantes vieram } \\ \text { ONENE PEN KÏNEHNE } & \text { Eles vão embora }\end{array}$


Na ocasião da Festa Kahyana, Maria Vieira e Ângela fizeram questão que eu gravasse alguns cantos por ela entoados, e traduzidos ou comentados por Ângela. Dentre as observações relativas à orokowëtu yoremuru, elas destacam a centralidade do uso da flauta de osso de veado. Segundo Maria Vieira, haveria mesmo outra música para miçangas, apenas com os sons das flautas, sem a utilização de palavras. Uma observação de Mário Kaxuyana a respeito da língua em que foi cantada a Orokowëti Yoremuru explica o porquê das pessoas mais jovens não conseguirem ter uma compreensão clara da mesma: não se trata nem de língua wërikyana (katxuyana) nem o kahyana correntes, mas sim um canto com palavras antigas, específicas de cantos.

Observa-se que, apesar do canto ser referido como "de miçangas", essa palavra não aparece nenhuma vez. O que se destaca são os diversos adornos que portam os pawana que estão chegando, notadamente Piyanakoto e Sarukumari. Antes de adentrarmos nessa importante categoria pan-guianenses, menciona-se o lugar que os Piyanakoto, ou gentegavião, ocupam no contexto tarëno., posto costumarem referenciar povos temidos. Assim, dentre os elementos que os caracterizam, estão os cabelos longos, às vezes com cabeça mesmo de gavião, às vezes mencionados como povos isolados. Segundo me traduziu no mesmo momento Ângela Kaxuyana, Piyanakoto, naquele contexto, queria dizer "estrangeiro". Trata-se, portanto, da descrição da chegada de estrangeiros, isto é, possíveis parceiros de trocas, estando eles belamente enfeitados.

Pawana como categoria pan-guianense é um tema recorrente na literatura regional (Dreyfus 1993, Barbosa 2002, 2007). A descrição do termo feita por Barbosa (2007) indica que

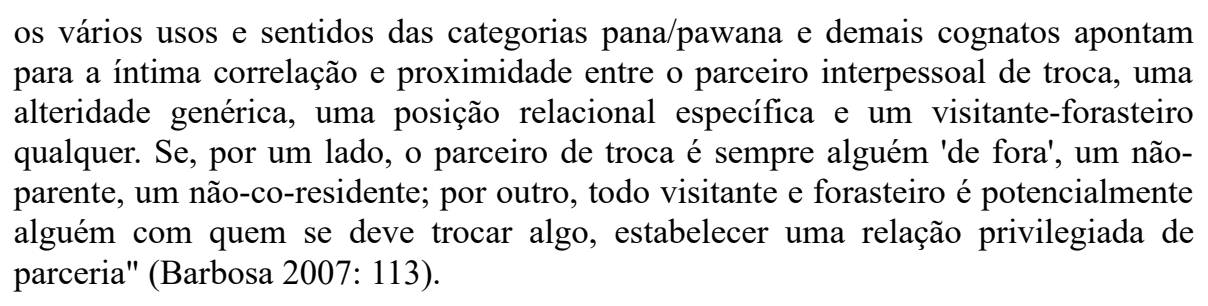

Difícil compreender o porquê de Howard (1993:238) enfatizar pawana enquanto um termo, quando sua própria etnografia enfatiza a posição do visitante, indígena ou não, como 
aquela a que se refere o vocábulo - marcando essa categoria muito mais como uma relação existente entre pessoas do local e outsiders do que um termo propriamente dito. Howard contesta a caracterização dos povos indígenas das Guianas como "atomísticos", "individualistas" e "mais simples", consoando com as críticas de Redes de Relações nas Guianas (Gallois org, 2005). Argumenta Howard (idem), para o caso Waiwai, que

a necessidade de 'estrangeiros' é tida como um traço intrínseco e constitutivo. De certo ponto-de-vista, pode-se considerar a estrutura social waiwai como um ‘exoesqueleto' que exige relações com outros grupos para se manter em pé.

Jacome (2011:40), sintetiza de modo interessante como a relação pawana prolonga-se no tempo:

\begin{abstract}
A permanência dessas redes de intercâmbio, apesar do caráter esporádico dos encontros, estabelece vínculos fortes entre os parceiros que são mantidos por uma relação de reciprocidade, onde a troca não é só uma relação comercial, mas de dádiva e contra-dádiva. É por isso que as redes são estáveis, algumas com longa duração cronológica, pois a relação entre os parceiros está sempre em constante desequilíbrio, e, portanto, precisa ser sempre reequilibrada.
\end{abstract}

\title{
O corpo enfeitado do püyai
}

Apesar do destaque dado até o momento à figura do pataentu como categoria fundamental para pensar a política entre os Tiriyó, não podemos deixar de notar o que já destacou Sztutman (2013), dentre outros autores, a respeito da complementariedade das figuras do chefe e do xamã, mobilizadoras de coletivos por meio da articulação de diferentes relações, incluindo planos diversos e seres humanos ou não-humanos ${ }^{37}$. No caso tiriyó, essa complementaridade já estava indicada por Grupioni (2002), inclusive já mobilizando a figura do pïyai, denominação dos xamãs nas línguas karib do sudeste guianense, como categoria cosmopolítica (p.103).

Não cabe nos objetivos dessa pesquisa aprofundarmo-nos nesse tema de extrema complexidade, mas é interessante notar o local de liminaridade que a figura do pïyai ocupa entre os Tiriyó nos dias de hoje, em que praticamente pode se dizer que já não há mais

37 Daí a implicação no que a antropologia das ciências tem chamado de cosmopolítica, conforme Stengers (2003) e Latour (2004). 
pessoas que detenham todos os conhecimentos que conformam um pïyai. Esses conhecimentos notadamente mobilizam a capacidade de matar pessoas à distância - daí a cautela existente em relação a essa figura. Outras capacidades vinculadas aos saberes e práticas do pïyai incluem a cura de diversas doenças (sempre entendidas como ocasionadas por ação de desafetos) e a reversão de picadas de cobra por meio de técnicas específicas que incluem a execução de determinadas eremiton.

A deferência e a cautela que as pessoas experimentam em relação ao pïyai é notada ao longo do tempo e do espaço, como podemos ver até mesmo nos relatos de Crevaux (1883). Em consonância com a estética estendida por toda a região, o pïyai costuma ser descrito como alguém com ornamentação destacada. Exemplo curioso do modo como isso aparece contemporaneamente é a apreciação indígena da figura litogravada, apresentada a seguir (fig. 53), que, por conta da técnica utilizada, compõem-se de diversas linhas utilizadas para a expressão do personagem retratado - o que é percebido pelo olhar indígena como um corpo coberto de pinturas corporais.

$\mathrm{Na}$ narrativa de Peti Tiriyó mencionada acima, o püyai ocupa lugar central no encerramento do ciclo de guerras, o que desencadeia nas festas, com bebidas, cantos, danças e adornos, incluindo aqueles feitos de miçangas. Essa relação entre püyai e miçangas podemos perceber elementos interessantes para se compreender o que fazem fazer as miçangas entre esses povos indígenas, conforme sugere a abordagem de Bruno Latour $(2002,2008)$.

A alusão a essa abordagem justifica-se a partir da resposta que Peti me deu quando the perguntei se havia, entre os Tarëno, algum canto de miçangas. Por já ter tido contato com o orokowëti yoremuru apresentado por Maria Vieira Kahyana, acima transcrito, imaginei que seria possível a existência de alguma samura eremi. Contudo, Peti foi categórico em sua resposta: "Samura não grita!", com a qual me vi inteiramente de acordo (e mesmo um pouco desconcertada pela pergunta tão tola). Que miçangas não gritem nem cantem, é algo bem fácil de aceitar. Mas o fato é que se há ações que elas não praticam, não se pode ignorar - a essa altura de nossa argumentação - que elas produzem sim diversos outros efeitos, muito mais ligados à materialidade e à visão. 


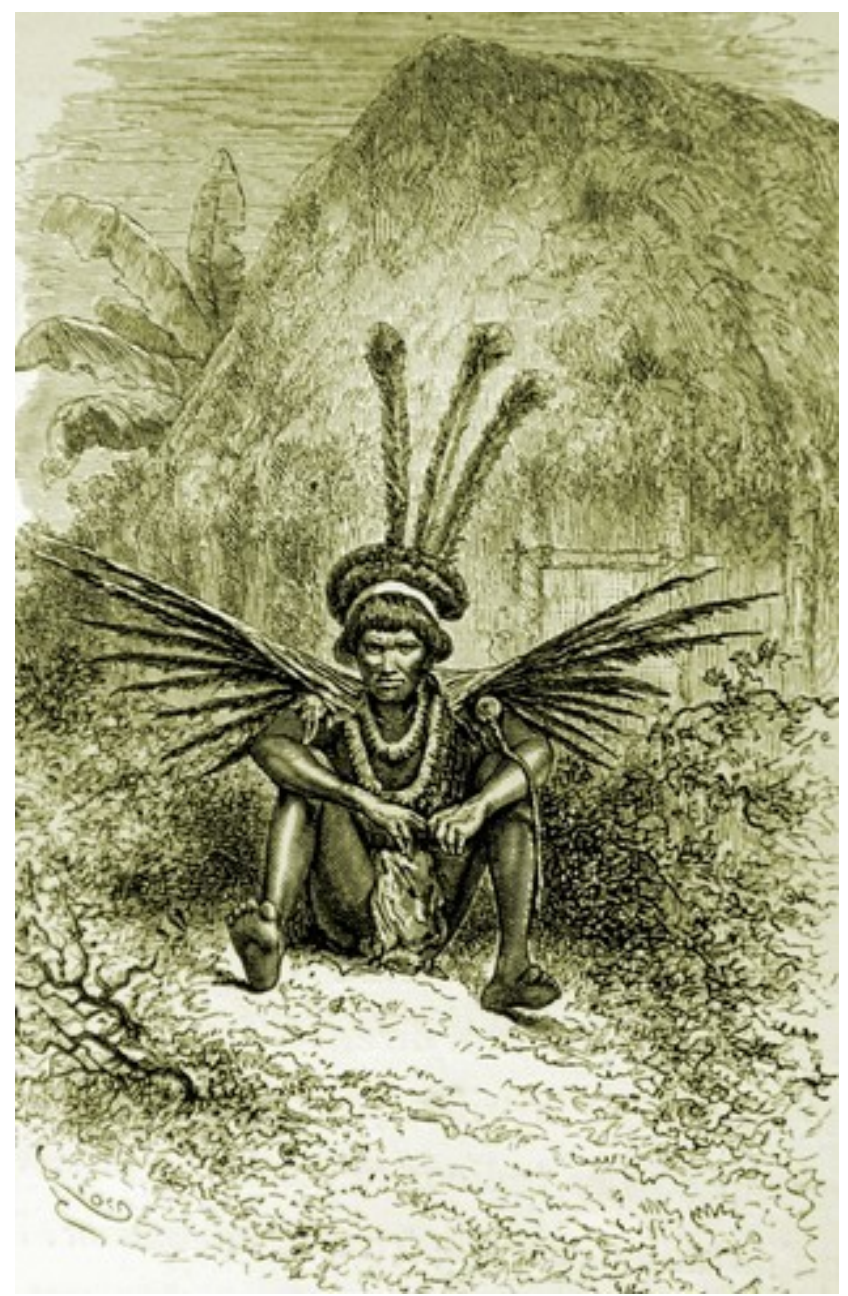

Figura 53: Ilustração de um püyai (Crevaux 1883).

A beleza excessiva e perigosa mencionada por van Velthem $(1998,2003)$ para os Wayana, como mencionado ao longo dessa dissertação, também ecoa na estética tiriyó (cf. Grupioni 2009a), fazendo com que no imaginário corrente das pessoas já nascidas após a concentração populacional em torno da Missão Franciscana, o pïyai seja alguém que tem o corpo coberto de miçangas. Os relatos de pessoas mais velhas, que chegaram a vivenciar sessões xamânicas, porém trazem exposições diversas.

Foi assim que Suzana Tiriyó, uma senhora que se enquadra nessa segunda categoria mencionada, surpreendeu as demais mulheres que participavam de uma oficina em que apresentei minha pesquisa para elas, em Macapá. Após essas mulheres mais novas me afirmarem que os pajés usavam sim bastante colares de miçangas, Suzana, em sua delicada expressão, disse que eles até poderiam usar se quisessem, mas que ela nunca viu. Então, ela 
nos narrou como aconteciam as sessões de cura que ela mesma era submetida quando era criança.

Em sua descrição, Suzana destacava o maracá do pïyai. Segunda ela, ele tinha um maracá específico, que ele sacudia, sendo que seu conteúdo não podia ser visto por ninguém, apenas pelo próprio pïyai (novamente, ênfase entre ver e saber). O maracáera sacudido, e então subia sozinho, subindo no alto da casa específica que em que o pajé realizava a cura. Depois, sem ninguém saber como, sem passar pela porta, ele retornava para a casa.

O conteúdo de dentro da maraca é às vezes designado como kuri. A tradução para o termo em português é complexa. Frikel indica que kuri eram pedras que possuíam tanto macho quanto fêmea, e que eram enterradas na roça para que a mesma fosse fértil. Os kuri também me foram narrados como esferas brilhantes, semelhantes a bolinhas de gude, de uso dos pajés, mas que eram muito perigosas, podendo tanto servir para enfeitiçar e adoecer pessoas, quanto para o bem, como indicar se um forasteiro era "um amigo vindo trocar coisas" ou alguém vindo fazer guerra. Kuri também é indicado como espíritos. Neste caso, ouvi descrições que falavam que eram pedras brancas, e outras dizendo que eram pequenas figurinhas pretas.

O que parece é que as pessoas atuais não tiveram acesso aos kuri, ou que não têm autorização para falar a respeito deles. Mas é importante notar que ainda assim eles são centrais no episódio do pakara de Yonare, levado por Frikel, ninguém sabe para onde, e que são muito temidas (foi-me dito que talvez nem fosse mesmo muito bom trazer de volta esse pakara, caso o encontrássemos, pois ele pode até mesmo fazer cair o avião em que ele estiver sendo transportado). O interesse de Peti, Guadalupe e Luzio em encontrá-lo é repleto dessa ambiguidade: ao mesmo tempo que gostariam muito, eles também têm receio do que poderia acontecer. A resolução dada por Peti é que, no momento em que for oportuno procurar esse cesto, que todos estejam bem enfeitados, inclusive eu, e inclusive de miçangas, pois assim esses espíritos ficarão mais contentes.

A sugestão de Peti de que os espíritos ficarão mais contentes - portante menos ameaçadores - com pessoas enfeitadas pode ser contrastada com aquela feita por Nazaré, viúva de Matias Ape Tiriyó, reputado como um dos últimos detentores de conhecimentos de pïyai (alguns dos quais passou para Nazaré). Nazaré concordou com Suzana, de que os pajés não havia uso de miçanga pelos pajés durante suas sessões. Quando indaguei Nazaré o porquê 
desse não-uso, ela me disse para o püyai é importante agradar os espíritos que o acompanham, e que provavelmente eram os espíritos que não gostavam de miçangas, afinal "não são gente".

Apesar de divergências um tanto quanto geracionais em relação aos adornos utilizados pelo pïyai, em todos os relatos a ornamentação é fundamental, com destaque para o uso do algodão nas narrativas feitas pelas pessoas mais velhas. A relação entre os espíritos e as miçangas talvez possa nos expressar que as miçangas são de fato algo da apreciação humana, e que mesmo que os espíritos não as apreciem tanto assim, eles preferem gente enfeitada como Tarëno do que gente que não marque adequadamente o seu próprio corpo.

\section{Corpos políticos em ações}

O que seria a política nos modos de vida ameríndio? Seguindo a linha argumentativa proposta por Beatriz Perrone-Moisés (2015), a partir de leituras de etnografias referentes a povos ameríndios de toda a extensão do continente, e autores clássicos da antropologia, como Mauss, Clastres e Lévi-Strauss, a política há de repousar sobre o eixo Festa/Guerra, e há de ressaltar as mais marcantes características da chefia ameríndia: "O fato é que os índios têm chefes sem poder, generosos por dever de ofício." (Perrone-Moisés 2015: 36). Foi enquanto acompanhava o processo de preparação de uma festa na aldeia Bona, mais precisamente no que tangia a distribuição de miçangas e tecidos, que Beatriz Perrone-Moisés ouviu de Merekuku Aparay a frase que lhe possibilitou desenvolver sua tese de livre-docência: "Dono de festa é como chefe. (...) Tive que dar tudo.". A generosidade esperada do chefe, ou como bem destaca Perrone-Moisés, do casal-chefe, vê-se num grande desafio quando é necessário proceder da distribuição de bens, em especial do combustível (seja ele gasolina ou diesel) e das miçangas. A quantidade nunca será suficiente. Aliás, no momento de distribuição de miçangas, é preferível que algumas mulheres fiquem sem nada e outras com certa quantidade do que todas recebam uma quantidade ínfima.

Como apresentado, as arenas atuais de disputas políticas que os povos indígenas vêm a cada dia mais ocupando e marcando sua presença com pautas e reivindicações fortes, ainda mais num contexto político tenebroso como o atual, são marcadas pela presença de miçangas. É incontestável a presença de diferentes ornamentos delas feitos, seja em mobilizações nacionais como o Acampamento Terra Livre seja em ocasiões de âmbito mais local, como a 
visita de alguma autoridade numa aldeia indígena ${ }^{38}$. Seguindo a metáfora de Manuela Carneiro da Cunha, vê-se que os povos indígenas sempre "tiram de sua mala" algum adorno de miçanga nos momentos em que devem performar sua "cultura".

Também é comum que se refira a essas arenas atuais de disputa política como as guerras de hoje em dia, estendendo-se para formulações como "o arco e a flecha de hoje em dia são papel e caneta", e mesmo o reconhecimento de ferramentas jurídicas como Protocolos de Consulta como as ferramentas que devem ser utilizadas nos tempos atuais para enfrentar as pesadas batalhas que seguem aparecendo. Podemos dizer que é neste tipo de momento que os povos indígenas do Tumucumaque mais mobilizam as vestes que identificam como sendo aquelas suas tradicionais.

A quebra nas sequências de siwarapa - termo utilizado para designar as também chamadas "guerras intertribais" - e a ênfase no repertório de eremiton trazidas em seguida pelo pïyai, a partir dos cantos e danças que copiou de outros animais, demonstra uma oscilação no contínuo Festa-Guerra. Podemos perceber também que, nessas narrativas, o uso das miçangas intensifica-se neste segundo momento, em que a guerra muda de caráter. Temos, então, outra ênfase dada aos corpos em questão: a visibilidade que o uso das miçangas confere torna-se mais destacado do que seu peso, indesejado nas situações de guerras.

No pensamento ameríndio, tal como têm enfatizado diversas etnografias, a visão ocupa papel central. A proposta do perspectivismo ameríndio, apresentada por Viveiros de Castro e Tânia Stolze Lima destaca essa centralidade. Denise Fajardo Grupioni nos apresenta diversos exemplos em que podemos ver essa centralidade entre os Tarëno, como nos verbos traduzidos como aprender e ensinar (Grupioni 2009a) quanto em relação à palavra comumente traduzida por cacique, conforme anteriormente dito, pataentu. Esse sufixo -entu estaria ligado ao verbo olhar, ene,

É claro que essa relação entre saber e ver não se restringe aos Tiriyó. Um exemplo ainda na mesma região, é o caso descrito por Joana Cabral de Oliveira (2012) em que os pesquisadores wajãpi formulam que os karaiko, não-indígenas, detém conhecimentos

38 Um exemplo que pode ser acompanhado em vídeo é a visita de Michel Temer, em 2012, ainda vicepresidente da República, à base da Força Aérea Brasileira, localizada dentro da TI Parque do Tumucumaque, nas proximidades da aldeia Missão Tiriyó. Nessa ocasião, alguns dos principais caciques da região aguardaram pacientemente que houvesse um momento de reunião com o político, que apenas lhes dirigiu a palavra nos minutos finais de sua visita. Aventino Nakai Tiriyó Kaxuyana, atual presidente da APITIKATXI, registrou toda a visita em vídeo, que pode ser acessado no seguinte link: https://youtu.be/DgRmbZaPC8I (acessado em 25 de setembro de 2019). 
relativos a micróbios porque desenvolveram instrumentos capazes de vê-los: "Vocês sabem porque vocês viram!”. Ver e saber são ações intrinsecamente relacionadas.

Mas é evidente que não basta ver para saber. Como destacou Lurdes Kaxuyana, quando indaguei-lhe porque as velhas gostavam tanto de miçanga, "elas gostam porque elas sabem", denotando o quanto os conhecimentos estão ligados também à afetividade. No caso das velhas, retoma-se a centralidade da visão em relação ao saber quando elas lamentam estarem perdendo a visão, não conseguindo mais tecer miçangas como antes, dificultando inclusive que ensinem para suas netas o que sabem sobre miçangas e repertórios de grafismo.

Perder a visão e perder conhecimentos são ações que possuem, portanto, certa ligação. Como dito antes, não são relações obrigatórias: o canto, por exemplo, não depende de quão bem enxerga uma pessoa. Mas muitos dos conhecimentos tidos em alta conta pelos povos indígenas referem-se às habilidades manuais de tecelagem, em muito prejudicadas quando a visão da artesã ou do artesão se desgasta.

Também na tese de Denise Fajardo Grupioni, há uma interessante exegese linguística a respeito do verbo warë, traduzido como "conhecer/saber": “'estender a corda viva' para além de si mesma. Sendo essa 'corda viva', $w a$, associada à própria existência humana. Assim é que cada homem tarëno concebe-se, literalmente, como o 'pedaço de uma corda', que ao longo da vida (...) ‘amarra-se pelas mãos' (...) a outras cordas.” (sup cit.:185).

Tecer miçanga também parece ser especialmente adequado para sinalizar a condição humana. Ainda que outros seres sejam a elas relacionados, como o japu, as lagartas e eventuais animais que portam enfeites delas feitos, nenhum outro ser tece miçanga, nem mesmo todos os humanos o fazem. Os pajés não usariam miçangas porque os espíritos não gostam muito delas, e os espíritos não gostariam delas porque não são gente, conforme sugeriu a senhora Nazaré Tiriyó. Relacionar essa fala com a crescente entrada de miçangas promovidas pelos freis na Missão Tiriyós e a conversão dos indígenas ao cristianismo pode ser interessante, embora o episódio central pareça ser outro: a entrega de um cesto contendo seus kuri, espíritos, de Yonare para Protásio Frikel.

Como apresentado, é interessante notar que na imaginação das gerações mais jovens, ou não tão jovens assim, a figura do pajé é de alguém que usa muitas miçangas, alguém profusamente adornado com essas peças, embora as pessoas mais velhas, que viram de perto 
essas figuras, indiquem com absoluta certeza que os mesmos não utilizavam miçangas, mas apenas algodão.

Os contrastes mencionados pelos Tarëno entre maru (algodão) e samura (miçanga) enfatizam tanto a durabilidade do material (algodão se desfaz logo; já as miçangas não perecem) quanto a durabilidade das cores (o algodão tingido logo desbota; as miçangas valorizadas são aquelas que não perdem sua cor). O algodão é plantado nas roças, demora a ser feito, exige grandes quantidades da planta, além de muita disponibilidade do tempo. Já as miçangas vêm de fora, em quantidades grandes. O algodão quebra, a miçanga dura; o algodão desbota, a miçanga mantém a cor; para ter muito algodão, é preciso muito trabalho, as miçangas já vêm em grandes quantidade. Interessante notar que a madeira ideal para se fazer o tear de tecer keweyu é o galho do pé de algodão. Só as velhas sabem fazer fio de algodão, as novas sabem tecer motivos de miçangas desconhecidos pelas velhas.

A apreciação que os espíritos fazem dos fios de algodão é algo comum entre outros povos indígenas da Amazônia, como os Wajãpi (Gallois 1984; Kopenawa \& Albert 2014; Gongora 2017). Os elementos que costumam ser mobilizados nessas apreciações são a leveza e a extensão dos fios. É recorrente o entendimento de que são os fios de algodão que ligam os pajés e seus espíritos, bem como pessoas e seus duplos, ou mesmo que permitem a continuidade da vida entre as famílias.

Já o apreço das miçangas nos contextos políticos, não necessita mais uma vez ser reiterado. As características apreciadas nas miçangas que costumam ser destacadas, nesses casos, costumam ser sua profusão, sua beleza e o estabelecimento de relações necessárias para sua obtenção, além da habilidade técnica das mulheres que produzem esses adornos. As miçangas trazem elementos das relações pëeto e pawana: pëeto por sua produção cotidiana, por estabelecerem essa relação de cooperação entre pessoas; pawana pela sua exterioridade sempre presente e também bem quista.

Se as guerras antigas, das siwarapa, exigiam diversos cuidados corporais, como dietas e ornamentações com pinturas e adornos feitos de algodão, os conflitos políticos atuais impelem outros cuidados, que já não exigem a leveza como atributo fundamental, mas evidenciam principalmente a capacidade de estabelecer aliados ${ }^{39}$, sejam eles indígenas ou não,

39 Se enfocarmos os fios de algodão e sua relação com os espíritos, destacada acima, é possível considerar que em ambos os casos faz-se alusão a alianças, sendo que nas guerras antigas destacava-se as alianças com esses seres não-humanos, enquanto que nas guerras atuais, o fundamental seja evidenciar relações com parceiros não-indígenas que facilitem a aquisição das contas de vidro. 
como podemos ver pela grande circulação de peças que acontece entre os próprios povos indígenas. A conformação do "estilo regional" entre os povos indígenas do Amapá e do norte do Pará é um exemplo dessa situação. É essa visibilidade que marca os atuais contextos políticos, e é nela que apostam tanto povos indígenas. E não só bem enfeitados, portanto visíveis, aparecem esses corpos: eles também vêm em conjunto, entoando cantos e performando danças - eremi. Ou seja, as guerras atuais seguem mobilizando elementos relacionados às festas, evidenciando a centralidade dessa linguagem nos modos de ser ameríndios. 
"Considerações finais" - ou alguns arremates 
Os ornamentos de miçangas são compostos por dois materiais: miçangas e fios (de nylon ou de algodão), sendo que há uma grande distinção entre os materiais: enquanto as miçangas são apreciadas pela sua durabilidade (é um dos principais meios de distinguir as miçangas tchecas das chinesas, por exemplo), os fios, independentemente de seu material, são facilmente rompidos. Contudo, quanto mais bem trabalhada é a trama tecida com as miçangas, mais resistente fica o adorno - o que não significa que se deve tensionar em demasia o fio no momento de confecção da peça, visto que isso também a deixa frágil. Podemos dizer que existe uma tensão ideal que só é adquirida pela artesã com a prática, ao longo de sua vida. Esse é um dos motivos para as meninas iniciarem o aprendizado pela confecção dos fios de miçangas, que não exigem de imediato a habilidade de tensionar os fios, mas já possibilitam o desenvolvimento de certa intimidade entre a artesã e os materiais.

Além da habilidade manual no tensionamento dos fios no momento de tecelagem dos adornos, também é necessário que se tenha calma e disposição para a elaboração desses objetos. Lembro de um dia em que uma mulher katxuyana estava me ensinando a tecer um bracelete, na aldeia Santidade, mesmo após um dia muito longo e exaustivo de trabalho. Eu perguntava a ela se ela estava cansada, mas ela só se disse cansada quando terminou de tecer o bracelete. A concentração exigida para não se confundir no momento de escolha das cores que compõem os grafismos também é central, afinal a trama é sempre a mesma, sendo os desenhos compostos pelas cores específicas das miçangas que são sendo escolhidas enquanto se tece, conforme explicitarei adiante. Pude reparar também que os erros na escolha das cores não são tolerados por essas mulheres, sendo que mesmo aqueles que são reparados tardiamente exigem o desmontar de todo o trabalho para que seja colocada a cor adequada, mesmo que para uma única miçanga ${ }^{40}$.

Esse empenho resoluto por parte das mulheres na produção de adornos que são fundamentais para a composição de um corpo belo e adequado ${ }^{41}$, remete ao empenho direcionado à manutenção da aldeia como um bom local de moradia. $\mathrm{O}$ afinco na busca e na manutenção do tensionamento ideal das peças de miçangas encontra paralelo com aquele que se procura produzir no cotidiano da vida na aldeia: tensionar demais o fio de uma peça de miçanga pode fazer com que o mesmo arrebente, da mesma forma que a tensão exagerada

40 Destoando dessa rigidez há o fato curioso, destacado no Capítulo 2, de todo bracelete ou colar possuir um pequeno detalhe que faça com que a repetição do desenho não seja completamente simétrica. Isso parece remeter ao princípio da diferença que Lévi-Strauss identifica nos mitos ameríndios (Lévi-Strauss, 1991 [2014]; Perrone-Moisés 2006).

41 Evidente que a produção de adornos corporais não é a única atividade implicada na produção de corpos, que inclui, por exemplo, a alimentação, a ingestão de bebidas, danças etc. 
entre os moradores de uma aldeia pode fazer com que aconteçam cisões; uma peça de miçanga com a trama frouxa fica disforme, tal como laços sociais demasiadamente soltos não chegam a configurar um local de moradia.

Em outras palavras, vemos que cultivar a durabilidade no tempo não depende apenas de materiais resistentes (como miçangas ou parentes consanguíneos): certa tensão é necessária para que não se afrouxem demasiados os laços, sejam os sociais ou aqueles de um bracelete. Mas, assim como as miçangas de determinado ornamento desmanchado configuram novas peças, também as pessoas se realocam em novos locais de moradia, fazendo novas alianças no decorrer de suas histórias.

Conforme apresentado ao longo da dissertação e demonstrado por diversas autoras, como Gallois (2002), Lúcia Van Velthem (2003) e Grupioni (2009), a beleza para os povos indígenas do sudeste guianense é marcada pelo perigo. Os seres mais temidos por esses povos são, assim, aqueles que definitivamente ostentam seus adornos e pinturas, tais como a sucuri e a onça pintada. Para os Wayana, por exemplo, todos os motivos de pinturas corporais foram tirados da pele da sucuri (Van Velthem, 2003). A humanidade, por outro lado, possui uma pele sem pinturas, sobre a qual é possível incorrer modificações, mas atentando para o risco de uma transformação completa - possível, visto todos os seres compartilharem um fundo de humanidade, sobre o qual ostentam diversas roupas diferentes (Grupioni 2009b; Lévi-Strauss 2014; Viveiros de Castro 2002).

As miçangas, apreciadas há séculos, são eminentemente estrangeiras - o que não impede as mulheres tiriyó de considerarem que a tecelagem com miçangas é mais antiga do que aquela feita com sementes (Grupioni, 2008:12). Isso, por si só, já nos remete àquilo acima exposto, da origem da beleza no Outro, e da relação entre beleza e perigo (Van Velthem 2003). Não à toa, as miçangas são enfeites ditos muito apreciados pelos espíritos por conta de seu brilho e durabilidade, fazendo com que a pessoa que muito se enfeita com miçangas esteja especialmente visível a certos seres, em especial quando seus adornos são conferidos de padrões gráficos específicos.

A durabilidade e a beleza das miçangas entremeiam-se enormemente quando se trata de processos de fabricação do corpo (Seeger et allii 1979). É o caso, por exemplo, dos apertados fios de miçangas que são amarrados nos tornozelos, coxas, pulsos e braços dos bebês, para que esses tenham seus braços e pernas destacados e fortes (lembrando a relação entre miçangas e dentes para os Kaxinawa, apontada por Lagrou 2007, 2016). Além disso, 
Chapuis nota que, para os Kalina, 'os bons espíritos são sensíveis a tudo que seja ornamento' (Chapuis, 1988:568).

Esses pontos que fazem da beleza algo apreciado e almejado, ainda que também temido, remetem às narrativas míticas. Em seus mitos referentes ao conhecimento do repertório de padrões gráficos, é a partir de encontros com diversos Outros que emergem esses motivos. Encontros esses que nem sempre são pacíficos, resultando em guerras, como é o caso do mito que relacionada a origem dos padrões gráficos wayana e aparai a uma série de encontros fatídicos de guerreiros desses povos com uma sucuri sobrenatural, o Tuluperê (Van Velthem 1998).

Outra implicação do uso excessivo de elementos de apreciação estética liga-se à profusão com que são encontradas as miçangas. Chapuis (1988: 422-423), coloca que os cuidados com o corpo, de certa forma, orientam-se sempre em direção a uma certa eternidade, estando, no caso wayana, a ornamentação diretamente relacionada à juventude. Assim sendo, mostrar-se com aparência jovem, a despeito do evidente envelhecimento humano, indica também o perigo do abandono da condição humana (marcada pela perecibilidade ${ }^{42}$ ).

Organizar o fluxo contínuo de eventos por meio de uma agulha que pincela cores específicas, ordenando-se num fio, de modo a remeter a eventos anteriores (laçadas nas miçangas das fileiras anteriores - conexões que criam a trama): eis o que fazem as artesãs tiriyó ao tecerem seus belos e perigosos ornamentos de miçangas. Espero ter demonstrado que, para esses povos indígenas, há grande importância e cuidado na elaboração de um cotidiano frugal, mas que sempre está apontando para a exuberância dos momentos de festa, tão estimados quanto possivelmente perigosos, onde há abundância de comida, bebida, música e ornamentos.

Voltamos aqui ao que nos dizia Pierre Clastres, ao propor o desafio de uma análise positiva das organizações sociais nas Terras Baixas da América do Sul. Ao invés de sociedades sem Estado e sem História, sociedades contra o Estado e contra a possibilidade de uma História que tente fixar suas diferentes gentes sob um ou outro etnônimo, ou que congele seus repertórios gráficos em determinado conjunto fechado (Coelho de Souza 2012; Gallois 2012). Como coloca Lagrou (2011), sociedades que elaboram também uma arte contra o Estado.

42 A respeito da gênese da humanidade segundo a mitologia wayana, há o artigo de Lúcia Van Velthem (2009), que conta como após diversas tentativas frustradas com materiais inadequados, a humanidade foi feita a partir do arumã, sendo, por conta disso, perecível, embora também maleável. 
A arte em miçangas produzida pelas mulheres tiriyó, katxuyana, wayana, aparai, também traz a reflexão a respeito dos modos como as estruturas locais fazem das contingências históricas (como o intercâmbio de bens industrializados) parte intrínseca delas mesmas, imprimindo, no que a princípio seria estrangeiro, marcas que compartilham e disputam aspectos materiais e imateriais do mundo.

No contexto político atual de perseguição atroz contra os povos indígenas e a floresta (dentre tantos outros alvos), espero que este trabalho tenha trazido à tona reflexões que fazem eco à capacidade inerente à disciplina antropológica de questionar e enfrentar o que se estabelece como modelo (Viveiros de Castro 2015).

A pesquisa realizada abriu, mais do que fechou, caminhos. Chegando aos momentos finais dessa dissertação de mestrado - pelos motivos pragmáticos dos quais não se escapa - a elaboração de "Considerações Finais" soa algo deslocada. Tal com outros estudos antropológicos recentemente realizados na região (Paula 2015, Braga 2017), o que ressalta é a persistência de certos temas considerados clássicos na etnologia indígena das Terras Baixas da América do Sul, como a centralidade da corporalidade (Seeger et allii 1979) e da lógica das qualidades sensíveis (Lévi-Strauss 1966), além da abertura para o Outro como constitutiva dos modos de pensar ameríndios (Lévi-Strauss 1991) e da presença de características de uma sociedade contra o Estado (Clastres 1974). Também podemos incluir a consonância com as proposições de redes de relações que superam recortes geográficos e étnicos na região (Gallois 2005, 2017).

Encontrar ressonâncias desses temas clássicos da etnologia indígena numa etnografia contemporânea atesta tanto as continuidades que as hipóteses desses autores têm no presente quanto possibilita descrevê-las nas situações atuais, onde esses povos indígenas têm acesso a tecnologias como smartphones e aplicativos de compartilhamento de arquivos, além de participarem de encontros políticos com a presença de povos indígenas de origens diversas, bem como se veem frente a políticas públicas que exigem a elaboração de identidades étnicas que funcionam numa lógica outra que a indígena.

Assim, a pesquisa que resultou nesta dissertação procurou verificar o que as miçangas “fazem fazer", como sugere Latour (2002), entre os povos indígenas do sudeste guianense. O que encontramos é que, ao longo de mais de três séculos e meio, as miçangas mobilizam a tessitura de relações com diferentes parceiros de trocas, bem como a produção de corpos 
(humanos e não humanos), a generosidade necessário ao chefe, o destaque para a composição com as diferenças e a importância da circulação de conhecimentos.

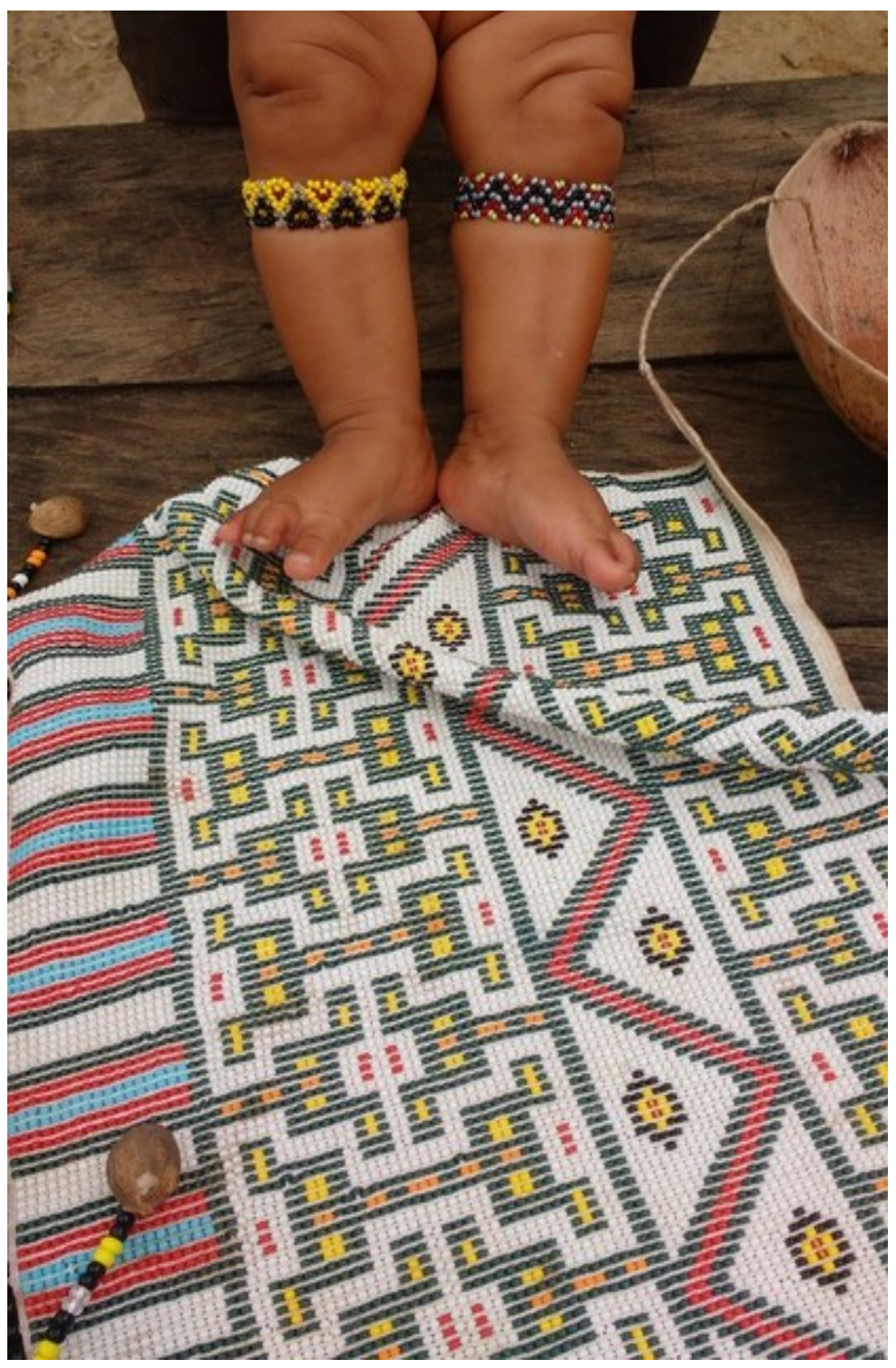

Figura 54: Miçangas na perna de uma bebê e keweyu. Aldeia Pedra da Onça. Março 2017. 


\section{BIBLIOGRAFIA}

ALBERT, Bruce; RAMOS, Alcida Rita. Pacificando o branco: Cosmologias do contato no norte-Amazonico. São Paulo: Editora UNESP/Impres Oficial do Estado, 2002. Disponível em: <http://books.openedition.org/irdeditions/24689>. Acesso em: 30 set. 2019.

APINA, APIWATA, AWATAC. Wajãpi kõ omõsãtamy wayvu oposikoa romõ ma'ë. Protocolo de Consulta e Consentimento Wajãpi. 2014.

APITIKATXI; APIWA; IEPÉ. Plano de Gestão Territorial e Ambiental das Terras Indígenas Parque do Tumucumaque e Rio Paru d'Este. São Paulo: Iepé, 2018.

BARBOSA, Gabriel Coutinho. Das Trocas de Bens. In: GALLOIS, Dominique Tilkin (Org.). Redes de Relações nas Guianas. São Paulo: Humanitas/Fapesp, 2005.

BARBOSA, Gabriel Coutinho. Festas, guerras e trocas entre os Aparai e Wayana meridionais. Revista de Antropologia, v. 54, n. 2, p. 829-855, 2011.

BARBOSA, Gabriel Coutinho. Formas de intercâmbio, circulação de bens e a (re)produção das redes de relações aparai e wayana. Dissertação de Mestrado, PPGAS/USP, São Paulo, 2002.

BARBOSA, Gabriel Coutinho. Os Aparai, os Wayana e suas redes de intercâmbio. Tese de Doutoramento em Antropologia Social, PPGAS/USP, São Paulo, 2007.

BARCELOS NETO, Aristóteles. Apapaatai. Rituais de máscaras no Alto Xingu. São Paulo: Edusp, 2008.

BELAUNDE, Luísa Elvira. Chaquiras Shipibo-konibo. In: LAGROU, ELSJE (Org.). No caminho da miçanga: um mundo que se faz de contas. Rio de Janeiro: Museu do Índio/Funai, 2016, p. 92-99.

BLAIR, Elliot H.; PENDLETON, Lorran S. A.; FRANCIS JR., Peter J. The Beads of St. Catherine's Island. New York: Anthropological Papers of The American Museum of Natural History, 2009. (The Archaeology of Mission Santa Catalina de Guale, 5).

BOAS, Franz. Arte Primitiva. [s.1.]: Vozes, 2014. Disponível em: $<$ https://www.estantevirtual.com.br/iluminacoes/franz-boas-arte-primitiva-1924567822>.

Acesso em: 13 out. 2019.

BRAGA, Leonardo Viana. Panil'em: um esboço sobre os modos de saber entre os Zol'é. text, Universidade de São Paulo, 2016. Disponível em:

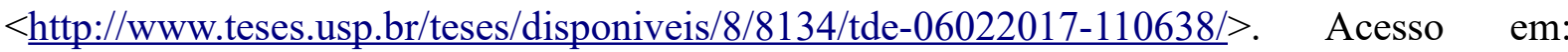
15 out. 2019.

BRIGHTMAN, M. A. Amerindian Leadership in Guianese Amazonia. Doctoral, University of Cambridge, 2007. Disponível em: <http://discovery.ucl.ac.uk/1521454/>. Acesso em: 13 out. 2019. 
BUCHILlET, Dominique. Contas de vidro, enfeites de branco e "potes de malária": epidemiologia e representações de doenças infecciosas entre os Desana do Alto Rio Negro. In: ALBERT, Bruce; RAMOS, ALCIDA RITA (Orgs.). Pacidicando o Branco: Cosmologias do contato no norte amazônico. São Paulo: Editora UNESP/Impres Oficial do Estado, 2002.

CABRAL DE OLIVEIRA, Joana. "Vocês sabem porque vocês viram!": reflexão sobre modos de autoridade do conhecimento. Revista de Antropologia, v. 55, p. 51-74, 2012.

CABRAL, Mariana Petry. Juntando cacos: uma reflexão sobre a classificação da Fase Koriabo no Amapá. Amazônica - Revista de Antropologia, v. 3, n. 1, 2011. Disponível em: $<$ https://periodicos.ufpa.br/index.php/amazonica/article/view/632>. Acesso em: 30 set. 2019.

CALADO, Manuel. Os encantados transformados por Manákamã ou Arqueoastronomia na Savana Tiriyó (Serra do Tumucumaque). In: BELTRÃO, Jane; MASTOP-LIMA, Luísa (Eds.). Matemáticas. No Plural! Sistemas matemáticos indígenas e sistemas de aferição. Belém: UFPA, 2009.

CALADO, Manuel. Tïhtakariwaïn: um santuário rupestre no Tumucumaque brasileiro. Disponível $\quad \mathrm{em}: \quad<$ https://www.academia.edu/11772806/T\%C3\%AFhtakariwa $\% \mathrm{C} 3 \% \mathrm{AFn}$ um santu $\% \mathrm{C} 3 \% \mathrm{~A} 1$ rio rupestre no Tumucumaque brasileiro $>$. Acesso em: 13 out. 2019.

CARNEIRO DA CUNHA, Manuela. "Cultura" e cultura: conhecimentos tradicionais e direitos intelectuais. In: Cultura com aspas. [s.1.]: Cosac Naify, 2009, p. 311-373.

CASTRO, Eduardo Viveiros de. A floresta de cristal: notas sobre a ontologia dos espíritos amazônicos. Cadernos de Campo (São Paulo, 1991), v. 15, n. 14-15, p. 319, 2006.

CASTRO, Eduardo Viveiros de. Metafísicas Canibais. Edição: $1^{\text {a }}$. São Paulo, SP: Cosac \& Naify, 2015.

CHAPUIS, Jean. La Personne Wayana entre sang et ciel. Chicoutimi: J.-M. Tremblay, $1998 . \quad$ Disponível em: $<$ http://classiques.uqac.ca/contemporains/chapuis_jean/personne_wayana_entre_sang_et_ciel/ personne wayana.html> . Acesso em: 13 out. 2019.

CLASTRES, Pierre. A sociedade contra o Estado. São Paulo: Cosac \& Naify, 2003.

COELHO DE SOUZA, Marcela Stockler. A pintura esquecida e o desenho roubado: contrato, troca e criatividade entre os Kisêdjê. Revista de Antropologia, v. 55, n. 1, 2012. Disponível em: <http://www.revistas.usp.br/ra/article/view/46965 >. Acesso em: 15 out. 2019.

CREVAUX, Docteur J. Voyages dans l' Amérique du Sud. Revised Second Edition edition. [s.1.]: Librairie Hachette et Cie., 1883.

CUNHA, Manuela Carneiro da. Cultura com Aspas e Outros Ensaios - Coleção Ensaios. Edição: $1^{\text {a }}$. São Paulo, SP: Cosac \& Naify, 2009. 
DÉLÉAGE, Pierre. Les répertoires graphiques amazoniens. Journal de la société des américanistes, v. 92, n. 93-1, p. 97-126, 2007.

DEMARCHI, André. ARMADILHAS, QUIMERAS E CAMINHOS: TRÊS ABORDAGENS DA ARTE NA ANTROPOlOGIA CONTEMPORÂNEA. Espaço Ameríndio, v. 3, n. 2, p. 177, 2009.

DREYFUS, Simone. Os empreendimentos coloniais e os espaços políticos indígenas no interior da Guiana Ocidental de 1613 a 1796 . In: VIVEIROS DE CASTRO, Eduardo; CARNEIRO DA CUNHA, Manuela (Eds.). Amazônia: Etnologia e história indígena. São Paulo: NHII-USP/FAPESP, 1993, p. 19-41.

DUBIN, Lois Sherr. The History of Beads: From 30,000 B.C. to the Present. New York: Harry N. Abrams, 1987.

EWART, Elizabeth (Org.). Body arts and modernity. Wantage: Sean Kingston Publishing, 2007.

EWART, Elizabeth. Black paint, red paint and a wristwatch: the aesthetics of modernity among the Panará in Central Brazil. In: EWART, Elizabeth (Org.). Body arts and modernity. Wantage: Sean Kingston Publishing, 2007.

FRIKEL, Margarete Pfister-Burkhalter, Christian F. Feest Protasio. Os Tiriyo. Seu sistema adaptativo. Volkerkundliche Abhandlungen. Band V. [s.1.]: Kommissionsverlag Munstermann-Druck, 1973.

FRIKEL, Protasio and Roberto Cortez. Elementos demograficos do Alto Paru de Oeste, Tumucumaque Brasileiro. First edition. [s.1.]: Publicaçoes Avulsas do Museo Goeldi, 1972.

FRIKEL, Protásio. Classificação lingüistico-etnologia das tribos indígenas do Pará setentrional e zonas adjacentes. Revista de Antropologia, v. 6, n. 2, p. 113, 1958.

FRIKEL, Protásio. Dez anos de aculturação Tiriyó: 1960-70. 1971. Disponível em: $<$ http://repositorio.museu-goeldi.br:8080/jspui/handle/mgoeldi/895 $>$. Acesso em: 30 set. 2019.

FRIKEL, Protásio. Os últimos Kahyana. Revista do Instituto de Estudos Brasileiros, v. 1, p. 7-34, 1966.

GALlOIS, Dominique Tilkin (Org.). Redes de Relações nas Guianas. São Paulo: Humanitas/Fapesp, 2005.

GALLOIS, Dominique Tilkin. "Cultura", modos de existência e corporalidades indígenas Práticas Wajãpi, Guarani-Kaiowá, Yek’wana e Kaiapó no Brasil. Dossier spécial (Ariel de Vidas \& Hirtzel, eds), no prelo, 2017. 
GALLOIS, Dominique Tilkin. Donos, Detendores e Usuários Da Arte Gráfica Kusiwa. Revista de Antropologia, v. 55, n. 1, 2012. Disponível em: $<$ http://www.revistas.usp.br/ra/article/view/46956 >. Acesso em: 1 out. 2019.

GALLOIS, Dominique Tilkin Gallois. Kusiwa: pintura corporal e arte gráfica wajãpi. Rio de Janeiro: Museu do Índio-Funai/APINA/CTI/NHII-USP, 2002.

GALLOIS, Dominique Tilkin. Materializando saberes imateriais: experiências indígenas na Amazônia Orienta. Revista de Estudos e Pesquisas, FUNAI, v. 4, n. 2, p. 95-116, 2007.

GALlOIS, Dominique Tilkin. Movimento na Cosmologia Wajãpi. Criação, Expansão e Transformação do Universo. Tese de Doutoramento em Antropologia Social, FFLCH/USP, São Paulo, 1988.

GALlOIS, Dominique Tilkin. Povos Indígenas no Brasil: Amapá/Norte do Pará. São Paulo: CEDI, 1983.

GALLOIS, Dominique Tilkin. Relatório Final de Pesquisa e Documentação da Arte Gráfica Kusiwa. Sociedade dos Amigos do Museu do Índio - SAMI /IPHAN, convenio n. 791063. São Paulo. [s.1.: s.n.], 2015.

GALLOIS, Dominique. O pajé wajãpi e seus “espelhos”. Revista de Antropologia, v. 27/28, p. 179-196, 1984.

GELL, Alfred. A rede de Vogel, armadilhas como obras de arte e obras de arte como armadilhas. Arte e Ensaios, v. 8, n. 8, p. 174-191, 2001.

GELL, Alfred. Arte e Agência. Trad. Jamille Pinheiro Dias. São Paulo: Ubu, 1998. Disponível em: $\quad$ https://www.travessa.com.br/arte-e-agencia/artigo/53d0aa0f-f776-4baca0a6-2afe5a87d4a9>. Acesso em: 13 out. 2019.

GELL, Alfred. The technology of enchantment and the enchantment of technology. In: COOTE, J.; SHElton, A. (Orgs.). Anthropology, Art and Aesthetics. Oxford: Clarendon Press, 1992.

GONGORA, Majoí Fávero. Ääma ashichaato - replicações, transformações, pessoas e cantos entre os Ye'kwana do rio Auaris. Tese de Doutoramento em Antropologia Social, PPGAS/USP, São Paulo, 2017.

GOW, Peter. Of Mixed Blood: Kinship and History in Peruvian Amazonia. 1 edition. Oxford England : New York: Clarendon Press, 1991.

GRAY, Malinda Joy. Beads: Symbols of Indigenous Cultural Resilience and Value. Master of Arts, Department of Anthropology, University of Toronto, Toronto, 2017.

GRUPIONI, Denise Fajardo. The Guianese Paradox. In: WHITEHEAD, Neil L.; ALEMÁN, Stephanie W. (Eds.). Anthropologies of Guayana - Cultural Spaces in Northeastern Amazonia. Tucson: The University of Arizona Press, 2009, p. 102-112. 
GRUPIONI, Denise Fajardo; ANDRADE, Lúcia M. M. de (Orgs.). Entre Águas Bravas e Mansas. São Paulo: CPI-SP e Iepé, 2015. Disponível em:

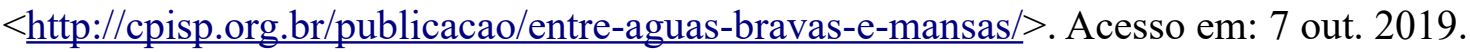

GRUPIONI, Denise Fajardo; OLIVEIRA, Cecília de Santarém Azevedo de. Corporalidades e saberes que informam concepções ameríndias de "gente". In: Coletânea Redes Ameríndias. São Paulo: [s.n.], 2012.

GRUPIONI, Denise Fajardo; TIRIYÓ, Diakui Sora; KAXUYANA TIRIYÓ, Cristiane Mitore. Artesãs do Maramara. Macapá: IPHAN/Iepé, 2007.

GRUPIONI, Denise Fajardo. Arte Visual Tiriyó e Kaxuyana: padrões de uma estética ameríndia. São Paulo: Iepé, 2009.

GRUPIONI, Denise Fajardo. Relatório de Oficina de Documentação de Saberes Associados à Tecelagem com Sementes e Miçangas das mulheres tiriyó e kaxuyana. 2008.

GRUPIONI, Denise Fajardo. Sistema e mundo da vida tarëno: um "Jardim de veredas que se bifurcam" na paisagem guianesa. Tese de Doutoramento em Antropologia Social, PPGAS/USP, São Paulo, 2002.

GRUPIONI, Denise Fajardo. Tempo e espaço na Guiana Indígena. In: GALLOIS, Dominique Tilkin (Org.). Redes de Relações nas Guianas. São Paulo: Humanitas/Fapesp, 2005.

GRUPIONI, Denise Fajardo. Tiriyó/Katxuyana: os fios, as contas e as gotas. In: LAGROU, ELSJE (Org.). Catálogo da Exposição No Caminho da Miçanga: um mundo que se faz de contas. Rio de Janeiro: Museu do Índio/Funai, 2016, p. 185-194.

HOWARD, Catherine. Pawana: a farsa dos visitantes entre os Waiwai da Amazônia setentrional. In: VIVEIROS DE CASTRO, Eduardo; CUNHA, Manuela Carneiro da (Orgs.). Amazônia: Etnologia e História Indígena. Sâo Paulo: NHII-USP/FAPESP, 1993.

IEPÉ; CPI-SP. Dossiê Terra Indígena Kaxuyana-Tunayana. 2018.

IEPÉ; CPI-SP. Dossiê Terra Indígenas Katxuyana-Tunayana. A demanda da TI KatxuyanaTunayana. 2013.

IPHAN, Instituto do Patrimônio Histórico e Artístico Nacional. Arte Kusiwa : pintura corporal e arte gráfica Wajãpi. --. Brasília, DF: Instituto do Patrimônio Histórico e Artístico Nacional. IPHAN, 2008.

JACOME, Camila Pereira. Dos Waiwai aos Pooco - Fragmentos de história e arqueologia das gentes dos rios Mapuera (Mawtohrî), Cachorro (Katxuru) e Trombetas (Kahu). Doutorado em Arqueologia, Universidade de São Paulo, São Paulo, 2017. Disponível em:

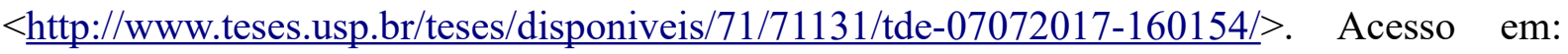
13 out. 2019. 
JÁCOME, Camila. Pelo rio Mapuera - Reflexões sobre arqueologia e etnologia indígena na Amazônia e Guiana. Universidade Federal de Minas Gerais, Belo Horizonte, 2011.

KARADIMAS, Dimitri. Casse-tête caribe, jeu d'images: Analyses iconographiques des motifs des massues circum-caribes, des ciel-de-cases wayana et des vanneries yekuana. L'Homme, n. 214, p. 37-74, 2015.

KARKLINS, Karlis; SPRAGUE, Roderick. Glass Trade in North America: an annotated bibliography. New York: Springer New York, 1972.

KIEFFER-DØSSING, Astrid. Re-assembling the Katxuyana collections: An analysis of past, present and possible futures of the Katxuyana collections as assemblages. Dissertação de Mestrado, Aarhus Universitet, 2016.

KLEIN, Tatiane Maíra. Práticas midiáticas e redes de relação entre os Kaiowá e Guarani em Mato Grosso do... Dissertação de Mestrado em Antropologia Social, PPGAS/USP, São Paulo, 2013. Disponível em: <http://www.teses.usp.br/teses/disponiveis/8/8134/tde14012014-121443/pt-br.php>. Acesso em: 1 out. 2019.

KOPENAWA, Davi; ALBERT, Bruce. La chute du ciel: Paroles d'un chaman yanomami. Paris: Pocket, 2014.

LA MOUSSE, Jean de; COLLOMB, Gérard. Les indiens de la Sinnamary: journal du père Jean de La Mousse en Guyane, 1684-1691. Paris: Chandeigne, 2006. (Collection Magellane).

LAGROU, Els. Existiria uma arte das sociedades contra o Estado? Revista de Antropologia,

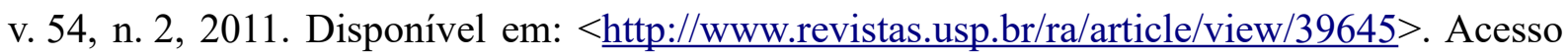
em: 13 out. 2019.

LAGROU, Els. Fluidez da Forma: arte, alteridade e agência em uma sociedade amazônica (Kaxinawa, Acre). Rio de Janeiro: Topbooks/PPGAS-UFRJ/CAPES, 2007.

LAGROU, Elsje (Org.). Catálogo da Exposição No Caminho da miçanga: um mundo que se faz de contas. Rio de Janeiro: Museu do Índio/Funai, 2016.

LAGROU, ELSJE. Existiria uma arte das sociedades contra o Estado? Revista de Antropologia, $\quad$ v. 54, $2011.2, \quad$ D. 2 Disponível $<$ http://www.revistas.usp.br/ra/article/view/39645 $>$.

LAINEY, Jonathan. Les colliers de wampum comme suport mémoriel : le cas du Two-Dog Wampum. In: BEAULIEU, Alain; GERVAIS, Stéphain; PAPILLON, Martin (Orgs.). Les Autochtones et le Québec: Des Premiers Contacts au Plan Nord. Montreal: Presses de l'Université de Montréal, 2013. Disponível em: < $\underline{\text { http://books.openedition.org/pum/5635>. }}$ Acesso em: 30 set. 2019.

LATOUR, Bruno. O que é iconoclash? Ou, há um mundo além das guerras de imagem? Horizontes Antropológicos, v. 14, n. 29, p. 0-0, 2008. 
LATOUR, Bruno. Reflexao Sobre O Culto Moderno Dos Deuses Fe( I )Tiches. Bauru: EDUSC, 2002.

LÉVI-STRAUSS, Claude. Histoire de Lynx. Paris: Plon, 1991.

LÉVI-STRAUSS, Claude. La pensée sauvage. Revised. Paris: Pocket, 1990.

LEVI-STRAUSS, Claude. Nous sommes tous des cannibales. Paris: Le Seuil, 2013.

LÉVI-STRAUSS, Claude. Tristes Trópicos. [s.1.]: Companhia das Letras, 1955.

LOWIE, Robert Harry. Lowie's Selected Papers in Anthropology. [s.1.]: Forgotten Books, 2017.

LUCAS, Maria Luísa. Antes a gente tinha vindo do Jabuti. Notas etnográficas sobre algumas transformações entre os Hixkariyana no rio Nhamundá/AM. Dissertação de Mestrado, Museu Nacional/ Universidade Federal do Rio de Janeiro, Rio de Janeiro, 2014.

MAKAR, A. B.; MCMARTIN, K. E.; PALESE, M.; et al. Formate assay in body fluids: application in methanol poisoning. Biochemical Medicine, v. 13, n. 2, p. 117-126, 1975.

MARUBO, Varin Mena. A desconfiança da miçanga: os Txakiri dos Marubo. In: LAGROU, Elsje (Org.). Catálogo da Exposição No Caminho da Miçangas: um mundo que se faz de contas. Rio de Janeiro: Museu do Índio/Funai, 2016, p. 100-104.

MEIRA, Sérgio. Orações relativas em línguas karib. Boletim do Museu Paraense Emílio Goeldi, v. 2, n. 1, p. 105-121, 2006.

MILLER, Joana. As coisas: enfeites corporais e a noção de pessoa entre os Mamaindê (Nambiquara). Tese de Doutoramento em Antropologia Social, PPGAS/Museu Nacional/UFRJ, Rio de Janeiro, 2007.

MORIM, Ana Gabriela. Krahô: a miçanga no universo mítico, ritual e cotidiano dos mẽhĩ. In: Catálogo da Exposição No Caminho da Miçanga: um mundo que se faz de contas. Rio de Janeiro: Museu do Índio/Funai, 2016, p. 137-164.

NOËL, Michael. Art décoratif et vestimentaire des Amérindiens du Québec: XVIe et XVIIe siècles. Montréal: Leméac, 1979.

OLIVEIRA, Joana Cabral de. "Vocês sabem porque vocês viram!": reflexão sobre modos de autoridade do conhecimento. Revista de Antropologia, v. 55, n. 1, 2012.

PAULA, Camila Galan de. Num mundo de muitos corpos: um estudos sobre objetos e vestimentas entre os Wajãpi no Amapá. text, Universidade de São Paulo, 2015. Disponível em: <http://www.teses.usp.br/teses/disponiveis/8/8134/tde-11032016-140934/>. Acesso em: 15 out. 2019. 
PERRONE-MOISÉS, Beatriz. Bons chefes, maus chefes, chefões: elementos de filosofia política ameríndia. Revista de Antropologia, v. 54, n. 2, p. 857-883, 2011.

PERRONE-MOISÉS, Beatriz. Festa e Guerra. Livre-Docência, Universidade de São Paulo, São Paulo, 2015.

PERRONE-MOISÉS, Beatriz. Mitos ameríndios e o princípio da diferença. In: NOVAES, A. (Org.). Oito visões da América Latina. São Paulo: Senac, 2006, p. 241-257. Disponível em:

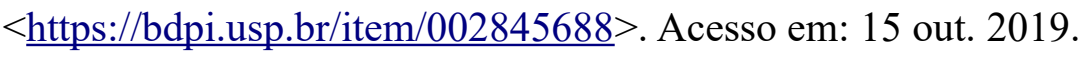

QUEIRÓZ, Ruben Caixeta de; GIRARDI, Luísa Gonçalves. Dispersão e Concentração Indígena nas Fronteiras das Guianas: análise do caso kaxuyana. Revista Brasileira do Caribe, v. XIII, n. 25, p. 15-42, 2012.

RENAULT-LESCURE, Odile. As palavras e as coisas do contato: Os neologismos Kali'na (Guiana Francesa). In: ALBERT, Bruce; RAMOS, Alcida Rita (Eds.). Pacificando o branco: Cosmologias do contato no norte-Amazonico. Marseille: IRD Éditions, 2018, p. 85-112. (D’Amérique latine). Disponível em: <http://books.openedition.org/irdeditions/24737>. Acesso em: 1 out. 2019.

RIBEIRO, Berta G. Dicionario Do Artesanato Indigena. [s.1.]: Itatiaia, 1988.

RIVIÈRE, Peter; GRUPIONI, Denise Fajardo; GALlOIS, Dominique Tilkin; et al. A propósito de Redes de relações nas Guianas. Mana, v. 13, n. 1, p. 251-273, 2007.

RIVIĖRE, Peter. An ethnographic survey of the indians on the divide of the guianese and amazonian river systems. Tese de Doutoramento, University of Oxford, Oxford, 1963.

RIVIERE, Peter. Individual and Society in Guiana: A Comparative Study of Amerindian Social Organisation. First Edition. Cambridge Cambridgeshire; New York: Cambridge University Press, 1984.

RIVIÈRE, Peter. Marriage among the Trio: a principle of social organisation. Oxford: Clarendon P, 1969.

SCHOEPF, Daniel. Le japu faiseur de perles: Un mythe des Indiens Wayana Aparai du Bresil. [s.1.]: Musee d'Ethnographie, 1976.

SEEGER, Anthony; DA MATTA, Roberto; VIVEIROS DE CASTRO, Eduardo. A construção da pessoa nas sociedades indígenas brasileiras. Boletim do Museu Nacional, n. 32, p. 2-19, 1979.

SILVA, Victor Alcantara e. Vestígios do rio Turuni: perseguindo fragmentos de uma história Txikyana. text, Universidade de São Paulo, 2016. Disponível em:

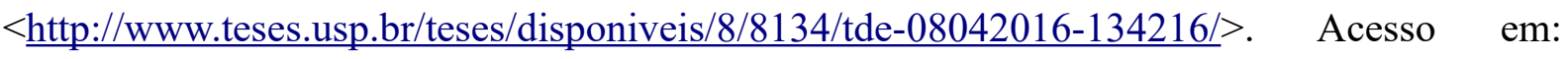
13 out. 2019. 
STENGERS, Isabelle. Cosmopolitiques 1: La guerre des sciences, L'invention de la mécanique : pouvoir et raison, Thermodynamique : la réalité physique en crise. POCHE SC.HUMAINES \& SOCIALES edition. Paris: Editions La Découverte, 2003.

SZTUTMAN, Renato. Metamorfoses do Contra-Estado. Pierre Clastres e as Políticas Ameríndias. Ponto Urbe. Revista do núcleo de antropologia urbana da USP, n. 13, 2013.

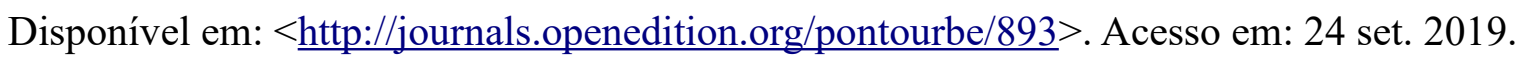

TARDE, Gabriel. Monadologia e sociologia: e Outros Ensaios. São Paulo: Cosac \& Naify, 2007.

VAN VELTHEM, Lúcia Hussak; LINKE, Iori. da Arte Gráfica Wayana e Aparai. [s.1.]: Museu do Índio - Funai/ Iepé, 2010. Disponível em: $<$ https://www.academia.edu/35514408/LIVRO DA_ARTE_GRAFICA WAYANA E APAR

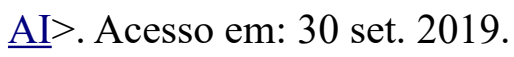

VAN VELTHEM, Lúcia Hussak. A Pele de Tuluperê. Uma etnografia dos trançado dos Wayana. Belém: Museu Paraense Emilio Goeldi, 1998. Disponível em: $<\underline{\text { https://www.museu- }}$ goeldi.br/assuntos/publicacao/catalogo-de-publicacoes/a-pele-de-tulupere-uma-etnografiados-trancado-dos-wayana-1>. Acesso em: 25 set. 2019.

VAN VELTHEM, Lucia Hussak: Des perles de verre: deux mondes em interaction. In: Gruzinski, Serge (org.): Planète Métisse. Paris: Musèe Du Quai Branly/Actes Sud, pp. 50-55, 2008.

VAN VELTHEM, Lúcia Hussak. Mulheres de cera, argila e arumã: princípios criativos e fabricação material entre os Wayana. Mana, v. 15, n. 1, p. 213-236, 2009.

VAN VELTHEM, Lúcia Hussak. O Belo é a Fera - a estética da predação e da produção entre os Wayana. Lisboa: Museu Nacional de Etnologia Assirio \& Alvim, 2003. Disponível em: $\quad<$ http://www.livrariacultura.com.br/p/o-belo-e-a-fera-1347634 $>$. Acesso em: 19 ago. 2015.

VAN VELTHEM, Lúcia Hussak. Os "originais" e os "importados": referências sobre a apreensão wayana dos bens materiais. INDIANA, p. 141-159 Páginas, 2010.

VELTHEM, Lúcia Hussak. Artes indígenas: notas sobre a lógica dos corpos e dos artefatos. Textos escolhidos de cultura e arte populares, v. 7, n. 1, 2010. Disponível em: $<$ https://repositorio.museu-goeldi.br/bitstream/mgoeldi/319/1/artigo_logica_corpos_versao_e ditor.pdf>. Acesso em: 17 out. 2019.

VIDAL, Lux Boelitz; Guidon, Niede ; Pessis, Anne-Marie ; and Several Others. Grafismo indigena: Estudos de antropologia estetica. First Edition edition. São Paulo, SP: Edusp, 1992. 
VIVEIROS DE CASTRO, Eduardo. A floresta de cristal: notas sobre a ontologia dos espíritos amazônicos. Cadernos de Campo (São Paulo, 1991), v. 15, n. 14-15, p. 319, 2006.

VIVEIROS DE CASTRO, Eduardo. A inconstância da alma selvagem. Edição: 1. [s.1.]: Ubu Editora, 2002.

VIVEIROS DE CASTRO, Eduardo. Metafísicas canibais: Elementos para uma antropolia pós-estrutural. Edição: 1. São Paulo: Ubu Editora, 2018.

WHITEHEAD, Neil L.; ALEMÁN, Stephanie (Orgs.). Anthropologies of Guayana: Cultural Spaces in Northeastern Amazonia. Edição: 2nd ed. [s.1.]: University of Arizona Press, 2016.

WIELS, Geneviève. Dessine-moi... une frontière. [s.1.]: FMC Production, 2004. Disponível em: $\quad<$ http://www.film-documentaire.fr/4DACTION $/$ w fiche film $/ 12780$ 1 $>$. Acesso em: 13 out. 2019.

YANO, Ana Martha Tie. A fisiologia do pensar: corpo e saber entre os Caxinauá. Mestrado em Antropologia Social, Universidade de São Paulo, São Paulo, 2010. Disponível em: $<\underline{\text { http:// }}$ www.teses.usp.br/teses/disponiveis/8/8134/tde-04022010-102959/>. Acesso em: 13 out. 2019. 